\title{
A Drosophila melanogaster ivarvonal- fejlődésében szerepet játszó gének azonosítása és vizsgálata
}

Ph.D. értekezés

Készítette: Henn László Dániel

Témavezető: Dr. Erdélyi Miklós

SZTE Biológia Doktori Iskola

Magyar Tudományos Akadémia, Szegedi Biológiai Kutatóközpont,

Genetikai Intézet

SZTE TTIK

Szeged, 2014 


\section{Tartalomjegyzék}

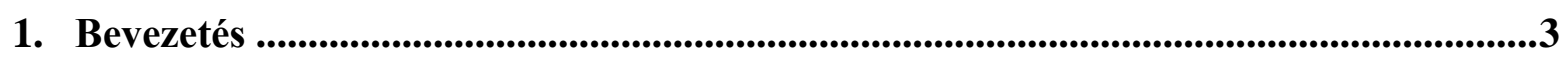

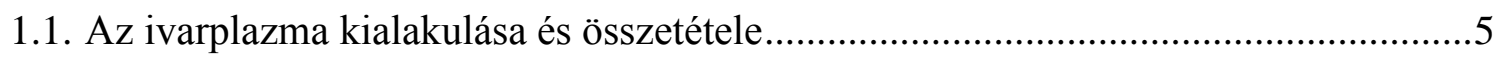

1.2. Az embrionális ivarsejtek kialakulása, fejlődése ................................................... 7

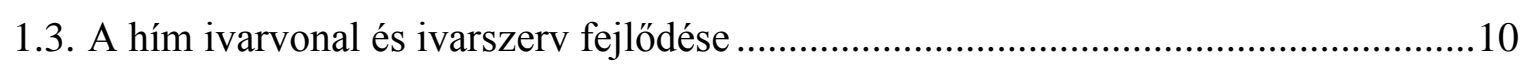

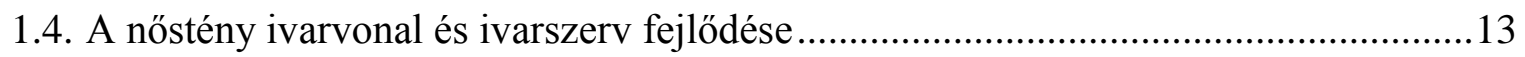

1.5. Az ivarvonalsejtek fejlődéséhez szükséges faktorok azonosítása ecetmuslicában .....17

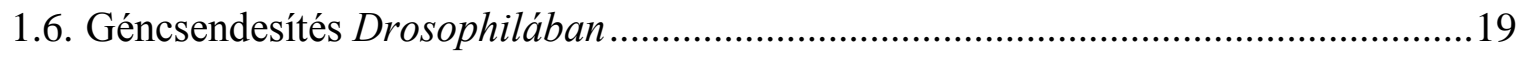

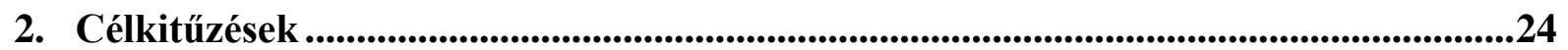

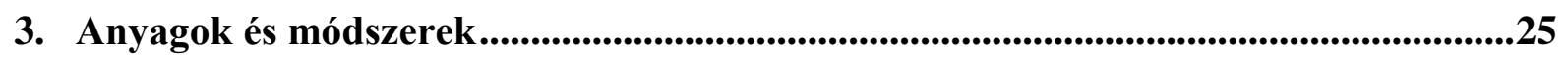

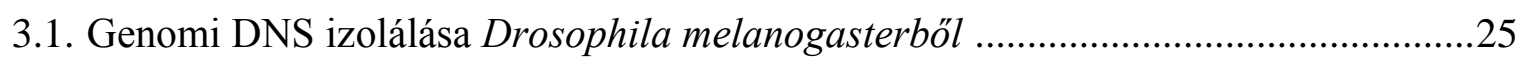

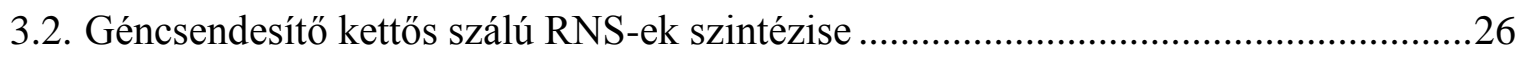

3.3. Géncsendesítés Drosophila embriókban...................................................................27

3.4. Mutáns allélok vizsgálata érzékenyített genetikai háttéren........................................28

3.5. Indirekt immunofluoreszcens jelölés Drosophila embriókon és szerveken ...............29

3.6. Géncsendesítés Drosophila ivarvonalban transzgenikus shRNS-ekkel.......................30

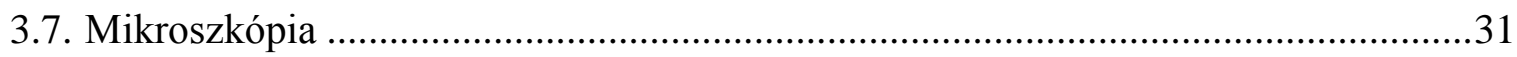

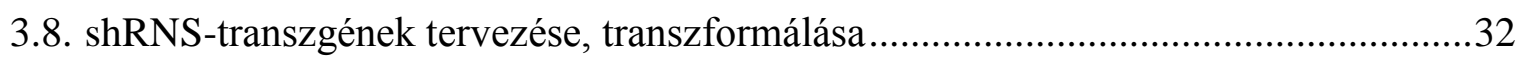

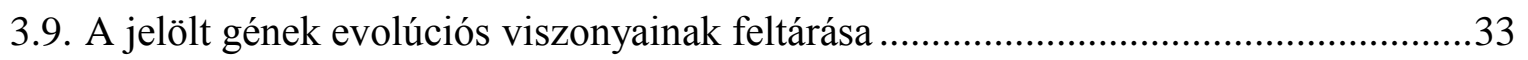

4. Eredmények .....................................................................................................................34

4.1 Az embrionális ivarvonal-specifikus kifejeződést mutató gének

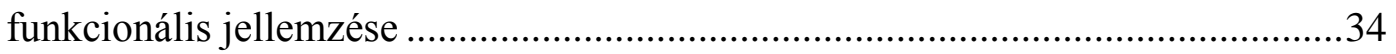

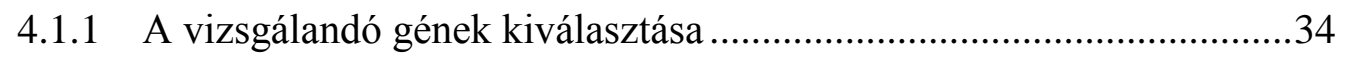

4.1.2 A géncsendesítő kísérletsorozat menete.............................................36

4.1.3 A géncsendesítő kísérletsorozat kontrolljai.........................................36

4.1.4 A géncsendesítő kísérletsorozat eredménye.......................................38

4.1.5 A géncsendesítő kísérletsorozat technikai ismétlése...........................40

4.1.6 A géncsendesítő kísérletsorozat ismétlése új dsRNS-ekkel ................41

4.1.7 Az embrionális ivarsejt-fenotípusok kiértékelése ............................42

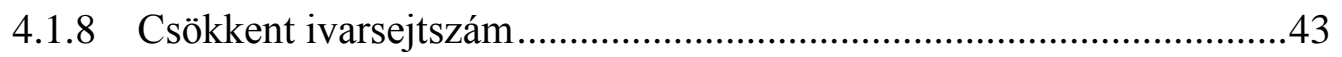

4.1.9 Középbél-kezdeményben maradó ivarsejtek.....................................44

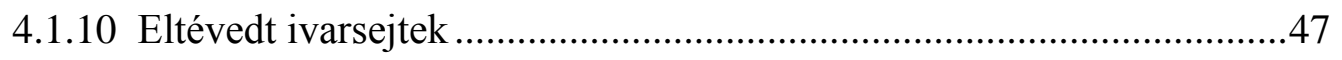

4.1.11 Az embrionális ivarszerv-kezdemény kialakulásának hibája...............48 
4.1.12 Az embrionális ivarszervek hiánya ................................................49

4.1.13 Csökevényes ivarszervek kifejlett állatokban ...................................50

4.1.14 A jelölt gének rendszerezése fenotípusaik alapján...............................51

4.2 Az ivarsejt transzkriptóma redundanciájának vizsgálata .....................................53

4.3 A géncsendesítő kisérletsorozat eredményeinek megerősítése genetika

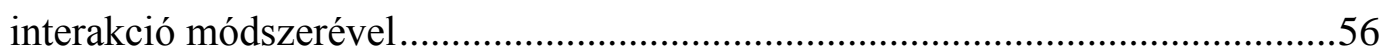

4.4 A jelölt gének evolúciós viszonyainak bemutatása és a génfunkciók jellemzése..62

4.5 Az RNSi kísérletsorozatban azonosított gének szövet-specificitásának

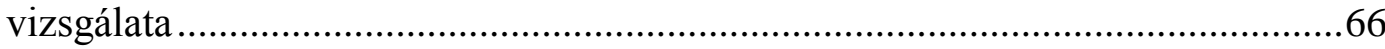

4.5.1 Az ivarvonal-specifikus GAL4-források tesztelése ...........................67

4.5.2 Az ivarvonal-specifikus géncsendesítés jellemzése...........................69

4.5.3 Az ivarvonal-specifikus shRNS alapú géncsendesítéseredménye .......72

4.6 Az RNSi kísérlesorozatban azonosított gének részletes genetikai jellemzése .......78

4.6.1 A feo gén az ivarvonalsejtek osztódásához szükséges .........................78

4.6.2 A pebble gén szerepe az ivarvonal-fejlődésben .................................83

4.6.3 A mei-P26 gén funkciója az embrionális és lárvális ivarvonalban ......85

4.6.4 A szumoiláció szerepe az ivarvonal-fejlődésben ...............................91

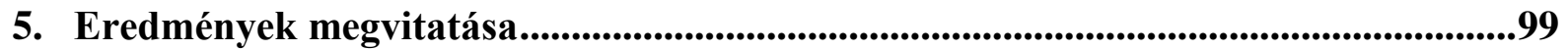

5.1. A Drosophila embrionális ivarsejt-fejlődésének vizsgálata géncsendesítéssel ..........99

5.2. Az ivarsejt transzkriptóma funkcionális redundanciája alacsony szintü......................101

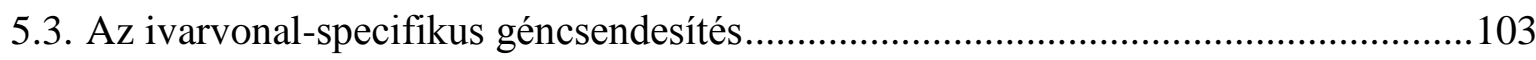

5.4. A Drosophila ivarvonal-fejlődésében szerepet játszó gének evolúciós

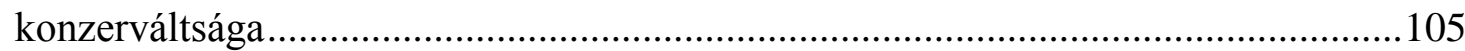

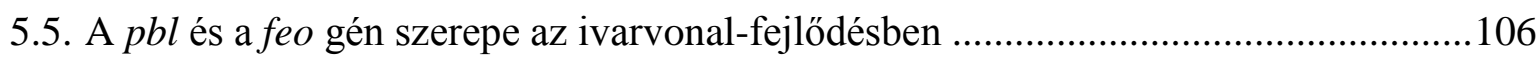

5.6. A mei-P26 az embrionális és lárvális ivarsejtek túléléséért felelős ...........................108

5.7. A szumoiláció szerepet játszik a csíravonal őssejtek fenntartásában

és az ivarvonal differenciálódásában................................................................110

Köszönetnyilvánítás .......................................................................................................113

Irodalomjegyzék ...............................................................................................................................114

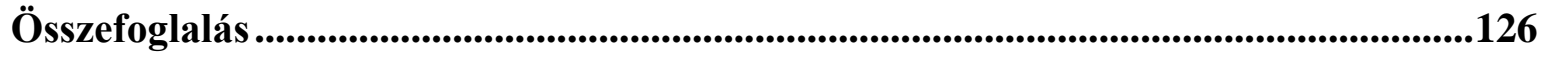

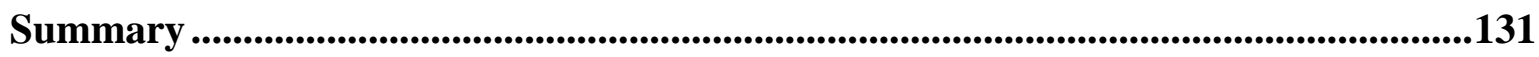

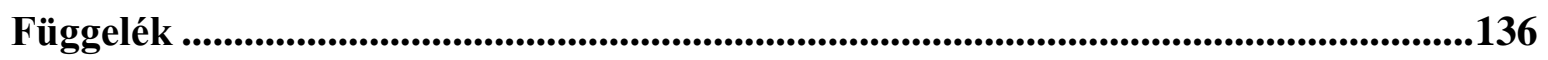




\section{Bevezetés}

A többsejtü eukarióta szervezetek két alapvető sejttípussal rendelkeznek: a szomatikus és az ivarvonal sejtekkel. A szomatikus, vagy testi sejtek az eukarióta szervezetek differenciált szöveteit, szerveit hozzák létre, míg az ivarvonal sejtjeinek feladata a szaporodásért felelős gaméták kialakítása. A gaméták összeolvadása után kialakuló új nemzedék egyedében a szomatikus és ivarvonal sejtek ismét elkülönülnek, ezért az ivarvonal kialakulása és fejlődése generációról-generációra, ciklikusan megismétlődik.

Többsejtü állatokban az ivarvonal kialakulása alapvetően kétféle módon mehet végbe. A preformált típusú ivarvonal-kialakulás esetében már a petesejtben jelen vannak azok a faktorok, amelyek megtermékenyítés után szükségesek a fejlődő embrió ivarvonalának megalapításához (pl. ecetmuslica, laposféreg, karmosbéka) [1]. Az induktív típusú ivarvonal meghatározás esetén a fejlődő embrió el nem köteleződött (totipotens) sejtvonalából indukciós jelek hatására alakul ki az ivarvonal (pl. emlősök) [2]. Habár a többsejtü állatok igencsak eltérő fejlettségű szervezetek csoportjait képviselik, és ivarvonal-meghatározásuk különféle lehet, az ivarvonalsejtek jellegzetességei tekintetében igen hasonlatosak. Amellett, hogy az állati ivarvonal sejtjei morfológiailag is eltérnek az őket körülvevő testi sejtektől (nagyméretü, kerek sejtek), fejlődésükben, müködésükben is jelentős különbségeket mutatnak azoktól. Az embrionális ivarsejtek egyik közös jellemvonása, hogy a testi sejtektől az egyedfejlődés nagyon korai szakaszában elkülönülnek, és génkifejeződésük szempontjából jelentősen különböznek azoktól. Az ivarvonal akár preformált, akár induktív módon alakul ki, jellemző rá, hogy fejlődése korai szakaszában a transzkripció gátolt. Az állati embrionális ivarsejtekre általánosságban jellemző, hogy az ivarszervek szomatikus eredetű sejtjeitől eltérő helyen és időben 
alakulnak ki, és aktív sejtvándorlás során jutnak el azokhoz, hogy kialakítsák az embrionális ivarszerveket. Az utóbbi évtized felismerése, hogy az állati ivarsejtekben kis RNS-ek járulnak hozzá a genom stabilitásához és az ivarvonal-fejlődés szabályozásához. A Piwi fehérjéhez kapcsolódó kis RNS-ek (piRNS) az ugráló genetikai elemek által okozott mutációktól védelmezik az ivarsejtek genomját $[3,4]$. Bizonyos mikroRNS-ek (miRNS) az ivarvonalsejtek fejlődésének szabályozásában vesznek részt. Ez a szabályozás meghatározott célgének poszttranszkripciós génszabályozása által valósul meg. Az ivarvonal fejlődésben szerepet játszó kis RNS útvonalak konzerváltságot mutatnak laposférgekben, ecetmuslicában, emlősökben [5]. Végül az ivarvonalsejtek legnyilvánvalóbb sajátsága, hogy meiózissal képesek létrehozni a haploid hímivarsejtet, vagy a petesejtet. Annak ellenére, hogy az állati ivarsejtek fejlődésük és müködésük szempontjából jelentős hasonlóságot mutatnak, viszonylag kevés ivarsejt-fejlődést irányító evolúciósan konzervált gént fedeztek fel. Fonalférgekben, ecetmuslicában nagyléptékü genetikai vizsgálatokkal az ivarsejtfejlődés számos elemét azonosították, azonban ezek az eredmények korántsem elégségesek ahhoz, hogy az ivarsejtek fejlődéséről teljes képet kapjunk.

A genetikai kísérletekben használt modellszervezetek közül az ecetmuslica (Drosophila melanogaster) az egyik legalkalmasabb az ivarsejtek fejlödésében szerepet játszó gének vizsgálatára. A nagyszámú, könnyedén elérhető mutáns allél, a géncsendesítés technikájának kidolgozottsága, a rendszerezett adatokat tartalmazó biológiai adatbázisok, a kiforrott molekuláris biológiai, biokémiai, bioinformatikai módszerek igen erőteljes technikai hátteret biztosítanak az ivarsejtvonal sejtek differenciálódását feltárni hivatott kísérletekhez. A Drosophila modellszervezet nagy előnye továbbá, hogy az embrionális ivarsejtek fejlődése kiválóan vizsgálható in vivo módon is, jól jellemzett markerek (markermutációk, fluoreszcensen jelölt transzgének, stb.) segítségével. Az ecetmuslica ivarvonal-fejlődés genetikai hátterének vizsgálata 
túlmutat a faj ivarvonal-fejlődésének megismerésén, hiszen ezen összetett folyamat vizsgálata hozzásegíthet olyan általános fejlődésbiológiai jelenségek pontosabb megértéséhez, mint a sejtvándorlás, őssejt-fenntartás és -differenciálódás, vagy például a sejtek közötti kommunikáció. A vizsgált folyamat evolúciósan konzervált elemeinek feltárása pedig hozzájárulhat az ivarvonal-fejlődés konzervált molekuláris mechanizmusainak megismeréséhez.

\subsection{Az ivarplazma kialakulása és összetétele}

A petesejtek a nőstény állatok petefészkeiben keletkeznek, fejlődésük alatt olyan RNS-ek, fehérjék, sejtalkotók halmozódnak fel bennük, melyek a megtermékenyítés után létrejövő embrió fejlődéséhez szükségesek. Ezt a jelenséget anyai hatásnak nevezzük. Amennyiben valamelyik embriófejlődéshez szükséges komponens a petefejlődés során nem, vagy hibásan kerül a petesejtbe, anyai hatású rendellenességről beszélünk, a mutációt pedig, amely ezt a hibát okozza, anyai hatású mutációnak nevezzük, mivel az utód egyed fejlődési hibája nem saját genotípusának, hanem az anyjáénak köszönhető.

A következő generáció ivarvonalának megalapítása tulajdonképpen már a fejlődő petesejtben megkezdődik, ugyanis már a fejlődő petesejt poszterior pólusán speciális citoplazma-részlet, az ún. ivarplazma alakul ki, mely az ivarvonal kialakulásához nélkülözhetetlen, lokalizált mRNS-eket, fehérjéket és sejtszervecskéket tartalmaz [6]. A megtermékenyítést követően, az embrionális fejlődés korai szakaszában, ún. szincíciális blasztoderma stádiumban, az embrió poszterior végén elsőként füződnek le az ivarvonalsejtek, melyek citoplazmája az ivarplazmából keletkezik. Az ivarplazma tartalmazza azokat a faktorokat, melyek meghatározzák ezen sejtek ivarsejt sorsát (1. ábra). A poszterior ivarplazma 
kialakításában kulcsszerepe van az oskar (osk) génnek. Az osk mRNS elöször a petefejlődés során mikrotubulus hálózat irányításával lokalizálódik a poszterior póluson. Kimutatták, hogy az osk gén helyes kifejeződése elengedhetetlen feltétele az ivarplazma, később az ivarsejtek kialakulásának [7]. Számos olyan gént azonosítottak melyek az osk mRNS poszterior pólusra való szállításáért (pl. orb, yps), megfelelő helyspecifikus transzlációjáért (pl. arrest, apontic, Bicaudal C, staufen, vasa), az Osk fehérje poszterior póluson történő kihorgonyzódásért (Tropomyosin II, moesin) felelősek [8-10].

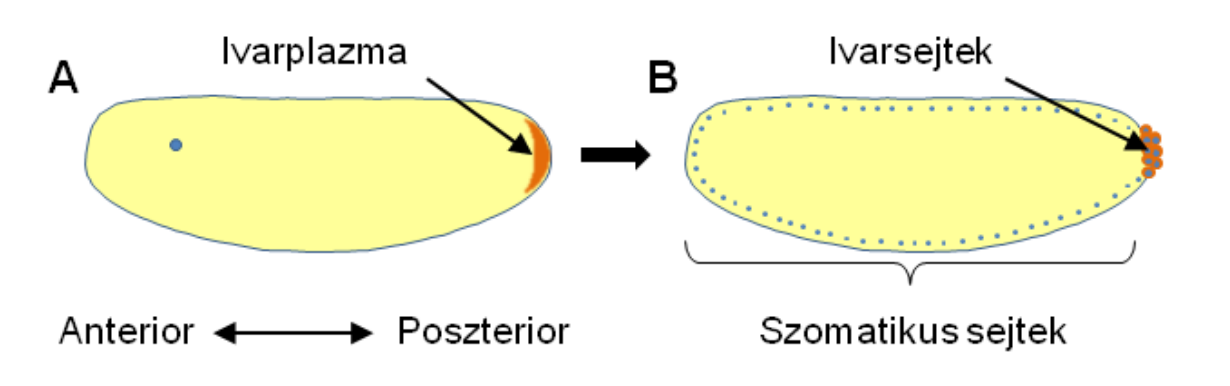

1. ábra: Ivarsejtek lefüződése az embrió poszterior pólusán. A: Az ecetmuslica peték poszterior pólusukon speciális citoplazmarészletet, ivarplazmát hordoznak (narancssárga). B: A fejlődő embriókban a poszterior póluson elsőként lefüződő ivarsejtek citoplazmája ebből az anyagból áll, míg a leendő szomatikus sejtek citoplazmája ivarplazmát nem tartalmaz.

Az ivarplazmában mitokondriumokkal gyakran asszociált elektrondenz szemcsék, az úgynevezett poláris szemcsék találhatók, melyek lokalizált fehérjéket és RNS-eket tartalmaznak. A poláris szemcsékhez hasonló struktúrákat az embrionális ivarvonalsejtekben is találunk, ami arra enged következtetni, hogy ezek a komponensek az ivarsejtek fejlődéséhez, müködéséhez, fennmaradásához szükségesek [11]. Számos esetben kimutatták, hogy azon gének, melyek RNS terméke az ivarplazmában dúsul fel, szerepet játszanak az utódok ivarsejt-fejlődésben. Mivel az embrionális ivarsejtek transzkripciója sokáig represszált állapotú, érthető, hogy az ivarsejtek kialakulásához szükséges faktoroknak szükségszerűen az anyaállattól kell 
származniuk [12]. Mivel e faktorokat kódoló gének mutációi az utódok életképességét nem befolyásolják, ellenben azok sterilitását okozzák, az ilyen típusú mutációkat „grandchild-less” fenotípust okozó mutációknak nevezzük.

\subsection{Az embrionális ivarsejtek kialakulása, fejlődése}

A frissen lefüződő embrionális ivarsejtek mindegyike legfeljebb két aszinkron osztódáson megy keresztül, így átlagosan 35 ivarvonalsejtet jön létre (2.A ábra). Az embrió fejlődésének harmadik órájában az ivarsejtek a mitotikus sejtciklus $G_{2}$ fázisában leállnak, és a sejtciklust lárvális korig nem is folytatják. Az embrionális ivarsejtek az alattuk elhelyezkedő poszterior középbél-kezdemény sejtrétegéhez kapcsoltan a 7. stádiumban az embrió belsejébe türemkednek (2.B ábra), és a 9-10. stádiumig a bélkezdemény üregében csoportosulnak. Ezután az embrionális ivarsejtek aktív mozgással áttörnek a bélkezdemény falán (2.C ábra). A poszterior középbél sejtjei között ilyenkor felnyílnak az apikális kapcsolatok, és rések keletkeznek a sejtek között [13]. Az ivarsejtek bélfalon való áthaladásához a Trapped in endoderm-1 (Tre1) G-fehérje kapcsolt receptor szükséges. Ennek hiányában az ivarsejtek nem képesek áthaladni az epitéliumon, és a bélkezdeményben rekednek $[14,15]$. A bélfalon való áthatolás folyamatában taszító szignáloknak is szerepe van, például a zigotikusan kifejeződő wunen és wunen-2 redundánsan ható gének a bélfal ventrális epitéliumában fejeződnek ki. Hiányukban az ivarsejtek nem lépnek ki a bélből a dorzális oldalon $[16,17]$. 
A

Ivarsejtek

kialakulása

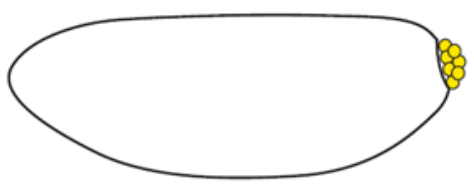

5. stádium ( 2,5 óra $)$

\section{B}

Ivarsejtek kapcsolódása a középbélkezdemény falához, betüremkedés

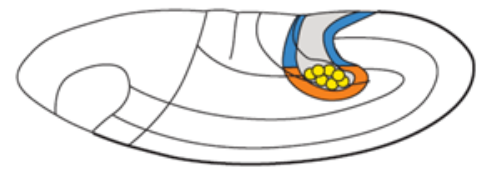

8. stádium ( 3,5 óra)

C

A középbél epitéliumon való átkelés iniciációja

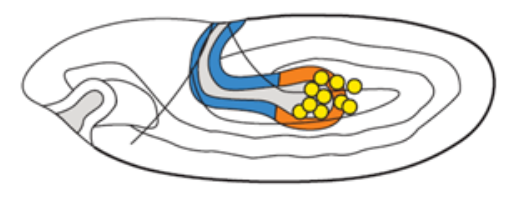

9-10. stádium ( 4,5 óra)

D Átkelés a középbél epitéliumán

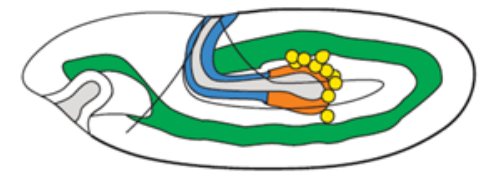

10. stádium ( $~ 5$ óra)

\section{E}

Ivarsejtek két csoportra osztódása és vándorlása a mezoderma felé

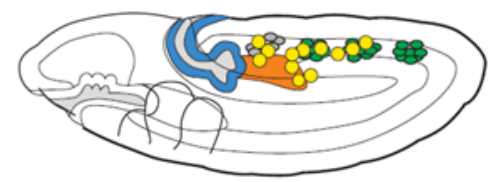

11. stádium ( 7 óra)

\section{F}

Egyesülés a gonád mezodermával

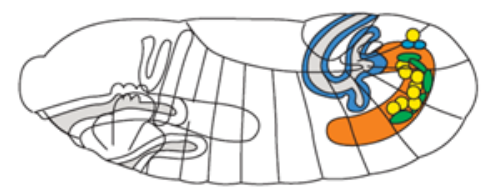

12. stádium ( 9 óra)

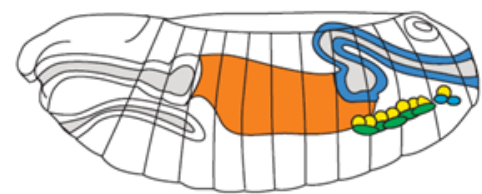

13. stádium ( 10,5 óra)

Ivarvonal-szóma összerendeződés

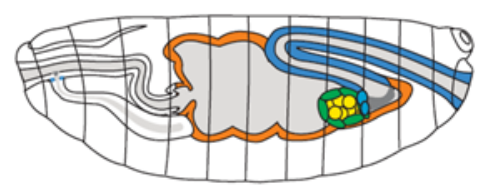

14. stádium ( 11,5 óra)

Embrionális ivarszervek kialakulása

\section{OEmbrionálisivarsejtek $\square$ Utóbél $\square$ Középbél $\square$ Mezoderma}

2. ábra: Embrionális ivarsejtek vándorlása Drosophilában Bal oldali oszlopban az ivarsejt vándorlás lépései, a jobb oldali oszlopban a megfelelő embrionális fejlődési stádiumok, és a petelerakástól számított hozzávetőleges idő $25^{\circ} \mathrm{C}$-on [18]. 
Az embrionális ivarvonalsejtek a bélkezdemény üregében alakváltozáson mennek keresztül, morfológiájuk polarizálttá válik, magvaik a bélfal felé irányulnak, farki végük egymás felé mutat. Ekkor felbomlik az ivarsejtek csoportja, és a sejtek amőboid alakot felvéve, egyesével átkelnek a bélfalon [17]. Ezt követően az ivarsejtek a jobb-bal szimmetriának megfelelően két csoportra oszlanak a mezodermában, és az embrió dorzális oldala felé vándorolnak (2.D-E ábra). Ezért a vándorlásért egy vonzó szignál felelős, melynek szintézisét a 3-hidroxi 3-metilglutaril koenzim A reduktáz (Hmgcr) végzi [19]. Kimutatták, hogy az embrió középvonalában maradó ivarsejtek nem-apoptotikus sejthalállal eliminálódnak. Ez a folyamat szintén wunen és wunen-2 függő, tehát ezen géneknek szerepe az ivarsejtvándorlásban többrétü [20]. A két csoportra oszlott ivarsejtek a mezodermában történő vándorlásuk során a szomatikus gonád prekurzor sejtekhez kapcsolódnak (2.F ábra) az embrionális fejlődés 13. stádiumában, majd a 14. stádiumban kialakulnak a 10-15 ivarsejtet tartalmazó gonádok az 5. potrohszelvény területén (2.G-H ábra).

Az ivarszervek nemmeghatározása az embrionális fejlődés során, az embrionális ivarszervek kialakulása alatt megy végbe. Nemek között génexpressziós különbségeket ekkor figyelhetők meg először [21]. Az ivarvonal szexdeterminációja összetett folyamat, mely függ az ivarszerv szomatikus alkotóinak nemi identitásától (nem autonóm identitás) és az ivarszervbe integrálódó ivarsejtek kromoszómális nemétől (autonóm szexuális identitás) [22,23]. Mindkét sejttípusban az Xkromoszómák-autoszómák aránya határozza meg a sejtek nemi identitását.

Az emlősökkel ellentétben a Drosophila Y-kromoszóma jelenléte, vagy hiánya a nemi jellegeket nem, csak a hím egyedek fertilitását befolyásolja, mert hordoz néhány spermiogenezisben szerepet játszó, a herében kifejeződő gént [24,25]. 


\subsection{A hím ivarvonal és ivarszerv fejlődése}

A hím ivarszervekben az ivarsejtek differenciálódása az embrió-lárva fejlődési átmenet során kezdődik el. Ekkor a herekezdemény csúcsi részében elhelyezkedő ivarvonalsejtek a szomatikus eredetü ún. hubsejtekhez egy gap junction fehérjén (Zero poulation growth, Zpg) keresztül kapcsolódnak. A hubsejtek speciális celluláris mikrokörnyezetet, ún. niche-t biztosítanak a hozzájuk kapcsolódó ivarvonalsejtek számára azzal, hogy a BMP (Bone morphogenic protein) útvonal szolúbilis ligandjait, a Decapentaplegic (Dpp) és Glass bottom boat (Gbb) fehérjéket termelik. Ezek a ligandok a hubsejtekhez kapcsolódó ivarsejtekben aktiválják a BMP jelátviteli útvonalat, ami a sejteket megvédi a differenciálódástól, fenntartva a sejtek őssejt jellegét [26]. A niche-ben elhelyezkedő, őssejt jellegü ivarvonalsejteket csíravonal őssejteknek nevezzük. Mindegyik csíravonal őssejtet 2-2 szomatikus ciszta őssejt öleli körül (3.A ábra). A csíravonal őssejtek aszimmetrikus osztódása során kétféle sejttípus jön létre. A hubsejtekkel fizikai kapcsolatban maradó utódsejt megőrzi őssejt jellegét, a hubsejtektől eltávolodó leánysejt, a goniálblaszt azonban a differenciálódás útjára lép, hiszen a BMP ligandok forrásától eltávolodva, azok differenciálódást gátló hatása alól felszabadul. A goniálblaszt sejtekben BMP útvonal kikapcsolódásával válik lehetővé az ivarvonal differenciálósához szükséges bag of marbles (bam) és benign gonial cell neoplasm (bgcn) gének átíródása [26]. Az ivarvonalsejtekkel párhuzamosan a cisztaőssejtek is osztódnak, így a goniálblasztokat is 2-2, immár cisztasejtnek nevezett szomatikus sejt öleli körül [27]. A korai cisztasejtek markere a sejtmagi lokalizációt mutató Traffic jam (Tj) transzkripciós faktor [28]. 

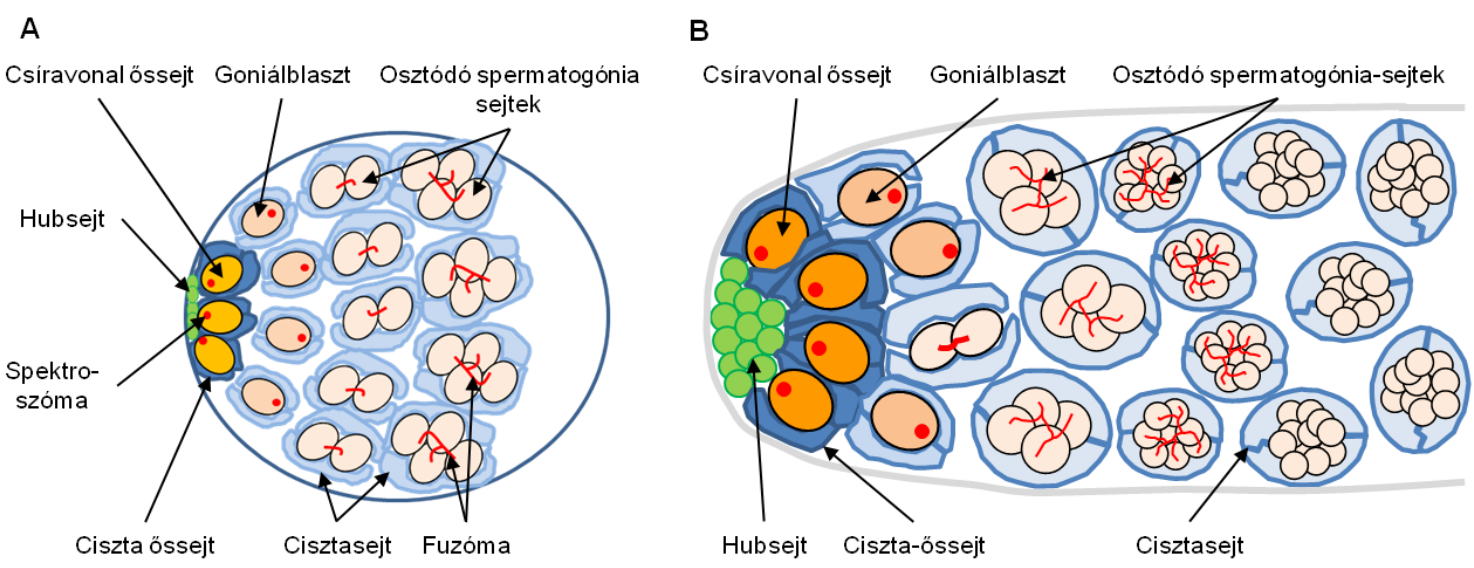

3. ábra: A lárvális here és a kifejlett here csúcsának szerkezete. A: A korai lárvális herében kezdődik meg az ivarvonalsejtek differenciálódása. A here csúcsi részén elhelyezkedő szomatikus eredetü hubsejtekhez csíravonal őssejtek és ciszta össejtek kapcsolódnak. Az elöbbiek goniálblasztokat, az utóbbiak cisztasejteket hoznak létre aszimmetrikus osztódással. A csíravonal össejteket és goniálblasztokat gömbszerű spekroszómák jellemzik. A goniálblasztok további osztódásokkal 4, 8, végül 16 sejtes cisztákat hoznak létre, melyek a spektroszóma eredetü, elágazó fuzómákkal jellemezhetőek. A ciszta őssejtek leánysejtjei a cisztasejtek, amelyek a differenciálódó goniálblaszt sejteket ölelik körül. B: A kifejlett állatok heréjének csúcsi része a lárvális here szerkezetéhez hasonló, és a sejttípusai tekintetében azzal megegyezik.

A csíravonal össejteket és goniálblasztokat speciális sejtszervecske az ún. spektroszóma jellemzi. A spektroszómák a mitotikus orsók kihorgonyzásához és az aszimmetrikus osztódáshoz szükségesek [29]. A spektroszóma elhelyezkedése alapján a csíravonal őssejtek és goniálblaszt sejtek jól elkülöníthetők. A spektroszóma a csíravonal őssejtekben jellegzetesen a citoplazma anterior, a hubsejtek felőli oldalán figyelhető meg, míg a goniálblasztokban a spektroszóma elhelyezkedésre nem jellemző az anterior lokalizáció (3.A ábra). A lárvális herefejlödés korai szakaszában folytatódik az ivarvonal differenciálódása. A goniálblasztok négy egymást követő mitotikus osztódáson mennek keresztül, melynek eredményeként 16 sejtes spermatogónium jön létre. A spermatogónium sejtjei, melyeket ekkor elsődleges spermatocitáknak nevezünk, az inkomplett osztódások során nem különülnek el teljesen egymástól, és citoplazmahidak kapcsolják össze azokat. A citoplazmahidakon keresztül a spektroszóma eredetű, elágazó szerkezetủ fuzómák nyúlnak át. Az 
ivarvonal sejtjeinek osztódásait nem követi a szomatikus cisztasejtek osztódása, így a többsejtes cisztákat, a goniálblasztokhoz hasonlóan 2-2 cisztasejt öleli körül (3.A ábra).

A bábkori fejlődés során az ivarszerv szomatikus szövetei intenzíven fejlődnek, kialakulnak a kifejlett állat heréjét jellemző struktúrák, a szeminális vezikulum, járulékos mirigy és az ejakulációs vezeték (4. ábra). A báb és kifejlett állatok ivarszervében a korai spermatociták intenzív sejtnövekedést követően belépnek a meiózisba. A meiózis során cisztánként 64 spermatid keletkezik, melyek megnyúlásával, individualizálódásával és feltekeredésével jönnek létre a megtermékenyítésre kész spermiumok [30]. A kifejlett állatok heréjének csúcsi részének felépítése tulajdonképpen megegyezik a lárvális herével, a csíravonal őssejtek felől az ivarsejtek utánpótlása folyamatos (3.B ábra).

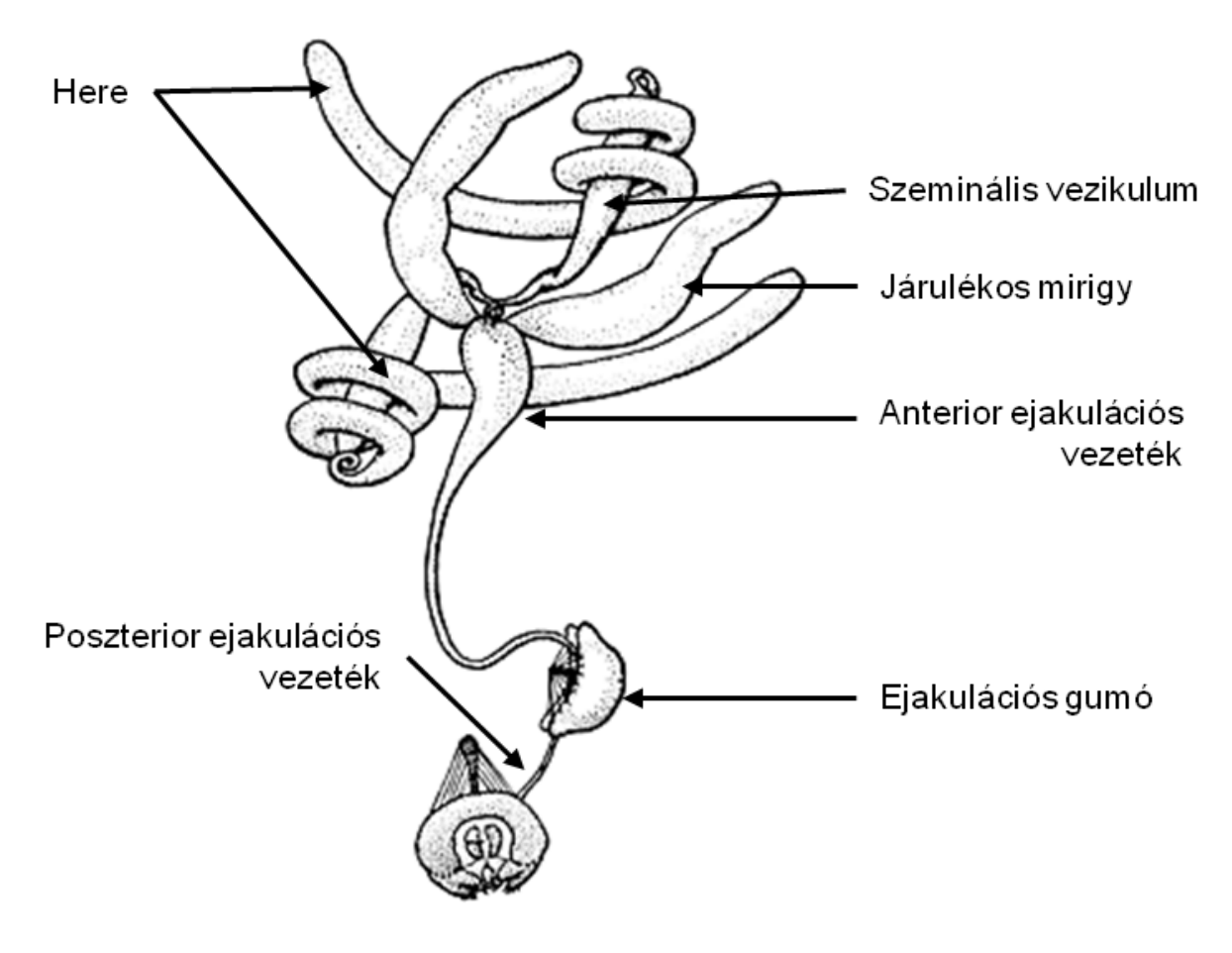

4. ábra: Kifejlett hím Drosophila szaporító-szervrendszere. [30] 


\subsection{A nőstény ivarvonal és ivarszerv fejlődése}

Az embrionális ivarszerv-kialakulás után a nőstény és hím ivarvonal sejtjeinek, illetve az ivarszervek fejlődése némileg eltérően zajlik, az ivarvonal differenciálódásában azonban párhuzamok is felfedezhetőek. A lárvális élet alatt a petefészek folyamatosan növekszik. A kezdetben 10-15 ivarsejtet tartalmazó lárvális petefészkekben a differenciálatlan ivarsejtek lárva stádiumonként átlagosan egyszer osztódnak, így a harmadik lárva stádium végén a petefészek mintegy száz ivarsejtet tartalmaz [31]. A lárvális ivarsszervekben az ivarvonal differenciálódása még nem kezdődik meg, ezért még a harmadik stádiumú lárvák petefészkében is csak differenciálatlan, őssejt jellegü ivarvonalsejtek találhatók. A lárvális ivarszervben szomatikus eredetű sejtek is jelen vannak: a késöbbi terminális filamentumokat kialakító sejtek, a here hubsejtjeivel analóg funkciót betöltő sapkasejtek, valamint az ún. közbeékelődő sejtek, amelyekből a petefészek bizonyos sejtvonalai (kísérősejtek, follikuláris sejtek) differenciálódnak (5. ábra). Ez utóbbiak markere, a here korai cisztasejtjeihez hasonlóan, a Tj transzkripciós faktor.

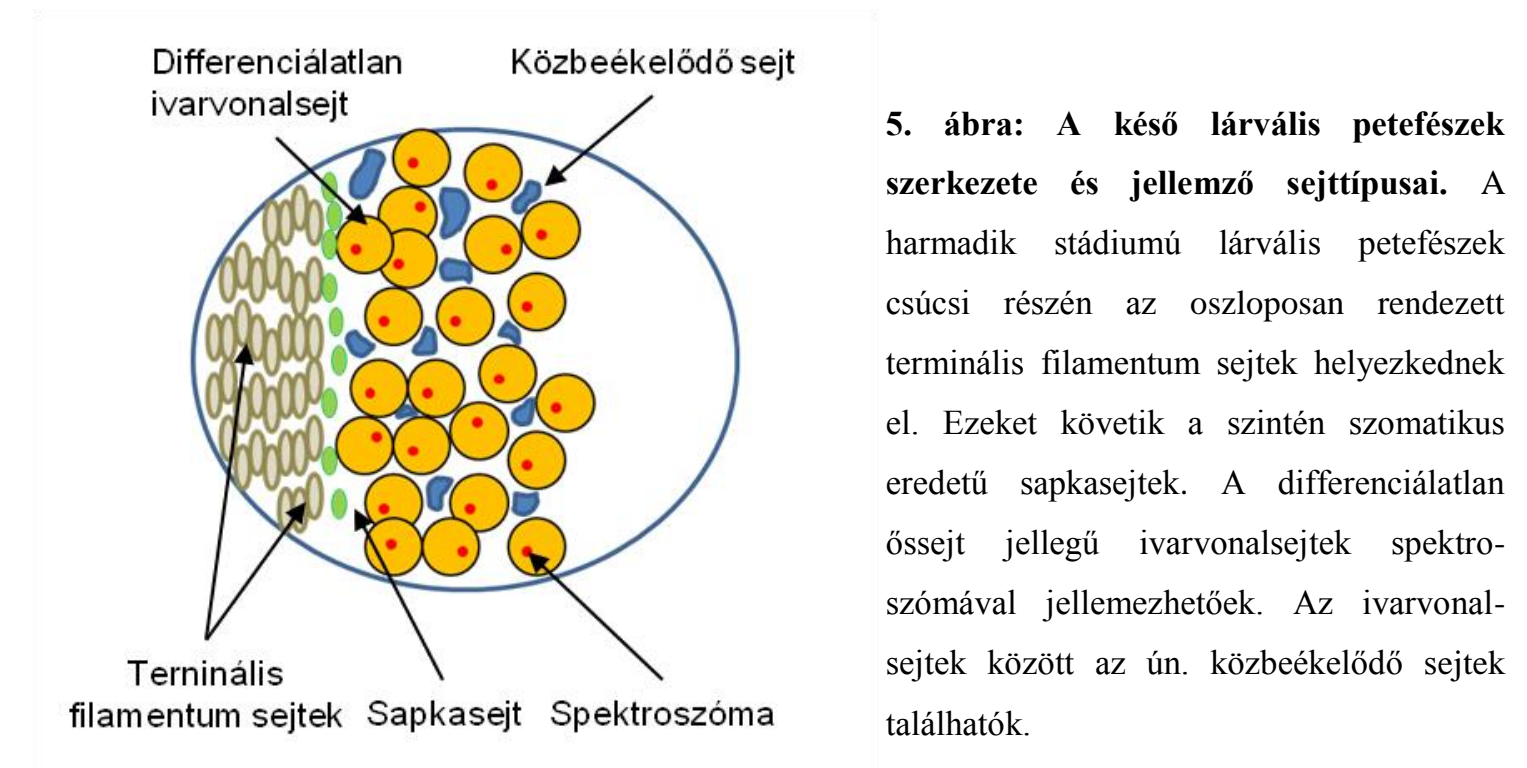


Az ivarszerv és vele együtt az ivarvonal differenciálódása a bábkor elején kezdődik el. A folyamat során a genitális diszkusz a lárvális izmokhoz kapcsolódik, és kialakulnak a traheális és idegi kapcsolatok is. Ezt követi a genitális vezetékek (petecsövek) és a járulékos struktúrák kifejlődése [32]. A petefészkek kifejlett állatokban 16-20 párhuzamos lefutású petecsőből állnak, melynek anterior végén helyezkedik el a germárium, ahol a csíravonal őssejtek differenciálódása zajlik (6. ábra). A petecsövekben történik a petekezdemények fejlődése. Simaizmok biztosítják az egyre fejlettebb petekezdemények továbbhaladását a petecsövek poszterior vége felé, ahol az érett peték a petevezetékbe kerülnek

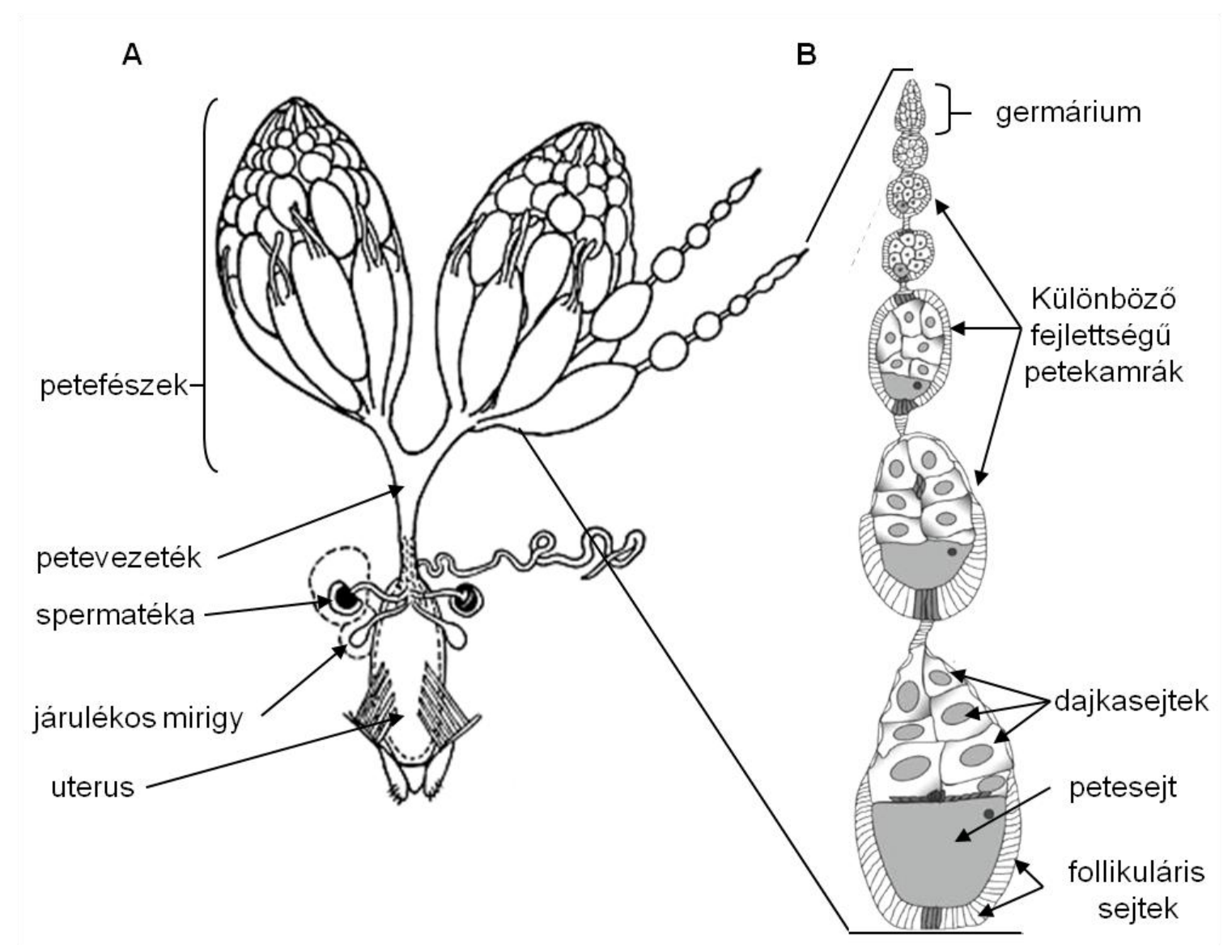

6. ábra: Nőstény Drosophila szaporító szervrendszere (a) és a petecső szerkezete (b) [33,34]

A germárium csúcsi részén szorosan kapcsolódó, oszloposan rendezett 8-10 terminális filamentum sejt helyezkedik el. A terminális filamentum disztális végéhez 
rozettaszerüen közvetlenül kapcsolódik 5-7, szintén szomatikus eredetü sapkasejt (7. ábra). A sapkasejtek a hím ivarszervben található hubsejtekkel analóg funkciót töltenek be, a BMP jelátviteli útvonal szolúbilis ligandjait termelik. A sapkasejtekhez közvetlenül kapcsolodó csíravonal össejtekben a BMP jelátviteli út aktív, ezért azok differenciálódása gátolt. A heréhez hasonlóan, a germáriumban is a csíravonal őssejtek aszimmetrikus osztódással egyszerre újítják meg önmagukat, és hoznak létre differenciálódásra képes leánysejteket, melyeket a nőstények esetében cisztoblasztoknak nevezünk. A cisztoblasztok a csíravonal őssejtek osztódása során távol kerülnek a sapkasejtektől, ezért bennük nem érvényesül a BMP jelátviteli út differenciálódást gátló hatása [35,36].

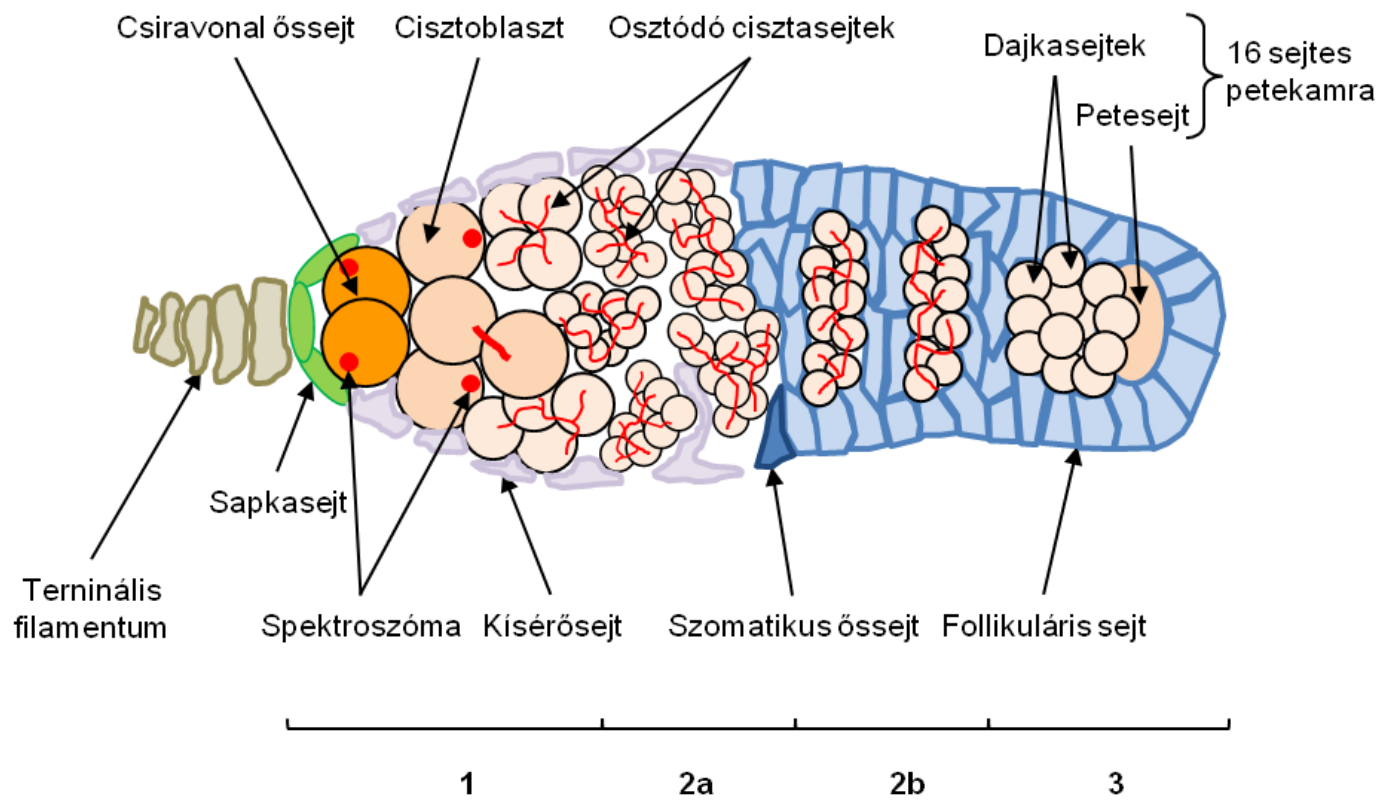

7. ábra: A Drosophila germárium felépítése. A germárium 1. régiójában csíravonal őssejtek cisztasejtekké történő differenciálódása zajlik. A csíravonal őssejtek aszimmetrikus osztódással cisztoblasztokat hoznak létre, melyekböl szimmetrikus osztódásokkal cisztasejtek keletkeznek. A csíravonal őssejteket és cisztoblasztokat spektroszómák, míg a cisztasejteket fuzómák jellemzik. A 2a régióban olyan 16 sejtes ciszták helyezkednek el, amelyeket még nem vettek körül a follikuláris sejtek, míg a 2 b régióban ez már megtörténik. A germárium 3. régiójában olyan, follikuláris sejtekkel burkolt, 16 sejtes ciszta található, melyben a fejlődő petesejt és a dajkasejtek elkülöníthetők. 
Csakúgy, mint a hím ivarvonalban, a germáriumban elhelyezkedő csíravonal őssejtek és a differenciálódásra kész leánysejtek egy jellegzetes sejtalkotóval, a spektoszómával jellemezhetők. A csíravonal őssejtekben a spektroszómák jellegzetesen a sapkasejtek felé néznek, míg a cisztoblasztokat a spektroszómák eme jellegzetes elhelyezkedése nem jellemzi (7. ábra).

Az ivarvonal további differenciálódása során a citoblasztok osztódásával cisztasejtek jönnek létre, melyek több szinkronizált osztódással 16 sejtes cisztát hoznak létre (7. ábra). A cisztasejt-osztódásokat nem követi komplett citokinézis, és az egyes cisztasejtek citoplazmáját gyürücsatornák kötik össze, melyeken a spektroszómákból származtatható elágazó fuzómák ívelnek át (7. ábra). A szomatikus eredetủ kísérősejtek feladata az ivarvonal sejtek differenciálódásának segítése [37]. A 16 sejtes cisztákat a germárium 2 b régiójában a szomatikus őssejtekből származó follikuláris sejtek ölelik körül, melyeknek fontos szerepe van a petekezdemény fejlődésében, a pete szimmetriaviszonyainak kialakításában, továbbá a peteburkok (korion és vitellin) szintézisében (7. ábra). A germárium 3. régiójában az egyik kitüntetett cisztasejt petesejtté, míg a maradék 15 cisztasejt dajkasejtté differenciálódik [24]. A fejlődő petekezdemény a petecsövet körbefonó izomsejtek segítségével lefüződik, és a petecső disztális irányába tolódik [38]. Ily módon, a petecsőben a petevezeték felé haladva egyre fejlettebb petekamrák követik egymást, melyeket a follikuláris sejtekből álló kocsányok kapcsolnak össze.

Az oogenezis során, miközben a follikuláris sejtekkel burkolt 16 sejtes petekezdemény továbbhalad a petecsőben, jellegzetes módon fejlődik. A fejlődés során a dajkasejtek endoreplikálódnak, intenzív mRNS, fehérje és sejtszervecske (Golgi készülékek, mitokondriumok, riboszómák) szintézisbe kezdenek, majd citoplazma tartalmukat a fejlődő petesejtbe ürítik. Miután a dajkasejtek funkciójukat ellátták, a petekezdemény-fejlődés késői szakaszában apoptózissal elpusztulnak. A 
petekezdemény fejlődése során a petesejtben kialakulnak a leendő embrió fejlődését meghatározó anterior-poszterior és dorzális-ventrális testtengelyek, melyben fontos szerepe van a petekezdeményt burkoló follikuláris sejteknek is [30]. A testtengelyek kialakulásával párhuzamosan a poszterior póluson az ivarplazma összeszerelődése is végbemegy, amely feltétele az utód ivarvonala kialakulásának [39]. A nőstény Drosophila ivarvonal sejtjeinek meiózisa a germárium 2a régiójában megkezdődik [40], és a sejtek a profázis diplotén szakaszáig jutnak el. A meiózis a petefejlődés végén folytatódik, ekkor a sejtek a metafázis I-ig jutnak el [41]. A meiózis befejezése a peteaktiváció folyamán történik meg, amikor a petesejt áthalad a petevezetéken [42].

\subsection{Az ivarvonalsejtek fejlődéséhez szükséges faktorok azonosítása ecetmuslicában}

Az ivarsejtek kialakulásában és fejlődében részt vevő gének azonosítására számos kísérletsorozatot végeztek. Számos gént azonosítottak, melyek az érett petesejtek kifejlődéséhez, helyes szimmetriaviszonyok kialakításához szükségesek. E géneket jórészt az úgynevezett nőstény steril mutációk segítségével azonosították. E mutációk ugyanis jelentősen nem befolyásolják az anyaállat életképességét, ám a petefejlődés hibát szenved. Nőstény steril allélokat eredményeznek még azok az anyai hatású gének mutációi is, mely gének termékei, az anyaállat dajkasejtjeiből származnak, és a korai embriogeneishez szükségesek. A mutagenezis kísérletek fénykorában számos nősténysteril allélt azonosítottak, melyekről bizonyították, hogy a pete kialakulásához, vagy az embrió fejlődéséhez szükséges géneket érintenek [4345]. Ehhez hasonlóan, hímsteril allélok segítségével a hímivarsejtek fejlődéséhez szükséges gének azonosíthatók [46]. 
Az ecetmuslica embrionális ivarvonalsejtjeinek kialakulását és korai fejlődését anyai hatású gének irányítják, melyeket a „grandchildless” azaz „unokátlan” fenotípust okozó mutációkkal azonosítottak [47]. Ezen anyai hatású mutációk hatására ugyanis az utódok bár életképesek, de ivarsejteket nem hoznak létre, végül is a mutáns nőstény utódai sterilek lesznek. Az „unokátlan” fenotípust okozó allélok hatása felerősíthető genetikailag érzékenyített háttéren [48,49]. Mutagenezis kísérletek segítségével már az ivarsejt-vándorlás és sejthalálért felelős gének azonosítását megkezdték [50]. Azokat a mutagenezisen alapuló módszereket, melyeknek célja egy adott fenotípusért felelős gének azonosítása, forward, vagy klasszikus genetikai módszereknek nevezzük.

Az ivarsejt-fejlődést irányító faktorok megismerésének másik útját a reverz genetikai módszerek jelentik. Ezekkel a vizsgálatokkal, bizonyos szempontok alapján (például génszekvencia vagy génkifejeződési mintázat) kiválasztott génekhez kívánnak fenotípust rendelni. A Drosophila ivarsejt-fejlődés vizsgálatánál a reverz genetikai vizsgálat kiindulási pontját képezhetik az ivarsejtekben kifejeződő gének. A nagyléptékü RNS-lokalizációs adatbázisokból például kiválogathatók azok a gének, melyek RNS-terméke az embriogenezis folyamán az ivarvonalban fejeződik ki [51,52]. Korai embriók poszterior pólus RNS összetételének ismerete is felvilágosítást adhat az ivarplazma komponenseiröl [53]. Embrionális ivarszerv-kezdeményekből készített cDNS-gyüjtemény (cDNS: komplementer DNS, mRNS-sé átíródó DNS szekvencia) is kiindulópontul szolgálhat reverz genetikai kísérletekhez [54]. A microarray technika lehetővé teszi, hogy egyes szövetek, sejtféleségek RNStartalmában különbségeket mutassunk ki. Kutatócsoportunk egy korábbi munkája során, az ivarplazmában feldúsuló mRNS-ű gének azonosítása érdekében, ivarplazmahiányos és ektopikus ivarplazmát hordozó peték RNS-tartalmát hasonlította össze microarray kísérletben [55]. 
A gének funkcióit legtöbbször funkcióvesztést előidéző genetikai eljárásokkal vizsgáljuk. A funkcióvesztéses állapot elméletileg előidézhető mutációkkal, mRNS-ek eliminálásával (RNS-interferencia, géncsendesítés), illetve fehérjék inaktiválásával, degradálásával. A technikai okok miatt genetikai kísérletek végrehajtására főként az első két módszert használható.

\subsection{Géncsendesítés Drosophilában}

A géncsendesítés egy évtizedes múltra visszatekintő, funkció vesztést előidéző reverz genetikai módszer, mely egy endogén, kettős szálú RNS-t (dsRNS) bontó enzimkomplex müködésén alapul. Ez az enzimkomplex a dsRNS-t 21 nukleotidos, kis interferáló RNS (siRNS) darabokra hasítja. Az siRNS-ek az Ago2-RISC (RNAInduced Silencing Complex) fehérjekomplexbe töltődnek, amely elhasítja az siRNSekkel komplementer mRNS molekulákat (8.A ábra). Az eredetileg Caenorhabditis elegansban kifejlesztett, RNS interferencián (RNSi) alapuló géncsendesítés hamar elterjedt a Drosophila genetikában is funkcióvesztéses fenotípusok létrehozására, hiszen a genomszekvencia ismeretében szinte bármelyik génre lehet specifikus, géncsendesítő RNS-t előállítani. A géncsendesítések során előfordulhat, hogy a hogy a specifikusnak vélt géncsendesítő RNS-ek nem csak a célgén mRNS-ének mennyiségét csökkentik le. Ez az ún. off-target hatás egyrészt annak tudható be, hogy a hosszú dsRNS-ek feldarabolódása sokféle siRNS-t eredményez, és ezek némelyike más gén mRNS-ével komplemeter lehet. Előfordul azonban az is, hogy egy siRNSnem csak a vele teljesen komplementer mRNS-t képes csendesíteni, hanem az a hozzá nagymértékben hasonlót is (néhány nukleotidos eltérés a komplementer szekvenciában). 
Drosophilában az RNS interferencián alapuló géncsendesítésnek többféle módszerét dolgozták ki. Sejttenyészetek tápoldatához keverve a dsRNS nagy hatékonysággal kifejti géncsendesítő hatását [56]. A dsRNS alapú géncsendesítést azonban élő állatokban is lehet alkalmazni. Ennek elterjedt módja, hogy hajtüszerü másodlagos szerkezetü dsRNS-t kódoló hosszú fordított ismétlődést tartalmazó DNSszekvenciát fejeztetnek ki, mely (long haipin RNS). Az expressziót legtöbbször a GAL4/UAS alapú indukálható expressziós rendszerrel valósítják meg. A módszer nagy előnye, hogy megfelelő promóterrel ellátott transzgenikus GAL4-forrás használatával egy adott gén UAS szabályozó elemmel ellátott géncsendesítő szekvenciája tetszőleges helyen és időben fejeztethetőki [57]. Mára a legtöbb gén UAS-dsRNS konstruktját inszertálták a Drosophila genomba, ezek a transzgenikus vonalak törzsközpontokból elérhetőek [58]. A Drosophila ivarsejtekben azonban speciális géncsendesítő eljárásokra van szükség. A törzsgyüjteményekből elérhető UAS-dsRNS transzgének többségét UASt elemmel látták el, ami a $H s p 70$ gén promóterét tartalmazza. Az így kialakított konstrukciók a tapasztalatok szerint ivarsejtvonal sejtekben nem, vagy alig müködiknek. Vannak azonban arra utaló adatok, hogy az ivarvonalban túltermeltetett Dicer-2 fokozhatja az UASt enhanszerrel ellátott transzgén kifejeződését [59,60]. A transzgenikus géncsendesítő transzgének másik típusát a mesterséges miRNS-ek, másnéven short hairpin-RNS-ek (shRNS-ek) képviselik. Ebben az esetben a transzgének olyan, elöre megtervezett miRNS-eket kódolnak, melyek tetszőleges célgént képesek csendesíteni (8.B ábra). Újabban elérhetők olyan mikro-RNS (miRNS) útvonalon ható shRNS transzgének, melyeket UASp elemmel látták el, amely a P-elem transzpozáz promóterét tartalmazza [61]. A P-transzpozáz promóter alapú konstrukciók az ivarvonalban erős expressziót biztosítanak [62]. Ez a módszer Drosophila késői ivarvonal-fejlődés során bizonyára jól használható funkcióvesztéses vizsgálatokra, de korai embriókban ezek a 
transzgének feltehetőleg nem fejeződnek ki, mivel az ivarvonalban a génexpresszió sokáig represszált. Jelenleg nincs pontos információnk arról, hogy a Drosophila ivarvonalban az GAL4-UASp rendszerrel aktivált géncsendesítés a fejlődés mely stádiumaiban müködik hatékonyan.

A

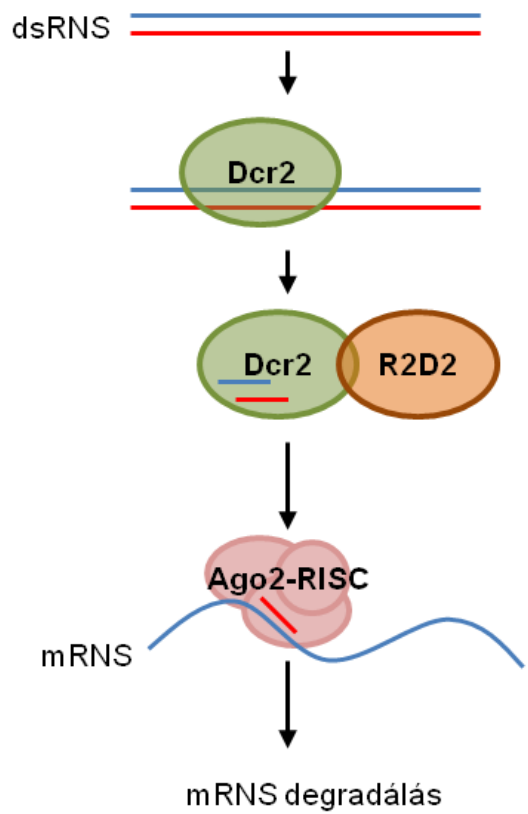

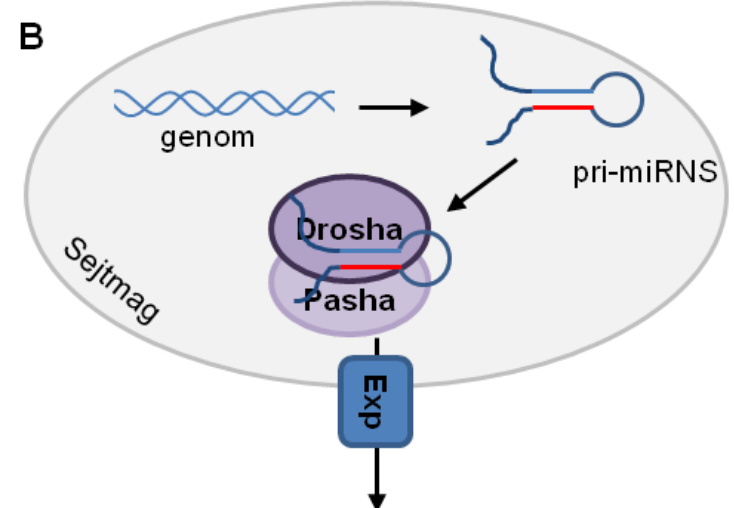

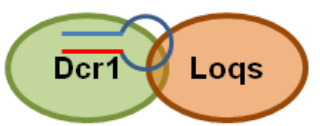

pre-miRNS

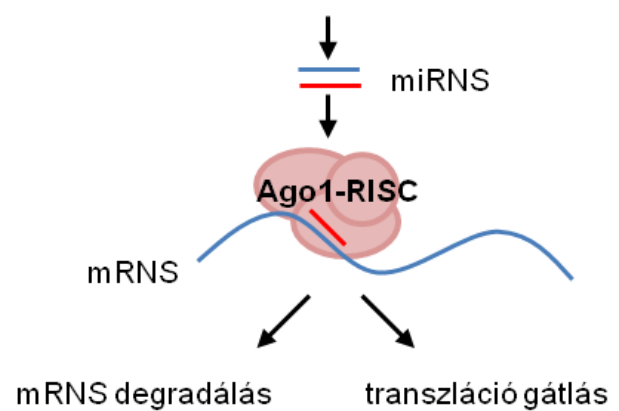

8. ábra: Géncsendesítés siRNS és miRNS útvonalon keresztül. A: Az siRNS útvonal Dicer2 (Dcr2) enzime az akár több száz bp hosszúságú dupla szálú RNS molekulákat 21 nukleotidos siRNS-ekké darabolja. A Dcr2 és R2D2 fehérjék segítségével a kis RNS-ek betöltődnek az Argonaute-2-RISC effektor komplexbe, amely a cél-mRNS felismerést és degradációját végzi. B: A miRNS-útvonalon keresztül ható géncsendesítés esetén a genomról íródik át a mesterséges miRNS-transzgén (elsődleges, vagy pimary-miRNS, pri-miRNS), amelynek érésében a Drosha-Pasha fehérjekomplex vesz részt. A jellegzetes hajtủ szerkezetủ pre-miRNS exportin fehérje segítségével jut ki a sejtmagból, a Dicer1 (Dcr1) és Loquacious (Lqs) fehérjékböl álló komplexhez kötődik, ahol további érésen megy keresztül. Az érett miRNS az Ago1-RISC fehérjekomplexhez kapcsolódik, amely a cél-mRNS felismerésében vesz részt. A miRNS útvonalon ható géncsendesítés nem csak mRNS degradáció, hanem transzláció gátlás által is kifejtheti hatását [63].

A Drosophila embrionális ivarsejtjeiben kifejeződő gének RNSi-val történő vizsgálatára megoldást jelenthet a dsRNS-ek injektálással történő bejuttatása. Ez a 
módszer hatékonyan eliminálja az anyai hatással átadott mRNS-eket [64], valamint az embrionális fejlődés későbbi szakaszaiban kifejeződő géneket is hatékonyan csendesítheti [65].

Az embrionális korban kifejeződő gének vizsgálata esetén a géncsendesítés számos előnnyel bír a klasszikus mutáns allélok vizsgálatával szemben. A legtöbb vizsgálni kívánt génnek nem ismert mutáns allélja, valamint az elérhető allélok többsége is kevéssé jellemzett. A klasszikus mutánsokkal való munka esetén nehézséget jelenthet, hogy az elérhető mutánsok eltérő genetikai háttérrel rendelkeznek, ami megnehezíti a fenotípusok összehasonlítását. Ezek a problémák géncsendesítés esetén nem állnak fenn, hiszen génspecifikus dsRNS-ekkel mindegyik Drosophila gén csendesítése megvalósítható, mégpedig oly módon, hogy a fenotípusokat azonos genotípusú állatokon vizsgáljuk. Korai Drosophila embriókban kifejeződő gének vizsgálatakor nem elhanyagolható kérdés, hogy egy adott géntermék anyai hatású módon, vagy zigotikusan fejeződik-e ki. Még a transzkriptóma analízisek korában sem könnyü a gének jelentős részéröl eldönteni ezt az igen lényeges kérdést. A mutáns allélok vizsgálata esetében a géntermék eredete határozza meg, hogy a mutációt anyai, vagy zigotikus fenotípusok vizsgálatára alkalmas kísérleti elrendezésben kell-e vizsgálni. Géncsendesítésnél ezzel a problémával nem kell szembenézni, hiszen a korai embrióba bejuttatott dsRNS az anyai és zigotikus eredetü mRNS-eket egyaránt csendesíti. A géncsendesítés további előnye a mutánsok vizsgálatával szemben, hogy a vizsgált gén pleiotróp hatása kiküszöbölhető, mert a géncsendesítés az egyedfejlődés során a kívánt időben, és akár szövetspecifikusan is aktiválható.

Tapasztalatok szerint a dsRNS injektálásával nem lehet teljes mértékü géncsendesítést elérni, valamint az injektálás embriónként más-más RNSi hatékonyságot eredményez. Ez azonban azt is lehetővé teszi, hogy eltérő 
expresszivitású fenotípusokból álló fenotípus sorozatot állítsunk elő. A géncsendesítés további fontos sajátsága, hogy a már transzlálódott fehérjékre a géncsendesítés nem hat, ezért bizonyos esetekben (különösen stabil fehérjetermékek esetén) a funcióvesztéses hatás nem valósítható meg.

Összevetve tehát a rendelékezésre álló lehetőségek előnyei és hátrányait, a Drosophila embrió ivarvonalában kifejeződő gének reverz genetikai vizsgálatára a géncsendesítés tűnik a legmegfelelőbb módszernek. A génspecifikus dsRNS-oldat korai embriókba való injektálása lehetővé teszi a vizsgált gének hatásának tanulmányozását az embrionális ivarvonalban. 


\section{Célkitüzések}

Kutatócsoportunk érdeklődésének központjában a Drosophila ivarsejtfejlődésért felelős gének azonosítása és vizsgálata áll. A korábbi munkáink során elsősorban a forward genetika eszköztárát felhasználva klasszikus transzpozon mutagenezissel, illetve genetikai interakción alapuló mutáns izolálási kísérletekkel azonosítottunk ivarsejt-fejlődésben szerepet játszó géneket [48,49].-A biológiai adatbázisok intenzív fejlődése lehetővé tette, hogy összeállítsuk a Drosophila embrionális ivarvonalban specifikusan kifejeződő gének listáját, és ez alapján reverz genetikai kísérletsorozatot tervezzünk. PhD munkám témája az ivarsejt-specifikus kifejeződést mutató gének funkcionális genetikai jellemzése RNSi alapú reverz genetikai kísérletsorozattal. A bemutatott munkában választ kerestünk arra a kérdésre, hogy az embrionális ivarsejt transzkriptóma funkcionálisan redundáns-e, vagyis, hogy az ivarsejtekben kifejeződő, hasonló szerkezetű fehérjék képesek-e helyettesíteni egymás funkcióját. Munkánk további részében az RNS interferencián alapuló kísérletsorozat jelölt génjei evolúciós viszonyainak feltárását, és a gének funkciójának felderítését tüztük ki célul. Továbbá célunk volt az RNSi kísérletsorozat néhány ígéretes jelölt génjének részletesebb genetikai vizsgálata. Dolgozatomban az elvégzett kísérleteket, azok eredményeit és az eredményekböl levonható következtetéseket kívánom bemutatni. 


\section{Anyagok és módszerek}

\subsection{Genomi DNS izolálása Drosophila melanogasterből}

$30 \mathrm{db}$ felnőtt állatot fagyasztottunk, majd $400 \mu$ l homogenizáló pufferben (100mM Tris-HCl, pH 7,5; 100mM EDTA; 100mM NaCl; $0.5 \%$ SDS) homogenizáltuk. A homogenizátumot 30 percig $65^{\circ} \mathrm{C}$-on inkubáltuk, majd $800 \mu \mathrm{l}$ feltáró puffert $(1: 2,55 \mathrm{M} \mathrm{KO}$-acetát: $6 \mathrm{M} \mathrm{LiCl})$ adtunk a mintához, egy órán át tartó szobahőn való inkubálás után centrifugáltuk (13000g, 15 perc, szobahő). A felülúszóból $1 \mathrm{ml-t}$ új mikrocentrifuga-csőbe helyeztünk, $600 \mu 1$ izopropanolt adtunk hozzá, majd centrifugáltuk (13000g, 15 perc, szobahő). A kicsapódó DNS-t 70\%-os etanollal mostuk, vákuumelszívóban szárítottuk, és steril TE pufferben (10mM Tris; 1mM EDTA; pH 8) oldottuk. A DNS oldatot 10ng/ $\mu$ l végtérfogatú RNáz A-val kezeltük, majd 2 térfogatnyi fenolt adtunk hozzá, és centrifugáltuk (16000g, 1 perc, szobahő). A felülúszó fázishoz 2 térfogatnyi fenol:kloroform:izoamil-alkohol 25:24:1 elegyet mértünk, majd centrifugáltuk (16000g, 1 perc, szobahő). A felső fázishoz 2 térfogatnyi kloroform:izoamil-alkohol 24:1 elegyet mértünk, ismét centrifugáltuk (16000g, 1 perc, szobahő). A felülúszó fázisból a DNS-t 0,1 térfogatnyi 3M Naacetáttal és 2 térfogatnyi $96 \%$-os, $-20^{\circ} \mathrm{C}$-os etanol hozzáadásával csaptuk ki $-80^{\circ} \mathrm{C}$-on egy órán át. Az elegyet centrifugáltuk (16000g, 10 perc, szobahő), a kicsapódott DNS-t 70\%, majd 90\%-os etanollal mostuk, vákuumszárítóban szárítottuk, steril TE pufferben oldottuk. 


\subsection{Géncsendesítő kettős szálú RNS-ek szintézise}

A csendesítésre kiválasztott génekre 166-614 bp (átlagosan: 300bp) hosszúságú homológ géncsendesítő dsRNS-eket terveztünk. A gének szekvenciáit a FlyBase adatbázisból (http://flybase.org) töltöttük le. Az esetleges off-target hatást a dsCheck online szoftverrel ellenőriztük [66]. A kiválasztott szekvenciákra primer3 program segítségével [67] olyan primereket terveztünk, melyek 5'-végükön egy 5'-

GGATC-3' extra szekvencia után T7 polimeráz promótert (5'TAATACGACTCACTATAGGG-3') tartalmaztak (Függelék 1. táblázat). A primereket az Eurofins MWG Synthesis GmbH-val szintetizáltattuk, és HPSF (High purity salt free purification) módszerrel tisztítattuk. A primerek segítségével polimeráz láncreakcióval (PCR) genomi DNS templátról génspecifikus DNS szakaszokat amplifikáltunk. A PCR reakciót $100 \mu l$ térfogatban végeztük $\left(+\left(\mathrm{NH}_{4}\right)_{2} \mathrm{SO}_{4}\right.$ puffer, 2,5mM $\mathrm{MgCl}_{2}, 1 \mathrm{mM}$ dNTP mix, 28ng/ $\mu 1 \mathrm{DNS}, 0,01 \mathrm{U} / \mu 1$ Taq DNS polimeráz) a következö programmal: $96^{\circ} \mathrm{C} 2$ perc, $2 \times\left(94^{\circ} \mathrm{C} 45 \mathrm{mp}, 58^{\circ} \mathrm{C} 1\right.$ perc, $\left.72^{\circ} \mathrm{C} 45 \mathrm{mp}\right)$, $40 \mathrm{x}\left(94^{\circ} \mathrm{C} 45 \mathrm{mp}, 66^{\circ} \mathrm{C} 1\right.$ perc, $\left.72^{\circ} \mathrm{C} 45 \mathrm{mp}\right), 72^{\circ} \mathrm{C} 2$ perc. A PCR terméket a QIAGEN QIAquick PCR purification Kit-tjével tisztítottuk, a fragmentek méretét 1\%-os agaróz gélen ellenőriztük, koncentrációjukat Nanodrop müszerrel mértük. A PCR termékeket templátként használva in vitro transzkripcióval készítettünk kettős szálú RNS-t. A reakciót a Promega T7 RiboMAX ${ }^{\mathrm{TM}}$ Express Large Scale RNA Production System-jével végeztük 1 órán át, $37^{\circ} \mathrm{C}$-on, $25 \mu \mathrm{l}$ végtérfogatban, templátként $1 \mu \mathrm{g}$ PCR terméket használva. A mintákat ezután RQ1 RNáz mentes DNázzal kezeltük $\left(1 \mathrm{U} / \operatorname{minta}, 37^{\circ} \mathrm{C}, 30\right.$ perc). Az in vitro transzkripció terméket kicsaptuk: 0,1 térfogat 3M Na-acetátot és 1 térfogat isopropanolt adtunk hozzá, majd 10 percig inkubáltuk jégen, centrifugáltuk $\left(16000 \mathrm{~g}, 15\right.$ perc, $\left.4^{\circ} \mathrm{C}\right), 70 \%$-os etanollal mostuk, ismét centrifugáltuk $\left(16000 \mathrm{~g}, 5\right.$ perc, $\left.4^{\circ} \mathrm{C}\right)$, majd a csapadékot vákuumban 
szárítottuk, végül $30 \mu 1$ RNáz mentes vízben vettük fel. Az RNS-ek méretét 1,5\%-os agaróz gélen ellenőriztük, koncentrációjukat Nanodrop müszerrel mértük. Az $1 \mu \mathrm{g} / \mu \mathrm{l}$ koncentrációjúra hígított dsRNS oldatokat $-20^{\circ} \mathrm{C}$-on tároltuk felhasználásig.

\subsection{Géncsendesítés Drosophila embriókban}

A 0-1 órás $w^{1118}$; nos-Moe.EGFP.nos3'UTR (nos-Moe-EGFP) genotípusú Drosophila embriókat 50\%-os hipóval (NaOCl) dekorionizáltuk, hasoldalukkal ragasztóval (heptánban oldott kétoldalú ragasztószalag, 3M) bevont tárgylemezre rögzítettük. Injektáló pufferben $\left(5 \mathrm{mM} \mathrm{KCl}, 0,1 \mathrm{mM} \mathrm{Na}_{3} \mathrm{PO}_{4}, \mathrm{pH}: 6,8\right)$ oldott $1 \mu \mathrm{g} / \mu \mathrm{l}$ töménységű kettős szálú RNS-oldatot üveg mikrokapillárissal oldal irányból injektáltuk az embriókba $18^{\circ} \mathrm{C}$-on. A génspecifikus dsRNS-eket Michael Boutros laboratóriumától kaptuk (Heidelberg2 dsRNS gyüjtemény) [68]. Egy-egy dsRNS oldattal 60 embriót injektáltunk. Az injektált embriókat Voltalef PVTFE 10S olajjal fedtük le. A nos-Moe-EGFP fehérjét kifejező ivarsejteket in vivo video-mikroszkópia segítségével követtük nyomon. A felvételeket az Image J szoftver segítségével jelenítettük meg. Fenotípus kategóriákat azonosítottunk, a megfigyelt rendellenességeket kategóriákba soroltuk, és meghatároztuk azok előfordulási gyakoriságát. A fenotípus kategóriákat hierarchikus klaszterezéssel elemeztük. A géncsendesítések fenotípus-eloszlásának hasonlóságát Pearson korreláció alapján, „average linking clustering” módszerrel határoztuk meg. Az egyes géneket fenotípuseloszlásuk és -gyakoriságuk szerint hőtérképen ábrázoltuk a Multi Experiment Viewer szoftver segítségével [69]. Az injektált embriókat a video-mikroszkópiás vizsgálat után standard Drosophila táptalajra helyeztük, az ezekből kifejlődő felnőtt állatokat felboncoltuk, és megállapítottuk az ivarsejthiányos fenotípusok penetranciáját. 


\subsection{Mutáns allélok vizsgálata érzékenyített genetikai háttéren}

A vizsgálandó gének alléljait (Függelék: 2. táblázat) a következő Drosophila törzsgyüjteményekből szereztük be: Bloomington Drosophila Stock Center at Indiana University (http://flystocks.bio.indiana.edu); The Exelixis Collection at the Harvard Medical School (https://drosophila.med.harvard.edu); DGRC, Kyoto Stock Center (http://www.dgrc.kit.ac.jp) Szeged Drosophila Stock Center (megszünt). A mutáns allélok ivarsejthiányt okozó fenotípusát érzékenyített genetikai háttéren vizsgáltuk. Kontrollként $w^{1118}$ genotípusú állatokat használunk. A szülői nemzedékben (P) stau ${ }^{\Delta 3}$, $o s k^{54}, T m I I^{e 14}$ funkcióvesztéses allélokat hordozó $\left(w^{1118} ; \operatorname{stau}^{D 3} \mathrm{cn}^{2} / S m 6 b c n^{2} ; s t^{1}\right.$ $o s k^{54} \operatorname{TmII}^{\text {e14}} / \mathrm{TM} 3 \mathrm{Sb}^{1} \mathrm{Ser}^{1}$ ) szüz nőstényeket kereszteztünk a vizsgálandó, a kívánt mutáns allélt hordozó hímmel. Az utódnemzedékből $\left(\mathrm{F}_{1}\right)$ azokat a transz-heterozigóta szüz nőstényeket válogattuk ki, melyek a $\operatorname{stau}^{43}$, osk ${ }^{54}, T_{m I I}{ }^{14}$ mutációk mellett a vizsgálni kívánt allélt is hordozták. Ezeket az állatokat a domináns markereket hordozó balanszer-kromoszómák hiánya alapján azonosítottuk. A kiválasztott nőstényeket $w^{1118}$ hímekkel kereszteztük. A második utódnemzedék $\left(\mathrm{F}_{2}\right)$ nőstényeit felboncoltuk, ivarsejthiányos fenotípust keresve. Megállapítottuk az ivarsejthiányt mutató fenotípus petefészkek (nem a petefészek párok) előfordulási gyakoriságát (penetranciáját). 


\subsection{Indirekt immunofluoreszcens jelölés Drosophila embriókon és szerveken}

Indirekt immunofluoreszcens festést Drosophila embriókon, lárvák és kifejlett állatok ivarszervein végeztünk. Ezen eljárások kezdeti lépései eltérnek, ezért ezeket külön mutatom be:

1. Az embriókat 50\% hipóban dekorionizáltuk, majd 4\%-os formaldehidet tartalmazó PBS (137mM NaCl, 2,68mM KCl, 10,14mM Na $2 \mathrm{HPO}_{4}, 1,76 \mathrm{mM}$ $\mathrm{KH}_{2} \mathrm{PO}_{4}$ ), heptán 1:1 elegyében fixáltuk 20 percig. A vizes fázis eltávolítása után az embriókat tartalmazó heptánhoz még egyszer ennyi $-20^{\circ} \mathrm{C}$-os metanolt adtunk, erős rázással a vitellin membránt eltávolítottuk. Az embriókat ezután metanolból fokozatosan átmostuk PBT-be (PBS, 0,1\% Triton-X), majd csak PBT-ben mostuk.

2. A lárvális ivarszerveket Drosophila Ringerben boncoltuk, majd 4\%-os formaldehidet tartalmazó PBS-ben 20 percig fixáltuk, majd háromszor metanollal, háromszor PBT-vel mostuk.

3. A kifejlett állatok ivarszerveit Drosophila Ringer oldatban boncoltuk, majd 4\%-os formaldehidet tartalmazó PBS-ben 20 percig fixáltuk, és PBT-vel mostuk.

A mintákat 2\% BSA-t és 5\% FCS-t tartalmazó PBT oldatban (PBT-N) 1 órán át blokkoltuk, majd $4{ }^{\circ} \mathrm{C}$-on éjszakán át elsődleges ellenanyaggal inkubáltuk. A nem kötődött elsődleges ellenanyagot PBT-ben történő háromszori mosással távolítottuk el. A megfelelő, fluoreszcensen jelölt másodlagos ellenanyagokkal (Invitrogene, 600szoros hígítás PBT-N-ben) és egyéb festékekkel egy órán át inkubáluk a mintákat. Az szerveket ismét PBT-ben mostuk háromszor, végül Fluoromount-G mounting mediumban fedtük le. A felhasznált elsődleges, másodlagos ellenanyagokat és festékeket az 1. táblázat mutatja. 


\begin{tabular}{|c|c|c|}
\hline Elsődleges ellenanyag & Másodlagos ellenanyag 600x & Egyéb festékek \\
\hline $\begin{array}{l}\mathrm{dC}-13 \text { (kecske) PK 50x } \\
\text { Vasa, ivarvonal sejtek jelölése }\end{array}$ & $\begin{array}{l}\text { anti-kecske Alexa-488 (szamár) } \\
\text { anti-kecske Alexa546 (szamár) }\end{array}$ & \multirow{12}{*}{$\begin{array}{l}\text { DAPI 500x } \\
\text { DNS jelölése } \\
\text { Rhodamine- } \\
\text { phalloidine 20x } \\
\text { Aktin-fehérje } \\
\text { jelölése }\end{array}$} \\
\hline $\begin{array}{l}\text { anti-vasa (patkány) PK 300-500x } \\
\text { varvonal sejtek jelölése }\end{array}$ & anti-patkány Alexa488 (csirke) & \\
\hline $\begin{array}{l}\text { anti-GFP (nyúl) MK 500x } \\
\text { GFP transzgént kifejező sejtek } \\
\text { jelölése }\end{array}$ & $\begin{array}{l}\text { anti-nyúl Alexa546 (szamár) } \\
\text { anti-nyúl Alexa647 (szamár) }\end{array}$ & \\
\hline $\begin{array}{l}\text { 1B1 (egér) PK 30x } \\
\text { HTS-fehérje, spektroszómák, } \\
\text { fuzómák, follikulári sejtek } \\
\text { sejthártyjának jelölése }\end{array}$ & $\begin{array}{l}\text { anti-egér Alexa647 (nyúl) } \\
\text { anti-egér Alexa647 (kecske) } \\
\text { anti-egér Alexa546 (kecske) }\end{array}$ & \\
\hline $\begin{array}{l}\text { anti-Tj (tengerimalac) PK 30000x } \\
\text { Lárvális ivarszervek szomatikus } \\
\text { sejtjeinek jelölése }\end{array}$ & $\begin{array}{l}\text { anti-tengerimalac Alexa546 } \\
\text { (kecske) }\end{array}$ & \\
\hline $\begin{array}{l}\text { E7 (egér) PK 30x } \\
\beta \text {-tubulin, spermium farok jelölése }\end{array}$ & $\begin{array}{l}\text { anti-egér Alexa647 (nyúl) } \\
\text { anti-egér Alexa647 (kecske) } \\
\text { anti-egér Alexa546 (kecske) }\end{array}$ & \\
\hline anti-Feo (nyúl) PK 100x & anti-nyúl Alexa647 (szamár) & \\
\hline $\begin{array}{l}\text { anti-y-tubulin (egér) MK 50x } \\
\text { Centroszómák jelölése }\end{array}$ & anti-egér Alexa647 (kecske) & \\
\hline $\begin{array}{l}\text { anti-smt3 PK (nyúl) } \\
\text { SUMO fehérje jelölése }\end{array}$ & $\begin{array}{l}\text { anti-nyúl Alexa488 (csirke) } \\
\text { anti-nyúl Alexa647 (szamár) }\end{array}$ & \\
\hline $\begin{array}{l}\text { F2F4 (egér) MK 4x } \\
\text { Cyclin B fehérje jelölése }\end{array}$ & anti-egér Alexa647 (kecske) & \\
\hline $\begin{array}{l}\text { anti-Mei-P26 (nyúl) PK 200x } \\
\text { Mei-P26 fehérje jelölése }\end{array}$ & anti-nyúl Alexa546 (szamár) & \\
\hline $\begin{array}{l}\text { anti-pSmad/41D10 (nyúl) MK 100x } \\
\text { Foszforilált Smad, aktív BMP } \\
\text { szignáltarnaszdukciós útvonal } \\
\text { jelölése }\end{array}$ & anti-nyúl Alexa546 (szamár) & \\
\hline
\end{tabular}

1. táblázat. A Drosophila embriókon végzett indirekt immunofluoreszcens festéshez használt ellenanyagok és egyéb festékek és alkalmazott hígításuk. PK: poliklonális ellenanyag, MK: monoklonális ellenanyag.

\subsection{Géncsendesítés Drosophila ivarvonalban transzgenikus shRNS-ekkel}

Az ivarvonalban kifejeződő, P\{GAL4::VP16-nos.UTR\} (nos-GAL4-VP16) harmadik kromoszómás transzgenikus GAL4-forrást (aktivátort) hordozó, homozigóta szűz nőstényeket kereszteztük UAS-enhanszerrel ellátott génspecifikus shRNS 
transzgéneket hordozó hímekhez $29^{\circ} \mathrm{C}$-on (Függelék 2. táblázat). A kettős transzgenikus utódokat kifejlett korban felboncoltuk és meghatároztuk az csökevényes ivarszervek előfordulási gyakoriságát. Meggyőző ivarsejthiányos fenotípus esetén a csökevényes gonádok ivarsejt-tartalmát ivarsejtvonal-specifikus antitestek felhasználásával indirekt immunofluoreszcencia segítségével vizsgáltuk. Amennyiben a $F_{1}$ generáció fertilisnek bizonyult, a GAL4-forrást és a shRNS transzgént egyaránt hordozó szüz nőstényeket vad típusú hímekkel kereszteztük, a csökevényes felnőtt ivarszervek előfordulását az $F_{2}$ generációban is boncolással határoztuk meg. A transzgenikus GAL4-forrást és a shRNS-eket hordozó vonalakat a bloomingtoni Drosophila törzsgyüjteményböl szereztük be.

\subsection{Mikroszkópia}

A felhasznált Drosophila törzsek vizsgálatát, a lárvális és kifejlett állatok szerveinek boncolását sztereomikroszkóp alatt végeztük el. A kifejlett állatok petefészkeit Leica MZ FLIII fluoreszcens sztereomikroszkóp segítségével fényképeztük. A géncsendesítéses kísérletsorozatban a dsRNS-sel injektált 2-14. stádiumú embriók GFP-t kifejező ivarsejtjeit in vivo video-mikroszkópiával követtük nyomon az Olympus CellR Live Imaging Work Station rendszerén $25^{\circ} \mathrm{C}$-on $(5 \mathrm{x}$ objektív, 1375x1038 pixel felbontás, 3-9 embrió/felvétel, 1 felvétel/10 perc, $180 \mathrm{~ms}$ expozíciós idő). Az injektált embriókról készült felvételsorozatokat ImageJ szoftver segítségével jelenítettük meg, és értékeltük ki. A konfokális mikroszkópiás felvételek készítésére az Olympus FW1000 és Leica TCS SP5 konfokális mikroszkópokat használtuk. A felvételek megjelenítését, szerkesztését, kiértékelését az ImageJ, a Leica LASAF és a GIMP szoftverek segítségével végeztük el. 


\section{8 shRNS-transzgének tervezése, transzformálása}

A célgén mRNS-ére specifikus 21bp-os szekvenciát a DSIR (http://biodev.cea.fr/DSIR/) online szoftver segítségével választottuk ki. A lehetséges off-target szekvenciákat a FlyBase adatbázis BLAST algoritmusával szürtük ki (http://flybase.org/blast/). A kiválasztott, célgén-specifikus szekvenciákat a human miR1 mikro-RNS szerkezetébe illesztettük a következőképpen:

Felső szál: 5'-ctagcagtN(21)tagttatattcaagcataN*(21)gcg-3'

Alsó szál: 5'-aattcgcN(21)tatgcttgaatataactaN*(21)actg-3', ahol a kisbetüs szekvenciák a humán miR1 szerkezeti elemei; N(21) a célgén-specifikus, 21n-os szensz-szekvencia; $\mathbf{N * ( 2 1 )}$ pedig a célgén-specifikus, 21n-os antiszensz szekvencia. Az így tervezett 71n-os oligonukleotidokat megszintetizáltattuk, és HPSF módszerrel tisztíttattuk. Az oligonukleotidokat 2-2 $\mu \mathrm{M}$-os végkoncentrációban, annealing pufferben (10mM Tris-HCl, pH 7,5; 0,1M NaCl; $1 \mathrm{mM}$ EDTA) $96^{\circ} \mathrm{C}$-ról $25^{\circ} \mathrm{C}$-ra, 3 óra alatt egyenletesen visszahütve olvasztottuk össze. Az így kapott NheI és EcoRI túlnyúló végekkel rendelkező kettősszálú oligonukleotidot NheI és EcoRI restrikciós endonukleázokkal linearizált VALIUM22 vektorba ligáltuk $18^{\circ} \mathrm{C}$-on 1 órán át $20 \mu 1$ térfogatban $(0,6 \mu \mathrm{M}$ összeolvasztott oligonukleotid, ligáz puffer $(40 \mathrm{mM}$ Tris- $\mathrm{HCl}$, 10mM MgCl2, 10mM DTT, 0,5mM ATP, pH 7,8), 5U T4 DNS-ligáz, 40ng linearizált VALIUM20 plazmid) [70]. A ligált plazmidot E.coli TOP10 kompetens sejtekbe transzformáltuk. A transzformált sejteket szilárd LB táptalajra szélesztettük, a felnövő telepekből plazmid DNS-t tisztítottunk QIAprep® Spin Miniprep segítségével. A beépült oligonukleotidok azonosítása érdekében a tisztított plazmidon ellenőrző PCR$\mathrm{t}\left(96^{\circ} \mathrm{C} 2\right.$ perc, $35 \mathrm{x}\left(94^{\circ} \mathrm{C} 45 \mathrm{mp}, 58^{\circ} \mathrm{C} 45 \mathrm{mp}, 72^{\circ} \mathrm{C} 45 \mathrm{mp}\right) 72^{\circ} \mathrm{C} 2$ perc) végeztünk. a következő primerek használatával: 
V22F: 5'-ACCAGCAACCAAGTAAATCAAC-3'

V22R: 5'-TAATCGTGTGTGATGCCTACC-3'

Az V22F primer segítségével szekvenáltattuk a plazmid DNS-t. A megfelelő szekvenciájú plazmidokat injektáló pufferben 300ng/ $\mu$ l-es koncentrációban, $y^{l} v^{l}$ $P\left\{\right.$ nos-ФC31\}; P\{Carry-P\}attP40 és $y^{1} v^{1} P\{$ nos- $Ф C 31\} ; P\{$ Carry-P\}att2 genotípusú Drosophila embriókba injektáltuk, és a transzgént hordozó egyedi hímekből transzgenikus vonalakat alapítottunk.

\subsection{A jelölt gének evolúciós viszonyainak feltárása}

Az RNS interferencia kísérletsorozat 48 jelölt génjének evolúciós viszonyait a FlyBase (http://flybase.org) és az Ensemble adatbázis (http://www.ensembl.org) alapján térképeztük fel. Ortológ géneket a jól jellemzett élesztő (Saccharomyces cerevisiae), fonalféreg (Caenorhabditis elegans), karmosbéka (Xenopus tropicalis) egér (Mus musculus) és emberi genomokban kerestünk, ezen kívül az evolúciós viszonyokat vizsgáltuk a gyümölcslegyek családjában (Drosophilidae); rovarok osztályában (Insecta) és az ízeltlábúak törzsében (Arthropoda). Ezen gének ivarsejtfejlődésben betöltött szerepéről a MEDLINE adatbázisból a PubMed kereső segítségével (http://www.ncbi.nlm.nih.gov/pubmed) gyüjtöttünk információt. 


\section{Eredmények}

\subsection{Az embrionális ivarvonal-specifikus kifejeződést mutató gének funkcionális jellemzése}

Az mRNS lokalizációs adatbázisok és egy embrionális gonádokból készült EST-gyüjtemény alapján több mint ötszáz olyan gént azonosítottunk, melyek RNSterméke a korai Drosophila embriók ivarplazmájában, vagy az embrionális fejlödés későbbi szakaszában, az embrionális ivarsejtekben, vagy gonádokban fejeződik ki, vagy ott legalábbis feldúsulást mutat. Géncsendesítő kísérletsorozatunkkal arra a kérdésre kívántunk választ kapni, hogy az ilyen kifejeződést mutató gének csendesítésének van-e közvetlenül hatása az embrionális ivarsejtek, vagy az ivarszervek kialakulására, fejlődésére. A technika lehetővé teszi a géncsendesített embriók felnevelését felnőtt korig, ezért alkalmas arra is, hogy géncsendesített állatok ivarszerveit ebben a fejlődési állapotban is vizsgáljuk.

\subsubsection{A vizsgálandó gének kiválasztása}

Az embrionális ivarsejtekben specifikusan kifejeződő gének listáját három adatforrás segítségével határoztuk meg. A Berkeley Drosophila Genome Project (BDGP) Drosophila embriók génexpressziós mintázatának adatbázisa 3418 gén embrionális RNS-lokalizációját mutatja be (http://www.fruitfly.org/) [51]. Az adatbázis alapján összesen 334 olyan gént választottunk ki a géncsendesítésen alapuló kísérletsorozathoz, melyek mRNS-e csak az embrionális ivarsejtekben, vagy 
ivarszervekben fejeződik ki, vagy ott a szomatikus szövetekhez képest magas szinten expresszált.

A Fly-FISH mRNS lokalizációs mintázatok adatbázisa az embrionális fejlődés 9. stádiumáig követi nyomon 3370 gén RNS-termékének embrionális lokalizációját fluoreszcens in situ hibridizációs technika segítségével (http://flyfish.ccbr.utoronto.ca) [52]. A Fly-FISH adatbázis szerint 211 gén mutat ivarsejtspecifikus kifejeződést mRNS szinten az embrionális fejlődés 9. stádiumáig.

Shigenobu és munkatársai embrionális gonádból mintegy 3000 gén mRNS-ét reprezentáló cDNS könyvtárat készítettek, és jellemeztek [54]. RNS in situ hibridizációs technika alkalmazásával a cDNS könyvtárból 38, a gonád csíravonalában kifejeződő gént írtak le, melyekkel kiegészítettük jelölt listánkat. A három különböző forrásból származó génlista között átfedés tapasztalható, melynek mértékét a 9. ábra mutatja be. Megállapítható, hogy forrásaink alapján nem tudunk teljes képet adni az embrionális ivarplazmában, ivarsejtekben, vagy gonádokban kifejeződő génekről, hiszen a két adatbázis összesen 4644 gént vizsgál, ami a Drosophila melanogaster genomprogram 5.23 frissítése szerint a genomban kódolt összes gének 31,2\%-át jelenti, Shigenobu pedig csak 3000 gén kifejeződését vizsgálta.

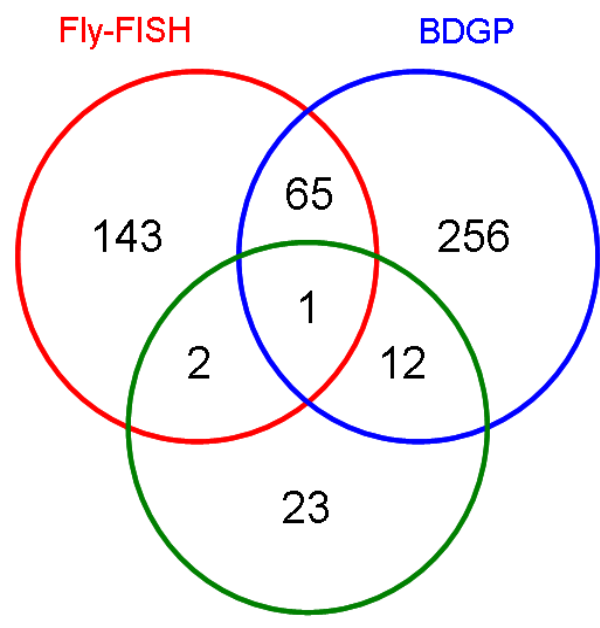

EST
9. ábra: Géncsendesítéshez kijelölt gének kiválasztása különböző források alapján. Két RNS-lokalizációs adatbázis és egy gonád cDNS gyüjtemény alapján 502 ivarplazmában, embrionális ivarsejtekben, vagy gonádokban kifejeződő gént választottunk ki géncsendesítő kísérletsorozatunkhoz. 


\subsubsection{A géncsendesítő kísérletsorozat menete}

A géncsendesítő kísérletsorozat során összesen 502 gén funkcionális genetikai vizsgálatát hajtottuk végre. A génspecifikus dsRNS-oldatot üveg mikrokapilláris segítségével injektáltuk olyan 1-2. stádiumos nos-Moe.EGFP.nos3'UTR genotípusú Drosophila embriókba, amelyek ivarsejtjei a nanos gén promóterével és 3' nem transzlálódó régiójával ellátott GFP fúziós fehérjét fejeznek ki, lehetővé téve ezáltal az ivarsejtek sorsának in vivo video-mikroszkópiás nyomon követését embrionális korban. E korai fejlődési állapotban, a szincíciális blasztoderma stádiumban lévő embriókban a sejthatárok még nem alakulnak ki, ezért az injektált dsRNS-ek eloszlása akadálytalan. Az embriókat $1 \mu \mathrm{g} / \mu \mathrm{l}$ koncentrációjú dsRNS-oldattal injektáltuk. Irodalmi adatok és munkatársaim tapasztalata alapján (Jankovics Ferenc, Köllőd Borbála, szóbeli közlés) e koncentráció mellett mérhető ki a legerősebb, specifikus fenotípus a lehető legalacsonyabb aspecifikus hatás mellett [71].

Az injektált embriókat 0,5-4 órás koruktól (2-9. stádiumtól) kezdődően 13 órán át filmeztük. A felvételek kiértékelése során szabad szemmel állapítottuk meg az egyes embriók ivarsejtjeinek hozzávetőleges számát, illetve azt, hogy elhelyezkedésük megfelel-e vad típusú embriók fejlődési állapotának.

\subsubsection{A géncsendesítő kísérletsorozat kontrolljai}

A dsRNS-ek injektálásával történő géncsendesítés több lépésből álló kísérleti eljárás, mely meglehetősen durva fizikai behatást jelent a vizsgált embriókra. Az injektálás nélküli kezelés (dekorionizálás, üveglemezre ragasztás, halokarbon olajjal fedés, mikroszkópos vizsgálat) hatását azonos genotípusú injektálatlan kontroll embriókon mértük ki. Az injektálás az embriókra gyakorolt háttér hatását pufferrel 
injektált kontroll embriókon vizsgáltuk. A dsRNS injektálásának esetleges aspecifikus hatásait hét, a Drosophila embrionális fejlődése során ki nem fejeződő gén csendesítésével zártuk ki. A kísérletsorozat pozitív kontrolljaként a nanos gént csendesítettük, ugyanis irodalmi adatok alapján elvárható, hogy ez a csendesítés mutáns ivarsejt és gonád fenotípusokat eredményezzen. A kísérletsorozatban használt kontrollok az embriók életképességére és az ivarsejt-fenotípusokra gyakorolt hatását a 2. táblázat mutatja be.

\begin{tabular}{|c|c|c|c|c|c|c|}
\hline Kontroll & Kontrollált tényező & $\begin{array}{l}\text { Eset- } \\
\text { szám }\end{array}$ & $\begin{array}{c}\text { Túlélő } \\
\text { embrió } \\
(\%)\end{array}$ & $\begin{array}{c}\text { Embrionális } \\
\text { ivarsejt } \\
\text { fenotípus } \\
(\%)\end{array}$ & $\begin{array}{c}\text { Esetszám } \\
\text { (kifejlett } \\
\text { állat) }\end{array}$ & $\begin{array}{c}\text { Ivarsejt } \\
\text { fenotípus } \\
\text { kifejlett } \\
\text { állatban (\%) }\end{array}$ \\
\hline Injektálatlan & embriók kezelése & 60 & 75,0 & 2,2 & 32 & 0 \\
\hline $\begin{array}{l}\text { Pufferrel } \\
\text { injektált }\end{array}$ & $\begin{array}{l}\text { embriók kezelése és } \\
\text { injektálás }\end{array}$ & 541 & 51,3 & 15,1 & 69 & 3,6 \\
\hline $\begin{array}{l}\text { Indifferens } \\
\text { gének átlaga } \\
\text { (szórás) }\end{array}$ & $\begin{array}{l}\text { embriók kezelése és } \\
\text { dsRNS injektálás }\end{array}$ & $\begin{array}{c}56 \\
(\mathrm{Sz}: 5,8)\end{array}$ & $\begin{array}{c}69,5 \\
(\mathrm{Sz}: 13,3)\end{array}$ & $\begin{array}{c}8,4 \\
(\mathrm{Sz}: 6,4)\end{array}$ & $\begin{array}{c}19,6 \\
(\mathrm{Sz}: 7,1)\end{array}$ & $\begin{array}{c}1,2 \\
(\mathrm{Sz}: 1,2)\end{array}$ \\
\hline nanos & $\begin{array}{l}\text { ivarsejt-specifikus } \\
\text { gén csendesítésének } \\
\text { hatása (pozitív } \\
\text { kontroll) }\end{array}$ & 67 & 59,7 & 52,5 & 19 & 21,0 \\
\hline
\end{tabular}

2. táblázat: Géncsendesítő kísérletsorozat kontrolljai. A kontrollkísérletekben az embrionális életképességre, illetve az ivarsejtekre és -szervekre gyakorolt hatást vizsgáltuk. A mutáns fenotípusok penetranciáját százalékban tüntettük fel. Sz: szórás.

Kontrollkísérleteink eredményei szerint az embriók kezelése és injektálása nagymértékben hatással volt azok életképességére, azonban a túlélő embriókban, illetve az azokból kifejlődő felnőtt állatokban az ivarsejtekre, illetve -szervekre gyakorolt hatás jelentősen kisebb a nanos dsRNS injektálásához képest. Az injektált állatokban (pufferel injektált kontroll, embrinális korban ki nem fejeződő gének csendesítése) $8,4-15,1 \%$-os gyakorisággal fordult elő ivarsejteket érintő rendellenesség embrionális korban. Ezt azzal magyarázzuk, hogy a korai embrióban, ahol még sejthatárok nem alakultak ki, a mikroinjektálás során olyan citoplazma- 
áramlásokat idézünk elő, melyek az ivarsejtek kialakulásához és fejlődéséhez szükséges, poszterior részen lokalizált faktorokat elsodorják helyzetükből. Az injektált negatív kontrollokban mért ivarsejt fenotípusok penetranciáját ezért a módszer hátterének tekintettük, és csak ennél az értéknél legalább kétszer magasabb gyakorisággal megfigyelt fenotípusokat fogadtunk el pozitív találatként. Az embrióban ki nem fejeződő gének (CG11320, CG15035, CG7442, Ance-3, CG13744, CG3339, AlCR2) csendesítésével bizonyítottuk, hogy az ivarsejtekben ki nem fejeződő mRNS-ekkel homológ dsRNS-nek nincsen számottevő hatása a ivarsejtek és -szervek fejlődésére (2. táblázat, 9. ábra).

\subsubsection{A géncsendesítő kísérletsorozat eredménye}

Kísérletsorozatunkban 502 gént vizsgáltunk úgy, hogy génenként átlagosan 60, és összesen 32500 embriót injektáltunk a Heidelberg2 dsRNS gyüjteményből származó géncsendesítő dsRNS-sel. Azokat a géneket tekintettük pozitív találatnak, melyek csendesítésénél a pufferoldattal injektált kontrollnál mért fenotípus aránynál legalább kétszer erősebb (30\%) ivarsejt fenotípus penetranciát tapasztaltunk embrionális korban. Végül 55 gén felelt meg ennek a kritériumnak. Kísérleteink során 18 gén csendesítése okozott a pufferrel injektált kontrollkísérletben tapasztaltnál (48,7\%-os penetrancia) erősebb embrionális letalitást. Az erős letalitás feltehetően a célgének szomatikus sejtekben bekövetkező csendesítésének tudható be, amit az is alátámaszt, hogy a 18-ból öt génnek (Cyclin B, arrest, Sec61 $\alpha$, punt, Myelodysplasia) ismert recesszív embrionális letális, funkcióvesztéses allélje is.

In vivo kísérletsorozatunk lehetőséget adott arra is, hogy az ivarsejtek és ivarszervek fejlődését ne csak embrionális szinten vizsgáljuk. A video-mikroszkópiás megfigyelést követően az embriókat táptalajra helyeztük, és a táptalajon kifejlődő 
állatok ivarszerveit kifejlett korban vizsgáltuk. 14 olyan gént találtunk, amely csendesítésénél egyetlen egyed sem jutott el felnőtt korig. Ez lehetett a géncsendesítés hatása, de okozhatta az is, hogy a táptalajra helyezett embriók kiszáradtak, vagy egyéb mechanikai sérülést szenvedtek. A túlélési arányokból ezért következtetést nem vontunk le. A felnőttkori fenotípusok meghatározásához összesen 8387 túlélő példányt boncoltunk fel.

Kétféle erősségü, a vad típustól eltérő, csökevényes ivarszervet eredményező fenotípust figyeltünk meg, mindkettő esetén hiányoztak a felnőttkori ivarszervekből a csíravonal eredetű ivarsejtek. Az enyhébb expresszivítású fenotípus esetében ez csak a páros ivarszerv egyik, míg az erősebb expresszivítású fenotípus esetében mindkét felében megfigyelhető volt. A mindkét ivar egyedeit felboncoltuk, és kiszámítottuk a mutáns fenotípust mutató ivarszervek elöfordulási gyakoriságát (csökevényes ivarszerv/összes ivarszerv).

A kontrollkísérletek eredményei (10. ábra és 2. táblázat) azt mutatják, hogy az embriók mikroinjektálása alacsony penetranciával $(0-3,6 \%)$ okozott csökevényes ivarszerv fenotípust kifejlett állatokban, ezért ezt az értéket is a módszer hátterének tekintettük, és csak az ennél legalább kétszer magasabb (8\%) penetranciájú ivarsejthiányos fenotípust mutató géncsendesítéseket tekintettük pozitív jelöltnek. Végül 77 gén csendesítése eredményezett 8\%-nál magasabb penetranciájú felnőttkori fenotípust. Az embrionális és adult rendellenes ivarsejt fenotípusok alapján 108 gént választottunk ki további vizsgálatra. Ezek közül 19 gén csendesítésénél figyeltünk meg mind embrionális, mind kifejlett korban is küszöbérték feletti rendellenes fenotípus penetranciát, 31 gén esetében csak embrionális, 58 esetben pedig csak felnőttkori ivarsejt- vagy ivarszerv-fenotípust észleltünk. 


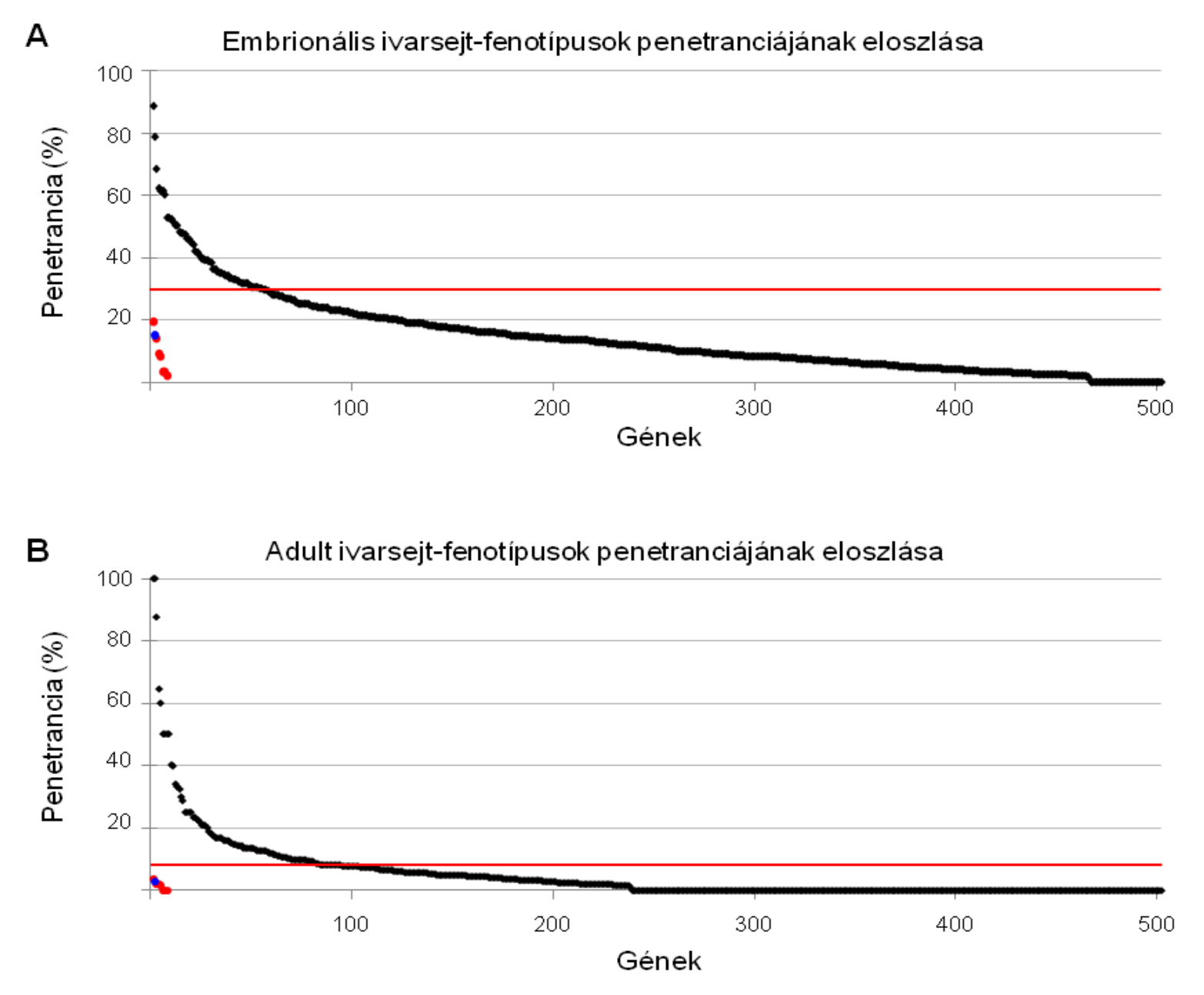

10. ábra: A génspecifikus dsRNS-ek injektálásával mért fenotípusok penetranciájának eloszlása embrionális (A) és adult korban (B). A csendesítéseket akkor ismételtük meg, ha az adott dsRNS csendesítésével embrionális, vagy adult korban a pufferrel injektált kontrollnál (Kék pont) legalább kétszer erősebb fenokópiát (piros határvonal) kaptunk. Fekete négyzet: embrionális ivarsejtekben kifejeződő, vizsgált gének csendesítésével előidézett fenotípusok penetranciája; Piros pont: embrióban nem expresszálódó gének (indifferens kontrol). A gének mindkét grafikonon a géncsendesítési kísérletsorozatban tapasztalt fenotípusok penetranciája alapján vannak sorbarendezve.

\subsubsection{A géncsendesítő kísérletsorozat technikai ismétlése}

A megvizsgált 502 gén csendesítése során 108 esetben tapasztaltuk, hogy a géncsendesítés a kontrollnál legalább kétszer nagyobb mértékben okozott ivarsejtfejlődési hibákat. Ezek közül 105 gén esetében a géncsendesítési kísérleteket megismételtük. A megismételt kísérletek során 17 esetben figyeltünk meg határérték 
feletti gyakorisággal mutáns embrionális és adultkori ivarsejt fenotípust, míg 20 esetben csak embriókban, és 22 esetben csak kifejlett állatokban. Összesen tehát 59 gén esetében tapasztaltunk reprodukálható ivarsejt-fejlődési rendellenességet.

\subsubsection{A géncsendesítő kísérletsorozat ismétlése új dsRNS-ekkel}

Arra az 59 génre, melyek csendesítésével reprodukálható fenotípusokat értünk el, új géncsendesítő dsRNS-eket terveztünk, és szintetizáltunk. Az új géncsendesítő dsRNSek tervezésénél fontos szempont volt, hogy célszekvenciájuk ne fedjen át az előzőekben alkalmazott dsRNS-ekével, és ezzel kizárjuk az esetleges közös off-target hatást. A dsRNS tervezésnél figyelemebe vettük, hogy az lehetőleg a mRNS olyan kódoló szakaszával legyen komplementer, amelyet az összes, a FlyBase adatbázisban jósolt splice-variáns tartalmaz. Három kivételtől eltekintve az összes génre sikerült a kritériumoknak megfelelő dsRNS-t előállítanunk. Két esetben a dsRNS szintézis sikertelen volt, míg a $C G 7271$ gén a szomszédos terminus génnel olyan nagyfokú hasonlóságot mutatott, hogy csak mindkét gént csendesítő szekvenciarészletet lehetett kijelölni. Ezután az 57 gén csendesítését az előző kísérletsorozathoz hasonlóan újra megismételtük. Négy gén (nos, Tre1, polar granule component (pgc), mei-P26) esetében az újratervezett dsRNS-ekkel történő géncsendesítés technikai ismétlése kísérleti hiba miatt sikertelen volt, a vizsgálandó állatok elpusztultak. Az 57 gén csendesítési kísérleteinek összes video-mikroszkópiás felvételét, beleértve a Heidelberg2 gyüjtemény dsRNS-eivel végzett kísérleteket is, újra kiértékeltük. A felvételek elemzése során a szubjektív megítélés hibalehetőségeit igyekeztünk minimálisra csökkenteni egyrészt úgy, hogy jól elkülöníthető fenotípus-kategóriákat határoztunk meg, melyek valamelyikébe az összes vad típustól eltérő fenotípust be 
tudtuk sorolni; másrészt úgy, hogy az összes kiértékelést egy személy végezte (H.L.).

A teljes géncsendesítő kísérletsorozat lépéseit a 11. ábra mutatja be.

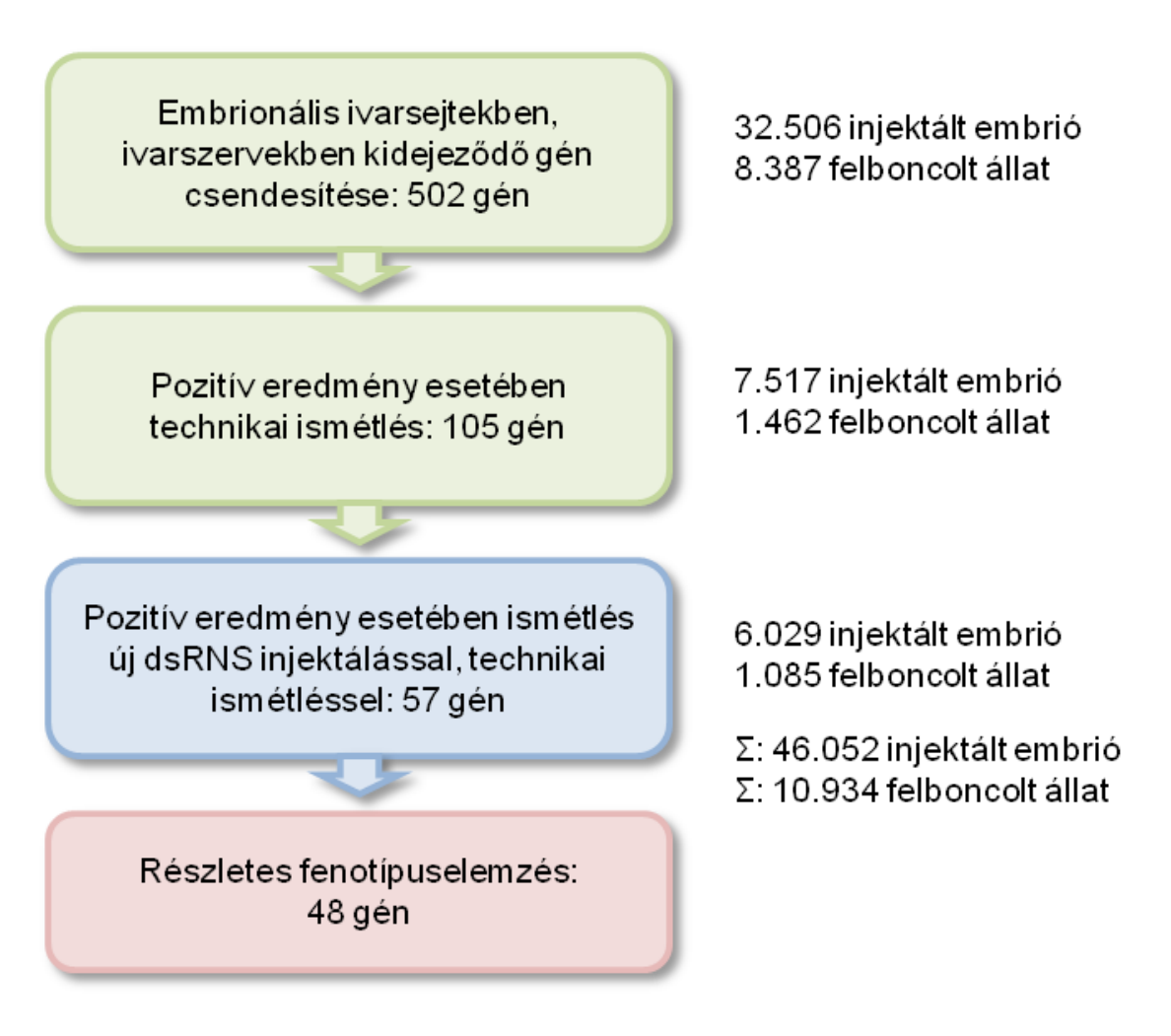

11. ábra: A géncsendesítő kísérletsorozat menete. A kísérletsorozatban 502 gént csendesítését végeztük el. Embrionális és adult ivarsejt-fenotípusok azonosítása esetén a kísérleteket megismételtük (105 gén). Azon génekre, melyek csendesítésével a fenotípusok ismételhetőek voltak (57 gén) új dsRNS-eket terveztünk, és szintetizáltunk, majd ezekkel is elvégeztük a kísérleteket és ismétlésüket. Ezen gének minden csendesítéséből származó kísérleti eredményét újra elemeztük, fenotípus kategóriák szerinti, részletes fenotípuselemzésnek vetettük alá. Végül 48 olyan gént azonosítottunk, melyek csendesítésével ismételhető ivarsejt fenotípust idéztünk elő. Az ábra jobb oldalán a kísérletsorozatban megvizsgált állatok (embriók és kifejlett állatok) száma látható.

\subsubsection{Az embrionális ivarsejt-fenotípusok kiértékelése}

A video-mikroszkópiás felvételek újraértékelése során a vad típustól eltérő ivarsejt-fenotípusokat a következő típusokba soroltuk: csökkent ivarsejtszám, bélkezdeményben maradó ivarsejtek, eltévedő ivarsejtek, embrionális ivarszerv hibás 
összerendeződése, embrionális ivarszervek hiánya. Az injektált embriókat felnevelve, a felnőtt állatok ivarszerveit felboncolva megállapítottuk azok mutáns fenotípusának (csökevényes ivarszerv) penetranciáját. Az embrionális ivarsejt-fenotípusok előfordulási gyakoriságát a filmezési folyamat végéig életben maradt embriók számához arányítottuk. Az ivarsejt-fenotípus penetranciáját a pufferel injektált kontrollnál mért értékekhez hasonlítottuk.

A géncsendesítési kísérletsorozatok jelöltjeinek azokat a géneket fogadtuk el, amelyeknél az ivarsejt-fejlődés hibáit reprodukálható módon tudtuk kimutatni. A reprodukálhatóság kritériuma az volt, hogy egy gén csendesítésével a független kísérletek során a kísérletek több, mint felében (4-ből 3, vagy 3-ból 2) a kontrollnál mért átlagos penetranciánál magasabb legyen mutáns fenotípusok előfordulása, és az átlagos ivarsejt-fenotípus penetranciája a kontroll átlagának legalább kétszerese legyen. A háromszoros illetve négyszeres ismétlések részletes fenotípus-elemzései során 48 gén csendesítése okozott a hatféle fenotípus kategória valamelyikében reprodukálható fenotípust (Függelék 3. táblázat).

\subsubsection{Csökkent ivarsejtszám}

A ,csökkent ivarsejtszám” fenotípus kategóriába soroltuk azokat az embriókat, melyekben embriogenezis negyedik stádiumában a vad típusnál lényegesen kevesebb ivarsejt füződik le, vagy a vad típusnak megfelelő számban lefüződő ivarsejtek nem osztódnak. A „,csökkent ivarsejtszám” fenotípus a 10. stádiumban könnyen azonosítható, mikor a bélkezdeményből jóval kevesebb ivarsejt kerül a testüregbe (12. ábra). Ez a fenotípus a pufferel injektált embriókban átlagosan 1,21\%-os gyakorisággal jelent meg. A kontroll értéket kétszeresen meghaladó penetranciájú fenotípust 17 gén csendesítésével tudtuk kimutatni reprodukálható módon. Közülük a 
legnagyobb penetranciájú fenotípust a polar granule component (pgc) (30,3\%), a nanos (nos) (25,0\%) és a mei-P26 (21,3\%) gének csendesítése mutatta. A nos és pgc gének embrionális ivarsejtek kialakulásában betöltött szerepe már korábban is ismert volt $[28,72]$. A „csökkent ivarsejtszám” fenotípussal azonosított 17 gén embrionális kifejeződési mintázata a fenotípussal jó megfelelést mutat, hiszen a 17 gén közül 10 esetben a mRNS-ek génexpressziós adatbázisok alapján az ivarplazmában magas expressziót mutatnak, hat esetben pedig egyenletes mRNS-eloszlás figyelhető meg a korai embriókban (Függelék 4. táblázat).

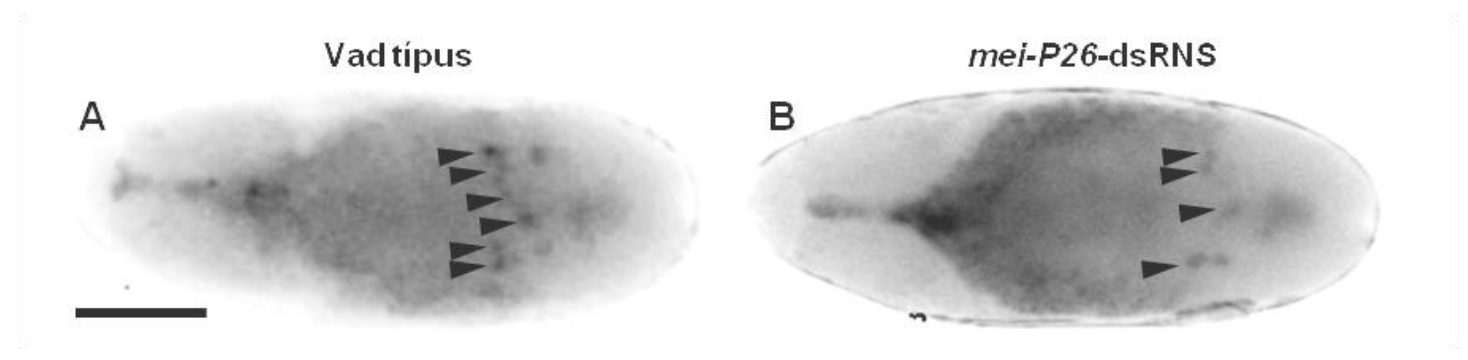

12. ábra: A „csökkent ivarsejtszám” fenotípus. A felvételek az embrionális fejlődés 10 . stádiumában készültek. Mérték: $100 \mu \mathrm{m}$. A: pufferrel injektált kontroll (vad típus). B: A mei-P26 gén elleni dsRNSsel injektált embrióban az embrionális ivarvonalsejtek (fekete nyílhegy) száma kevesebb, mint a vad típusban.

\subsubsection{Középbélkezdeményben maradó ivarsejtek}

A „középbél-kezdeményben maradó ivarsejtek” fenotípusa az embrionális fejlődés 10. stádiumának végén figyelhető meg, amikor az ivarsejtek egy része nem képes a középbél-kezdemény falán áthatolni (13. ábra). A bélben maradt sejtek általában még az embriogenezis végén is kifejezték a nos-Moe-EGFP fluoreszcens markergént, ami lehetővé tette a fenotípus könnyü felismerését. A középbélkezdeményben maradó ivarsejt fenotípus a szúratlan kontroll embriókban is 2\%-os gyakorisággal fordult elő, a pufferrel injektált embriókban a fenotípus penetranciája pedig átlagosan 4,2\%-os volt. Ebben, a leggyakrabban előforduló fenotípus 
kategóriában 25 gén felelt meg a reprodukálható mutáns fenotípus kritériumának. A legmagasabb értékeket a Trapped in endoterm 1 (Trel) gén csendesítésével értük el (57,5\%), mely nevét is a gén mutáns alléljának hasonló fenotípusáról kapta [14].

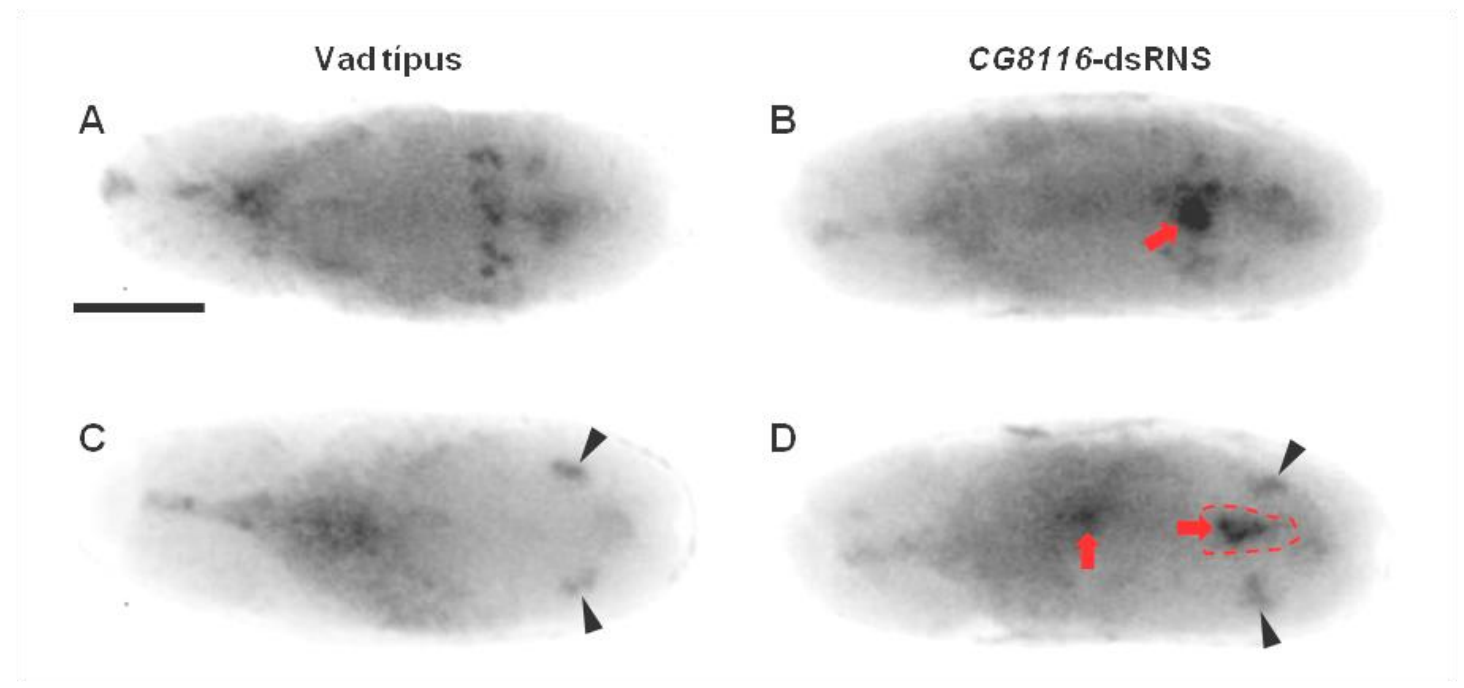

13. ábra: A „középbél kezdeményben maradó ivarsejtek” fenotípus. A felvételek az embrionális fejlődés 10. (A-B) és 14 stádiumában (C-D) készültek. Az embrionális ivarszerv-kezdeményeket fekete nyílhegyek jelzik. Mérték: $100 \mu \mathrm{m}$. A, C: pufferrel injektált kontroll embriók (vad típus). B, D: a CG8116 gén elleni dsRNS-sel injektált embriókban az embrionális bélkezdeményben (piros szaggatott vonal) rekedő ivarvonalsejtek (piros nyíl) figyelhetők meg.

A bélben maradó ivarsejt fenotípus gyakran társul későbbi rendellenességekkel, ami arra utal, hogy az ivarsejtek bélfalon történő átjutásának megfelelő időintervallumban kell megtörténnie. Azok az embrionális ivarsejtek, melyek ebben a transzepiteliális átkelésben késést szenvednek, lemaradhatnak az embrionális ivarszerv-kialakulásról. A bélfalon késedelmesen áthaladó ivarsejteket a video-mikroszkópiás analízis során a testüregben eltévedő ivarsejtekként azonosítottuk. A két fenotípus közötti összefüggést Stein és munkatársai a slow as molasses (slam) mutáns esetében már kimutatták [73]. Kísérleteink során a bélben maradó fenotípust mutató géncsendesítések közel kétharmadában figyeltük meg az ehhez kapcsolódó eltévedt ivarsejt fenotípust. Eredményeinket a génexpressziós adatbázisok RNS-lokalizációs adataival összevetve azt tapasztaltuk, hogy 7 gén idő- 
és térbeli kifejeződése (adenosine 2 (ade2), CG17658, CG8116, dunce (dnc), CG14545, Tre1 és eIF5) teljesen megfelel a fenotípusnak, hiszen a középbélkezdeményben elhelyezkedő ivarsejtekben mutatható ki a mRNS-ük. Tizenegy esetben a mRNS ivarsejt-specifikus kifejeződése az embrionális fejlődés során megelőzi a fenotípus megjelenését (Függelék 4. táblázat). A jelenség könnyen magyarázható azzal, hogy ezen gének transzlációja az embrionális fejlődés 10 . stádiumára megtörtént, mRNS-eik elbomlottak, tehát a géncsendesítő hatás a fenotípus megfigyelésének idejét megelőzően érvényesült. Két gén mRNS-ének a fenotípus megjelenése elötti előfordulásáról nincsen adatunk. Hat gén (doublesex $(d s x)$, Kinesin-like protein at $61 F(K l p 61 F)$, no child left behind (nclb), PHD finger protein 7 ortholog (Phf7), CG4281, CG13298) kifejeződése azonban meglepő módon ivarsejtekben feldúsuló mRNS eloszlási mintázatot csak az embrionális fejlődés későbbi szakaszában mutat. Korábban kimutatták, hogy e gének közül a többnek ( $d s x$, $K l p 61 F, n c l b, P h f 7)$ szerepe van az ivarvonal nemének meghatározásában [21,74,75]. Mivel e hat gén közül négy biztosan kifejeződik az embrionális fejlődés 8-10. stádiumában a középbél-kezdemény falában, elképzelhetőnek tartjuk, hogy e gének az ivarvonal nemének meghatározásához hasonlóan, egymással együttműködve, vesznek részt a bélfal átjárhatóságának biztosításában is. E feltételezés szerint e gének csendesítésének ebben a fejlődési stádiumban testi sejt-függő, közvetett hatása van az ivarsejtek fejlődésére. 


\subsubsection{Eltévedt ivarsejtek}

Az embrionális fejlődés 10. stádiumában az embrionális ivarsejtek átjutnak a bélkezdemény falán, ezután a testüregben, jobb-bal irányban két, nagyjából azonos mennyiségü sejtet számláló csoportra oszlanak, és az embrió dorzális oldala felé vándorolnak, ahol a szomatikus eredetü ivarszerv prekurzorokkal egyesülve, az embrionális fejlődés 14. stádiumában kialakítják az embrionális ivarszerveket. Vad típusú embriókban is megfigyelhető, hogy néhány (átlagosan 1,6) ivarsejt az embrionális gonádokhoz nem kapcsolódik, eltéved a testüregben [76]. Kísérleteink során azt tapasztaltuk, hogy a pufferrel injektált kontroll embriókban 8,1\%-os gyakorisággal találtunk olyan egyedeket, ahol kettőnél több ivarsejt tévedt el. 25 gén csendesítésével értünk el legalább kétszeres penetranciájú, reprodukálható fenotípust (14. ábra).

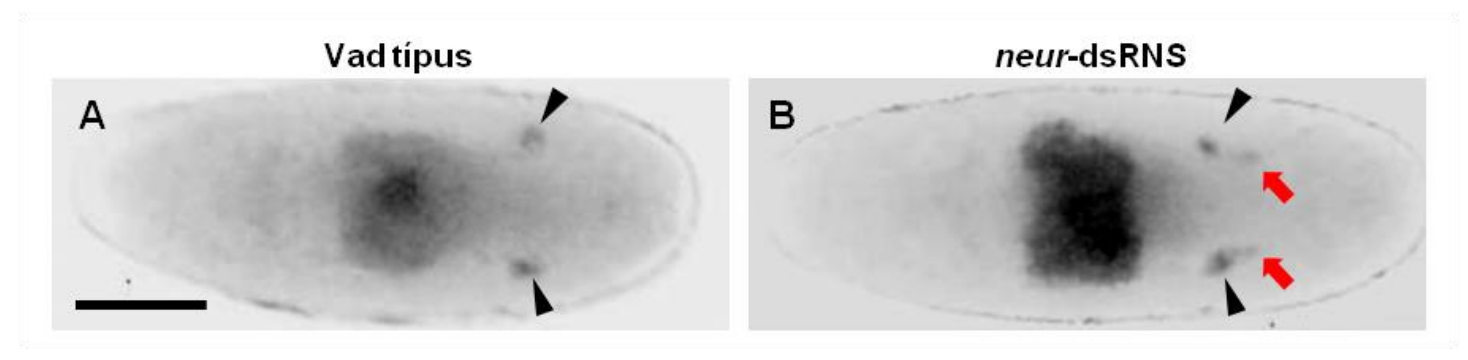

14. ábra: Az „,eltévedt ivarsejtek” fenotípus. A felvételek az embrionális fejlődés 14. stádiumában készültek. Az ivarszerv-kezdeményeket fekete nyílhegyek jelölik. Mérték: $100 \mu \mathrm{m}$. A: Pufferrel injektált embrió (vad típus). B: A neuralized (neur) gén elleni dsRNS-sel injektált embriókban az ivarszerv kezdeményhez nem kapcsolódó, eltévedt ivarvonal sejtek figyelhetőek meg (piros nyíl).

Drosophilában az embrionális ivarsejt-vándorlásnak eddig főként olyan faktorait írták le, melyek testi sejtekben fejeződnek ki. E gének szerepe főként vonzó és taszító jelmolekulák szintézisével, kibocsátásával, illetve a bélkezdemény falának átjárhatóságával kapcsolatos [76,77]. Csupán néhány esetben ismert, hogy ivarsejtspecifikus faktoroknak szerepe lenne a folyamatban [17,20]. Nem ismert például, 
hogy a vonzó és taszító szignálok milyen receptorokon keresztül fejtik ki hatásukat az embrionális ivarsejteken, illetve, hogy a sejtek ezekre a jelekre miként reagálnak. Kísérletsorozatunkban azonosított gének jelentős részének (25-ből 17) az ivarsejtvándorlásra gyakorolt hatása feltehetően közvetett, hiszen ezek csendesítése már a sejtek bélkezdeményböl való kijutására is hatással volt (ld. 4.1.9). Hét olyan gént (pebble (pbl), neur, porin, Phosphoglyceromutase (Pglym78), maelstrom (mael), knirps-like (knrl), Aosl) is azonosítottunk, melyek csendesítése legkorábban az embrionális ivarsejt-vándorlásban mutatott rendellenességeket.

\subsubsection{Az embrionális ivarszerv-kezdemény kialakulásának hibája}

Az embrionális ivarszervek kialakulása a 14. embrionális stádiumra fejeződik be. A folyamat alatt testüregben vándorló ivarsejtek az embrió dorzolaterális részére kerülnek, ahol szoros kapcsolatot létesítenek a 10., 11. és 12. paraszegment mezodermájából származó, szomatikus ivarszerv-prekurzor sejtekkel. A folyamatban szerepet játszó gének közül eddig főként olyanokat azonosítottak, melyek feltehetően a szomatikus ivarszerv-prekurzorsejtek adhéziós tulajdonságaiért felelősek [28,72].

Az „ivarszerv-kialakulás hibája” fenotípus kategóriába soroltuk azokat az embriókat, melyekben az ivarszervet alkotó szomatikus- és az ivarsejtek szoros kapcsolódása, a kompakt ivarszerv kialakulása zavart szenved (15 ábra). Ezt a fenotípust injektálatlan és pufferel injektált embrióknál egyáltalán nem figyeltük meg, azonban nyolc gén ( $p b l$, neur, Tre 1, CG7271, Thiolase, pgc, nos, ovo) csendesítésnél reprodukálható módon, bár alacsony penetranciával (3-10,4\%) kimutatható volt. Megfigyeléseink szerint túl alacsony ivarsejtszám esetén (2-4/ivarszerv) az ivarszerv kialakulás gyakran hibát szenved. A kisszámú ivarsejt ugyan eljut az ivarszerv formálódás helyére, de a szomatikus ivarszerv-prekurzorokkal nem képes kompakt 
ivarszerveket kialakítani. Elemzéseink szerint a fenotípus gyakran csökkent ivarsejtszámmal, mint okkal és embrionális vagy felnőttkori ivarszerv-hiánnyal, mint következménnyel jár együtt.

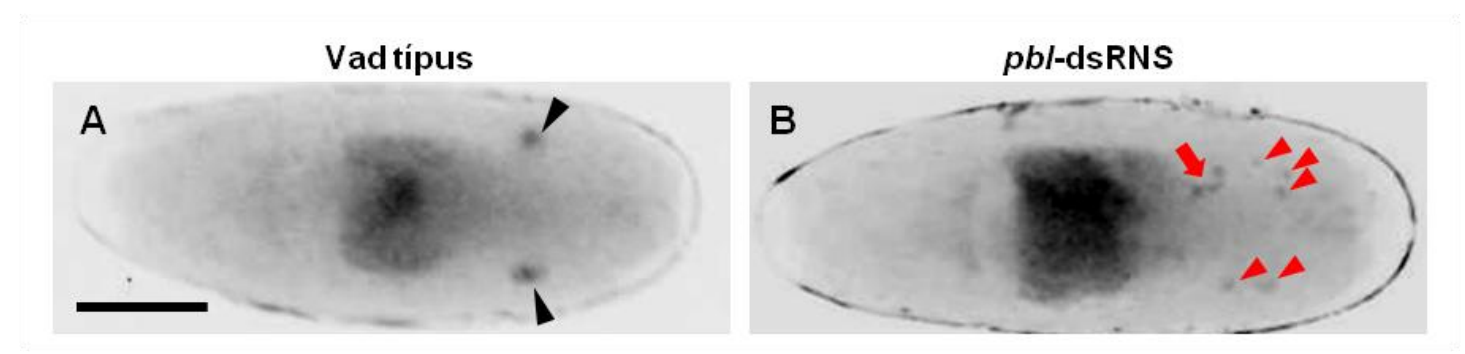

15. ábra: Az „ivarszerv-kezdemény kialakulásának hibája” és az „embrionális ivarszerv hiánya” fenotípusok. A felvételek az embrionális fejlődés 14. stádiumában készültek. Az ivarszervkezdeményeket fekete nyílhegyek jelölik. Mérték: $100 \mu \mathrm{m}$. A: Pufferrel injektált embrió (vad típus). B: A $p b l$ gén elleni dsRNS-sel injektált embrió jobb oldali (felső) ivarszerv-kezdeményének kialakulása hibás. Habár az embrionális ivarvonal-sejtek megfelelő helyen vannak, azok nem kapcsolódnak szorosan egymáshoz (piros nyíl), mint a vad típusban. A bal oldali (alsó) ivarszerv kialakulásának helyén ivarvonalsejtek egyáltalán nem figyelhetőek meg. Az embrióban eltévedt ivarvonalsejtek is láthatók (piros nyílhegy).

\subsubsection{Embrionális ivarszervek hiánya}

Az „embrionális ivarszervek hiánya” fenotípust az jellemzi, hogy az embrionális fejlődés 14. stádiumára nem alakulnak ki az embrionális ivarszervek (15. ábra). A fenotípus több okra vezethető vissza. Természetesen nem alakulhat ki ivarszerv, ha ivarsejtek egyáltalán nincsenek, vagy azok mind a középbélkezdeményben ragadnak, vagy eltévednek. Ebbe a kategóriába soroltuk azokat az embriókat, amelyekben a bél-kezdemény falán áthatoló ivarsejtek a testüregben való vándorlás során eltünnek. Géncsendesítéses kísérletsorozatunk során 12 gén esetében tapasztaltuk az embrionális ivarszervek hiányát 4,6-56,4\%-os gyakorisággal. A kísérletsorozatban használt negatív kontrollok esetében ivarszervhiányos fenotípust egyáltalán nem figyeltük meg. A géncsendesítések közül legmagasabb penetrancia értéket a Trel gén csendesítésével értük el, mely esetben a fenotípus teljes mértékben 
magyarázható azzal, hogy az összes embrionális ivarsejt a bélkezdeményben ragadt, így az ivarsejtek meg sem érkeztek az ivarszerv kialakulás helyszínére, ezért ép ivarszerv sem alakulhatott ki. A nos gén csendesítése esetén gyakran megfigyeltük, hogy a testüregben vándorló, nos-Moe-EGFP fluoreszcens fehérjét kifejező ivarsejtek eltünnek. Ez egybevág azzal a korábbi eredménnyel, mely szerint az anyai nanos RNS hiányos embriókban az ivarsejtek vándorlásuk, és ivarszervekbe rendeződésük során apoptózissal elpusztulnak, vagy elvesztik ivarvonali identitásukat [78].

\subsubsection{Csökevényes ivarszervek kifejlett állatokban}

A felnőttkori, kiboncolt ivarszervek vizsgálatánál a csökevényes ivarszervek kétféle expresszivitású fenotípusát figyeltünk meg: a páros ivarszerv mindkét fele, vagy csak egyik fele volt csökevényes. Korábbi megfigyeléseink alapján úgy gondoljuk, hogy a teljes és féloldali csökevényes ivarszerv fenotípus ugyanazon okoknak lehetnek különböző mértékü következményei [49]. Reprodukálható csökevényes ivarszerv fenotípust összesen 23 gén csendesítése esetén figyeltünk meg. Számos gén csendesítése esetében e késői fenotípus a korábbi fenotípusok következményének tudhatók be. Például a nos és $p g c$ csendesítése esetén hasonló arányban figyeltünk meg felnőtt és embrionális korban csökevényes ivarszervet, illetve ivarszerv-hiányt. Megfigyeltünk azonban olyan eseteket is, melyeknél a kifejlett állatokban tapasztalt csökevényes ivarszerv fenotípust nem elözték meg az embrionális ivarsejtek és ivarszervek hibái (spire (spir), Supressor of variegation 2-10 (Su(var)2-10), Supressor of variegation 205 (Su(var)205), fascetto (feo) csendesítése), vagy azok csak kisebb mértékben voltak kimutathatóak (mei-P26). Úgy gondoljuk, hogy ezen gének az ivarszervek fejlődésének, lárvális vagy bábkori szakaszában játszanak fontos szerepet. Az a megfigyelés, hogy a géncsendesítő dsRNS-ek korai 
embriókba történő injektálása embrionális kornál később okoz azonosítható fenotípust arra utal, hogy az embrióba juttatott dsRNS-ek nagyon stabilak. Megfigyelésünket korábbi adatok is alátámasztják. Misquitta és munkatársai a white gént embrióban, dsRNS injektálásával csendesítették, és a kifejlett állatok szemében 3\%-os penetranciával figyeltek meg mutáns fenotípust [79].

A redundáns funkciójú, az életképesség szempontjából esszenciális gének esetében számolnunk kellett azzal az eshetőséggel, hogy a korai embriókban végzett géncsendesítés az állatok pusztulását okozhatja, ezért e gének késői, ivarsejtspecifikus hatása nem kimutatható. A kísérletsorozat 48 jelöltje közül a belle (bel), Klp61F, neur, Cyclin A (CycA), CycB, pbl, Aos1 és myoblast city (mbc) gének csendesítésénél figyeltünk meg gyakori, teljes kifejlődés előtti letalitást. E gének mindegyikének ismert embrionális, lárvális vagy báb letalitást okozó funkcióvesztéses allélja (FlyBase). Az említett nyolc gén csendesítésének hatását a kifejlett állatok ivarszervében ezért nem tudtuk megvizsgálni.

\subsubsection{Jelölt gének rendszerezése fenotípusaik alapján}

Kísérletsorozatunkban egy-egy gén csendesítésekor leggyakrabban többféle fenotípust is megfigyeltünk. Egy-egy fenotípus megjelenésén túl az is jelentőséggel bír, hogy az adott fenotípusok milyen gyakorisággal fordulnak elö. A hasonló fenotípus-mintázatot mutató géncsendesítések esetén elképzelhető, hogy a célgének egymással együttműködve, azonos fejlődési lépésekben vesznek részt. A jelölt gének

csendesítésével kapott, ismételhető penetrancia értékeinek átlagát fenotípus kategóriánként táblázatba foglaltuk. A vizsgált gének csendesítésével kimutatott fenotípus-mintázatokat a hierarchikus klaszterezés módszerével hasonlítottuk össze. A 
eljárás lényege, egyes géneket fenotípus eloszlásuk és -gyakoriságuk szerint kládokba rendezzük. A fenotípus mintázatok hasonlósága kladogrammon jeleníthető meg.

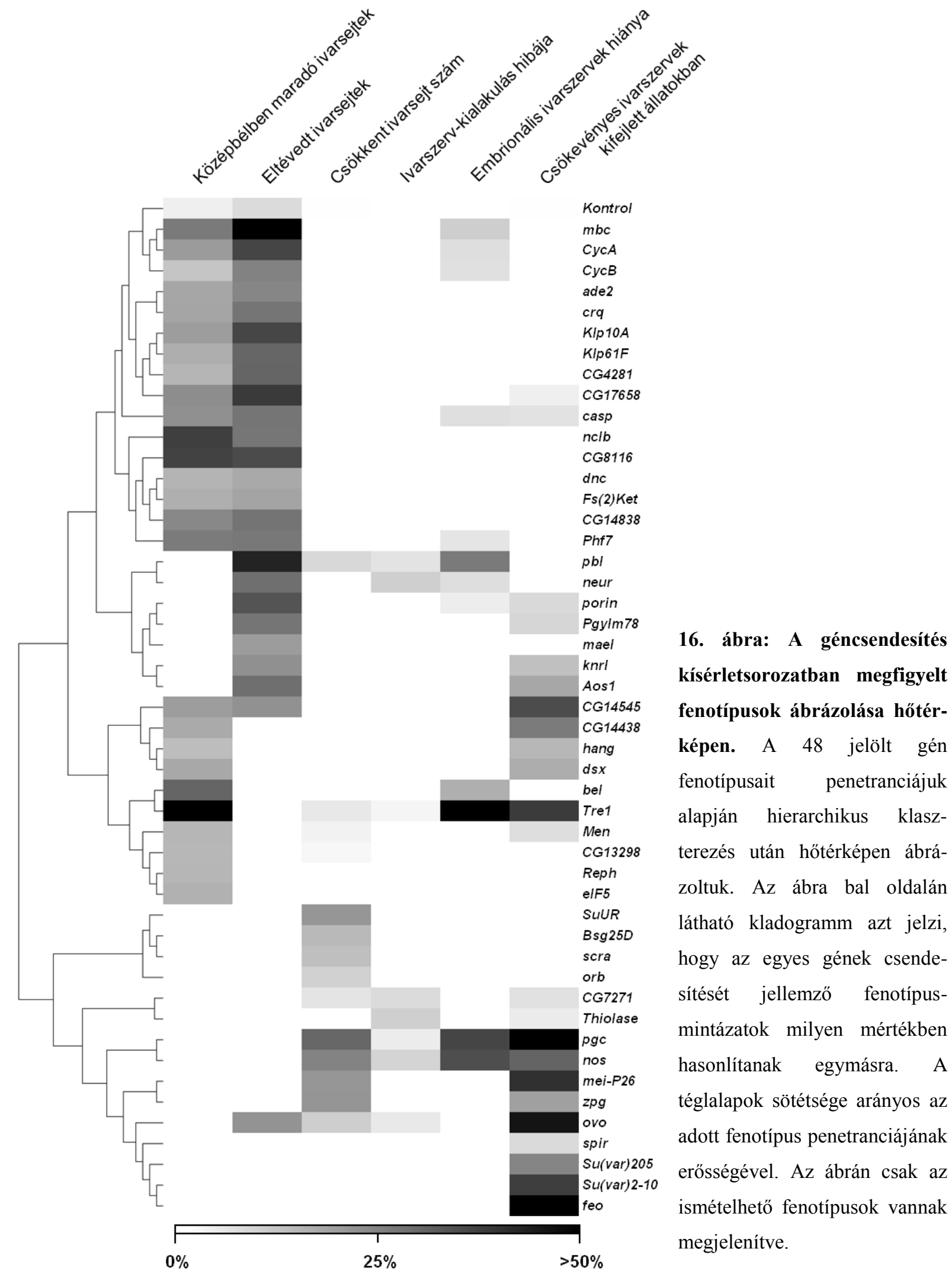


A hierarchikus klaszterezéssel csoportosított fenotípus-mintázatokat a fenotípusok penetranciájának erősségét bemutató hőtérképen ábrázoltuk (16. ábra). Ez az ábrázolásmód segíti a fenotípus kategóriák összefüggéseinek bemutatását, illetve az azonos fenotípus-mintázatot mutató géncsendesítések azonosítását.

\subsection{Az ivarsejt transzkriptóma redundanciájának vizsgálata}

A géncsendesítő kísérletsorozatunkban vizsgált több mint ötszáz ivarvonalban kifejeződő génnek kevesebb, mint tizede mutatott ismételhető, mutáns ivarsejt vagy ivarszerv fenotípust embrionális vagy adult korban. Kézenfekvő kérdés, hogy az ivarsejtekben kifejeződő gének nagy részének csendesítése miért nem okoz zavart az ivarsejtek fejlődésében? Erre a kérdésre logikus válasz lehet, hogy az ilyen ivarvonalspecifikus géntermékek redundánsak, tehát egy kieső fehérje funkcióját egy másik, hasonló fehérje képes ellátni. Annak eldöntésére, hogy ez a feltételezett helyettesítő mechanizmus mennyire érvényesül a Drosophila embrió ivarvonalában, a hasonló fehérjéket kódoló géneket párosával csendesítettük. A fehérjék hasonlóságának meghatározásához három módszert használtunk. Az 502 ivarvonal-specifikus fehérje aminósav-sorrendjének hasonlóságát ClustalW algoritmus segítségével állapítottuk meg (Score $\geq 15$ ). A hasonló doméneket tartalmazó fehérjéket az Uniprot fehérjeadatbázis segítségével térképeztük fel. A közös eredetü géneket (paralógok) az Ensembl adatbázis alapján azonosítottuk. A különböző módszerekkel meghatározott génpárokat tartalmazó listák között átfedések is voltak, melyet az 17. ábra mutat be. 


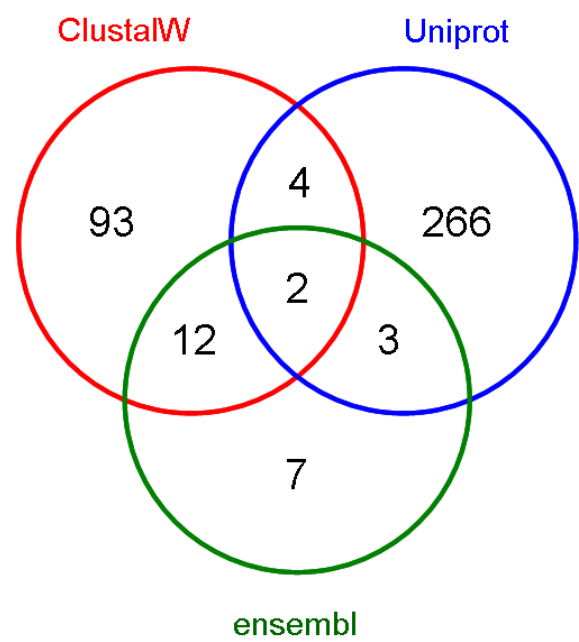

17. ábra $\mathrm{Az}$ ivarsejt-specifikus transzkriptóma hasonló fehérjéi. Fehérjeszekvencia hasonlóság alapján (ClustalW) 111 génpárt, azonos doménszerkezetek (Uniprot) alapján 275 génpárt, közös eredet (Ensembl) alapján 24 génpárt választottunk ki vizsgálatra.

Összesen 387 génpárt vizsgáltunk meg kettős géncsendesítéssel. Mivel a kettős géncsendesítésnél kétszeres koncentrációjú dsRNS-t juttatunk be az embriókba, ellenőriznünk kellett, hogy a megemelt dsRNS mennyiség nem okoz-e aspecifikus fenotípust. Kontrollként a galectin dsRNS-nek a kettős géncsendesítés esetében alkalmazott $2 \mu \mathrm{g} / \mu 1$ töménységü oldatát használtuk. A galectin gén RNS-terméke embrionális ivarsejtekben kifejeződik, de csendesítése mutáns fenotípust nem okoz. A $2 \mu \mathrm{g} / \mu \mathrm{l}$ töménységü dsRNS oldat injektálása nem okozott a korábbi géncsendesítő kísérletek kontrolljainál magasabb aspecifikus ivarsejt fenotípust sem embrionális $(11,6 \%)$, sem adult korban $(0 \%)$.

Azonos funkciót ellátó gének kettős csendesítésétől azt vártuk, hogy a kettős csendesítés magasabb penetranciájú fenotípust adjon, mintha a génpár tagjainak önmagukban való csendesítését független eseményként vizsgálnánk. Amennyiben a génpár csendesítése egymástól független esemény, akkor a következőképpen lehet kiszámolni az elvárt fenokópiák előfordulási gyakoriságát ( $\left.\mathrm{f}_{\text {várt }}\right)$ :

$$
\mathrm{f}_{\text {várt }}=1-\left(1-\mathrm{f}_{1}\right)\left(1-\mathrm{f}_{2}\right)
$$

A képletben $f_{1}$ a génpár egyik tagja által adott mutáns fenotípus penetranciája (tehát az 1- $\mathrm{f}_{1}$ a vad fenotípust mutató egyedek aránya), míg $\mathrm{f}_{2}$ a génpár másik tagja által 
mutatott mutáns fenotípus arány. Kettős géncsendesítésünk során azokat a génpárokat tekintettük jelöltnek, ahol a mért mutáns fenotípus penetrancia magasabb volt a képlet alapján elvárttól $\left(\mathrm{f}_{\text {mért }}>\mathrm{f}_{\text {várt }}\right)$. Technikai ismétlés után két esetben figyeltük meg, hogy a génpár (Ras GTPase activating protein 1 (Gapl) és trio, illetve az La related protein (larp) és CG32486) csendesítése az elvártnál erősebb fenotípust mutat. A két génpárra új géncsendesítő dsRNS-eket terveztünk, majd a kísérleteket technikai ismétléssel elvégeztük, a video-mikroszkópiás felvételeket részletesen kiértékeltük, a megfigyelt fenotípusokat kategóriákba soroltuk. Az új dsRNS-sel történő ismétlésekben a larp és CG32486 kettős csendesítése nem okozott az egyes gének csendesítésénél erősebb fenotípust, azonban a Gapl és trio esetén a reprodukálhatóság továbbra is fennállt. A részletes fenotípus-analízis során fény derült arra, hogy a két gén együttes csendesítésnek hatására nagy arányban tévednek el az embrionális ivarsejtek $(59,8 \%)$ és gyakran ivarszerv-összerendeződési hibákat $(9,3 \%)$ is megfigyelhetünk (18. ábra). A trio egy Rho guanyl-nucleotid exchange factor (RhoGEF) fehérjét, míg a Gapl egy Ras aktiváló fehérjét (RasGAP) kódol [80,81]. A RhoA fehérjéről kimutatták, hogy az ivarsejtek bélfal-kezdeményen történő áthaladásában játszik szerepet, míg a RasGAPnak a Ras1 fehérje szabályozásán keresztül összetettebb szerepe van az embrionális ivarsejtek vándorlásában, fenntartásában $[14,17,82]$. Feltételezésünk szerint a trio és Gapl gén együttes csendesítése a RhoA és Ras1 kis GTPázok aktivitásának megváltozásán keresztül, egymástól molekuláris értelemben függetlenül ugyan, de mindketten az ivarsejtek vándorlásának szabályozásán keresztül fejtik ki hatásukat. Mikor a géneket egyesével csendesítettük, az ivarsejtek fejlődésében jelentős mértékü hatást nem figyeltünk meg, azonban két dsRNS együttes injektálását az embriók nem tudták tolerálni, az ivarsejtek fejlődése összeomlott. 
A Embrinálisivarsejtek hibái (összesen)

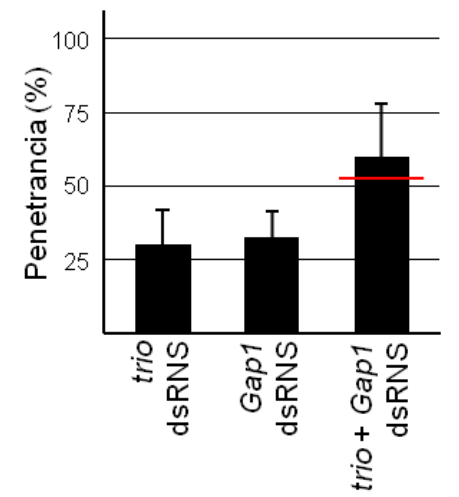

B

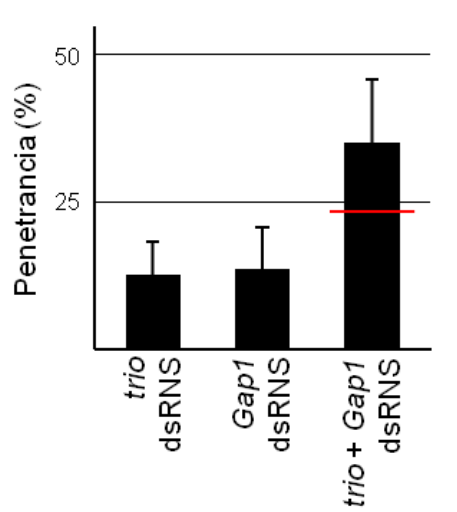

C Embrionális ivarszervek hiánya

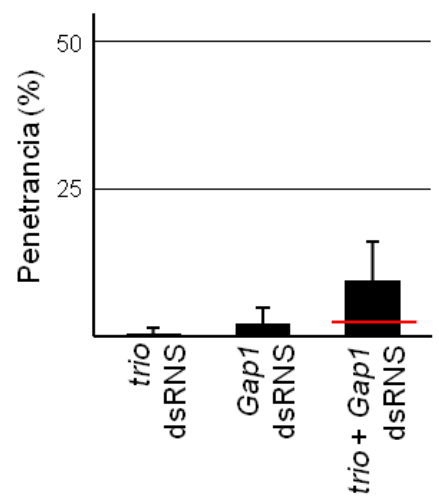

18. ábra A trio és Gap1 kettős csendesítésével megfigyelt embrionális ivarsejt fenotípusok. Az embrionális ivarsejt-fejlődésben megfigyelhető hibák (A) elsősorban két fenotípus komponensnek köszönhetőek: az eltévedt ivarsejteknek (B) és az ivarszervek hiányának (C). A kettős csendesítések diagramjain piros vonallal az $\mathrm{F}_{\text {várt }}$ értéket jelöltük.

A két GTPáz szabályozó fehérje génjétől eltekintve az ivarsejt transzkriptómában funkcionális redundanciára utaló jelet nem találtunk. A hasonló fehérjéket kódoló gének együttes csendesítése nem okozott reprodukálható módon rendellenességeket az ivarsejt-fejlődés során. Az ivarsejtekben kifejeződő gének funkcionális átfedésének alacsony szintje arra utal, hogy e fejlődési folyamatban fenotípusos robosztusság más módon valósulhat meg.

\subsection{A géncsendesítő kísérletsorozat eredményeinek megerősítése genetikai interakció módszerével}

Ha egy adott fejlődési folyamatért felelős géneket kívánunk feltérképezni, kézenfekvő módszer lehet, hogy a folyamat eddig ismert szabályozó elemeivel mutatunk ki genetikai kölcsönhatásokat. Az RNSi kísérletsorozat eredményeit egy ivarsejthiányos fenotípusra érzékenyített háttéren megnyilvánuló genetikai interakcióval kívántuk megerősíteni. Az általunk használt érzékenyített genetikai 
hátterü Drosophila törzs az ivarsejt kialakulásban kizárólag anyai hatású módon szerepet játszó három gén: a staufen (stau), az oskar (osk) és a TropomyosinII (TmII) funkcióvesztéses alléljait $\left(\operatorname{stau}^{D 3}, o s k^{54}, \mathrm{TmII}^{\mathrm{el4}}\right)$ heterozigóta formában hordozza. Az érzékenyített genetikai hátteret az alkalmazott allélok kezdőbetűiből kialakított betűszóval SOT rendszernek nevezzük. A hármas heterozigóta kombinációt hordozó állatok utódaiban alacsony penetranciájú, enyhe ivarsejthiányos fenotípus figyelhető meg. Az ivarvonalsejteket megjelölő Vasa-ellenanyag festés segítségével jellemeztük a SOT érzékenyítő allélokat hordozó állatok utódaiban az embrionális ivarsejtek fenotípusát. A SOT nőstényektől származó utódokban a 11. embrionális fejlődési stádiumban átlagosan 9 ivarsejtet számláltunk, míg vad típusú állatokban 21,1-et (19. ábra) Ha SOT háttérre, egy ivarsejt-kialakulásban, vagy -fejlődésben szerepet játszó gén funkcióvesztéses allélját bevisszük (négyszeres heterozigóta), akkor az utódgenerációban ivarsejthiányos fenotípus penetranciája megemelkedését várjuk [49].

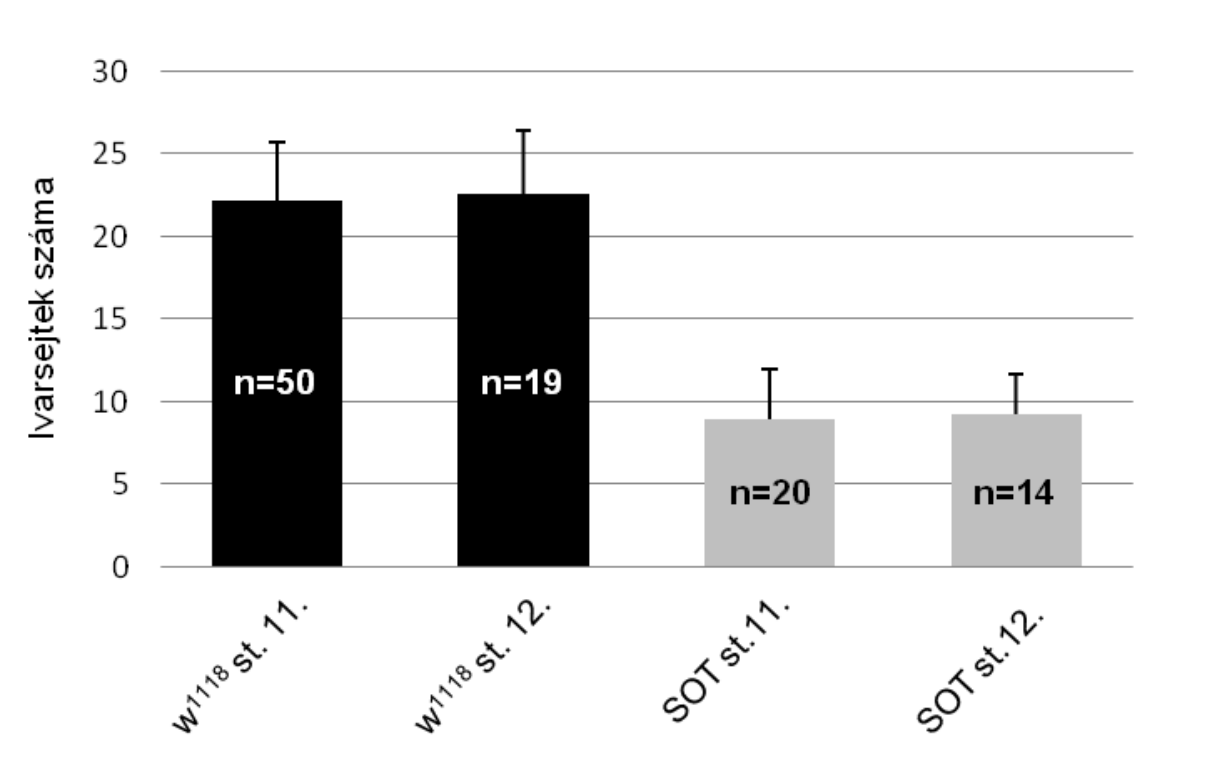

19. ábra: Az érzékenyített genetikai háttérként használt genotípusú (SOT) embrionális ivarsejtszáma a vad típusnál alacsonyabb. Vasa-ellenanyag jelöléssel kimutatható, hogy a $w^{1118}$; stau ${ }^{D 3}, c n^{2} / S M 6 b, c n^{2} ; s t,{ }^{1}$ osk ${ }^{54}, T_{m I I}{ }^{14} / T M 3 S b^{1}$, Ser $^{1}$ genotípusú nöstények utód embrióiban (SOT) az ivarsejtek száma jelentősen alacsonyabb, mint a vadtípusú $w^{1118}$ embriókban az embrionális fejlődés 11. és 12 . stádiumában. $\mathrm{p}<3,1 \times 10^{-13}$. n: vizsgált embriók száma. 
Az RNSi kísérletsorozatban azonosított gének alléljait megvizsgáltuk az ivarsejt-fejlődés szempontjából érzékenyített SOT genetikai háttéren. A RNSinterferencia kísérletsorozat jelölt génjeinek mutáns alléljait úgy választottuk ki, hogy lehetőleg bizonyítottan a gén funkcióvesztését idézzék elő. Mivel kevés jelölt gén rendelkezett jól jellemzett alléllal, a legtöbb esetben olyan allélt választottunk, amely a gén fehérje kódoló részét érinti. Amennyiben ilyen génmutáció sem volt elérhető, intronikus régiót, vagy feltételezett 5' szabályozó régiót érintő allélt választottunk. A kísérlet kontrolljaként a $w^{1118} ; \operatorname{stau}^{D 3}, c n^{2} / S M 6 b, c n^{2} ; s t^{1}{ }^{1}$ osk ${ }^{54}, \mathrm{TmII}^{e 14} / \mathrm{TM} 3 \mathrm{Sb}^{1}$, $\operatorname{Ser}^{1}$ genotípusú nőstényeket vadtípusú $w^{1118}$ hímekkel kereszteztük. A kikelő szüz $w^{1118} ; \operatorname{stau}^{D 3}, \mathrm{cn}^{2} /+o s k^{54}, T m I^{e 14} /+$ genotípusú nőstényeket újból $w^{1118} \mathrm{vad}$ genotípusú hímekkel pároztattuk. Az utódnemzedék kifejlett egyedeit felboncolva 10,3\%-os gyakorisággal tapasztaltunk ivarsejthiányos fenotípust. A kísérlet negatív kontrolljaként további hat, embrionális ivarsejtekben nem expresszálódó gén alléljait vizsgáltuk a SOT érzékenyített háttéren (CG13744, AlCR2, CG14681, RPL8, Ance-3, $\operatorname{RrP} 4$ ). Ezen gének alléljai 0-9,8\% gyakorisággal okoztak ivarsejthiányos fenotípust SOT háttéren. Kísérletünkben az RNSi screen 48 jelöltjéből 45 gén 87 alléljának analízisét végeztük el. Ezek közül 32 gén 43 allélja mutatott a $w^{1118}$ kontrollnál több mint kétszer magasabb penetranciájú (>20,7\%) ivarsejthiányos fenotípust SOT háttéren. A kísérlet keresztezési sémáját a 20. ábra mutatja be, eredményeinket a 21. ábra grafikonján és a 3. táblázatban foglalom össze.

Mivel a felboncolt $F_{2}$ nőstényeknek elméletileg csak a fele hordozta a vizsgálandó mutáns allélt, ezért azokban az esetekben, mikor az ivarsejthiányos gonádok penetranciája 50\%-nál magasabb, feltételezhető, hogy az adott gén anyai hatású módon vagy anyai hatású módon is szerepet játszik az ivarsejtek fejlődésében. 


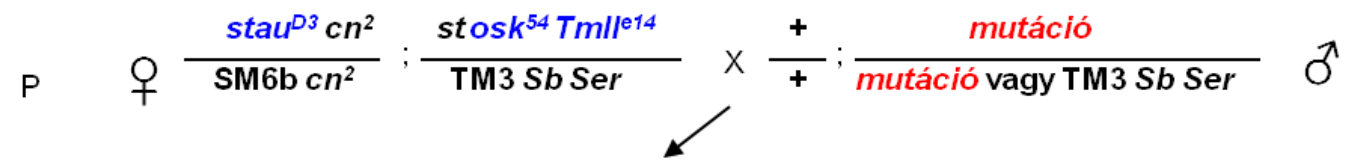

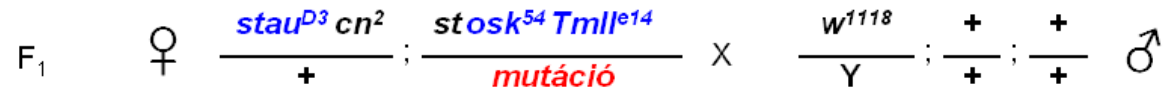

$$
\begin{aligned}
& \mathrm{F}_{2} \quad \text { Nöstény utódok boncolása, ivarsejt-hiányos fenotípus } \\
& \text { vizsgálata }
\end{aligned}
$$

20. ábra: A jelölt gének alléljainak vizsgálata SOT érzékenyített genetikai háttéren. A vizsgálandó allélt (piros) és az érzékenyítő allélokat (kék) hordozó nőstények nőstény utódaiban vizsgáltuk, hogy az ivarszervek tartalmaznak-e ivarsejteket.

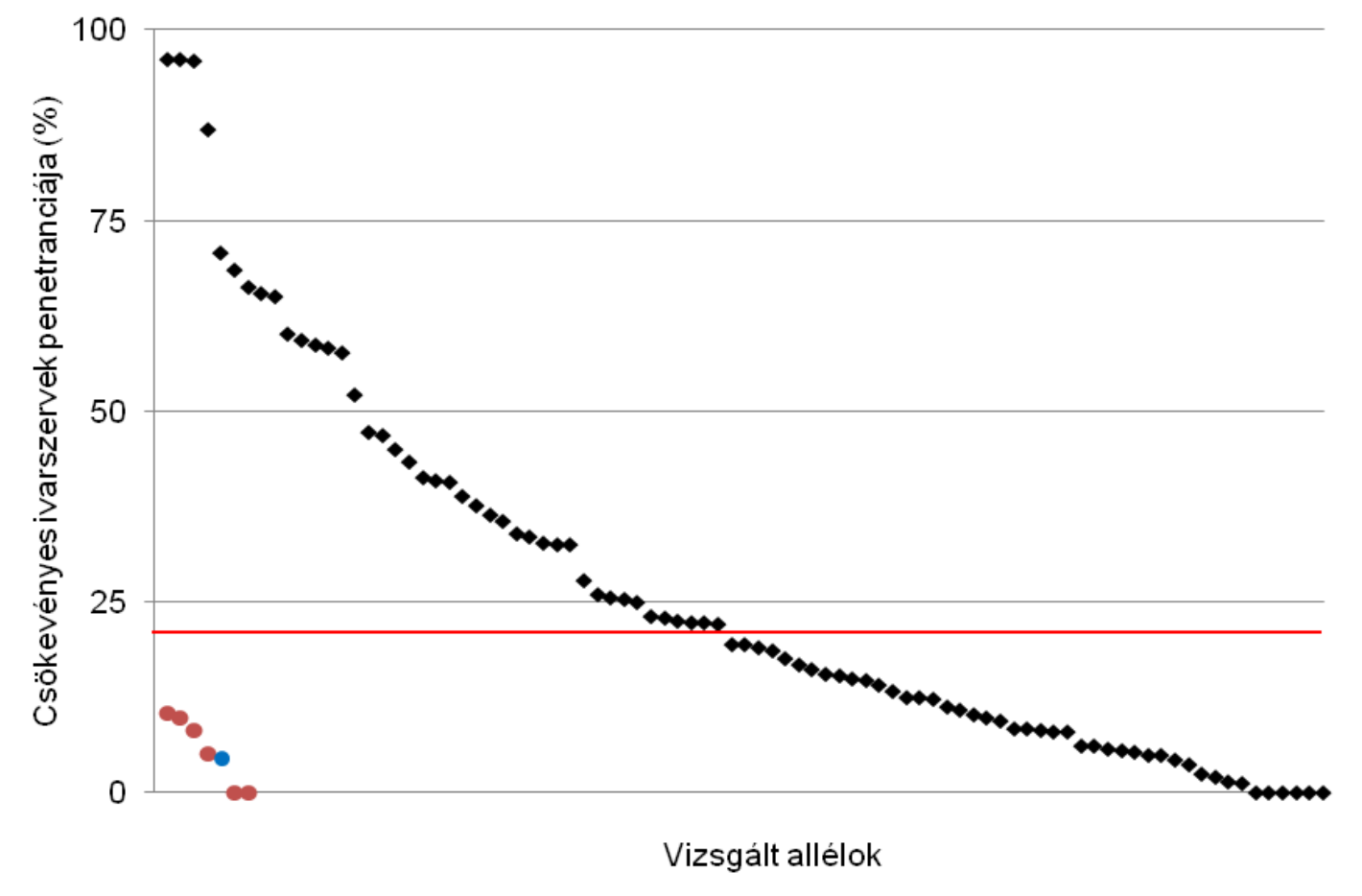

21. ábra: A vizsgált allélok ivarsejthiányos fenotípus-penetranciájának eloszlása SOT érzékenyített genetikai háttéren. Fekete négyzet: A vizsgált allélok ivarsejthiányos fenotípusának penetranciája. Az RNS interferencián alapuló géncsendesítési kísérletsorozat alapján kijelölt gének alléljainak csaknem fele mutatott a kontrolnál kétszer erősebb (20,7\%, piros egyenes) penetranciával ivarsejthiányos fenotípust . A kísérlet kontrolljaiként használt, az ivarsejtekben nem expresszálódó, de a Drosophila embrióban kifejeződő gének funkcióvesztéses alléljai a határérték alatt maradtak (piros pontok). A $w^{1118} ; s t a u^{D 3}, \mathrm{cn}^{2} / \mathrm{SM} 6 b, \mathrm{cn}^{2} ; s t^{l}, o s k^{54}, \mathrm{TmII}^{\mathrm{ll} /} / \mathrm{Tm} 3 \mathrm{Sb}^{l}, \mathrm{Ser}^{l}$ genotípusú érzékenyített háttér ivarsejthiányos fenotípusának penetranciája 10,34\% volt (kék pont). 
14 gén allélja adott SOT háttéren 50\%-nál magasabb fenotípust (3. táblázat). Ezen gének mindegyikére igaz, hogy mRNS-ük a korai (1-3 stádiumú) embriókban általánosan jelen van, és a 4-6 stádiumtól kezdődően válik ivarsejt-specifikussá (Malic enzyme (Men), CG8116, Regulator of eph expression (Reph), CG14545, caspar (casp), croquemort (crq), bel, scraps (scra)), vagy már a korai embriókban is ivarplazma lokalizációt mutat ( $p b l$, ool8 RNA-binding protein (orb), CycB, mbc, nos, spir) (Függelék 4. táblázat). Azoktól a génektől, melyek zigotikus módon járulnak hozzá az ivarsejt-fejlődéshez, nem várjuk, hogy a felboncolt (F2) állatokban az ivarsejthiányos gonádok gyakorisága 50\% felett legyen, hiszen F2 állatok fele nem hordozza a mutáns allélt.

Összefoglalva, a mutáns allélok SOT háttéren történt vizsgálatával az RNSi kísérletsorozat jelöltjei közül 32-ről bizonyítottuk, hogy az ivarsejt-fejlődésben részt vesz. Ezek közül 14 génről feltételezzük, hogy anyai hatású módon járulnak hozzá az ivarvonal fejlődéséhez. 


\begin{tabular}{|c|c|c|c|}
\hline Gén & Allél & $\begin{array}{l}\text { Ivarsejthiányos } \\
\text { gonád (\%) }\end{array}$ & $n$ \\
\hline spir & spir $^{83}$ & 96.15 & 26 \\
\hline scra & scra ${ }^{03421}$ & 96.00 & 25 \\
\hline orb & $o r b^{\text {CB-09ug-3 }}$ & 95.95 & 37 \\
\hline nos & $n o s^{L /}$ & 86.96 & 23 \\
\hline bel & $b e l^{\text {neo30 }}$ & 70.69 & 29 \\
\hline$m b c$ & $m b c^{E Y 0143 /}$ & 68.57 & 35 \\
\hline casp & $\operatorname{casp}^{c 04221}$ & 66.13 & 31 \\
\hline СусВ & $C y c B^{2}$ & 65.38 & 26 \\
\hline orb & $o r b^{d e c}$ & 65.00 & 30 \\
\hline CG14545 & CG14545 & 60.00 & 40 \\
\hline Reph & $\operatorname{Reph}^{\mathrm{CB}-\mathrm{b} / 1 /-3}$ & 59.26 & 27 \\
\hline CG8116 & CG8116 KGi00606 & 58.70 & 46 \\
\hline Men & $\operatorname{Men}^{n N C 1}$ & 58.33 & 30 \\
\hline pbl & $p b P$ & 57.69 & 26 \\
\hline crq & $\mathrm{crq}^{\operatorname{Y1} 14489}$ & 52.17 & 23 \\
\hline scra & scra $^{C 01769}$ & 47.22 & 36 \\
\hline mael & $\left.m a e\right|^{\mid Y u s s s 4}$ & 46.88 & 32 \\
\hline knrl & knrlMBusu/6 & 45.00 & 30 \\
\hline$p b l$ & $p b i^{3}$ & 43.24 & 37 \\
\hline casp & casp $p^{e 0000 y}$ & 41.18 & 34 \\
\hline CG14838 & CG14838 & 40.91 & 44 \\
\hline CycA & $C y c A^{H 1 / 0}$ & 40.70 & 43 \\
\hline feo & $f e o^{E A 86}$ & 38.78 & 49 \\
\hline$d s x$ & $d s x^{a 09623}$ & 37.50 & 40 \\
\hline Aos1 & Aos $1^{\text {c06048 }}$ & 36.36 & 33 \\
\hline spir & spir $^{7}$ & 35.53 & 38 \\
\hline CG7271 & CG7271 & 33.87 & 31 \\
\hline ade2 & ade $2^{N P 2741}$ & 33.58 & 67 \\
\hline$z p g$ & $z p g^{2-5332}$ & 32.69 & 26 \\
\hline KIp61F & Klp61F & 32.50 & 40 \\
\hline CG14438 & CG14438 & 32.43 & 37 \\
\hline$n c l b$ & CG6751 1 KGiU366s & 27.78 & 45 \\
\hline$p g c$ & 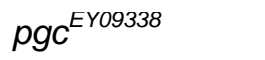 & 25.86 & 29 \\
\hline$m b c$ & $m b c^{D 11.2}$ & 25.53 & 47 \\
\hline CG13298 & CG13298 & 25.41 & 61 \\
\hline mael & maer ${ }^{r 20}$ & 25.00 & 38 \\
\hline Su(var)205 & Su(var)205 5 & 22.97 & 37 \\
\hline$m b c$ & $m b c^{c 0416 /}$ & 22.92 & 24 \\
\hline$c r q$ & $\operatorname{crq}{ }^{\mathrm{c} 01936}$ & 22.37 & 38 \\
\hline nos & $n o s^{U Y 4 / 41}$ & 22.34 & 47 \\
\hline$z p g$ & $z p g^{z-2533}$ & 22.22 & 54 \\
\hline
\end{tabular}

3. táblázat: SOT háttéren a kontrollnál kétszer erősebb ivarsejthiányos fenotípust mutató allélok. Felboncolt állatok száma: $\mathrm{n}$ 


\subsection{A jelölt gének evolúciós viszonyainak bemutatása és a génfunkciók jellemzése}

Kísérleteink az ecetmuslica ivarsejt-fejlődésében szerepet játszó gének azonosítására fókuszáltak, kézenfekvő kérdés tehát, hogy e fejlődési folyamatban résztvevő gének ortológjai megtalálhatók-e az állatvilág más fajaiban is. Az RNSi kísérletsorozat által azonosított evolúciósan konzervált génekről feltételezhető, hogy más fajokban is szerepet játszanak az ivarvonal-fejlődésében.

Az RNSi screen 48 jelölt génjének evolúciós konzerváltságát a FlyBase és az Ensembl adatbázisok segítségével térképeztük fel. Az azonosított gének 39,6\%-ának, azaz 19 génnek ortológjai megtalálhatók az élesztőben (Saccharomyces cerevisiae), jelezvén hogy ezen gének széles körben elterjedtek az eukarióta szervezetekben és feltehetően alapvető sejtfunkciókért felelösek. 35 gén $(72,3 \%)$ ortológját azonosítottuk gerinces fajokban (Xenopus tropicalis: Nyugati karmosbéka; Danio rerio: Zebradánió; Mus musculus: Házi egér; Homo sapiens: ember). Bizonyos szempontból ezek a gének a legérdekesebbek, hiszen az ivarvonal-fejlődés konzervált elemei ezek között keresendők. Egy másik gerinctelen modellszervezet, a fonalféreg Caenorhabditis elegans genomjában 32 gén ortológja található. Érdekes, hogy mindössze két olyan gén van (hangover (hang), zpg), melyek megfelelöje a fonalféregben megtalálható, de gerincesekben nem. Azon kevésbé konzervált 11 gén közül melyeknek ortológiai nem találhatók meg sem C. elegansban sem a gerincesekben, 4 általánosan elterjedt az ízeltlábúak körében (8,3\%), 2 rovarspecifikus (4,2\%), 5 génnek az ortológjai pedig csak Drosophila fajokban mutathatóak ki (10,4\%). A 48 gén között egy olyan sincs, amely kizárólag a Drosophila melanogaster fajra lenne jellemző (4. táblázat). 
A biológiai adatbázisok szerint, az általunk vizsgált 48 génből nyolcnak (16,7\%) (Bsg25D, casp, CG14545, CG17658, CG4281, CG8116,pgc, Reph) ezidáig egyáltalán nem ismert, és szekvencia hasonlóság alapján nem is jósolható molekuláris funkciója. További három génnek (CG14438, CG14838, CG7271) fehérjeszekvencia alapján molekuláris funkciója megjósolható, azonban nem ismert, hogy ezek milyen biológiai folyamatokban vesznek részt (4. táblázat). A Medline adatbázis segítségével feltérképeztük azokat a géneket, illetve ortológokat melyeknek az ivarsejt- vagy ivarszerv-fejlődésben betöltött szerepét korábban már feltárták (5. táblázat). Az RNSi screen 48 jelölt génje közül 18-nak mutatták ki valamilyen szerepét a Drosophila ivarvonal-fejlődésében (39,6\%). E 18 gén közül 13-nak más modellszervezetekben (C. elegans, karmosbéka, zebradánió, egér) vagy emberben bizonyított funkciója van az ivarsejt-fejlődésben. A jelölt gének nagyfokú konzerváltsága (37/48=77.1\%), és az a tény, hogy a konzervált gének jelentős részének $(13 / 37=35,1 \%)$ kimutatták az ivarvonal-fejlődésben betöltött szerepét más fajokban, arra enged következtetni, hogy az ivarvonal-fejlődése evolúciósan nagymértékben konzervált folyamat. Az ivarvonalfejlődésében szerepet játszó gének azonosítása érdekében kifejlesztett RNSi kísérletsorozatunk egyik legjelentősebb eredményének azt tartjuk, hogy 29 olyan új gént azonosítottunk, amelyeknek, ivarsejtekben betöltött szerepét idáig még nem írták le. A 29 új génnek háromnegyede (22) általánosan konzervált, kisebb hányada pedig Drosophila- (4), rovar- (2), vagy ízeltlábú-specifikus (1).

4. táblázat (64. o): RNSi screen jelölt génjenek molekuláris funkciója és evolúciós konzerváltsága. A molekuláris funkciókat összefoglaló táblázat a FlyBase adatbázis alapján készült, feltüntetve a kísérleti adatokból és a szekvenciahasonlóságokból származó eredményeket. Az evolúciós konzerváltságot a következő fajokban, taxonómiai csoportokban vizsgáltuka FlyBase és Ensembl adatbázisok alapján: Élesztő (Saccharomyces cerevisiae, Scer), Gyümölcslegyek családja (Drosophilidae); Rovarok osztálya (Insecta), Ízeltlábúak törzse (Arthropoda); C. elegans ; Nyugati karmosbéka (X. tropicalis); Zebradánió (D. rerio); Házi egér (M. musculus); ember (H. sapiens). Rövidítések: n.a.: nincs adat/nem ismert; PiP: foszfoinozitol-foszfát; cAMP:ciklikus adenozin monofoszfát; TF: transzkripciós faktor. +: ortológ kimutatható; -:ortológ nem mutatható ki, vagy nincs adat. 


\begin{tabular}{|c|c|c|c|c|c|c|c|c|c|c|}
\hline ade2 & Foszforibozil-formilglicinamidin szintáz & + & + & + & + & + & + & + & + & + \\
\hline Aos1 & SUMO-aktiváló enzim & + & + & + & + & + & + & + & + & + \\
\hline bel & ATP-függő RNS helikáz & + & + & + & + & + & + & + & + & + \\
\hline casp & n.a. & + & + & + & + & + & + & + & + & + \\
\hline CG13298 & mRNS-kötő & - & + & + & + & + & + & + & + & + \\
\hline CG8116 & n.a. & - & + & + & + & + & + & + & + & + \\
\hline CycA & Ciklin-függő szerin/treonin kináz regulátor & + & + & + & + & + & + & + & + & + \\
\hline СусВ & Ciklin-függő szerin/treonin kináz regulátor & + & + & + & + & + & + & + & + & + \\
\hline$d n c$ & 3', 5’ cAMP foszfodiészteráz & - & + & + & + & + & + & + & + & + \\
\hline elF5 & Transzlációs iníciációs faktor & + & + & + & + & + & + & + & + & + \\
\hline KIp10A & Mikrotubulus motor & + & + & + & + & + & + & + & + & + \\
\hline Klp61F & Mikrotubulus motor & + & + & + & + & + & + & + & + & + \\
\hline$m b c$ & Rac guanil nukleotid kicserélő faktor & + & + & + & + & + & + & + & + & + \\
\hline Men & Malát dehidrogenáz & + & + & + & + & + & + & + & + & + \\
\hline$n c l b$ & Kromatin DNS-kötő & + & + & + & + & + & + & + & + & + \\
\hline neur & $\begin{array}{l}\text { Ubikvitin-fehérje ligáz, DNS-kötő, PiP- } \\
\text { kötő }\end{array}$ & - & + & + & + & + & + & + & + & + \\
\hline nos & RNS-kötő & - & + & + & + & + & + & + & + & + \\
\hline orb & mRNS-kötő, fehérje kötő, Zn-ion kötő & - & + & + & + & + & + & + & + & + \\
\hline ovo & szekvencia-specifikus TF & - & + & + & + & + & + & + & + & + \\
\hline porin & feszültség-függő anion csatorna & + & + & + & + & + & + & + & + & + \\
\hline scra & Aktin-kötő, miktotubulus kötő & - & + & + & + & + & + & + & + & + \\
\hline Su(var)2-10 & RNS-helikáz, DNS-kötő , SUMO-ligáz & + & + & + & + & + & + & + & + & + \\
\hline Thiolase & Acetil-CoA aciltranszferáz & + & + & + & + & + & + & + & + & + \\
\hline$d s x$ & szekvencia-specifikus TF & - & + & + & + & + & + & + & + & + \\
\hline$B s g 25 D$ & n.a. & - & + & + & + & - & + & + & + & + \\
\hline CG14838 & ATPáz & - & + & + & + & - & + & + & + & + \\
\hline Phf7 & Hiszton-kötő, Zn-ion-kötő & - & + & + & + & - & + & + & + & + \\
\hline crq & scavenger receptor & - & + & + & + & + & + & + & + & + \\
\hline feo & Mikrotubulus-kötő & + & + & + & + & + & + & + & + & + \\
\hline pbl & Rac/Rho guanil nukleotid kicserélő faktor & - & + & + & + & + & + & + & + & + \\
\hline Su(var)205 & Hiszton-kötő, mRNS-kötő & - & + & + & + & + & + & + & + & + \\
\hline Pglym78 & Foszfoglicerát mutáz & + & + & + & + & - & + & + & + & + \\
\hline spir & Aktin-kötő, miktotubulus kötő & - & + & + & + & - & + & + & + & + \\
\hline Fs(2)Ket & Transzmembrán transzporter & + & + & + & + & + & - & - & + & + \\
\hline mei-P26 & Zn-ion kötő & - & + & + & + & + & + & - & - & - \\
\hline Tre1 & G-fehérje kapcsolt receptor & - & + & + & + & - & - & - & - & - \\
\hline hang & Zn-ion kötő & + & + & - & - & + & - & - & - & - \\
\hline$z p g$ & Gap junction csatorna & - & + & - & - & + & - & - & - & - \\
\hline CG4281 & n.a. & - & + & + & + & - & - & - & - & - \\
\hline knrl & szekvencia-specifikus TF & - & + & + & + & - & - & - & - & - \\
\hline mael & szekvencia-specifikus DNS-kötő & - & + & + & + & - & - & - & - & - \\
\hline CG14438 & fémion-kötő & - & + & + & - & - & - & - & - & - \\
\hline Reph & n.a. & - & + & + & - & - & - & - & - & - \\
\hline CG14545 & n.a. & - & + & - & - & - & - & - & - & - \\
\hline CG17658 & n.a. & - & + & - & - & - & - & - & - & - \\
\hline CG7271 & fémion-kötő & - & + & - & - & - & - & - & - & - \\
\hline$p g c$ & n.a. & - & + & - & - & - & - & - & - & - \\
\hline SuUR & DNS-kötő, ATP-kötő & - & + & - & - & - & - & - & - & - \\
\hline
\end{tabular}




\begin{tabular}{|c|c|c|c|}
\hline Gén & $\begin{array}{c}\text { Ismert funkció a Drosophila } \\
\text { ivarsejt-fejlödésben }\end{array}$ & Ortológok & $\begin{array}{c}\text { Ortológok ismert } \\
\text { funkciója } \\
\text { az ivarsejt-fejlödésben }\end{array}$ \\
\hline СусA & $\begin{array}{l}\text { Csíravonal őssejt fenntartás } \\
\text { Cisztasejt sejtciklus [83] }\end{array}$ & $\begin{array}{l}\text { Ccna1; } \\
\text { Ccna2(Mmus) }\end{array}$ & $\begin{array}{l}\text { Hím meiózis }[84,85] \\
\text { Nőstény meiózis }[86]\end{array}$ \\
\hline CycB & $\begin{array}{l}\text { Embrionális ivarsejt és csíravonal } \\
\text { őssejt osztódás [87] }\end{array}$ & $\begin{array}{l}\text { cyb-1 (Cele) } \\
\text { ccnb1 (Drer) } \\
\text { Ccnb1 (Mmus) }\end{array}$ & $\begin{array}{l}\text { Meiózis [88] } \\
\text { Petesejt érés [89] } \\
\text { Meiozis [90] }\end{array}$ \\
\hline$d s x$ & Szex determináció [91] & dmrt gének & Szex determináció [92] \\
\hline nos & $\begin{array}{l}\text { Ivarvonal kialakulás [93] } \\
\text { Csíravonal őssejt fenntartás [94] } \\
\text { Csíravonal őssejt } \\
\text { differenciálódás [95] }\end{array}$ & nanos gének & Ivarsejt-fejlődés [96-99] \\
\hline ovo & $\begin{array}{l}\text { Ivarvonal szex determináció [100] } \\
\text { Nőstény ivarvonal-fejlődés [101] }\end{array}$ & $\begin{array}{l}\text { Ovol1; Ovol2 } \\
\text { (Mmus) }\end{array}$ & $\begin{array}{l}\text { Spermatogenezis } \\
{[102,103]}\end{array}$ \\
\hline$p b l$ & Hím meiózis [104] & Ect2 (Mmus) & Nőstény meiózis [105] \\
\hline Su(var)205 & $4 x_{1} x_{1}$ & $\begin{array}{l}\text { Cbx1; Cbx3 } \\
\text { (Mmus) }\end{array}$ & $\begin{array}{l}\text { Spermatogenezis [106] } \\
\text { Embrionális ivarsejt- } \\
\text { ciklus [107] }\end{array}$ \\
\hline orb & $\begin{array}{l}\text { osk mRNA lokalizációja és } \\
\text { transzkripciója [108,109] } \\
\text { Spermatogenezis [110] }\end{array}$ & CPEB (Xtro) & Petesejt érés [111,112] \\
\hline Phf7 & Szex determináció [75] & $\begin{array}{l}\text { NYD-SP6/Phf7 } \\
\text { (Mmus) }\end{array}$ & Spermatogenezis [113] \\
\hline bel & Ivarvonal életképesség [114] & $D D X Y$ (Hsap) & $\begin{array}{l}\text { Spermatogenezis }[115,11 \\
6]\end{array}$ \\
\hline spir & $\begin{array}{l}\text { Osk lokalizáció a petesejtben } \\
\text { [117] }\end{array}$ & $\begin{array}{l}\text { Spire1, Spire2 } \\
\text { (Mmus) }\end{array}$ & Meiózis [118] \\
\hline$z p g$ & Ivarsejt-differenciálódás $[119,120]$ & inx-13 (Cele) & Petesejt érés [121] \\
\hline scra & Spermatocita-fejlődés $[122,123]$ & $\begin{array}{l}\text { ani-1, ani-2 } \\
\text { (Cele) }\end{array}$ & $\begin{array}{l}\text { Petesejt érés, meiózis } \\
{[124]}\end{array}$ \\
\hline$p g c$ & $\begin{array}{l}\text { Embrionális ivarsejt-fejlődés } \\
{[71,125]}\end{array}$ & (12 & (2) \\
\hline neur & Csíravonal őssejt fenntartás [126] & - & - \\
\hline$n c / b$ & Csíravonal őssejt fenntartás [74] & - & - \\
\hline mei-P26 & $\begin{array}{l}\text { Ivarsejt-differenciálódás [127- } \\
130]\end{array}$ & - & - \\
\hline mael & $\begin{array}{l}\text { Petesejt fejlődés [131,132] } \\
\text { Csíravonal őssejt } \\
\text { differenciálódás [133] }\end{array}$ & - & - \\
\hline Tre1 & Ivarsejt-vándorlás [14,17] & - & - \\
\hline
\end{tabular}

5. táblázat: Az RNSi screen jelölt génjeinek és ortológjainak ismert szerepe az ivarsejtfejlödésben. Caenorhabditis elegans (Cele); Nyugati karmosbéka (Xenopus tropicalis; Xtro); Zebradánió (Danio rerio, Drer); Házi egér (Mus musculus; Mmus); ember (Homo sapiens, Hsap). 


\subsection{Az RNSi kísérletsorozatban azonosított gének szövet- specificitásának vizsgálata.}

Az RNSi kísérletsorozatot dsRNS injektálással valósítottuk meg. Az injektálásos módszer mind a testi sejtekben, mind az ivarsejtekben csendesítheti a célgéneket. Kísérleteinkkel egyidőben elérhetővé vált az ún. mesterséges microRNSeken alapuló géncsendesítési technika, amelyben génspecifikus, short hairpin RNSeket (shRNS-eket) a GAL4-UAS rendszeren keresztül szövetspecifikusan lehet kifejeztetni [70]. Ivarsejt-specifikus GAL4-forrás alkalmazásával elérhető, hogy a géncsendesítő shRNS-ek csakis az ivarvonal sejtjeiben expresszálódjanak. Emiatt az esszenciális gének pleiotróp hatásából származó letalitás kiküszöbölhető, továbbá pontosabban meghatározható, hogy géncsendesítés az ivarvonal-fejlődés mely szakaszában, vagy szakaszaiban idéz elő rendellenességet. Mivel az embrionális ivarvonalsejtekben a zigotikus génkifejeződés sokáig represszált állapotú, nem vártuk el, hogy ivarvonal-specifikus géncsendesítéssel hatékonyan ismételni tudjuk a dsRNSek injektálásával kiváltott embrionális ivarsejt vagy ivarszerv fenotípusokat. A módszerrel kapcsolatos elvárásunk az volt, hogy a vizsgált génekről el tudjuk dönteni, hogy azok ivarsejt-specifikusan játszanak-e szerepet az ivarsejtek, illetve ivarszervek fejlődésében. Emellett az ivarvonal-specifikus géncsendesítési eljárást alkalmasnak véltük az RNSi kíserletsorozatban azonosított gének lárvális és adult ivarvonalban történő fenotípus vizsgálatára. Ezen elgondolások miatt az ivarvonalspecifikus géncsendesítést nem az dsRNS injektálást igazoló módszerként, hanem a dsRNS injektálással azonosított gének további jellemzésére kívántuk alkalmazni.

Habár jelenleg több mint 17.000 ivarvonalban kifejeztethető transzgenikus shRNS vonal érhető el (www.flyrnai.org), a dolgozat megírásáig nem publikáltak olyan 
nagyléptékü géncsendesítő kísérletsorozatot, amely az ivarvonal fejlődéséért felelős gének vizsgálatára irányult volna.

\subsubsection{Az ivarvonal-specifikus GAL4-források tesztelése}

Az ivarvonalban, UAS-GAL4 rendszeren keresztül történő géncsendesítéshez különböző ivarvonal-specifikus GAL4-források erősségét, valamint azok tér- és időbeli kifejeződési mintázatát teszteltünk kifejlett állatok ivarvonalában úgy, hogy ivarvonalban müködő GAL4-forrásokkal UASp-Actin-5C-GFP transzgént (UASp-ActGFP) fejeztettünk ki. Ezután a kiboncolt petefészkek GFP kifejeződés szintjét fluoreszcens sztereo-mikroszkópiával hasonlítottuk össze. Megállapítottuk, hogy a nos-GAL4-VP16, [134] és az osk-GAL4, [135] képes legerősebben expresszálni az UASp-Act:GFP transzgént (22.A és C ábra). A nos-GAL4 (P\{GAL4-nos.NGT\}40, [147] és bag of marbles-GAL4 (bam-GAL4) (P\{bam-GAL4:VP16\} [136] az előzőeknél kisebb mértékü transzgén-expressziót eredményez (22.B és D ábra). Részletesebb, konfokális mikroszkópiás vizsgálattal azt is kimutattuk, hogy a nosGAL4 és nos-GAL4-VP16 GAL4-források a kifejlett állatokban, mindkét nemben az ivarvonal minden sejtjében működnek (22.A', A" és B', B” ábra). Bár a nos-GALA driver a nos-GAL4-VP16-nál általánosságban gyengébb transzgén kifejeződést eredményez, de kifejlett állatok heréjének csíravonal őssejtjeiben kifejezetten erős az aktivitása. A nos-GAL4-VP16 kiméra fehérjét kódol, a GAL4 fehérjéhez virális eredetü fehérjeszekvenciát (VP16) kapcsoltak, ami erősebb GAL4 kifejeződést tesz lehetővé [137]. Az osk-GAL4 GAL4-forrás a herékben nem, de a petefészkekben a petefejlődés az első stádiumától kezdve (germárium 3. régiója) végig erősen biztosítja az UASp-Act:GFP transzgén expresszióját (22.C' és C" ábra). A bam-GAL4 GAL4forrás mindkét nemben az ivarvonal őssejt utódsejtjeiben (hímekben goniálblaszt, 
nőstényekben cisztoblaszt) erősen müködik, ezután lecsengő mintázatot mutat (22.D’ és D” ábra). Kísérleteinkben, a jelölt gének felnőttkori ivarsejt fenotípusainak leírásához a nos-GAL4-VP16 GAL4-forrást használtuk, mivel a vizsgált meghajtó elemek közül ez már a felnőtt ivarszervek ivarvonal őssejtjeiben is működik, és ezzel lehet az ivarvonalban legerősebb transzgén kifejeződést elérni.
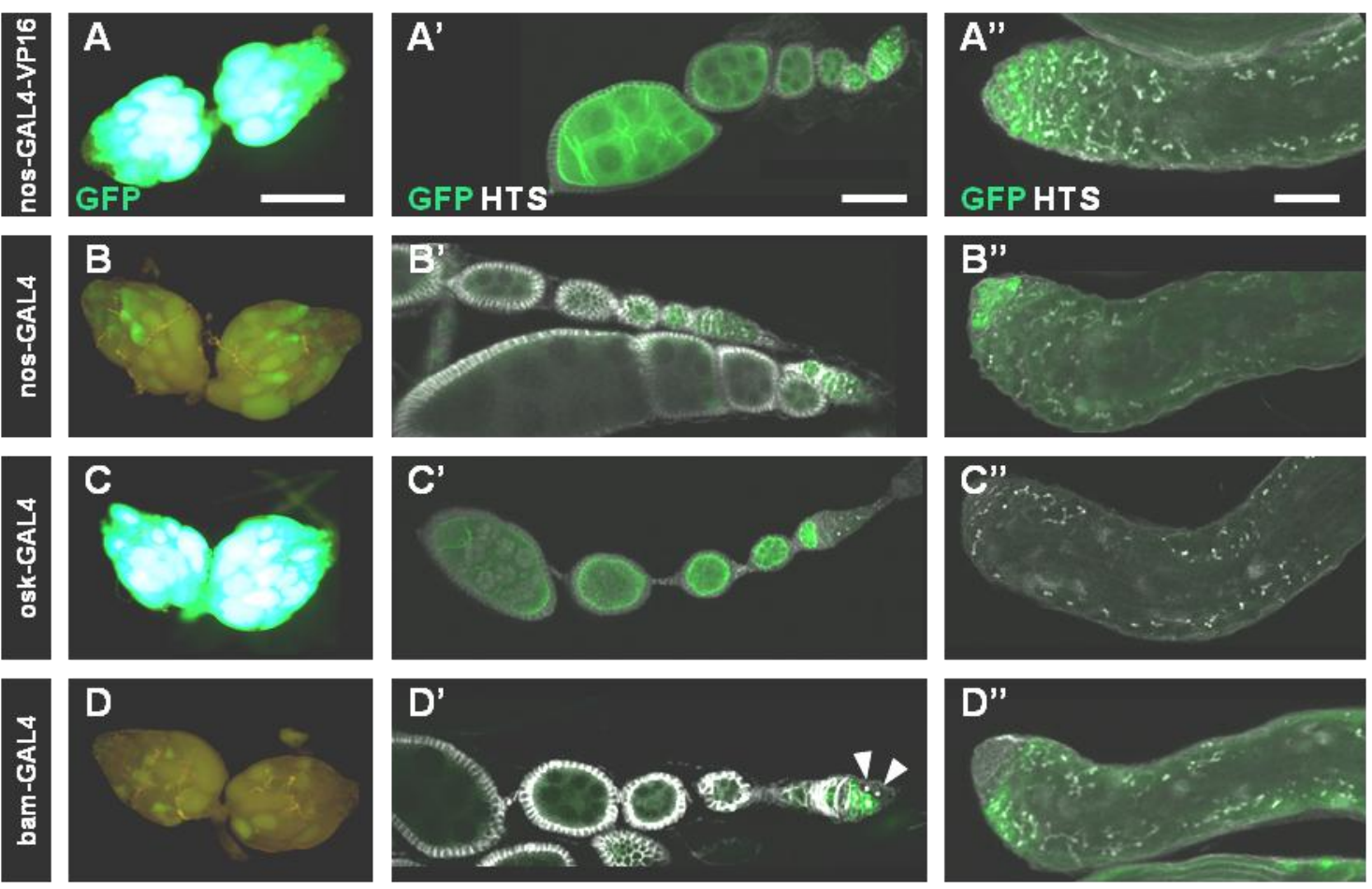

22. ábra: Ivarvonal-specifikus GAL4-források erőssége és kifejeződési mintázata. Részletes magyarázat a szövegben. A-D: A GAL-4 források kiefeződésének mértékét a kifejlett állatok petefészkén $U A S p$-GFP transzgén meghajtásával mértük. A GFP jelerősség arányos a GAL4-forrás kifejeződés mértékével. A felvételek azonos mikroszkóp- és képfeldolgozási beállitásokkal készültek. Mérték: $500 \mu \mathrm{m}$.

A'-D": A GAL4-források kifejeződésének mintázata kifejlett állatok petecsöveiben (A'-D') és heréiben (A"-D"). A térbeli kifejeződési mintázatokat szintén UASp-GFP transzgén kifejeztetésével határoztuk meg. Ebben az esetben a felvételek eltérő beállitásokkal készültek. GFP jel: anti-GFP (zöld),

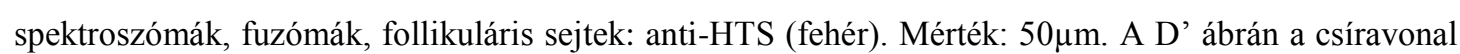
össejteket fehér nyílhegyek jelölik. 


\subsubsection{Az ivarvonal-specifikus géncsendesítés jellemzése}

Ni és munkatársai kimutatták, hogy miR-1 alapú shRNS transzgének érésében a miRNS útvonal enzimei vesznek részt, majd a keletkező kis RNS-ek a mikro-RNS útvonal effektor enzimeibe (AGO1) kötödnek [70]. Ismert, hogy a miRNS útvonal fontos szerepet játszik Drosophila ivarvonal-fejlődésben: a csíravonal őssejtek fenntartásában, a cisztobalsztok differenciálódásában és a peteérésben [138-140]. Ezért megvizsgáltuk, hogy a miRNS útvonalon keresztül történő géncsendesítés a miRNS útvonalban szerepet játszó enzimek kapacitásainak lekötése miatt nem okoz-e rendellenességet az ivarvonal fejlődése során. A nos-Moe.EGFP fúziós gént hordozó állatok ivarsejtjei az egyedfejlődés folyamán, mindkét nemben fluoreszcens jelet bocsátanak ki [141]. A moesin-GFP fúziós génre shRNS konstrukciót (UASp-eGFPshRNS) terveztünk, és azt ivarvonal-specifikus transzgén kifejeztetésre kifejlesztett VALIUM22 vektorba inszertáltuk (Függelék 1. ábra), majd transzgenikus Drosophila vonalakat hoztunk létre. A nos-GAL4-VP16 jelü ivarvonalban kifejeződő GAL4forrással kifejeztettük a GFP fúziós gén elleni shRNS-t és megvizsgáltuk, hogy ennek, az ivarvonal-fejlődés szempontjából indifferens transzgénnek csendesítése okoz-e aspecifikus mutáns fenotípust az ivarvonalban. A transzgenikus UASp-eGFP-shRNS Drosophila vonal elöállítása után nemzetközi törzsközpontból is elérhetővé vált GFP elleni shRNS, igaz szomatikus transzgén kifejeztetésre kifejlesztett VALIUM20-as vektorban (Függelék 1. ábra). A nos-GAL4-VP16 ivarvonal driver segítségével ez utóbbi UAS-eGFP-shRNS-sel is elvégeztük a nanos promóterrel meghajtott GFPfúziós gén csendesítését, kontrollként shRNS-t nem hordozó állatokat vizsgáltunk. Mindkét UAS-eGFP-shRNS transzgén ivarvonal-specifikus kifejeztetése esetén azt figyeltük meg, hogy a kifejlett állatok petefészkeiben és heréiben a fluoreszcens jel nagymértékben lecsökkent. A petefejlödés kései stádiumaiban a GFP kifejeződés 
ismét kimutatható volt, azonban ez nem érte el azt a szintet, amelyet a csendesítés nélkül figyelhetünk meg (23. ábra). Ez utóbbi megfigyelés arra enged következtetni, hogy a nos-GAL4-VP16 GAL4-forrással indukált, ivarvonal-specifikus géncsendesítés hatékonysága a petefejlődés során csökken.

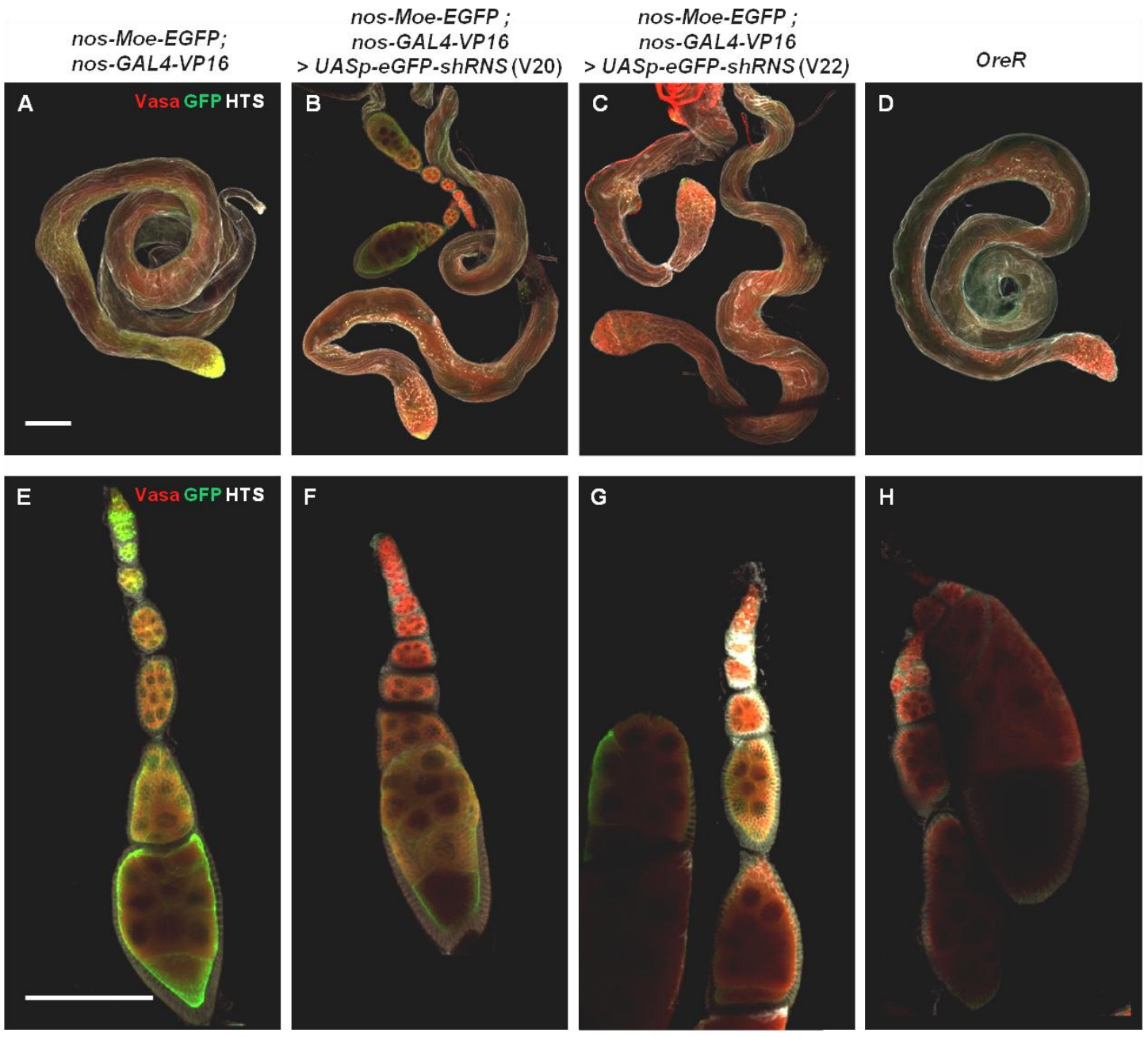

23. ábra: GFP-fúziós transzgén csendesítése GFP-t kifejező ivarvonalban. A zöld mintázat a fluoreszcens fúziós fehérje szintjével arányos (anti-GFP), míg a pirossal az ivarsejtek festődnek (antiVasa), a fehér szín a follikuláris sejtek sejthártyáját és az ivarsejt-specifikus organellumokat: a spektroszómákat és a fuzómákat jelöli. Mérték: $100 \mu \mathrm{m}$. Az ivarvonal-specifikus driverrel (nos-GAL4VP16) meghajtott UASp-GFP-shRNS-ek jelentősen csökkentik a GFP fúziós fehérje szintjét kifejlett állatok heréiben (A-C), és petecsöveiben (E-G), míg azok felépítése a vad típushoz (OreR) hasonló marad. A felvételek azonos mikroszkóp-, és kamera- és képfeldolgozási beállításokkal készültek.

Genotípusonként 30-30 hímet, illetve nőstényt felboncolva és konfokális mikroszkóppal megvizsgálva sem találtunk rendellenességeket (23. ábra), a 
géncsendesítésen átesett állatok fertilisek voltak. Kísérletünk bizonyítja, hogy a miRNS útvonalon történő géncsendesítés nem okoz aspecifikus fenotípusokat az ivarvonalban. Kimutattuk továbbá azt is, hogy az eredetileg testi sejtekben történő transzgén kifejezésre kifejlesztett VALIUM20 vektorba épített shRNS-ek is hatékonyan képesek csendesíteni a célgént.
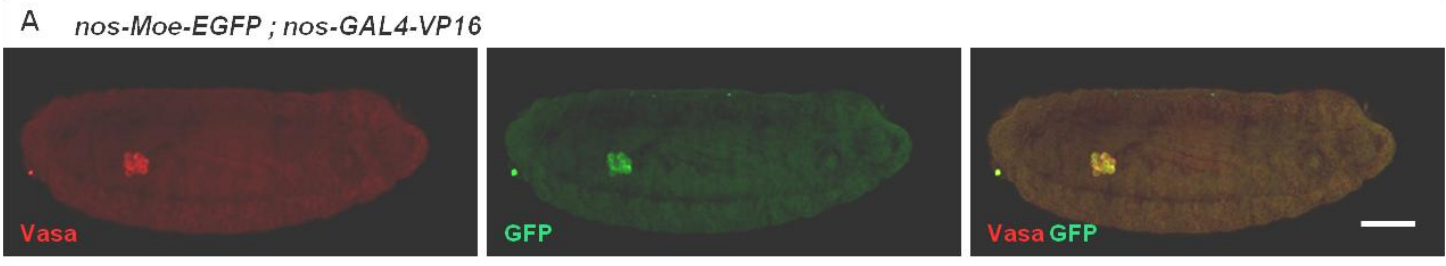

B nos-Moe-EGFP; nos-GAL4-VP16> UASp-eGFP-shRNS(V22)
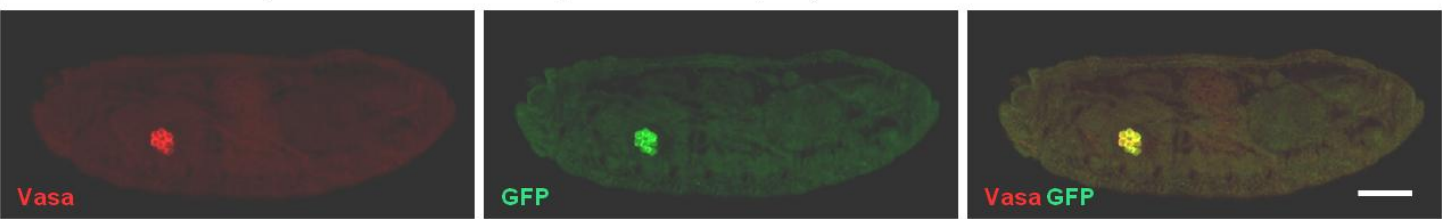

24. ábra Az ivarvonal-specifikus, shRNS alapú géncsendesítés az embriógenezis során nem működik. A 16. stádiumú embriókban az ivarsejtekben kifejeződő GFP fehérje szintje nem csökken jelentős mértékben az ivarsejt-specifikus nos-GAL4-VP16 driverrel kifejeztetett UASp-eGFP-shRNS hatására. Mérték: $50 \mu \mathrm{m}$.

Kísérleti elrendezésünkben a fluoreszcens jel kioltása egyben arról is információt ad, hogy a géncsendesítés a Drosophila egyedfejlődés melyik szakaszában fejti ki hatását. Az embrionális fejlődés végén (16-17. stádium) csendesítés hatására a fluoreszcens fehérje szintje nem csökkent, ami arra utal, hogy a zigotikus shRNS aktiválás ebben a fejlődési szakaszban az ivarvonalban még nem hatékony (24. ábra). Megjegyzendő, hogy a transzgenikus GFP fehérje igen stabil, lassan degradálódó fehérje [142], és nos promóter és 3'UTR szekvenciáknak köszönhetően anyai hatással már a korai embriók ivarvonalában is megjelenik. E módszerrel csendesítve a Tre1 gént a nos-GAL4-VP16 és Tre1-shRNS-t hordozó állatok nem mutatnak ivarsejthiányos fenotípust kifejlett állatokban, míg ugyanezen genotípusú nőstények utódaiban az ivarsejthiányos fenotípus magas előfordulási 
gyakorisággal mutatható ki (Függelék 5. táblázat, 4.5.3 fejezet). A Tre1 gén az embrionális ivarsejtek a középbél-kezdemény falán történő transzepiteliális vándorlásban vesz rész az embrionális fejlődés 9-10 stádiumában [14,17]. Az, hogy a zigotikusan kifejeztetett Trel-shRNS nem okoz rendellenességeket, míg az anyai hatású igen, arra utal, hogy korai embriókban (10. embrionális stádium előtt) a zigotikus géncsendesítés a miRNS útvonalon keresztül inaktív. A kísérlet azt is bizonyítja, hogy az anyai hatással örökített shRNS-ek hatékonyan degradálják a mRNS-eket a korai embriókban. Habár a miRNS útvonalon ivarvonal-specifikus géncsendesítés hatékonyságát a bemutatott módszerrel nem vizsgáltuk a lárvális ivarszervekben, úgy gondoljuk az a nos-GAL4-VP16 GAL4-forrással indukált ivarvonal-specifikus géncsendesítés a késői lárvák ivarvonalában aktív. Ezt bizonyítják a később bemutatott kísérletek is (4.6.1 és 4.6.3 és 4.6.4 fejezetek).

\subsubsection{Az ivarvonal-specifikus shRNS alapú géncsendesítés eredménye}

A géncsendesítéses kísérletsorozat 48 jelölt génjéböl 46 gén ellen, összesen 70 UAS-shRNS géncsendesítő transzgén volt elérhető a dolgozat megírásakor. A nosGAL4-VP16 GAL4-forrást és a célgén elleni UAS-shRNS-t egyaránt hordozó kettős heterozigóta állatokat hoztunk létre, majd a kifejlett állatok felboncolásával megállapítottuk a csökevényes ivarszervek elöfordulási gyakoriságát hímekben és nöstényekben is. Azon célgének esetén, melyek ellen több shRNS vonalat is beszereztünk, azt tapasztaltuk, hogy nem minden shRNS konstrukció müködött. Például a $C y c B$ gént hat különböző shRNS transzgénnel csendesítettük, de ezek közül csak három okozott csökevényes ivarszerv-fenotípust (Függelék 5. táblázat). Becsléseink szerint a shRNS-eknek harmada-fele egyáltalán nem fejt ki géncsendesítő hatást. A 46 jelölt gén ellen 70 elvégzett géncsendesítési kísérlet során 27 gén 
esetében figyeltünk meg csökevényes petefészkeket nagy gyakorisággal. A hímek esetében 18 gén ivarsejt-specifikus csendesítése eredményezett csökevényes heréket magas gyakorisággal. A felnőtt kori csökevényes petefészek és here fenotípus vad típusban elhanyagolható gyakorisággal fordul elő. Mindössze egy gén, a Ketel $(F s(2) K e t)$ csendesítése esetén figyeltük meg, hogy a petefészkek normálisan fejlödtek, de herék csökevényesek voltak. Habár a nőstény állatok által lerakott peték morfológiájukat tekintve vad típushoz hasonlónak látszottak, terméketlenek voltak.

Azokban az esetekben, mikor az ivarvonal-specifikus géncsendesítés csökevényes petefészkek kialakulását eredményezte kifejlett állatokban, részletesebb vizsgálat céljából a kiboncolt szerveken az ivarsejteket jelölő Vasa, a spektroszómákat, a fuzómákat és a follikuláris sejteket jelölő HTS ellenanyag- és DAPI-festést végeztünk. Az ivarszervek csökevényességét okozó fenotípusokat konfokális mikroszkópia segítségével vizsgáltuk meg részletesebben (25. ábra).

Néhány esetben ivarsejtek egyáltalán nem voltak azonosíthatók a petecsövekben (25.B ábra). A zpg, a CG4281 a pbl és a scra ivarvonal-specifikus csendesítése esetén ezt a teljes ivarsejthiányos fenotípust figyeltük meg. További kilenc gén (Su(var2-10), Aos1, bel, feo, Klp61F, eIF5, mei-P26, CG8116, CG13298) csendesítésénél pedig ivarsejthiányos és kevés petekezdeményt tartalmazó petecsövekböl álló mozaikos petefészkeket kaptunk. A CG13298, az Aos1 és a Su(var)2-10 gének csendesítésénél átmeneti fenotípust is megfigyeltünk: kis gyakorisággal kimutatható volt Vasa pozitív sejtek jelenléte a petecsövek csúcsi részén. (25.C ábra). Ezekben az ivarsejtekben azonban az őssejteket jellemző spektroszóma sokszor már nem volt megfigyelhető. A megítélésünk szerint a spektroszóma nélküli, Vasa pozitív sejtek pusztuló ivarsejteket jeleznek. 

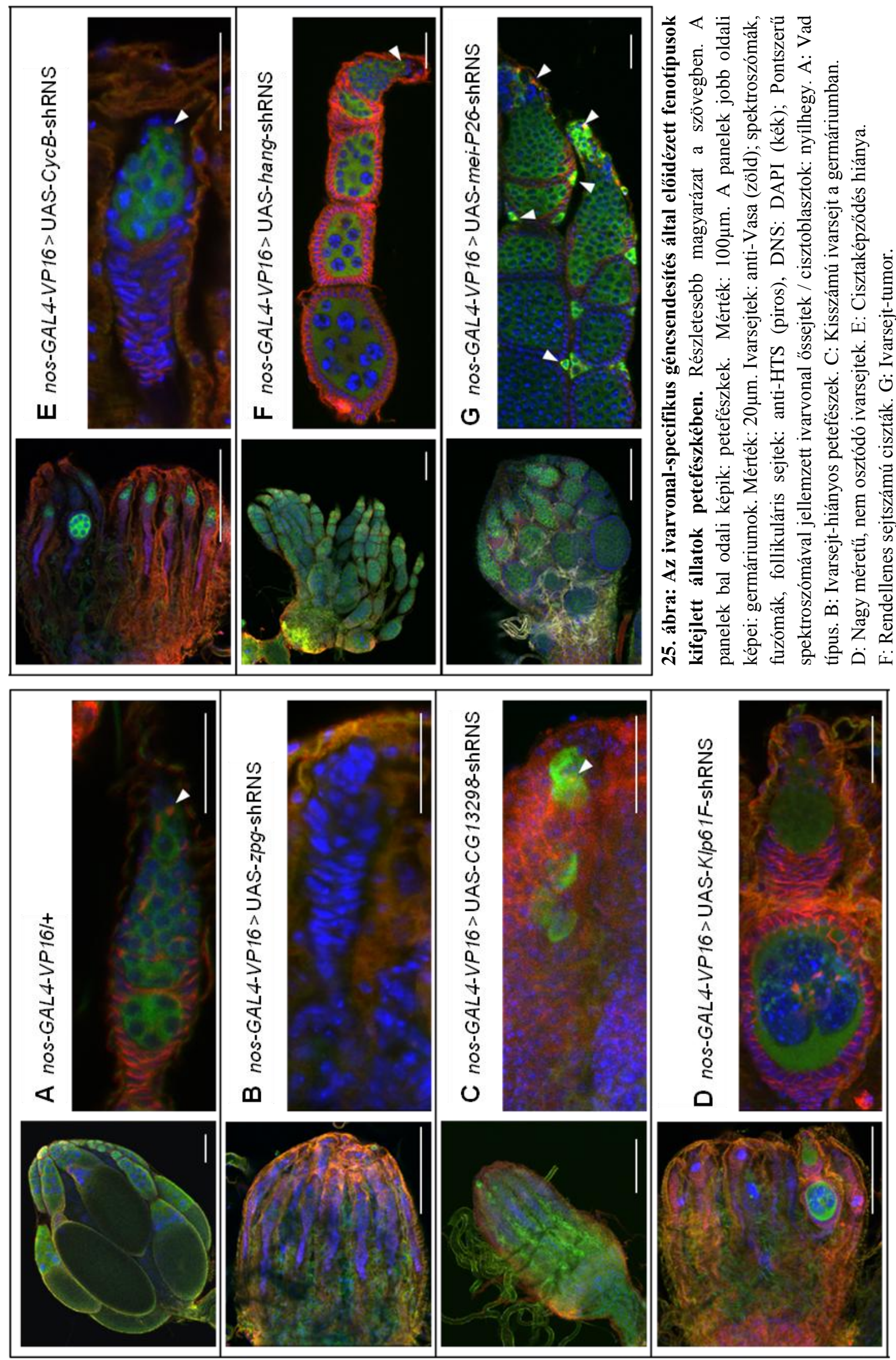
A feo, Klp61F, bel gének csendesítése abnormálisan nagyméretü ivarsejtek megjelenését eredményezte a kifejlett állatok petecsöveiben (25.D ábra). Az óriás méretű ivarsejtekben nagy mennyiségü DNS halmozódott fel, ami arra utal, hogy a gének csendesítése az ivarsejtek osztódásának hibáját okozták. Míg a feo és Klp61F esetében többsejtes cisztákat nem figyeltünk meg, addig a bel gén csendesítése után többsejtes, rendellenes számú sejtből álló cisztaszerü képződményeket találtunk. A cisztaszerü képződményekben a HTS ellenanyaggal jellemezhető fuzómákat nem tudtuk kimutatni. Mindhárom gén csendesítése során megfigyeltünk olyan petecsöveket, melyekben Vasa festődés már nem volt detektálható, de a nagymértékü DNS aggregáció (DAPI festődés) jelezte, hogy ezekben nagyméretű pusztuló sejtek voltak jelen.

A $C y c B$ - és $C G 8116$-shRNS ivarvonal-specifikus kifejeztetése során azt tapasztaltuk, hogy a petecsövek csúcsi részén a spektoszómával jellemezhető őssejtek és cisztoblasztok rendben megtalálhatók voltak, azonban 16 sejtes ciszták nem, vagy ritkán alakultak ki (25.E ábra). A $C y c B$ csendesítése esetén kis gyakorisággal figyeltünk meg cisztákat, ezek vad fenotípusúnak tüntek. A CG8116 csendesítése esetén is megfigyeltünk többsejtü cisztákat a petecsövekben, azonban ezek kivétel nélkül abnormális morfológiát és sejtszámot mutattak, ezekben érett pete nem fejlődött. Kísérleteink arra utalnak, hogy a $C y c B$ a cisztoblasztok osztódásához szükséges, géntermék hiányában a cisztoblasztokból többsejetes ciszták nem alakulnak ki. Ezzel szemben a CG8116 hiányában a cisztoblasztok, ugyan csökkent mértékben, de képesek lehetnek az osztódásra, azonban a cisztaképződés hibát szenved.

A CG8116, a hang, a nclb, a $S u(v a r) 205$ és a mael gének csendesítése során ciszták ugyan kialakultak, de bennük a petesejt differenciációja nem indult meg. A fenotípus gyakran együtt járt rendellenes cisztasejt-számmal. A hang és mael 
csendesítések esetében gyakran figyeltünk meg 16-nál több ivarsejtet tartalmazó cisztákat (25.F ábra), a CG8116-nél pedig gyakran fordultak elő 16 sejtnél kevesebbet tartalmazó ciszták. Mind a négy gén csendesítésénél előfordultak olyan ciszták, melyekben a sejtek eltérő méretűek, rendellenes morfológiájúak voltak.

A mei-P26 gén ivarvonal-specifikus csendesítése ivarsejt tumort okozott (25.G ábra). A fenotípus mei-P26 mutánsok vizsgálatából már ismert volt $[129,130,143]$. A szakirodalomban leírt fenotípushoz hasonlóan, a shRNS alapú csendesítéskor is ún. cisztatumorok azonosíthatóak a petecsövekben. A ciszta tumorok rendellenesen sok Vasa pozitív sejtet tartalmaznak, és bennük megfigyelhetők az elágazó fuzómák. Érdekes jelenség, melyről a korábbi fenotípus leírások nem számolnak be, hogy a petecsövek falán, a germáriumtól távol, a follikuláris sejtek rétegén kívül is láthatók vasa pozitív sejtek, melyek gömbszerü spektroszómát hordoznak.

Azokban az esetekben, melyekben a GAL4-forrást és az UAS-shRNS transzgént hordozó nőstények csökevényes ivarszerv-fenotípust nem, vagy csak ritkán mutattak, a kettős transzgenikus nőstényeket vad típusú hímmel kereszteztük és teszteltük fertilításukat (Függelék 5. táblázat). Amennyiben az ivarvonal-specifikus géncsendesítésen átesett nőstények fertilisnek bizonyultak, a keresztezésbők kikelő utódokat is felneveltük, és a kifejlett állatokat felboncoltuk. Négy gén $(\operatorname{Tre} 1, d s x$, nos, spir) csendesítése okozott az utódgenerációban csökevényes ivarszerveket úgy, hogy a fenotípus az szülői nemzedékben nem, vagy csak kis mértékben volt megfigyelhető. A jelenségnek két magyarázata van: egyrészt a kettős transzgenikus nőstények azért nem mutattak fenotípust, mert a csendesített gén csak az embrionális ivarvonalsejtek fejlődéséhez szükséges, amikor az ivarvonal-specifikus géncsendesítés még nem müködik. A másik magyarázat szerint a GAL4-forrást és az UAS-shRNS-t hordozó nőstényekben a fenotípus azért nem nyilvánult meg, mert bennük az anyai hatással örökölt, vagy a korai embrionális korban transzlálódott fehérjék menekítették a felnőtt 
kori fenotípust. Mindkét esetben az utódok anyai örökségként nem a célgén fehérjetermékét, hanem a peteérés során átíródott shRNS-t kapták, mely az utódnemzedékben csendesítette a célgént, ezért a kifejlett egyedekben csökevényes (ivarsejthiányos) ivarszervek fejlődtek.

Az injektált dsRNS-ek nem csak az ivarsejtekben, hanem a testi sejtekben is kifejtik hatásukat, ezért ezzel a módszerrel kapott ivarsejt-fenotípusok akár a testi sejtekben müködő géncsendesítés másodlagos hatásának következményei is lehetnek. A shRNS alapú, ivarvonal-specifikus géncsendesítés bizonyíthatja, hogy egy gén ivarsejt-függő módon járul hozzá az ivarsejtvonal fejlődéséhez. A dsRNS injektáláson alapuló RNSi kísérletsorozat 48 jelöltje közül 23 gén csendesítése okozott kifejlett állatokban csökevényes ivarszerv fenotípust. Ezek közül 20 génre volt elérhető ivarvonalban kifejeztethető shRNS transzgén. A húszból nyolc génről (Aos 1, Su(var)205, Su(var)2-10, hang, mei-P26, zpg, feo, bel) kimutattuk, hogy ivarsejtfüggő módon járulnak hozzá az ivarvonal-fejlődéséhez felnőtt nőstényekben. További három gén (nos, Tre1, spir) azt tapasztaltuk, hogy shRNS-üknek ivarvonalban történő kifejeztetése anyai hatású módon okozott ivarsejthiányos fenotípust. Ezen eredményeink egybevágnak azokkal az ismeretekkel, miszerint a nos, a spir, és a Tre1 hozzájárul az ivarsejtek kialakulásához, fenntartásához és fejlődéséhez az embriogenezis korai szakaszában [14,78,144,145]. A doublesex gén ivarvonalspecifikus csendesítése az előző három génhez hasonlóan a kettős transzgenikus állatok utódnemedékében okozott ivarsejthiányos fenotípust a nőstény állatokban (Függelék 5. táblázat). A $d s x$ gén testi sejt függő módon járul hozzá az embrionális ivarszervek nemének meghatározásához nőstényekben [146]. Ebben az esetben tehát arról van szó, hogy GAL4-forrást és az UAS-shRNS transzgént hordozó állatok petéinek citoplazmájában a $d s x$-shRNS átöröklődik, és az immár nem ivarvonal-függő módon is ki tudja fejteni hatását az utód $\left(\mathrm{F}_{2}\right)$ embriók szomatikus eredetű sejtjeiben. 


\subsection{Az RNSi kísérlesorozatban azonosított gének részletes genetikai jellemzése}

A géncsendesítő kísérletsorozatban azonosított gének közül azokat választottuk ki részletesebb genetikai jellemzés céljából, amelyek ivarsejt-fejlődésben betöltött szerepe nem, vagy csak részlegesen ismert. Olyan pleiotróp hatású géneket vizsgáltunk, melyeknek a testi sejtekben betöltött funkciója miatt az ivarvonalspecifikus hatásuk nem, vagy csak korlátozott mértékben vizsgálható klasszikus mutánsokkal. A géncsendesítésen alapuló módszerek segítségével azonban e géneknek az ivarvonal-specifikus funkciója jól jellemezhető. A jellemezni kívánt gének kiválasztásánál fontos szempont volt, hogy evolúciósan konzervált (gerincesekben ortológokkal rendelkező) géneket válasszunk, hiszen a Drosophilában kimutatott funkció hozzájárulhat például az ortológ gének emlős ivarsejt-fejlődésben betöltött szerepének megismeréséhez.

\subsubsection{A feo gén az ivarvonalsejtek osztódásához szükséges}

A fascetto (feo) X-kromoszómán elhelyezkedő gén, amely konzervált mikrotubulus kötő fehérjét kódol. A feo gén elleni dsRNS injektálása korai embriókban nem okozott rendellenességeket az embrionális ivarsejt-fejlődésben és ivarszerv-kialakulásban, azonban a feo-dsRNS-sel kezelt állatok kifejlett korukban 57,2\%-os gyakorisággal csökevényes ivarszerveket hordoztak (Függelék 3. táblázat). A dsRNS-sel injektált embriókból fejlődő első és harmadik stádiumú, vándorló lárvák ivarszerveit immunohisztokémiai módszerrel vizsgálva azt tapasztaltuk, hogy mind a lárvális herékben, mind a petefészkekben a vad típusnál kisebb számú, de nagyobb méretü Vasa pozitív sejt található (26.C-D ábra). 

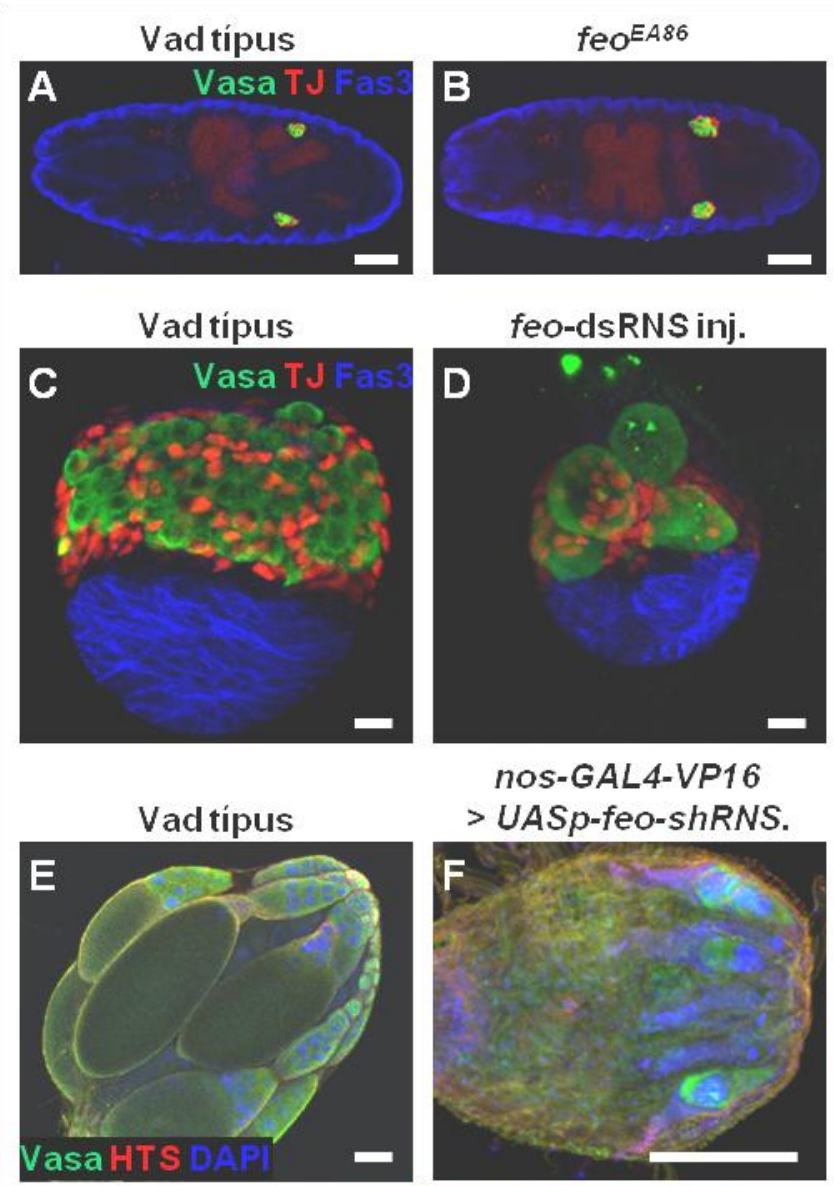

nos-GAL4-VP16 $>$ UASp-feo-shRNS.
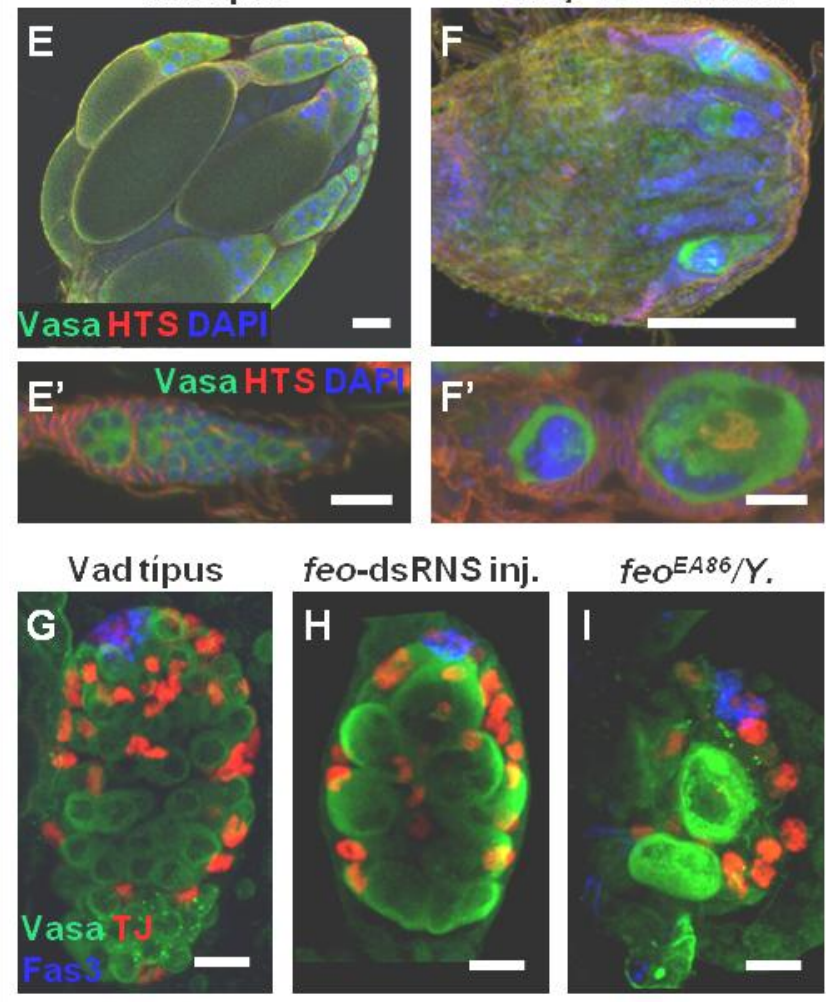

26. ábra: A feo funkcióvesztéses fenotípusai különbőző fejlődési stádiumokban. A-B: Késői embrionális korban a vad típushoz (A) hasonló számú és méretü ivarsejt található a $f e o^{E A 86}$ nullmutáns késői embriók ivarszervében (B). Ivarsejtek: antiVasa (zöld), Ivarszervek szomatikus sejtjei: anti-Tj (piros), embrionális hám: anti-FasIII (kék). Mérték: $50 \mu \mathrm{m}$.

C-D: Harmadik stádiumú lárvális stádiumban a feo-dsRNS-sel injektált állatok petefészkében (D) kevesebb, de nagyobb méretü ivarsejt (anti-Vasa: zöld) van, mint a vad típusú állatokéban (C). A szomatikus eredetü (anti-TJ: piros; anti-Fas3: kék) sejtek méretében és számában lényegi változás nincs. Mérték: $10 \mu \mathrm{m}$.

E-F: Vad típusú (E) és géncsendesített állat petefésze (F). A kifejlett nőstényekben, ahol a feo gént ivarsejt-specifikusan csendesítettük ( $F$ és $F^{\prime}$ ), a petefészekek csökevényesek voltak (F), érett peték nem keletkeztek. A petecsövekben kevés, nagyméretü Vasa pozitív sejt volt kimutatható, nagy mennyiségü, sokszor kondenzált DNS-sel (DAPI: kék), a spektroszómák fuzómák, (anti-HTS: piros) is rendellenes morfológiát mutattak (F'). Mérték: $100 \mu \mathrm{m}$; E', F': germárium mérték: $20 \mu \mathrm{m}$.

G-I: Első stádiumos lárvális herék. Vad típus (G), géncsendesített állat heréje (H), hemizigóta mutáns állat heréje (I). Az első stádiumú lárvális herékben géncsendesítés hatására $(\mathrm{H})$ szintén kevesebb számú és nagyobb méretű ivarsejt (anti-Vasa: zöld) fejlődőtt, mint a vad típusú állatokban $(\mathrm{G})$. Hasonló fenotípust figyeltünk meg a $f e o^{E A 86}$ hemizigóta lárvákban (I). Hubsejtek: antiFas3 (kék), Szomatikus sejtek: anti-Tj (piros) Mérték: 10um.

A feo-dsRNS-injektálással előidézett ivarvonal fenotípusát hipomorf mutáns alléllal is reprodukálni tudtuk. Habár a szakirodalmi adatok szerint a feo ${ }^{\text {EA86 }}$ homozigóta és hemizigóta formában bábletalitást okoz [147], tapasztalataink szerint a mutáns állatok már lárvális korban elpusztulnak, ezért hemi- és homozigóta mutánsokat csak embrionális és korai lárvális korban tudtuk vizsgálni. A homoilletve hemizigóta mutáns embriókban a géncsendesítéshez hasonlóan az ivarsejt- 
fejlődés, és ivarszerv-kialakulás normális volt (26.B ábra), azonban a korai lárvális ivarszervekben kisszámú és a normálisnál nagyobb méretű ivarsejtet figyeltünk meg (26.I ábra).

A feo-dsRNS-sel kezelt és a feo mutáns állatok ivarszerveiben a szomatikus eredetủ sejtek tekintetében lényeges különbséget nem fedeztünk fel, ami arra utalt, hogy a feo hatása ivarvonal-függő. Ennek bizonyítását a feo ivarsejt-specifikus géncsendesítével végeztük el. A feo-specifikus UAS-feo-shRNS-t nos-GAL4-VP16 ivarvonal-specifikus meghajtó elemmel kifejeztetve a kifejlett állatok petefészkében a dsRNS-sel és klasszikus mutánssal kapott fenotípushoz hasonló rendellenesen nagyméretű ivarsejteket figyeltünk meg (26.F és F’ábra).

Géncsendesítés hatására a Feo hiányos ivarsejtek sejtmagjában DAPI festéssel megnövekedett mennyiségü DNS volt kimutatható (26.F’ábra). Ennek fényében elképzelhetőnek tartottuk, hogy a Feo hiányában az ivarsejtekben endoreplikációs ciklusok mennek végbe. A centoszómákat jelölő $\gamma$-tubulin ellenanyaggal végzett indirekt immunofluoreszcens jelöléssel azonban kimutattuk, hogy a géncsendesített lárvális petefészkek ivarsejtjeiben gyakran rendellenesen sok centroszóma található, ellentétben a vad típussal, ahol egy, osztódó sejtekben kettő centroszóma jellemzi az ivarsejteket (27. ábra). 

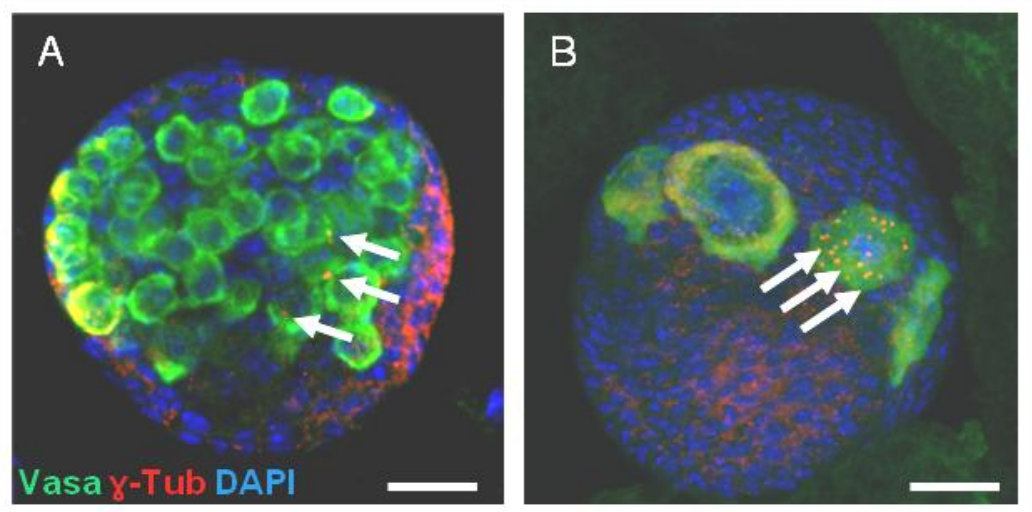

27. ábra: A Feo hiányos ivarvonalsejtek osztódása rendellenes. Centoszóma: anti- $\gamma-T u b u l i n$ (piros), ivarsejtek: anti-Vasa (zöld), DNS: DAPI (kék). Mérték: $20 \mu \mathrm{m}$. A: A vad típusú lárvális petefészekben a centroszómákat általában egy centroszóma jellemzi. B: Ivarvonalspecifikus feo csendesítés hatására a harmadik stádiumú lárvák petefészkében az ivarsejteiben akár tíznél több centroszóma is kimutatható egy ivarsejtben.

Osztódó neuroblaszt sejtekben és elsődleges spermatocitákban a Feo fehérje az osztódási orsó középvonalában lokalizálódik [148]. A Feo fehérje kifejeződési mintázatát megvizsgáltuk az ivarvonal-fejlődés korábbi stádiumaiban. Az embrionális fejlődés során a Feo fehérje az újonnan kialakult csíravonal-sejtekben figyelhető meg először az embrionális fejlődés 4. stádiumában (28.A ábra). Megfigyeléseink szerint a Feo a telofázis során az osztódási orsó középvonalában lokalizálódik. Az embriogenezis későbbi szakaszában az ivarvonalsejtek nem osztódnak, a Feo fehérje nem mutatható ki az interfázisos sejtmagvakban (28.B-C ábra). Később, a korai lárvális ivarszervekben a fehérje ismét kimutatható az osztódó ivarsejtekben. A mitotikus anafázis során a Feo fehérje ebben a fejlődési fázisban is az osztódási orsó középvonalában halmozódik fel (28.D-E ábra). A feo hiányos állatok ivarszervfenotípusai és a fehérje ivarsejtekben megfigyelhető szubcelluláris lokalizációja alapján úgy gondoljuk, hogy a feo gén az ivarsejtek citokinéziséhez szükséges a lárvális herében és petefészekben egyaránt. 

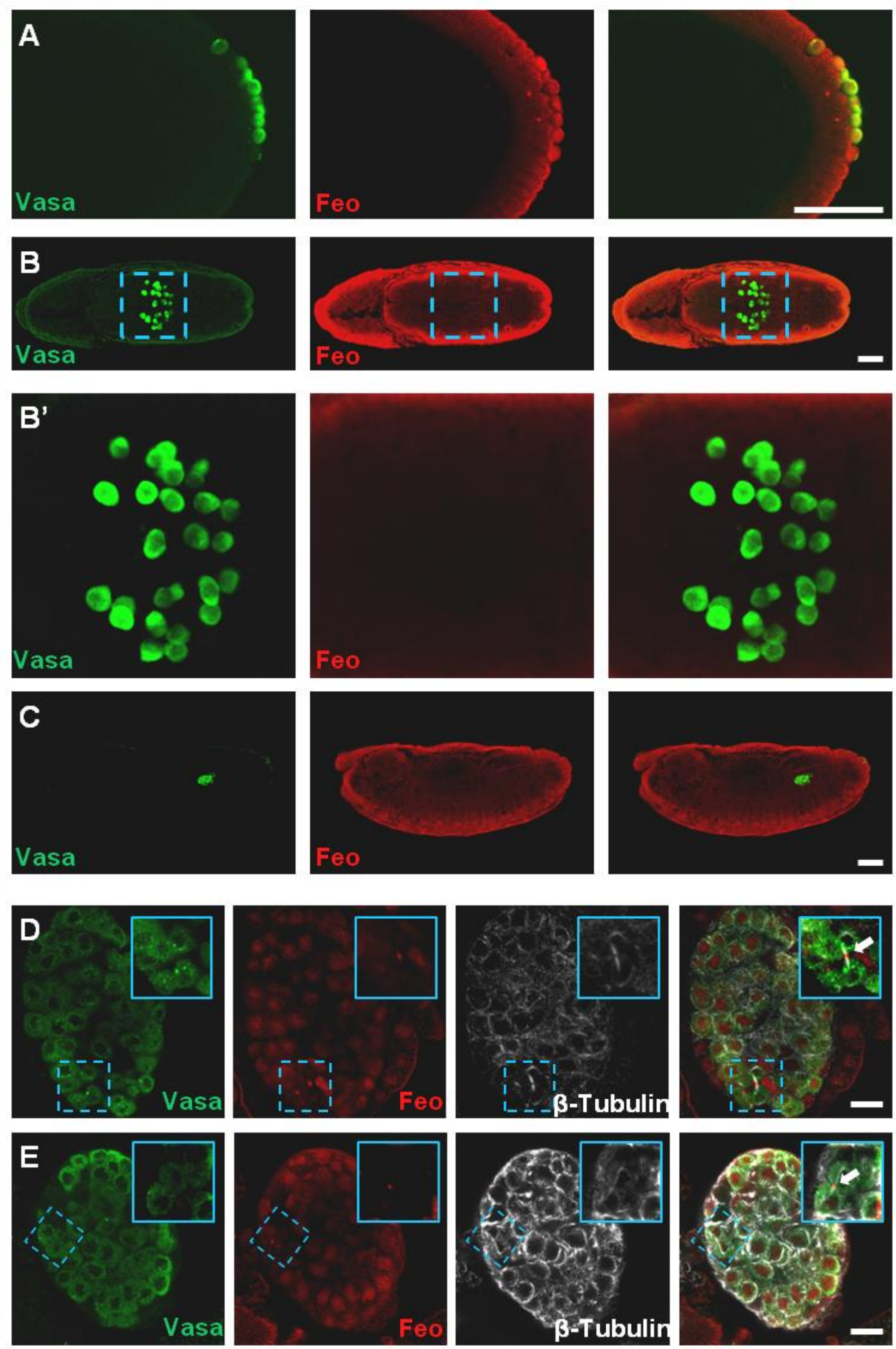

28. ábra: A Feo fehérje kifejeződése a Drosophila ivarvonalban. Ivarsejtek: anti-Vasa (zöld), Feo: anti-Feo (piros). A-C: Embrionális kiefejeződés. A Feo fehérje korai, 4. stádiumú embriók poszterior pólusán, az ivarsejtekben jelen van (A), azonban az embrionális fejlődés későbbi szakaszában (B-C) az ivarsejtekben nem mutatható ki: B: embrionális fejlődés 10. stádiuma ( $\mathrm{B}^{\prime}$ : B ábra kinagyított részlete). C: 16. embrionális stádium. Mérték: $50 \mu \mathrm{m}$. D-E: A fehérje első stádiumos lárvák ivarsejtjeiben újra megjelenik. Mind a lárvális herékben (D), mind a petefészkekben az osztódó ivarsejtek osztódási orsójának (anti- $\beta$-Tubulin: fehér) középvonalában lokalizálódik, amit a kinagyított ábrarészleten nyíl jelöl. Mérték: $10 \mu \mathrm{m}$. 


\subsubsection{A pebble gén szerepe az ivarvonal-fejlődésben}

A pebble $(p b l)$ gén a Rho típusú kis GTPáz fehérjék guanin nukleotid kicserélő faktorát (RhoGEF) kódolja. A fehérje olyan kis GTPase típusú fehérjék (RhoGTPase, RacGTPase) aktiválásában vesz részt, melyek molekuláris kapcsolóként számos sejtbiológiai folyamatban játszanak szerepet. A Drosophila pebble ( $p b l)$ gén funkcióját korábban leírták a sejtosztódás [149,150], valamint a sejtvándorlás során [151,152]. A pbl szerepe e két folyamatban konzervált [153].

A pbl-dsRNS-t korai embriókba injektálva átlagosan 43,6\%-os gyakorisággal figyeltünk meg eltévedt ivarsejteket, az embriók 8,5\%-ban kevés ivarsejtet, illetve 6,5\%-ában az embrionális ivarszervek összerendeződésének hibáit azonosítottuk. E fenotípusok következményeként az embriók 26,6\%-ában nem alakult ki ivarszerv (Függelék 3. táblázat). A csökevényes ivarszerv fenotípust a kifejlett állatokban nem tudtuk vizsgálni, mert a dsRNS injektálása minden esetben az állatok pusztulását okozta. A géncsendesítéssel előidézett összetett fenotípust a $p b l^{3}$ hipomorf allélra [154] homozigóta embriókban szintén kimutattuk. Vasa ellenanyag jelölés segítségével kimértük, hogy a $p b l^{3}$ mutáns embriókban az ivarszerv-kezdemények átlagosan 2,7 ivarsejtet tartalmaztak (n=23), míg a vad típusú embriókban ivarszervkezdeményenként átlagosan 10,5 ivarsejtet figyeltünk meg (n=60). A mutáns embriókban átlagosan 2,3 (n=23) eltévedt ivarsejtet azonosítottunk, míg vad típusban ez a szám átlagosan csupán $0,2(\mathrm{n}=60)$ volt. A SOT érzékenyített genetikai háttéren a $p b l^{3}$ és $p b l^{5}$ hipomorf allélok heterozigóta formában magas gyakorisággal $(43,2$ és $57,7 \%$ ) okoztak ivarsejthiányos fenotípust.

Az embrionális ivarszerv-kezdemény testi sejtjeit jelölő Traffic jam (Tj) ellenanyag jelölés segítségével kimutattuk, hogy $p b l^{3}$ homozigóta embriókban nemcsak az ivarsejtek, de az ivarszervek szomatikus prekurzorai is rendellenes 
eloszlást mutatnak (25.B ábra). Megjegyzendő, hogy a $p b l^{3}$ homozigóta állatok késői embrionális korban elpusztulnak, a késői embrionális hám hibái is jeleznek.
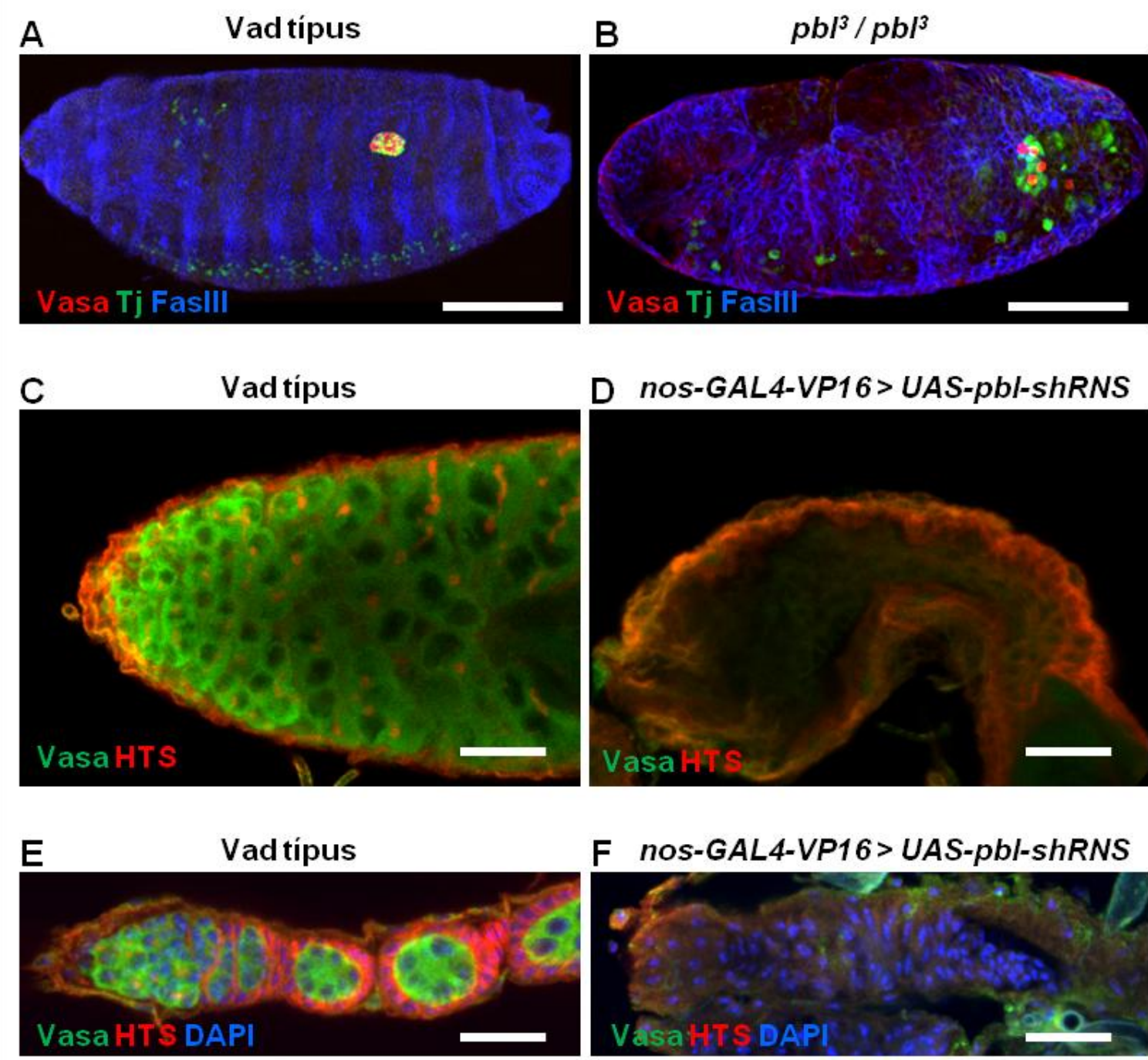

29. ábra: A pbl funkcióvesztéses fenotípusai. A-B: Embrionális fenotípusok. Mérték: $100 \mu \mathrm{m}$. A vad típusú embriókkal szemben (A) a $p b l^{3}$ homozigóta embriók (B) kevesebb ivarsejtet (anti-Vasa: piros) tartalmaznak, melyek szomatikus ivarszerv prekurzorokkal (anti-Tj: zöld) nem alakítanak ki kompakt gonádot. Az embrión a hám hibái is megfigyelhetők (anti-FasIII: kék).

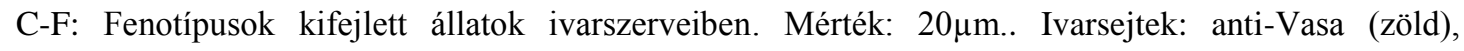
spektroszómák, fuzómák, follikuláris sejtek: anti-HTS (piros). C-D: Fenotípusok kifejlett állatok heréjében. A képeken a herék anterior vége látható. C: Vad típus. D: A pbl ivarvonal-specifikus csendesítés hatására a here csökevényes és ivarsejteket nem tartalmaz. E-F: Vad típusú (E) és $p b l$ shRNS által előidézett fenotípus (F) kifejlett állatok germáriumában. A $p b l$ ivarvonal-specifikus csendesítésekor a germáriumban ivarsejtek nem mutathatóak ki. 
A dsRNS injektálással és klasszikus allélokkal kapott eredményeink egyaránt arra utalnak, hogy az embrionális ivarsejt-fenotípusok legalább részben a $p b l$ gén testi sejtekben betöltött szerepének következményei. Hogy a pbl gén ivarvonalban betöltött szerepét bemutassuk, nos-GAL4-VP16 GAL4-forrás segítségével pbl-shRNS-t fejeztettünk ki az ivarvonalban. A géncsendesített felnőtt állatok petefészkei és heréi minden esetben csökevényesek voltak $(n=60)$, Vasa ellenanyag-jelöléssel ivarsejteket nem tudtunk kimutatni egyik nemben sem (29.C-F ábra). Mivel az ivarvonalban zigotikusan kifejeztetett shRNS-en keresztüli géncsendesítés embrionális korban nem müködik, a dsRNS-sel, valamint a klasszikus mutáns allélokkal megfigyelt $p b l$ embrió fenotípusok ivarsejt-függő voltát nem lehetett bizonyítani. A felnőtt korban megfigyelt teljes ivarsejthiányos, shRNS indukálta fenotípus azonban bizonyítja, hogy a pbl gén ivarsejt-függő módon is hozzájárul az ivarvonal fejlődéshez.

A FlyFish RNS in situ hibridizációs adatbázis szerint a $p b l$ mRNS-e a Drosophila embriókban általánosan kifejeződik, de az embrionális a testi sejtekhez képest az ivarsejtekben jelentős felhalmozódást mutat. Eredményeink és a $p b l$ mRNS kifejeződési mintázata alapján valószínűsíthető, hogy az embrionális ivarsejtek számának csökkenése és a későbbi fejlődés során az ivarsejtek eltünése az ivarszervekből a $p b l$ génfunkció ivarsejt-specifikus hiányának tudható be, míg az embrionális ivarszerv összerendeződésének hibái a Pbl hiányos testi sejtek számlájára írhatók.

\subsubsection{A mei-P26 gén funkciója az embrionális és lárvális ivarvonalban}

A mei-P26 gén az evolúciósan konzervált TRIM-NHL domént tartalmazó fehérjét kódol. A Drosophila nőstény ivarvonal-fejlődésben betöltött összetett szerepét kimutatták kifejlett állatok ováriumában: A mei-P26 egyrészt ivarsejt-függő 
módon szabályozza az ovárium ivarvonal-őssejtjeinek fennmaradását, amit a BMP jelátviteli útvonal fenntartása által tölt be [128]. Másrészt a Mei-P26 fehérje a miRNS útvonal regulátoraként hozzájárul a csíravonal őssejtek és cisztasejtek differenciálódásához [129,130]. A mei-P26 ivarvonalban betöltött funkcióját egyedfejlődés korábbi szakaszában (embrionális, lárvális fejlődés alatt) korábban nem mutatták ki. A BDGP génexpressziós adatbázis szerint a mei-P26 mRNS 1-8 stádiumú embriók ivarsejtjeiben fejeződik ki (Függelék 4. táblázat). A Mei-P26 fehérje részletes kifejeződési mintázatát indirekt immunofluoreszcencia módszer segítségével vizsgáltuk. A fehérje jelenléte a korai, 0-1 órás (1-4. stádiumú) embrióban nem mutatható ki, de a testüregben vándorló ivarsejtekben a fehérje már megjelenik és citoplazmás eloszlást mutat (30.A és B ábra). A Mei-P26 fehérje expressziója az embrionális ivarsejtekben az embriogenezis végéig fennmarad (30.C ábra).

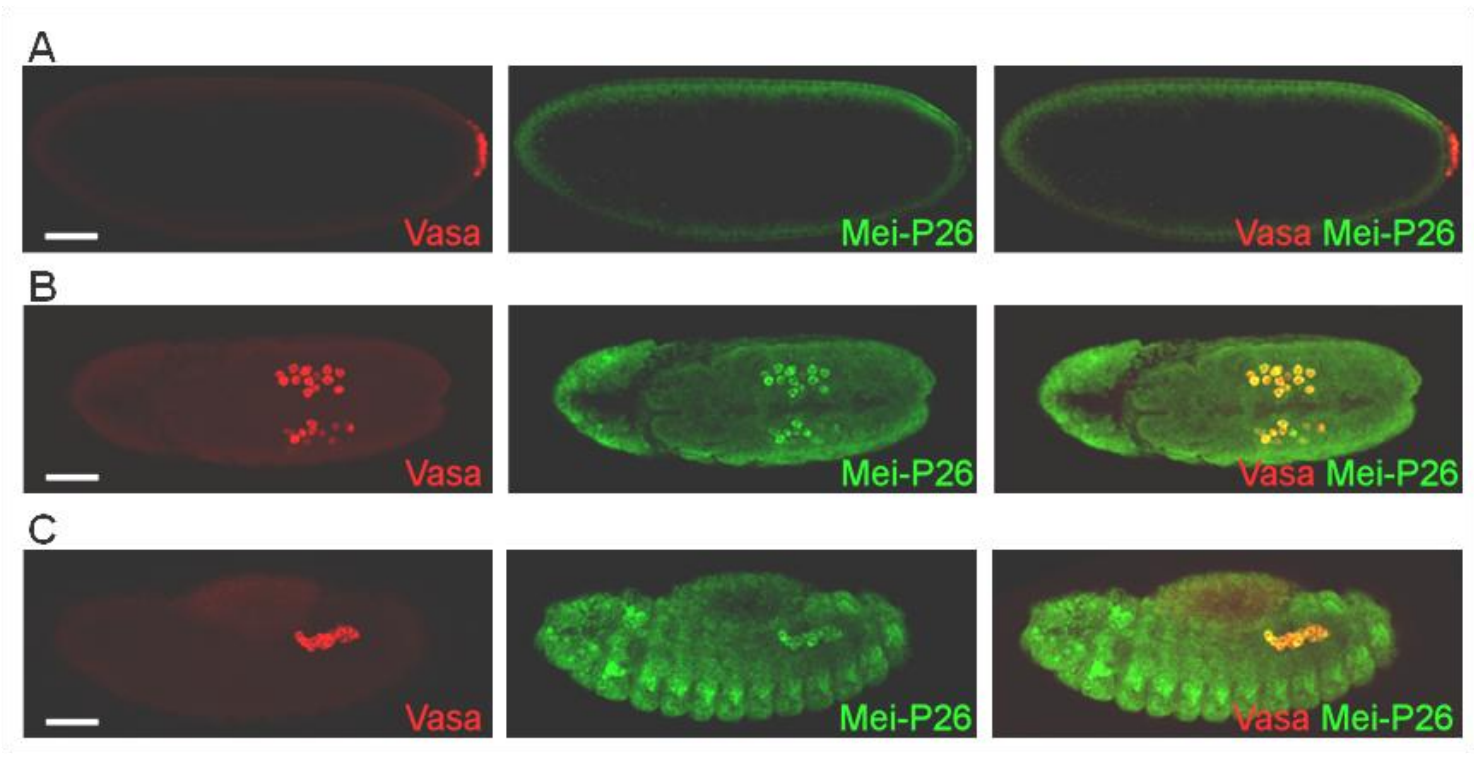

30. ábra: A Mei-P26 fehérje kifejeződése embrionális ivarsejtekben. Ivarvonalsejtek: anti-Vasa (piros), Mei-P26: anti-Mei-P26 (zöld) A: A Mei-P26 fehérje a 4. stádiumú korai embriók poszterior végen lefüződő ivarvonalsejtjeiben (anti-Vasa: piros) nem mutatható ki. B: A fehérje detektálható a vándorló ivarsejtekben (11. stádium). C: A Mei-P26 fehérje szintén jelen van a kialakuló embrionális ivarszervek ivarsejtjeiben (14. stádium). Mérték: $50 \mu \mathrm{m}$. 
Noha a mei-P26 gén az embrionális fejlődés során kifejeződik, az embrionális ivarsejt-fejlődés során betöltött szerepét még nem írták le. Géncsendesítési kísérletsorozatunk során kimutattuk, hogy a mei-P26 az embrionális ivarsejtek fejlődésében is részt vesz. A dsRNS interferencia kísérletsorozatban a meiP-26 gén csendesítése az embriók 21,3\%-ban az ivarsejtek számának csökkenését okozta (Függelék 3. táblázat). Konfokális mikroszkópiával kimutattuk, hogy a mei-P26dsRNS-sel injektált embriókban nemcsak az ivarsejtek száma csökken, de azok gyakran rendellenes elhelyezkedésűek (31.A-D ábra). Előfordul, hogy az embrionális ivarvonalsejtek képtelenek kialakítani az embrionális ivarszervet (Függelék 3. táblázat). Hasonló fenotípusok figyelhetők meg a nos mutáns nőstények utódaiban is [78,95,155], ahol a az anyai eredetü nos hiányában az embrionális ivarsejtek szomatikus irányba differenciálódnak, és osztódásba kezdenek, amit egy mitotikus ciklinnek, a CycB-nek kifejeződése jelez. Hayashi és munkatársai kimutatták, hogy a nos deficiens, ivarsejt identitást elvesztett sejtek apoptózissal elpusztulnak [156]. CycB ellenanyag festéssel kimutattuk, hogy a mei-P26-dsRNS-sel injektált embriók ivarsejtjeiben, a nos deficiens ivarsejtekhez hasonlóan [155], jelen van CycB fehérje (31.C-D ábra). Eredményeink arra utalnak, hogy a mei-P26 az ivarsejtsors fenntartásában és szomatikus irányba történő differenciálódás gátlásában játszik szerepet. A mei-P26 csökkent ivarsejtszám fenotípusát a szomatikus irányba differenciálódó ivarsejtek apoptózisával magyarázzuk, amit a CycB fehérje a vándorló embrionális ivarvonalsejtekben megfigyelhető kifejeződése igazol.

Lárvális és báb ivarszervekben is megvizsgáltuk a Mei-P26 fehérje kifejeződését. Lárvális herékben gyenge citoplazmás Mei-P26 expresszió detektálható a csíravonal őssejtekben. A differenciálódó spermatogóniumokban erőteljes kifejeződés figyelhető meg, a fehérje a sejtmagokban van jelen (32.A ábra). A késői 
harmadik stádiumos lárvák petefészkében a fehérje az ivarsejtek citoplazmájában lokalizálódik (32.B ábra).
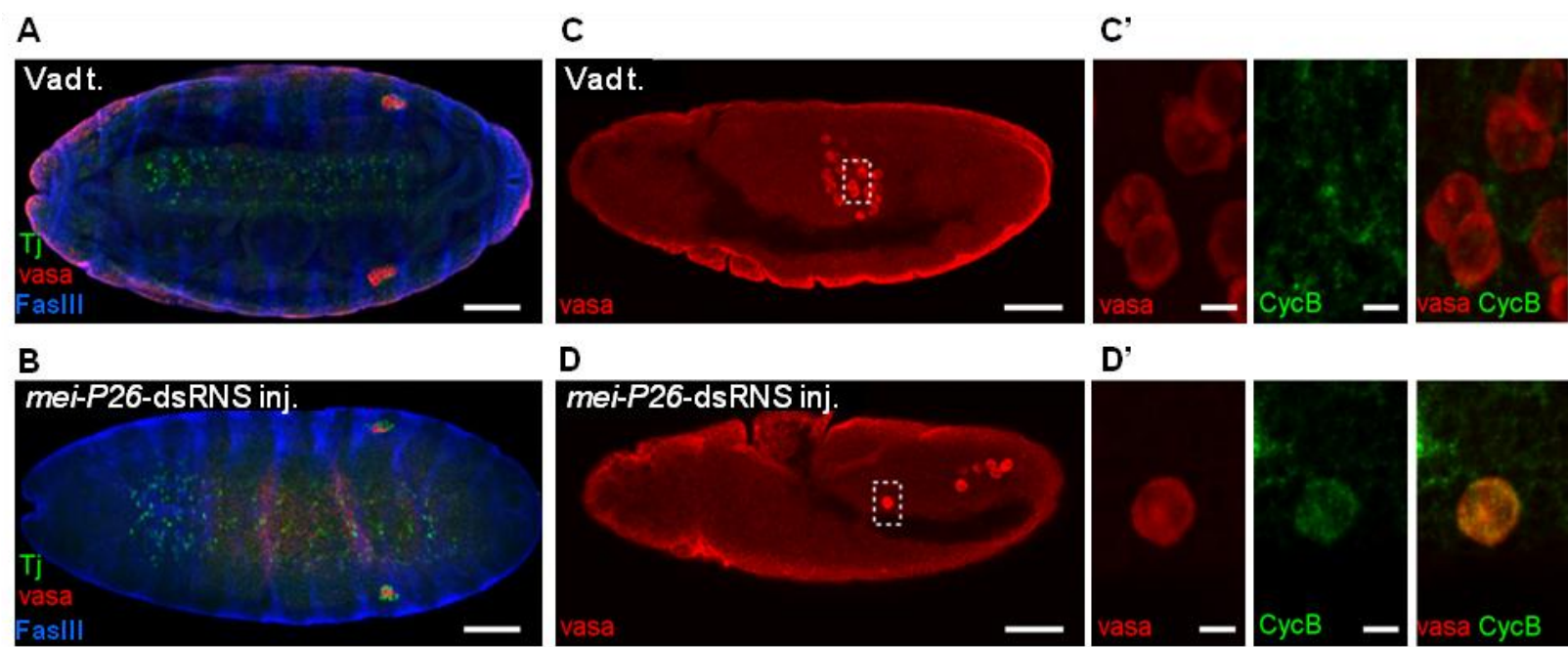

D'
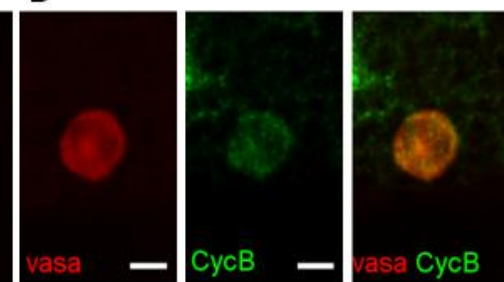

31. ábra: A mei-P26-dsRNS által indukált embrionális fenotípus. A mei-P26-dsRNS-sel injektált embriókban (B, D) az ivarsejtek száma (anti-Vasa: piros) csökken vad típushoz képest (A, D). C-D: A CycB kifejeződése vándorló ivarvonalsejtekben. C' és D': C és D ábra kinagyított részletei. A vad típusú állatokkal (C') ellentétben az injektált állatok (D'), ivarsejtjei $\mathrm{CycB}$ fehérjét (anti-CycB: zöld) fejeznek ki az embrionális fejlödés 12. stádiumában amely az osztódó sejtek jellegzetes markere. Mérték: $50 \mu \mathrm{m}$ (A-D) és $5 \mu \mathrm{m}$ (C' és D').
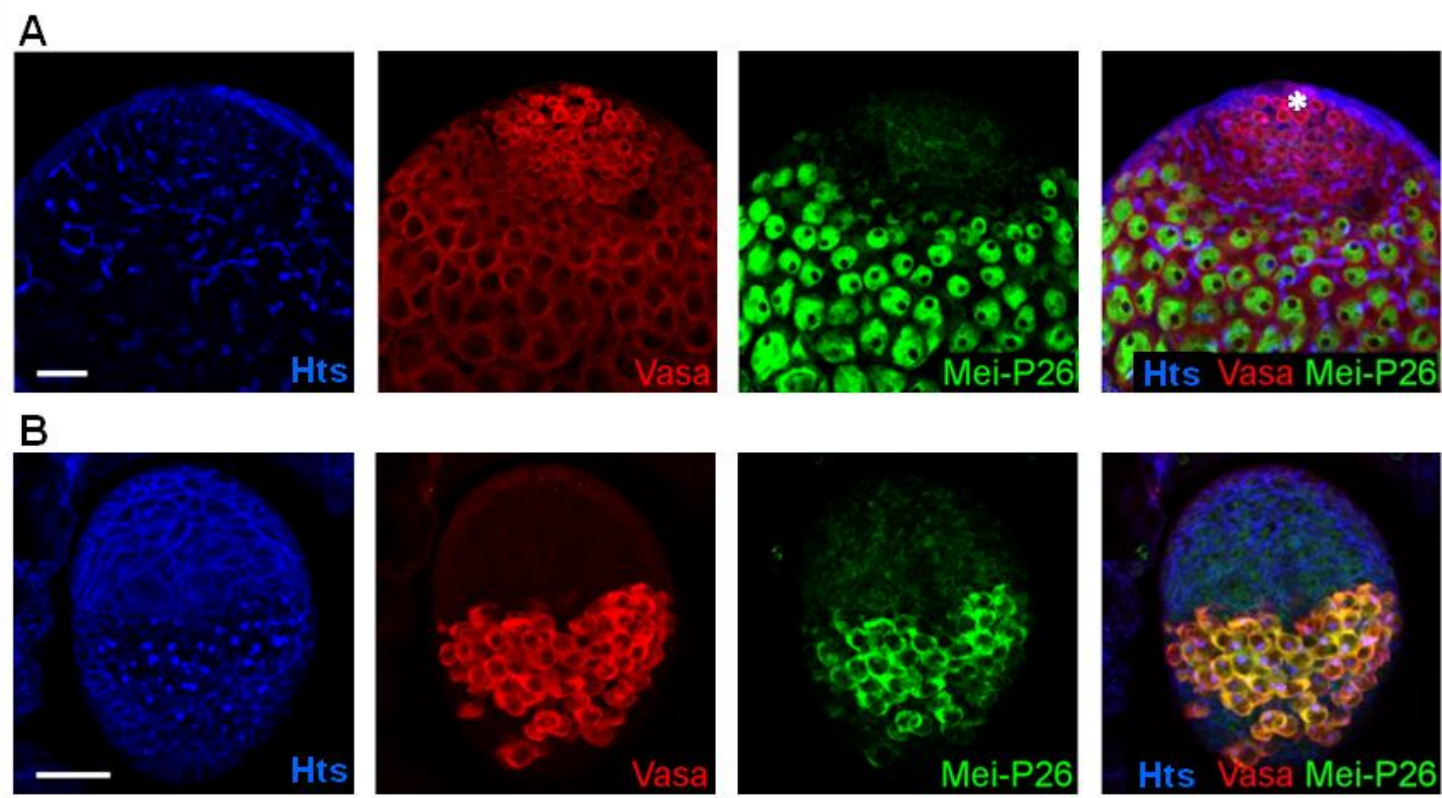

32. ábra: A Mei-P26 fehérje kifejeződése lárvális ivarszervekben. A harmadik stádiumú lárvák heréjében (A) gyenge Mei-P26 expresszió figyelhető meg a here anterior csúcsán (fehér csillag) elhelyezkedő csíravonal őssejtekben és a goniálblasztokban. A differenciálódó spermatogóniumokban azonban a Mei-P26 erőteljesen kifejeződik. A harmadik stádiumos lárvák petefészkében (B) a Mei-P26 az ivarsejtekben fejeződik ki. Az ivarvonal össejteket és közvetlen leszármazottaikat, a cisztoblasztokat (petefészek) és goniálblasztokat (here) pontszerủ spektroszómák jellemzik, míg a lárvális herében,

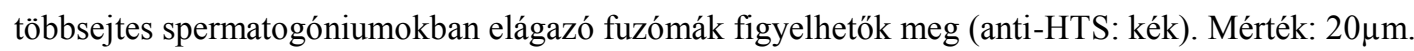


Lárvális és báb ivarszervekben is megvizsgáltuk a Mei-P26 fehérje kifejeződését. Lárvális herékben gyenge citoplazmás Mei-P26 festődés detektálható a csíravonal őssejtekben. A differenciálódó spermatogóniumokban erőteljes kifejeződés figyelhető meg, a fehérje a sejtmagokban van jelen (32.A ábra). A késői harmadik stádiumos lárvák petefészkében a fehérje az ivarsejtek citoplazmájában mutatható ki (32.B ábra). A mei-P26-dsRNS-sel kezelt állatok lárvális petefészkei csökevényesek: kevés Vasa pozitív ivarsejtet tartalmaznak, de teljesen ivarsejthiányos ivarszervek is előfordulnak (33.B ábra). Kísérleteink alapján, a mei-P26 géntermék hiánya az egyedfejlődés során az ivarsejtvonal sejtek progresszív eltünését eredményezi. Ivarsejtvonal-specifikus géncsendesítéssel vizsgáltuk, hogy a mei-P26 gén ivarsejtfüggő módon járul-e hozzá az ivarsejtvonal fenntartásához. Ezért a transzgenikus UASp-mei-P26-shRNS transzgént a nos-GAL4-VP16 ivarvonal-specifikus GAL4forrással fejeztettük ki. Az ivarvonal-specifikus géncsendesítés megegyező fenotípust okozott lárvális petefészkekben azzal, mint mikor a mei-P26-dsRNS az embriókba injektáltuk (33.C ábra). Ez arra utal, hogy a gén kifejeződésére az ivarsejtekben van szükség az ivarsejtsors fenntartásához. Lárvális herékben szintén az ivarsejtek számának csökkenését figyeltük meg, mind mei-P26-dsRNS injektálása, mind meiP26-shRNS ivarvonal-specifikus kifejeztetése esetén (33.D-F ábra). 

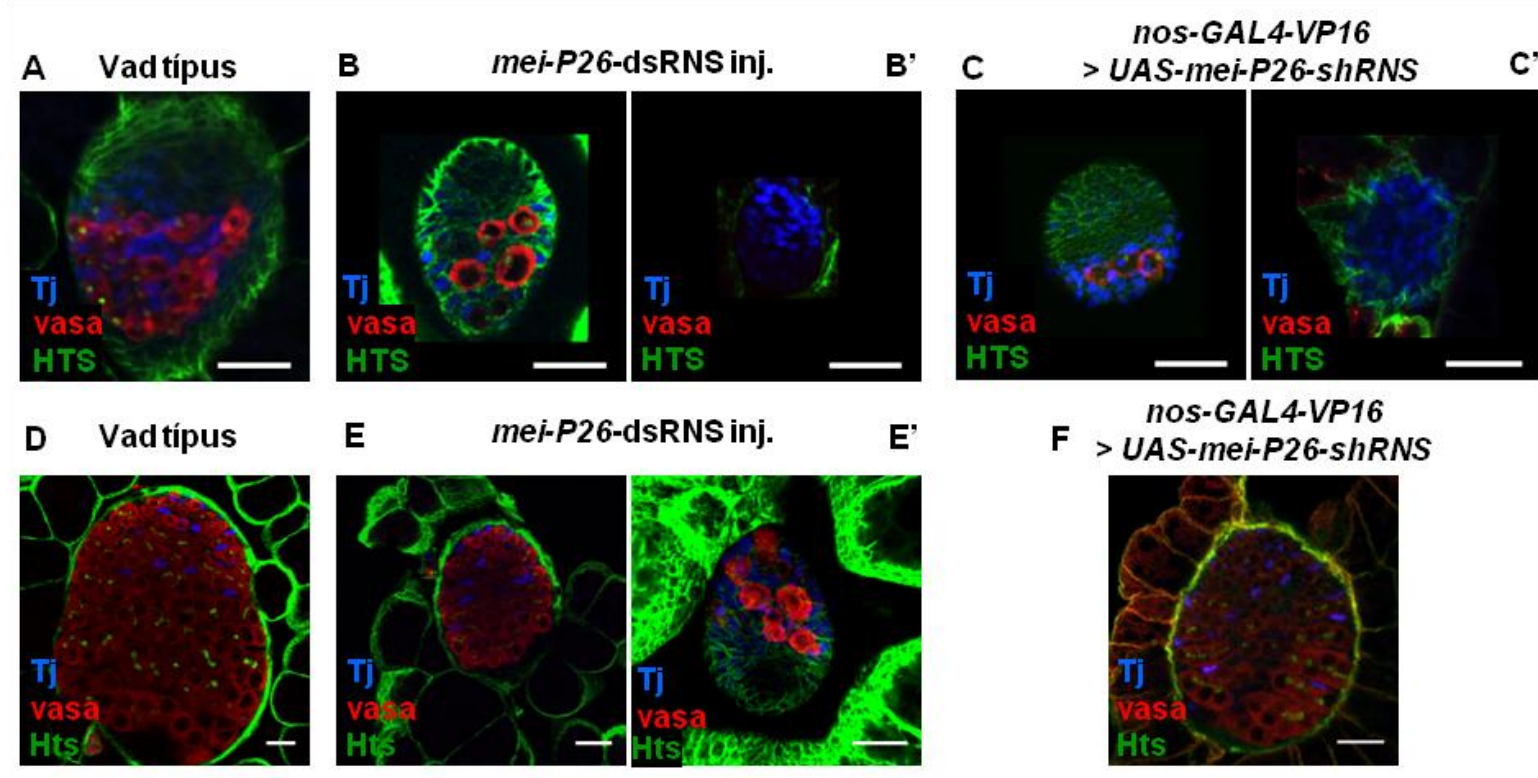

G
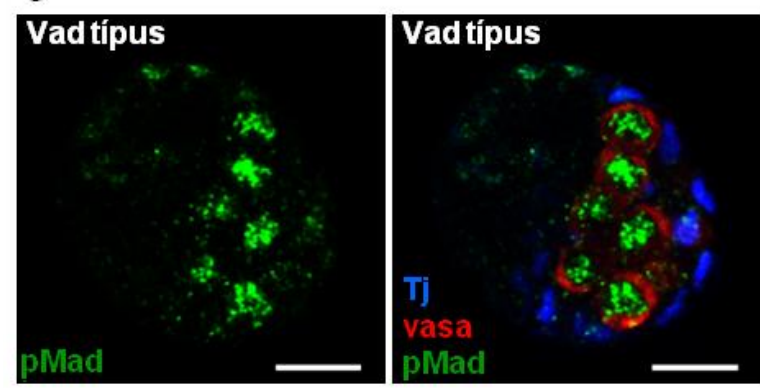

H

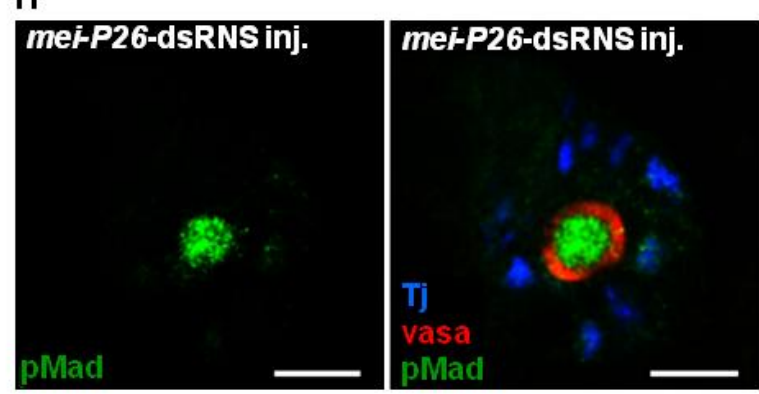

33. ábra: A mei-P26 géncsendesítés okozta fenotípusok a lárvális ivarszervekben. A-F: Harmadik stádiumos lárvális petefészkek (A-C) és herék (D-F). Ivarvonalsejtek: anti-Vasa (piros), spektroszómák,

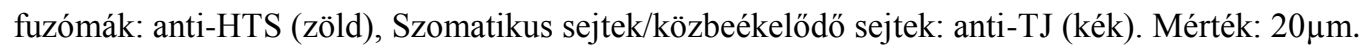

A-C: lárvális petefészkek: A vad típushoz (A) képest kevesebb ivarsejtet tartalmaznak a mei-P26-dsRNS-sel injektált állatok petefészkei (B és B'). Hasonló fenotípus figyelhető meg, azokban az állatokban, melyekben mei-P26 gént ivarsejt-specifikusan shRNS segítségével csendesítjük ( $\mathrm{C}$ és C'). Mindkét típusú géncsendesítésnél megfigyeltünk teljesen ivarsejthiányos ivarszerveket (B' és $\left.C^{\prime}\right)$ is.

D-F: lárvális herék: D: vad típus. A harmadik stádiumos lárvákban dsRNS injektálás (E és E’) és az ivarsejtspecifikus shRNS alapú mei-P26 csendesítés (F) egyaránt az ivarsejtek számának csökkenését eredményezte. Megfigyelhető volt a többsejtes ciszták kialakulásának hiánya is (E').

G-H: Vad típushoz hasonlóan (G) mei-P26 dsRNS-sel kezel állatok harmadik stádiumos lárvális petefészkében $(\mathrm{H})$ az ivarsejtek kifejezik a foszforilált-Mad fehérjét (anti-pMad: zöld). Mérték: 10 $\mu \mathrm{m}$.

Kifejlett állatok ováriumában a csíravonal őssejtek fenntartásához a BMP jelátviteli útvonal szükséges [36]. A szomszédos szomatikus eredetű sapkasejtek felől érkező Dpp/Gbb szignál hatására a csíravonal őssejtekben a foszforilált-Mad (pMad) fehérje gátolja a differenciálódáshoz szükséges bag of marbles (bam) gén kifejeződését. Li és munkatársai kimutatták, hogy mei-P26 mutáns felnőtt 
petefészekben a csíravonal őssejtek nem tudnak fennmaradni, mert a BMP útvonal nem aktiválódik azokban [128]. Megvizsgáltuk, hogy a mei-P26 mutáns kifejlett állatok csíravonal őssejtjeihez hasonlóan, a lárvális őssejtekben sem aktiválódik-e a BMP útvonal. Foszforilált Mad-et felismerő (anti-pMad) ellenanyag segítségével meiP26-dsRNS-sel csendesített késői harmadik stádiumú lárvákban kimutattuk, hogy a BMP szignalizáció az ivarvonal őssejtekben aktív, tehát ezen sejtek fennmaradásához a mei-P26 nem a BMP szignalizáció fenntartásán keresztül járul hozzá (29.G-H. ábra).

\subsubsection{A szumoiláció szerepe az ivarvonal-fejlődésben}

Géncsendesítő kísérletsorozatunkban két gént azonosítottunk, melyek a szumoilációs enzimeket kódolnak. A szumoiláció evolúciósan konzervált, reverzibilis posztranszlációs fehérjemódosító mechanizmus. Az ubikvitilációs rendszerhez hasonlóan egy aktiváló enzimkomplex (E1) egy konjugáló enzim (E2) és egy ligáz enzim segítségével (E3) a kis molekulasúlyú SUMO fehérje kovalensen kötődik a célfehérjékhez, így megjelölve azokat (34. ábra). Az ubikvitilációtól eltérően azonban a szumoilált célfehérjék elsősorban nem degradálódnak, hanem szubcelluláris lokalizációjuk, aktivitásuk, vagy éppen stabilitásuk változik meg. A Drosophila genomban egy SUMO fehérjét kódoló gén található, az smt3. A SUMO-aktiváló (E1) enzim két alegységét az Aos1 és az Uba2 gének, míg a SUMO-konjugáló (E2) enzimet a lesswright (lwr) gén kódolja. Drosophilában mindössze két olyan gén ismeretes, amelyek fehérjeterméke bizonyítottan SUMO-ligáz (E3) aktivitással rendelkezik, ezek a Suppressor of variegation 2-10 (Su(var)2-10) és a tonalli (tna) gének. Az eddig vizsgált eukarióta szervezetekhez hasonlóan, a szumoiláció a Drosophilában is esszenciális fejlődésbiológiai folyamat. A szumoiláció szerepet 
játszik többek között a homeotikus gének kifejeződésének szabályozásában, a kromoszóma-struktúrák fenntartásában, valamint a jelátviteli útvonalak, és a sejtciklus szabályozásában [157]. A szumoiláció szerepét kimutatták a Drosophila embriógenezisben, a szárnyfejlődésben, az idegrendszer-fejlődésében továbbá az immunválaszban [158]. Hashiyama és munkatársai kimutatták, hogy az Aosl (E1 alegység), az Uba2 (E1 alegység), és a lwr (E2) mRNS szinten, továbbá az smt3 (SUMO) mRNS és fehérje szinten kifejeződnek a Drosophila embrionális ivarsejtjeiben, továbbá a kifejlett állatokban, az oogenezis és spermatogenezis során [159].

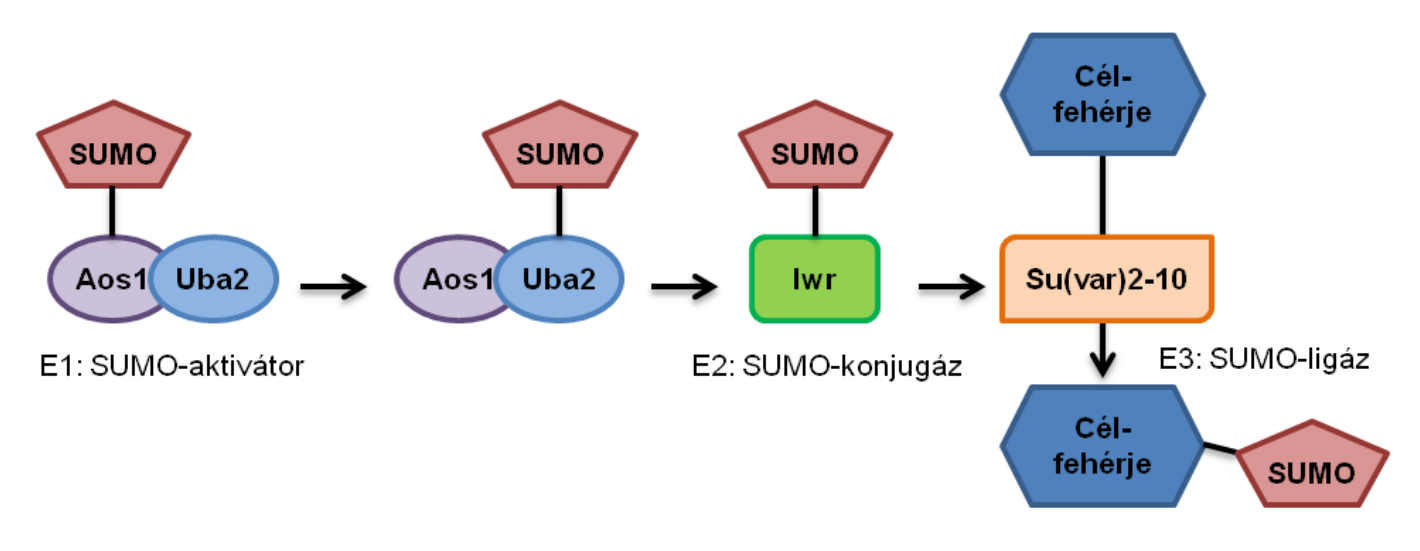

34. ábra: Szumoilációs útvonal Drosophilában

A dsRNS alapú géncsendesítő kísérletsorozatunk 48 jelölt génje között két Szumoilációs enzimet kódoló gén, a $\operatorname{Su}($ var)2-10 és az Aos1 található. A Su(var)2-10 (E3 SUMO ligáz) elleni dsRNS injektálása embrionális ivarsejt-fejlődésben nem okozott rendellenességeket, viszont az injektált állatok kifejlett korban átlagosan 38,1\%-os gyakorisággal tartalmaztak csökevényes ivarszerveket. Az Aos1 (E1 SUMO aktiváló enzim) csendesítésével szintén erős, 17,9\%-os ivarsejthiányos fenotípust figyeltünk meg a kifejlett állatokban. Az Aosl-dsRNS-sel történő csendesítés során embrionális korban 28,7\%-os gyakorisággal eltévedt ivarsejteket hordozó embriókat kaptunk (Függelék 3. táblázat). Az RNSi kísérletsorozatban csendesítettük az Uba2, 
$l w r$ és smt3 géneket is, de az injektált állatok korai elpusztulása miatt ivarsejthiányos fenotípust nem tudtunk kimutatni a kifejlett egyedekben.

A SUMO fehérje kifejeződési mintázatát kifejlett állatok ivarszerveiben vizsgáltuk a SUMO-fehérjét felismerő anti-smt3 ellenanyag segítségével. A SUMO fehérje a here ivarsejtjeiben (csíravonal őssejtek, goniálblasztok, spermatogónium) sejtmagi lokalizációt mutatott (35.B ábra). Petefészkekben azt tapasztaltuk, hogy a SUMO fehérje jelen van mind az ivarsejtvonal sejtjeiben (csíravonal őssejtek, cisztoblasztok és cisztasejtek), mind a szomatikus eredetű follikuláris sejtek magjaiban (35. A ábra).
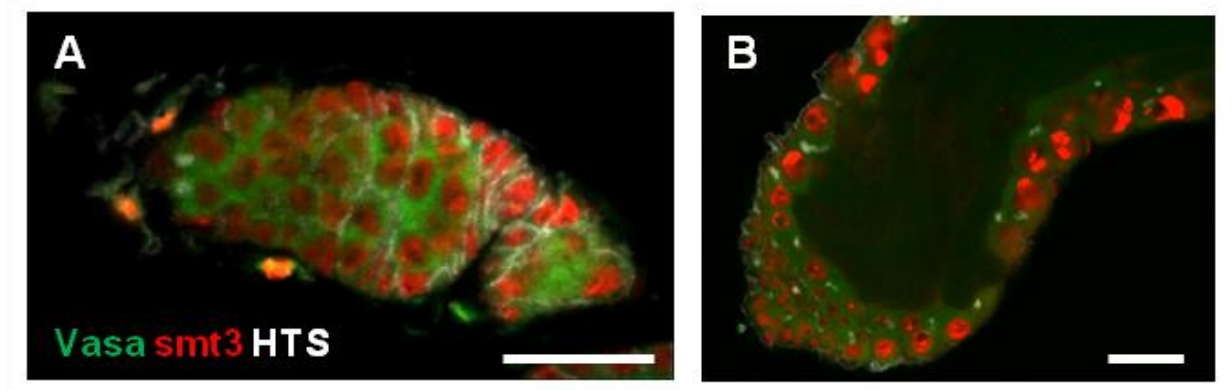

35. ábra: Az smt3 gén által kódolt SUMO fehérje kifejeződése a kifejlett állatok germáriumában és heréjében. Ivarsejtek: anti-Vasa (zöld); Sumo fehérje: anti-smt3 (piros); spektroszóma, fuzóma, follikuláris sejtek sejthártyája: anti-HTS (fehér). Mérték: $20 \mu \mathrm{m}$. A: A germáriumban a SUMO fehérje a csíravonal őssejtek, a cisztoblasztok, cisztasejtek és a follikuláris sejtek sejtmagjában is jelen van. B: A SUMO fehérje kifejlett állatok heréjének csúcsi részén elhelyezkedő összes ivarvonalsejt magjában kimutatható.

A szumoiláció ivarszerv-fejlődésben betöltött szerepét a szumoilációs enzimeket kódoló gének elleni shRNS-ek ivarvonal-specifikus kifejeztetésével is vizsgáltuk. A nos-GAL4-VP16 Gal4-forrással az smt3, Aos1, Uba2 és Su(var)2-10 gének elleni shRNS-ek kifejeztetése csökevényes ivarszervek kialakulását eredményezte kifejlett állatokban (6. táblázat). E gének csendesítésének hatását indirekt immunofluoreszcens festéssel vizsgáltuk harmadik stádiumos lárvák, illetve 
kifejlett állatok ivarszervein. Kontrollként az azonos keresztezésből származó, a shRNS helyett TM3 balanszer-kromoszómát hordozó állatok ivarszervei szolgáltak.

\begin{tabular}{|c|c|c|c|c|c|}
\hline \multirow{3}{*}{ Csendesített gén } & \multirow{3}{*}{ shRNS } & \multicolumn{4}{|c|}{ nos-GAL4-VP16 } \\
\hline & & \multicolumn{2}{|c|}{ Petefészek } & \multicolumn{2}{|c|}{ Here } \\
\hline & & $\mathbf{n}$ & $\%$ & $\mathbf{n}$ & $\%$ \\
\hline $\operatorname{Aos} 1$ & GL00493 & 39 & 100 & 30 & 100 \\
\hline Su(var)2-10 & HMS00705 & 24 & 100 & 19 & 100 \\
\hline Su(var)2-10 & HMS00750 & 30 & 100 & 26 & 100 \\
\hline smt3 & HMS01540 & 30 & 100 & 30 & 100 \\
\hline Uba2 & GL00452 & 30 & 100 & 30 & 100 \\
\hline$l w r$ & GL00624 & 30 & $\mathbf{0}$ & 30 & $\mathbf{0}$ \\
\hline$l w r$ & HMS01648 & 30 & $\mathbf{0}$ & 30 & $\mathbf{0}$ \\
\hline Kontrol $\left(T M 3 S^{I}\right)$ & - & 30 & $\mathbf{0}$ & 30 & $\mathbf{0}$ \\
\hline
\end{tabular}

6. táblázat: A szumoilációs fehérjéket kódoló gének csendesítése ivarvonalban nos-GAL4-VP16 GAL4-forrással kifejeztetett transzgenikus shRNS-ek által. n: felboncolt petefészekpár vagy here; \%: a csökevényes ivarszervek előfordulási aránya százalékban kifejezve.

Az smt3 gén csendesítésének hatására a lárvális petefészkek és herék Vasaellenanyaggal azonosítható ivarvonalsejteket nem tartalmaztak (36.B, 37.B ábrák), ezért a kifejlett állatok ivarszervei is ivarsejthiányosak voltak (36.G és 37.G ábrák). Az Aos1, Uba2 és $S u(v a r) 2-10$ gének csendesítése azonban ettől némiképp eltérő fenotípust eredményezett. Harmadik stádiumú lárvális petefészkekben egyik gén csendesítése sem okozta az ivarvonalsejtek eltűnését. Az őssejteket jellemző HTS pozitív spektroszómákat azonosítottuk ezekben a sejtekben (36.C-E ábrák). A kifejlett állatok petefészkei azonban erősen ivarsejthiányosnak bizonyultak, petefészkenként legfeljebb néhány petecső germáriumában figyeltünk meg Vasa pozitív ivarsejteket (36. H'-J' ábrák). Az ivarsejtek egy részében a spektroszómákat is azonosítottuk, de elágazó struktúrájú fuzómákat nem figyeltünk meg, ami az ivarsejt-differenciálódás hiányát jelzi. 


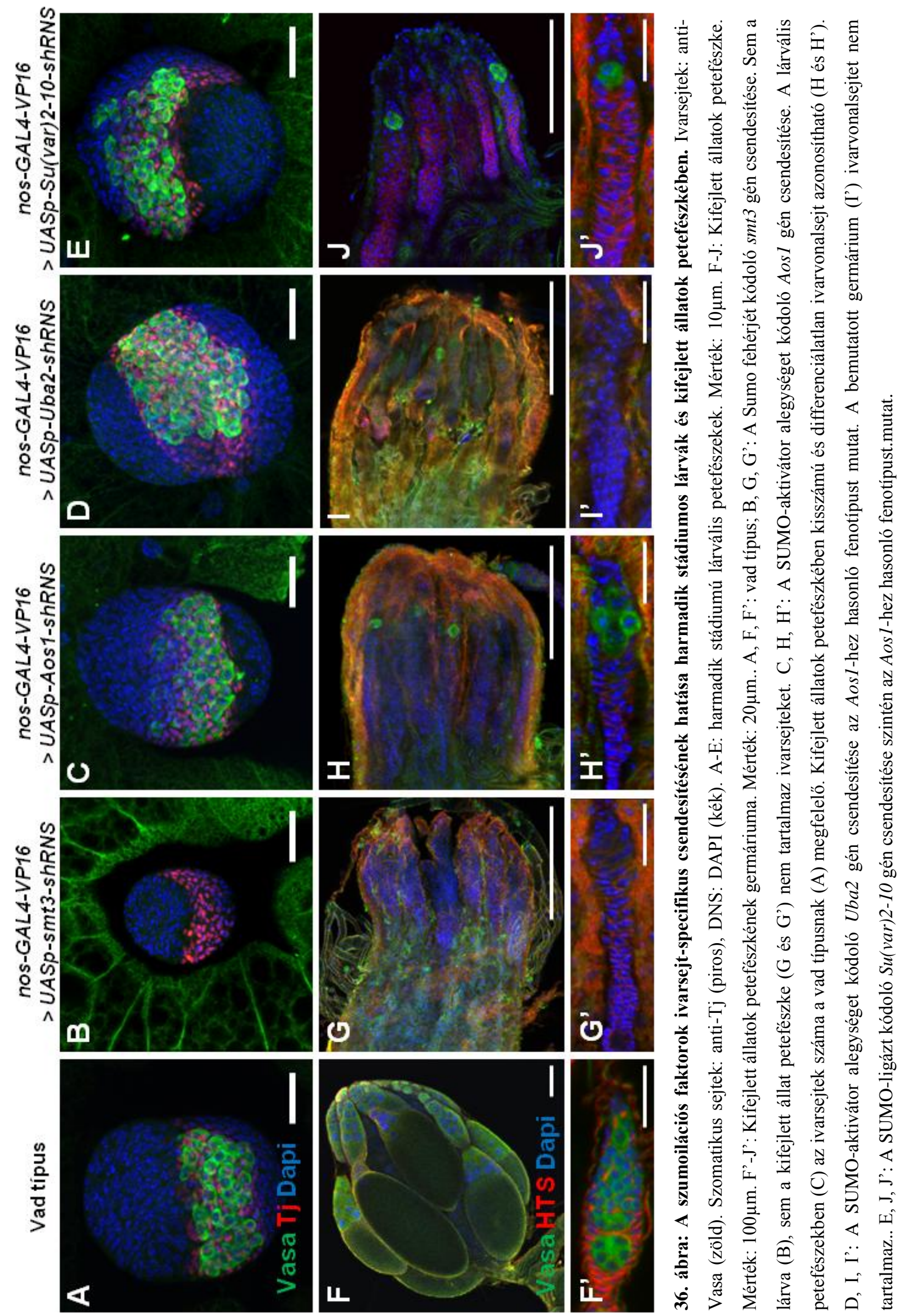


Az Aos1, Uba2 és Su(var)2-10 gének csendesítése a hím ivarvonalban szintén egységes fenotípust mutatott. Lárvális herékben a kisméretü Vasa pozitív ivarsejtek hiányoztak a here anterior pólusáról, ellenben a here középső és poszterior részében a nagyobb méretü, differenciálódó spermatogónium sejtek megfigyelhetőek voltak. A spermatogónium sejteket a rajtuk átívelő elágazódó fuzómák jellemezték (37.C-E ábrák). Kifejlett hímek ivarszerveiben az Aos1, Uba2 és Su(var)2-10 gének csendesítésekor megint csak azonos fenotípust figyeltünk meg. A herék nagymértékben csökevényesek voltak, azonban $\beta$-tubulin ellenanyaggal végzett jelöléssel kimutattuk, hogy a herében kevés számú, de megnyúlt spematid volt jelen. Rhodamine-phalloidine festéssel a spermatid megnyúlást jellemző aktinkúpukat nem figyeltünk meg, ami arra utal, hogy korábbi fejlődési stádiumban lévő ivarsejtek nem voltak a géncsendesítésen átesett állatokban. Ez azt jelenti, hogy a spermiumképződés utánpótlása megszünt (37.H-J ábrák). Azon hímek, melyek ivarvonalában az Aos1, Uba2 és Su(var)2-10 géneket csendesítettük, vad típusú (Oregon-R) szüz nőstényekkel keresztezve sterilnek bizonyultak, annak ellenére, hogy az állatok heréjében kisszámú, de jól fejlett spermatidot/spermiumot megfigyeltünk. A SUMOkonjugáló enzimet kódoló $l w r$ gént két transzgenikus shRNS-sel próbáltuk csendesíteni ivarsejt-specifikusan, azonban egyik esetben sem figyeltünk meg a vad típustól eltérő fenotípust. Feltehetően ezek a géncsendesítő shRNS-sek nem müködtek hatékonyan. Az UAS-lwr-shRNS-ek hatástalanságát alátámasztja, hogy a testi sejtekben általánosan kifejeződő Act-GAL4 driverrel meghajtva nem mutattak letális fenotípust. A többi vizsgált, szumoilációs faktor elleni shRNS Act-GAL4 driverrel kifejeztetve lárvális letalitást okozott, amely megfelel a funkcióvesztéses allélok által előidézett fenotípusnak (FlyBase). 


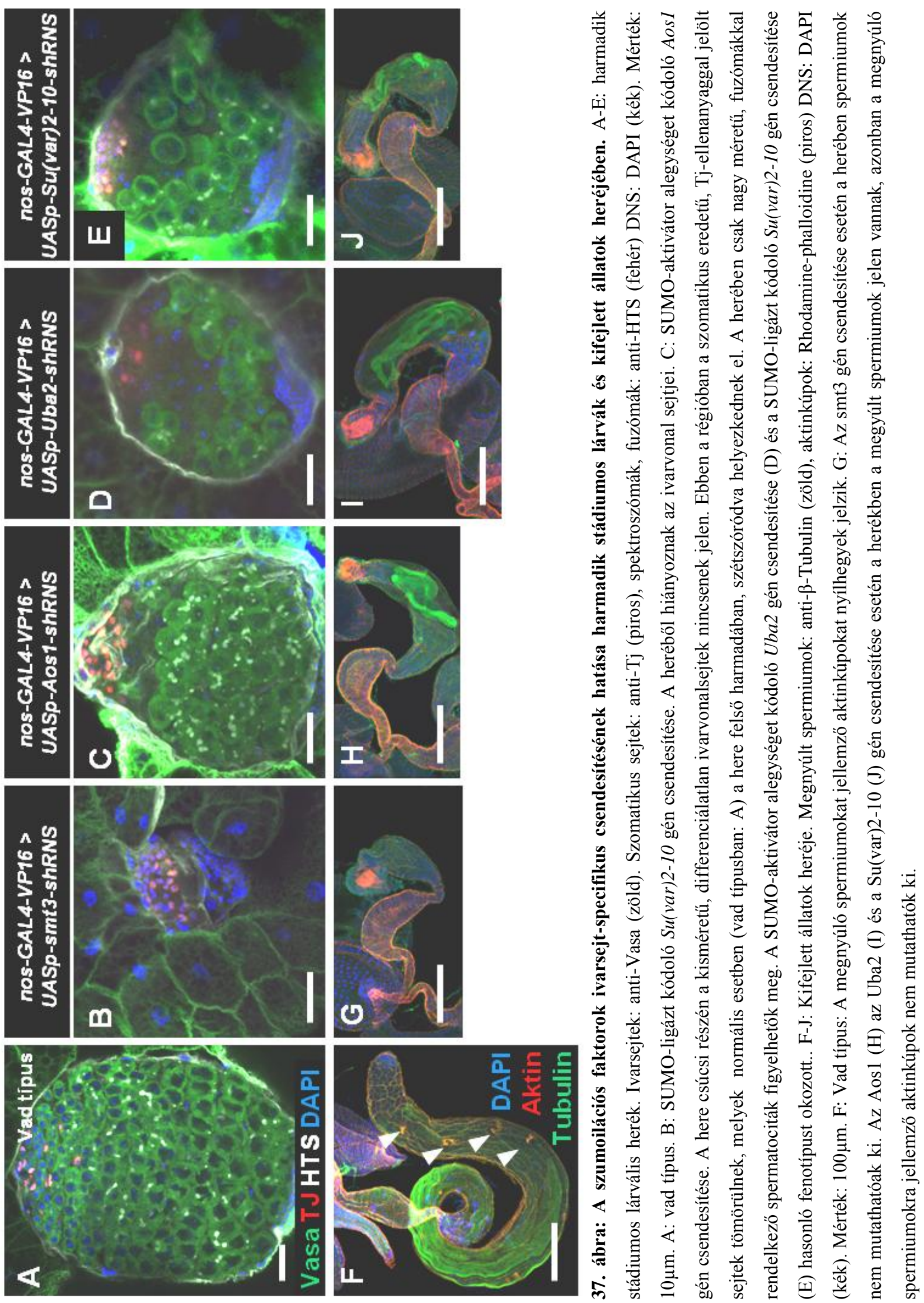


Eredményeink alapján arra következtettünk, hogy a szumoiláció a hím ivarszervekben elsősorban a csíravonal őssejtek fenntartásához szükséges, hiszen az Aos1, Uba2 és $S u(v a r) 2-10$ gének csendesítése során a lárvális herékből a csíravonal őssejtek eltűntek, ám a már differenciálódás útjára lépett ivarsejtek megmaradnak, sőt kifejlett állatokban is folytatják érésüket. Ezzel szemben a nőstény ivarvonalban a szumoiláció nem csak a csíravonal őssejtek fenntartásához, hanem azok differenciálódásához is szükséges. 


\section{Eredmények megvitatása}

\subsection{A Drosophila embrionális ivarsejt-fejlődés vizsgálata géncsendesítéssel}

Az ecetmuslicában az embrionális ivarsejtek az egyedfejlődés nagyon korai szakaszában, a cellularizáció során alakulnak ki az embrió poszterior pólusán. Lefüződésükkor a petefejlődés során képződő, anyai eredetű ivarplazmát öröklik citoplazmaként. Az ivarplazma olyan lokalizált mRNS molekulákat, fehérjéket tartalmaz, mely az embrionális ivarsejtek fejlődéséhez szükségesek. A testi sejtektől eltérően, a korai embrionális ivarsejtekben a zigotikus génkifejeződés az embrionális 8. stádiumig) inaktív. Eddig a fejlődési stádiumig tehát az ivarsejt-fejlődéséért kizárólag anyai hatású faktorok felelősek. A korai embrionális ivarsejtekben a zigotikus génexpresszió fokozatosan kapcsol be, ezért az anyai és a zigotikus kifejeződésű gének együtt irányítják az ivarvonal-fejlődés későbbi szakaszát [160,161]. Munkánk során a korai embriókba injektáltuk az embrionális ivarsejtekben kifejeződő gének elleni dsRNS-eket, így lehetővé vált ezen gének csendesítése függetlenül attól, hogy mRNS-ük anyai vagy zigotikus eredetü.

A génkifejeződési mintázatok adatbázisaiban összesen 502 olyan gént találtunk, melyeknek mRNS-e az embrionális fejlődés során ivarsejtekben, vagy ivarszervekben fejeződik ki, vagy ott feldúsulást mutat. A géncsendesítő kísérletsorozatunkban 48 gén csendesítése okozott reprodukálható ivarvonal-fejlődési rendellenességet embrionális korban vagy az egyedfejlődés későbbi szakaszában. A reprodukálható funkcióvesztéses fenotípussal azonosított 48 génekröl úgy gondoljuk, hogy biztosan szerepük van a Drosophila ivarvonal-fejlődésében. Kísérletsorozatunk során azonban feltehetőleg nem tudtuk kimutatni az összes gént, amely a vizsgált fejlődési folyamatban részt vesz. Egyrészt az ivarvonal transzkriptóma jóval több gén 
mRNS-ét tartalmazza, mint amit a génkifejeződési adatbázisok felsorolnak. Siddiqui és munkatársai kísérleteink elvégzése után közölték eredményeiket, melyek szerint a korai embriók ivarsejtjeiben több, mint 1700 gén mRNS-e dúsul fel testi sejtekhez képest [160]. A másik ok, amiért a pozitív találataink listája nem teljes, az lehet, hogy azok a gének melyeknek nem csak mRNS-e, hanem fehérjeterméke is anyai hatással kerül a petébe nem csendesíthetőek hatékonyan, hiszen az anyai fehérje menekíti a géncsendesítéssel előidézhető fenotípust. A jelenségre jó példa lehet a vasa (vas), az oskar (osk), a pumilio (pum) és piwi gén, melyek szerepe jól ismert az embrionális ivarsejtek kialakulásában és fenntartásában, azonban csendesítésükkel fenotípust nem tudtunk előidézni [162-165]. A harmadik lehetséges ok, ami miatt a vizsgált gének ivarsejtfunkcióját nem tudjuk kimutatni, a gének testi sejtekben megnyilvánuló pleiotróp hatása. A gének pleiotróp hatása miatt az embriók az ivarsejt-specifikus fenotípus azonosítása előtt elpusztulhatnak. Végül érdemes megemlíteni az injektált dsRNS hatékonyságára visszavezethető okokat. Elképzelhető, hogy az általunk használt, átlagosan $1 \mu \mathrm{g} / \mu 1$ koncentrációjú RNS oldat injektálása nem minden vizsgált gént volt képes hatékonyan csendesíteni. Magasabb koncentrációjú RNS-oldatokkal feltehetően növelhető lenne az azonosított gének száma [156]. Kísérleteink során azonban azt tapasztaltuk, hogy a magasabb koncentráció hatására a pleiotróp fenotípusok is megerősödnek, ami megnehezíti a fenotípus analízist. Az anyai fehérje jelenléte, a vizsgált gének pleiotróp hatása, valamint az alacsony dsRNS koncentráció miatt az RNSi kísérletsorozatban jelentős mértékü hamis negatív (fals negatív) eredményt kaphattunk, melynek mértékéről még közelítő becslést sem tudunk adni.

Kísérletsorozatunk erőssége inkább abban mutatkozik meg, hogy a 48 jelölt gén között nagyon kevés lehet a hamis (fals) pozitív találat. Az RNSi kísérletekben a fals pozitív eredményeknek fó oka a jól ismert off-target hatás. Az off-target hatásból eredő kísérleti hiba mértékét úgy minimalizáltuk, hogy a géncsendesítés elsőként 
azonosított pozitív jelöltjeire új géncsendesítő dsRNS-eket terveztünk, szintetizáltunk, és azokkal megismételtük a kísérleteket. Pozitív találatnak csak azokat a géneket tekintettük, melyeket mind a két alkalmazott dsRNS eredményesen csendesítette.

Az RNSi kísérletsorozat jelölt génjeinek mutáns alléljait érzékenyített genetikai háttéren vizsgáltuk (SOT rendszer). Az igazoló kísérlet célja az volt, hogy klasszikus allélok felhasználásával megerősítsük, hogy jelölt a gének valóban szükségesek az ivarsejt-fejlődéshez. A SOT rendszerrel történt igazoló kísérletben 32 jelölt gén esetében megerősítettük, azok az ivarsejtfejlődésben funkció tölthetnek be. A módszer lehetőséget adott az anyai hatású gének elkülönítésére. Az ivarsejthiányos fenotípus penetranciák alapján (>50\%) 14 génről gondoljuk, hogy anyai hatású módon járulnak hozzá az ivarsejt-fejlődéshez. Ez utóbbi eredmények jó egyezést mutattak a gének embrionális kifejeződési mintázataival.

\subsection{Az ivarsejt transzkriptóma funkcionális redundanciája alacsony szintű}

Kísérleteinkben az embrionális ivarsejtekben kifejeződő gének csupán 9,5\%ának csendesítése okozott ismételhető mutáns fenotípust az ivarsejt-fejlődés során. A fenotípussal rendelkező gének alacsony számára magyarázatot adhat a vizsgált gének közötti funkcionális redundancia is. Élesztő, és Caenorhabditis elegans modellszervezetekben kimutatták, hogy a paralóg és hasonló doménszerkezetü fehérjék képesek funkcionálisan helyettesíteni egymást, így biztosítva a fejlődés robosztusságát (tehát genetikai vagy környezeti változásokra adott rugalmas válaszát, fenotípusos stabilitását) [166-168]. Annak kimutatására, hogy a Drosophila embrionális ivarvonalban milyen mértékü a hasonló fehérjéken alapuló funkcionális redundancia, kettős géncsendesítési kísérletsorozatot hajtottunk végre. Vizsgálatainkban azon ivarsejtekben kifejeződő géneket vizsgáltuk kettős 
géncsendesítéssel, amelyek paralóg eredetűek, fehérjetermékük szekvencia szinten hasonlóságot mutat, vagy a fehérjék azonos domént tartalmaznak. Ily módon a 387 megvizsgált hasonló fehérjét kódoló génpárból mindössze egy pár, a trio és Gapl esetén tudtunk kimutatni genetikai kölcsönhatást, ami az ivarsejt transzkriptóma rendkívül csekély funkcionális redundanciájára utal.

A Rho és Ras, kis GTPázokat szabályozó RhoGEF fehérjét kódoló trio és a RasGAP kódoló Gapl gén együttes csendesítésének hatása túlmutatott az egyes géncsendesítések összeadódó hatásánál, a molekuláris funkciók figyelembevételével mégis úgy véljük, hogy a trio és Gapl funkció nem redundáns, mivel azok eltérő fehérjék aktivitásának szabályozásáért felelősek. A trio valószínüleg a dentritmorfogenezisben betöltött szerepéhez hasonlóan, a RhoA kis GTPáz aktivitását képes szabályozni, amely az embrionális ivarsejtek transzepiteliális vándorlásához szükséges [14,17,169]. A Gap1, a Ras1 kis GTPáz aktivitásának regulátora [170,171]. A Ras1-ről kimutatták, hogy az embrionális ivarsejtek korai osztódásához és vándorlásához szükséges [82]. Az ivarsejtekben betöltött funkciójukon túl e kis GTPázoknak fontos szerepük van az embrió morfogenezisében is [172-175]. Megfigyelésünk szerint a trio és Gap1 kis GTPáz regulátorok mennyiségének csökkentése önmagában nem okoz jelentős mértékü elváltozást az ivarsejt-fejlődés során, azonban e fehérjék együttes hiánya a folyamat összeomlását eredményezi.

Kettős RNSi kísérleteink során tehát funkcionális redundanciára utaló jelet nem találtunk. Mivel az ivarsejt transzkriptóma az általunk vizsgált 502 génnél nagyobb méretü, továbbá ebben az esetben sem tudjuk megjósolni a fals negatív eredmények előfordulási gyakoriságát, nem zárható ki, hogy funkcionális redundancia létezik hasonló fehérjék között, de eredményeink arra engednek következtetni, hogy ez igen alacsony mértékü lehet. Egy fejlődési folyamat robosztussága nem csupán redundáns fehérjék útján valósul meg, hanem genetikai hálózatok és miRNS-ek általi 
génszabályozás által is [176,177]. Véleményünk szerint a Drosophila ivarsejt-fejlődés robosztussága nem a hasonló fehérjéket kódoló gének közötti funkcionális átfedésen, hanem elsősorban a miRNS által valósulhat meg. Ez például úgy képzelhető el, hogy egy kieső génfunkció okozta káros hatás, a hibás funkciót helyettesítő, vagy a hiba káros hatását kompenzáló folyamatok aktiválódásával, megerősődésével áll helyre. Kimutatták, hogy a zebradánióhoz és Drosophilában is a miRNS-ek szerepet játszanak az ivarsejt vándorlás robosztusságának kialakításában [178,179].

\subsection{Az ivarvonal-specifikus géncsendesítés}

A géncsendesítő kísérletsorozatban fenotípust mutató génekre szekvenciaspecifikus, géncsendesítő shRNS-eket (mesterséges miRNS-eket) szereztünk be, amelyeket GAL4-forrás segítségével fejeztettünk ki a Drosophila ivarvonalban. Az elérhető ivarvonal-specifikus GAL4-források közül a nos-GAL4VP16 bizonyult a leghasználhatóbbnak, mivel a kifejlett állatok ivarvonalában végig erőteljes transzgén-kifejeződést biztosít. Kimutattuk, hogy az ivarvonal-fejlödés során a mesterséges miRNS-ek expressziója nem terheli túl a miRNS útvonalat, nem okoz aspecifikus fenotípusokat. Megmutattuk továbbá azt is, hogy az ivarvonal-specifikus géncsendesítés az embrionális ivarsejtekben nem müködik hatékonyan. Ezek alapján az ivarvonal-specifikus, shRNS alapú géncsendesítés nem helyettesítheti, de hatékonyan kiegészítheti a dsRNS-ek injektálásával történő vizsgálatainkat. Az injektált dsRNS-ek kiválóan alkalmasak az embrionális ivarsejt, vagy ivarszerv fenotípusok előidézésére, azonban a későbbi fenotípus-analízis korlátolt lehet a géncsendesítés pleiotróp hatása (pl. lárvális letalitás) vagy a dsRNS-ek lebomlása miatt. Ezzel szemben a transzgenikus shRNS alapú, ivarvonal-specifikus géncsendesítéssel a fejlődés későbbi stádiumaiban (lárvális és adult kor) vizsgálhatók 
a géntermékek hiányának következményei. Az ivarvonal-specifikus géncsendesítéssel bizonyítottuk, hogy a vizsgált gének szerepe az ivarvonal-fejlődésben ivarsejt-függő módon vagy legalábbis ivarsejt-függő módon is (pl. a pbl gén esetében) megvalósul. Különösen hasznosnak bizonyult a módszer azokban az esetekben, mikor az embrionális géncsendesítés kifejlett állatokban okozott ivarsejthiányos fenotípust, mert az ivarsejt-specifikus géncsendesítéssel egyszerübben és eredményesebben tudtuk vizsgálni a kifejlett állatok ivarszereveit.

A transzgenikus shRNS alapú géncsendesítések hatását elsősorban a kifejlett nőstények ivarszerveiben vizsgáltuk. A részletes fenotípus leírás a vizsgált gének többségénél teljesen új biológiai funkcióra világított rá. Néhány gén esetében pedig az irodalmi adatoknak megfelelő fenotípust kaptunk. A zpg gén csendesítése az ivarsejtek hiányát okozta az ivarszervekben, a zpg funkcióvesztéses mutánshoz hasonlóan [120]. A mei-P26 gén csendesítésénél a korábban leírt ivarsejt-tumorokat is megfigyeltünk [127,129,130]. Néhány gén esetében (nos, Tre1, dsx, spir) az ivarvonal-specifikus géncsendesítés nem, vagy csak kismértékben okozott fenotípust a GAL4-forrást és az UAS-shRNS-t hordozó állatok ivarsejtjeiben, ezek utódjaiban azonban nagymértékü ivarsejthiányos fenotípust figyeltünk meg. Ez azt jelenti, hogy az átíródott shRNS-ek anyai hatással öröklödnek és az utódokban is hatékonyan képesek müködni. Ezen gének embrionális ivarvonal-kialakulásban és -fejlődésben betöltött szerepe ismert, így ezek a fenotípusok a korábbi fenotípus leírásoknak megfeleltek [14,144-146].

Fontos megjegyezni a módszer kapcsán, hogy a pleiotróp hatású gének vizsgálata az ivarvonal-fejlődés késői szakaszában más módszerrel (ivarvonal-klónok használata) nehézkes vagy lehetetlen. Ennek oka egyrészt az, hogy a gének csak kis részének érhető el, megfelelően jellemzett funkcióvesztéses allélja, másrészt az, hogy az ivarvonal-klónok kialakításához idő- és munkaigényes rekombinációs technikát 
kell alkalmazni. Az ivarvonal-specifikus géncsendesítés további előnye, hogy különbözö, ivarvonalban müködő GAL4-források (ld. 4.5.2 fejezet), alkalmazásával a géncsendesítés térbeli kifejeződése finomítható, elősegítve ezzel a vizsgált gének biológiai funkciójának pontosabb megértését.

\subsection{A Drosophila ivarvonal-fejlődésében szerepet játszó gének evolúciós konzerváltsága}

A Drosophila gének evolúciós konzerváltságát jellemzi, hogy 45\%-uknak azonosították ortológját a humán genomban [180]. Az RNSi screen 48 jelöltjének evolúciós viszonyait megvizsgálva azt találtuk, hogy gének 72\%-nak ortológjai megtalálhatók gerincesekben. A jelölt gének kisebb része ízeltlábú-, rovar-, vagy gyümölcslégy- (Drosophilidae) specifikus. Ezen eredmények szerint a Drosophila ivarvonal-fejlődés faktorai nagymértékủ evolúciós konzerváltságot mutatnak, azonban a fejlődési folyamatnak vannak taxon-specifikus elemei is. Drosophilában az utóbbira a talán legismertebb példa az oskar (osk) gén, amely az ivarplazma és az embrionális ivarsejtek kialakulásáért felelős központi faktor, de csak a kétszárnyúak (Diptera) rendjére jellemző [7,181,182]. Az ivarsejtfejlődés szabályozásának fajok közötti hasonlóságát támasztja alá, hogy az általunk azonosított konzervált gének több mint harmadának mutatták ki funkcióját az ivarvonal-, vagy ivarszerv-fejlődésben más modellszervezetekben.

Kísérletsorozatunk jelöltjei között számos olyan gén is található, melyek funkcióját a Drosophila ivarsejt-fejlődésben korábban leírták. Például a nos gén csendesítése esetén, az irodalmi adatoknak megfelelően, az ivarsejt szám csökkenését, ivarszerv-kialakulás hibáit és hiányát figyeltük meg [78,144,183]. A pgc-dsRNS injektálása a nos-hoz hasonló fenotípusokat okozott. Érdekes, hogy az általunk 
megfigyelt fenotípusokat szintén géncsendesítéssel Nakamura és munkatársai is kimutatták, ráadásul jóval azelött, hogy a géncsendesítés módszere széles körben elterjedt volna a genetikai vizsgálatokban [71]. A Trel gén csendesítése az embrionális ivarsejtek középbélben való rekedését okozta, amely szintén egybevág a korábbi megfigyelésekkel [14]. Ezek a példák jól mutatják a géncsendesítési technikák létjogosultságát a Drosophila ivarsejt-fejlődés vizsgálatában.

Kísérleteink egyik legfontosabb eredménye kétségkívül az, hogy 29 olyan gént azonosítottunk, melynek szerepét eddig nem írták le az ivarvonal-fejlődés folyamatában. E gének nagy része (22/29) evolúciósan konzervált. Közülük ötnek (Bsg25D, CG14545, CG14838, CG17658, CG4281) sem molekuláris funkciója, sem biológiai szerepe nem ismert. Az ivarsejt-fejlődésben betöltött szerepét most először mutattuk be néhány olyan génnek, amelyek más fejlődési folyamatokból voltak ismertek. Ezekre példa az izomfejlődésben szerepet játszó myoblast city $(\mathrm{mbc})$, a stresszválaszban fontos hangover (hang), a kineziszerű fehérjéket kódoló Klp61F és Klp10A, vagy a de novo inozin-monofoszfát szintéziséért felelős adenozin 2 (ade2) gén. Ezen gének ivarsejtekben betöltött funkciójának további vizsgálatát megkönnyíthetik a már kifejlesztett, rendelkezésre álló eszközök (mutánsok, ellenanyagok, transzgenikus Drosophila vonalak).

\subsection{A pbl és a feo gén szerepe az ivarvonal-fejlödésben}

A pleiotróp hatású gének ivarsejt-fejlődésben betöltött szerepe technikai okok miatt nehezen vizsgálható. A géncsendesítés különböző erősségű fenotípusból álló sorozatok előállítását teszi lehetővé. A géntermékek részleges inaktiválása ivarsejt fenotípusokat idézhetnek elő, anélkül, hogy a testi sejtekben nagymértékü elváltozást, a vizsgált állat pusztulását okoznák. Ily módon két esszenciális gén funkcióját tudtuk 
kimutatni az ivarsejt-fejlődés különböző szakaszaiban. A pbl gén az embrionális sejtek citokinéziséhez szükséges, funkcióvesztéses alléljai a korábbi szakirodalmi adatok szerint a testi sejtek osztódási rendellenességeit, közvetve a testi sejtek vándorlásának hibáit, végül az embrió elpusztulását okozzák [149,152]. Kírérletsorozatunkban a $p b l$ gén csendesítése az embrionális ivarsejtek számának csökkenését, az ivarsejtek eltévedését, az embrionális gonádok összeszerelődésének hibáit, végső soron a gonádok hiányát okozta. Kimutattuk, hogy az a pbl mutáns embriókban az embrionális ivarszerv testi eredetü sejtjei is abnormális elhelyezkedésüek, ami arra utal, hogy az ivarszerv kialakulás hibái szomatikus fejlődési folyamatok, mint a mezoderma fejlődés hibáira is vezethetők vissza [151,152,184]. Az embrionális ivarsejtek számának csökkenése azonban a testi sejtek hibáival nehezen magyarázható. Ivarvonal-specifikus géncsendesítéssel kimutattuk, hogy a $p b l$ funkcióra az ivarsejt-fejlődés későbbi stádiumában is szükség van, és ez a funkció ivarsejt-függő. A kísérleti és irodalmi adatok alapján úgy véljük, hogy a $p b l$ ivarsejt-függő módon járul hozzá az ivarsejtek fenntartásához, valamint a szomatikus mezodermális sejtekben betöltött funkciója miatt, közvetett módon járul hozzá az ivarszerv-kezdemény kialakulásához.

A Feo a konzervált Ase1/PRC1 mikrotubulus keresztkötő fehérjék családjába tartozik [185]. Drosophila neuroblasztokban a Feo a mitotikus orsó középvonalában lokalizálódik, és az átfedő mikrotubulus plusz vég keresztkötésében vesz részt, ami a sikeres mitózishoz szükséges [148]. Kimutattuk, hogy a neuroblasztokhoz hasonlóan, a Feo a lárvális ivarsejtek mitoktikus orsójához is kötődik, és a mitotikus osztódást szabályozza. A $p b l$ génnel ellentétben, a feo inaktiválása során az embrionális ivarsejtek és ivarszervek fejlődése normálisnak bizonyult, ellenben a lárvák és kifejlett állatok ivarvonalsejtjei abnormálisan osztódtak. Mivel a feo funkcióvesztéses alléljai az ivarsejt fenotípus azonosíthatósága előtt az állatok pusztulását okozzák, 
géncsendesítési kísérletsorozatunk nélkül a gén ivarsejtekben betöltött szerepére valószínűleg nem derült volna fény.

\subsection{A mei-P26 az embrionális és lárvális ivarsejtek túléléséért felelős}

A Mei-P26 TRIM-NHL domént tartalmazó fehérje. Korábban, a kifejlett állatok ivarsejtjeiben betöltött többféle szerepét kimutatták: szerepet játszik GSC-k fenntartásában a mikroRNS-ek általi mRNS szabályozás által, de a cél RNS-ekhez közvetlenül kapcsolódva, azok transzlációjának gátlására is képes [128,129]. A meiP26 funkcióját kimutatták a nőstény ivarvonal cisztafejlődésében is [130]. Mivel a mei-P26 funkcióvesztéses mutációk hatása csak a kifejelett állatok ivarvonalában mutatható ki, ugyanakkor nőstény sterilitást okoznak, ezért a mei-P26 allélok használata alkalmatlan az anyai hatással öröklődő mRNS-ű mei-P26 gén korai ivarsejt-fejlődésben betöltött szerepének vizsgálatára. A mei-P26-dsRNS injektálása azonban lehetővé tette, hogy az embrionális és a lárvális ivarvonalban is megvizsgáljuk a fehérje hiányának hatását az ivarvonalban.

A mei-P26 gén csendesítése a nos mutánshoz hasonló ivarsejt-fenotípusokat okozott az embrionális fejlődés során: csökkent ivarsejtszámot, ivarsejt vándorlási hibákat, valamint a kifejlett állatokban ivarsejthiányos ivarszervek kialakulását eredményezte [95]. Kimutatták, hogy kifejlett állatokban a Mei-P26 transzlációs korepresszorként fizikai kölcsönhatást képes kialakítani a Nos fehérjével a csíravonal őssejtekben [128]. Más sejttípusokban azt találták, hogy a Nos fehérjekomplexet képez a Mei-P26-hoz hasonló TRIM-NHL fehérjével, a Brain tumor-ral (Brat), mellyel célgének mRNS-e - például a $C y c B$ mRNS-e - transzlációs represszoraként képesek viselkedni [186-188]. Embrionális ivarsejtekben a Brat nem szükséges a CycB Nos-függő transzlációs repressziójához [188]. Kadyrova és munkatársai 
feltételezése szerint az embrionális ivarsejtekben a CycB Nos-függő transzlációs repressziójához más ivarsejt-specifikus faktorra van szükség [189]. Kísérleteinkben kimutattuk, hogy a Mei-P26 hiányában az embrionális ivarsejtek száma csökken, és a vad típussal ellentétben a mei-P26-dsRNS-sel kezelt embriók ivarsejtjeiben a CycB fehérje kifejeződik. Modellünk szerint az embrionális ivarsejtekben a Mei-P26 a Nos fehérjével kölcsönhatva olyan mRNS-ek transzlációs repressziójában játszik szerepet, melyek biztosítják az ivarsejtek fenntartását, és megakadályozzák a szomatikus irányú differenciálódást.

A mei-P26 gén csendesítésének hatására a lárvális petefészkekben és herékben az ivarsejtek száma drasztikus mértékben lecsökken, sőt teljesen ivarsejthiányos ivarszervek is megfigyelhetök. Kifejlett, mei-P26 mutáns nöstények ivarvonalában kimutatták, hogy a csíravonal őssejtek nem tudnak fennmaradni, mert a fenntartásukhoz szükséges BMP útvonal nem aktiválódik bennük. Az aktív BMP jelátviteli út hiányában a csíravonal őssejtek cisztoblaszt, majd cisztasejt irányban differenciálódnak [128]. Kísérleteink során kimutattuk, hogy a mei-P26 deficiens lárvális ivarsejtekben, vad típushoz hasonlóan, a BMP útvonal aktív, és a cisztasejtekre jellemző spektroszóma nem mutatható ki bennük. Eredményeink arra utalnak, hogy a kifejlett nőstények csíravonal őssejtjeitől eltérően, a lárvális ivarsejtekben a mei-P26 funkciója nem abban nyilvánul meg, hogy a BMP jelátviteli út fenntartása által megóvja az őssejt jellegü ivarvonal sejteket a differenciálódástól. A mei-P26-ról kimutatták, hogy fejlődési állapottól és sejttípustól függően különböző célgének mRNS-ének transzlációját képes regulálni [128,130]. Elképzelhető, hogy a lárvális ivarszervekben a mei-P26 ezidáig ismeretlen célgének poszttranszkripciós szabályozásával járul hozzá az ivarvonalsejtek fenntartásához. 


\subsection{A szumoiláció szerepet játszik a csíravonal őssejtek fenntartásában és az ivarvonal differenciálódásában}

A szumoiláció konzervált posztranszlációs fehérjemódosító mechanizmus, mely a célfehérjék aktivitását, intracelluláris lokalizációját, stabilitását szabályozza [190]. Maga a SUMO fehérjét kódoló gén, az smt3, valamint a szumoilációs mechanizmusért felelős enzimeket kódoló Aos1, Uba2 és lwr gének mind az embrionális ivarvonalban, mind a kifejlett állatok ivarvonalában kifejeződnek [159].

dsRNS alapú géncsendesítési kísérletsorozatunk eredményeként kimutattuk, hogy a SUMO-aktivátor alegységet kódoló Aos1 és a SUMO-ligáz Su(var)2-10 géntermékek embrionális korban történő csendesítése kifejlett állatokban csökevényes ivarszervek kialakulását eredményezi. Habár a SUMO fehérjét kódoló smt3 és a másik SUMO-aktivátor alegységet kódoló Uba2, továbbá a SUMO-konjugáz lwr gént is kifejeződik az ivarvonalban, ivarsejt fenotípusokat nem figyelhettünk meg kifejlett állatokban, mert ezen gének csendesítése nagymértékü letalitást okozott. A shRNS-ek ivarvonalban történő kifejeztetésével azonban kimutattuk, hogy a SUMO fehérjét, valamint a szumoilációs enzimeket kódoló gének csendesítése ivarsejthiányos fenotípust okoz. Érdekes, hogy a SUMO eliminálása esetén a lárvális ivarszervek minden esetben ivarsejthiányosnak bizonyultak, míg az szumoilációs enzimeket kódoló gének csendesítésénél a lárvális ivarszervek mindig tartalmaztak ivarsejteket. Ennek az lehet a magyarázata, hogy a SUMO fehérje életideje jelentős mértékben rövidebb, mint a szumoilációs enzimeké. A szumoilációs enzimek hosszabb életidejüek, így az anyai hatású módon öröklött fehérjék sokáig képesek kompenzálni a shRNS-ek géncsendesítő hatását. Ennek megfelelően a lárvális nőstény ivarszervekben a szumoilációs enzimek csendesítése nem okozott jelentős mértékü csökkenést az ivarsejtek számában. Kifejlett állatok petefészkeiben már a 
szumoilációs enzimek hiányának hatására a petecsövek nagy része ivarsejthiányos fenotípust mutatott, mivel ekkorra feltehetőleg kimerült az anyai fehérjekészlet. Azon petecsövekben, melyekben kisszámú ivarsejt fennmaradt, az ivarvonal differenciálódására utaló jeleket nem tudtunk kimutatni, ami arra utal, hogy a nőstény ivarvonalban a szumoiláció nemcsak az ivarsejtek fenntartásához, hanem azok differenciálódásához is szükséges. Hímekben a szumoilációs gének csendesítése a lárvális here anterior csúcsán elhelyezkedő csíravonal őssejtek eltünését eredményezték, azonban többsejtes ciszták megfigyelhetőek voltak. Kifejlett állatokat megvizsgálva azt tapasztaltuk, hogy a csökevényesnek tűnő herében kisszámú, de jól fejlett spermatid van jelen, azonban a megnyúló spermatidokat, amelyek a spermiumfejlődés korábbi stádiumát képviselik, nem tudtudtuk kimutatni. Ez arra utal, hogy a szumoilációs enzimek hiányában a lárvális herében jelenlevő ciszták zavartalanul differenciálódnak, de a csíravonal össejtek hiánya miatt a differenciálódó ivarvonalsejtek utánpótlása megszakad. Kísérleteinkből ezért azt a következtetést vontuk le, hogy a szumoiláció a hím ivarvonalban a csíravonal őssejtek fenntartásához szükséges, a spermatoogóniumok, spermatociták és a spermatidok differenciálódásához azonban nem. Annak ellenére, hogy géncsendesített hímekben megnyúlt spermatidokat figyeltünk meg, a hímek sterilnek bizonyultak. Kearse és munkatársai kimutatták, hogy az smt3 gén ivarvonal-specifikus inaktiválása, zavart okoz egy riboszómális fehérje, az RpL22e szubcelluláris lokalizációjában meiotikus spermatidokban [191]. Bár ennek a fehérjének a hím ivarvonal-fejlödésében betöltött szerepe nem ismert, elképzelhető, hogy a sterilitás ennek tudható be. A sterilitás másik lehetséges magyarázata, hogy a csekély számú spermiumot tartalmazó heréből az érett spermiumok kiürülése ismeretlen okokból nem megy végbe.

A $S u(v a r) 2-10$ gént eredetileg a pozíció-effektus variegáció szupresszoraként azonosították [192]. Később kimutatták, hogy a gén a PIAS (protein inhibitor of 
activated STAT) konzervált fehérjecsaládba tartozik. A Su(var)2-10 gén valóban negatívan szabályozza a Jak/STAT szignáltranszdukciós útvonal STAT transzkripciós faktorát, amely számos fejlődési folyamathoz szükséges [193,194]. Azt is, kimutatták, hogy a PIAS fehérjék SUMO-ligáz aktivitással bírnak. Emlős és Drosophila sejtekben is szumoiláció útján valósul meg a STAT negatív regulációja [195,196]. A here csíravonal össejtjeiben a Jak/STAT szignáltranszdukciós útvonal aktív, és azok megújulásáért, fenntartásáért felelős [197,198]. Kondicionális mutáns allélokkal bizonyították, hogy a STAT hiányában a csíravonal őssejtek elpusztulnak [199]. Ezekkel a kísérleti eredményekkel nehezen összeegyeztethető, hogy egy STAT-et inaktiváló mechanizmus hiánya miért okozott kísérletsorozatunkban STAT mutánshoz hasonló fenotípust. Lehetséges magyarázat lenne, hogy a szumoiláció a hím ivarvonal őssejtjeiben a STAT finomszabályozásában játszik szerepet úgy, hogy gátolja annak túlmüködését. Azonban a STAT túlmüködés hatására nem a csíravonal őssejtek pusztulása, hanem azok túlszaporodása következik be [198]. Ezen okok miatt úgy véljük, hogy a szumoiláció szerepe hím csíravonal őssejtek fenntartásában STATfüggetlen módon valósul meg. Nöstény ivarvonal-fejlödésében is szerepet játszik a Jak/STAT jelátviteli útvonal, azonban itt nem a csírvonal össejtekben, hanem a közvetlen közelükben elhelyezkedő szomatikus kísérősejtek őssejtjeiben (escort stem cell, ESC) aktiválódik [200]. A kísérősejtek a germátrium struktúrájának normális kialakulásához, végső soron a csíravonal őssejtek fenntartásához szükségesek az ováriumban. A Jak/STAT útvonal müködését a kifejlett nőstények ivarvonalában nem mutatták ki. Mivel a nos-GAL4-VP16 driver ivarvonal-specifikus, ezért az ezzel kifejeztetett szumoilációs enzimek elleni shRNS-ek feltehetően nem hatnak a szomatikus kísérősejtek őssejtjeire [62]. A nőstényekben tapasztalt shRNS fenotípus alátámasztja a hímekben tapasztaltakat, miszerint a $S u(v a r) 2-10$ génnek a Jak/STAT útvonaltól független szerepe lehet az ivarsejtek életében. 


\section{Köszönetnyilvánítás}

Köszönetemet szeretném kifejezni elsősorban Dr. Erdélyi Miklósnak, aki ösztönző támogatásával, tanácsaival, építő kritikáival és türelemmel segítette e munkámat. Dolgozatom nem születhetett volna meg Dr. Jankovics Ferenc szakmai hozzájárulása nélkül, aki a bemutatott kísérletekben jelentős szerepet vállalt, különösen a gének (mei-P26, pbl, feo) részletes analízisében. Feri felkészültségével, alapos irodalmi és technikai ismereteivel nagyszerüen koordinálta a kísérleteket, ezért hálával tartozom neki. Köszönettel tartozom még Szathmári Margitnak, Velkeyné Krausz Ildikónak, Dr. Vilmos Péternek, Bujna Ágnesnek, Dr. Hegedűs Zoltánnak, akik munkájukkal hozzájárultak a bemutatott eredmények megszületéséhez. Köszönöm nekik, valamint csoportunk egykori és jelenlegi tagjainak, valamint a szegedi Drosophilás közösségnek, hogy a rám bízott feladatokat családias, baráti és nem utolsó sorban jó szakmai légkörben végezhettem. Köszönöm Dr. Török Tibornak és Dr. Honti Viktornak, hogy doktori dolgozatomat kijavították. Hasznos észrevételeiknek és javaslataiknak köszönhetően nyerte el dolgozatom végső formáját.

Végül szeretném megköszönni családom, elsősorban feleségem szerető támogatását és türelmét. 


\section{Irodalomjegyzék}

1. Ikenishi K (1998) Germ plasm in Caenorhabditis elegans, Drosophila and Xenopus. Dev Growth Differ 40: 1-10.

2. Extavour CG, Akam M (2003) Mechanisms of germ cell specification across the metazoans: epigenesis and preformation. Development 130: 5869-5884. doi:10.1242/dev.00804.

3. Gao M, Arkov AL (2013) Next generation organelles: structure and role of germ granules in the germline. Mol Reprod Dev 80: 610-623. doi:10.1002/mrd.22115.

4. Siomi MC, Sato K, Pezic D, Aravin AA (2011) PIWI-interacting small RNAs: the vanguard of genome defence. Nat Rev Mol Cell Biol 12: 246-258. doi:10.1038/nrm3089.

5. Lau NC (2010) Small RNAs in the animal gonad: guarding genomes and guiding development. Int J Biochem Cell Biol 42: 1334-1347. doi:10.1016/j.biocel.2010.03.005.

6. Cox RT, Spradling AC (2003) A Balbiani body and the fusome mediate mitochondrial inheritance during Drosophila oogenesis. Development 130: 1579-1590.

7. Lehmann R, Nüsslein-Volhard C (1986) Abdominal segmentation, pole cell formation, and embryonic polarity require the localized activity of oskar, a maternal gene in Drosophila. Cell 47: $141-152$.

8. Johnstone O, Lasko P (2001) Translational regulation and RNA localization in Drosophila oocytes and embryos. Annu Rev Genet 35: 365-406. doi:10.1146/annurev.genet.35.102401.090756.

9. Erdélyi M, Michon AM, Guichet A, Glotzer JB, Ephrussi A (1995) Requirement for Drosophila cytoplasmic tropomyosin in oskar mRNA localization. Nature 377: 524-527. doi:10.1038/377524a0.

10. Jankovics F, Sinka R, Lukácsovich T, Erdélyi M (2002) MOESIN crosslinks actin and cell membrane in Drosophila oocytes and is required for OSKAR anchoring. Curr Biol 12: 2060 2065.

11. Hay B, Jan LY, Jan YN (1988) A protein component of Drosophila polar granules is encoded by vasa and has extensive sequence similarity to ATP-dependent helicases. Cell 55: 577-587.

12. Zalokar M (1976) Autoradiographic study of protein and RNA formation during early development of Drosophila eggs. Dev Biol 49: 425-437.

13. Callaini G, Riparbelli MG, Dallai R (1995) Pole cell migration through the gut wall of the Drosophila embryo: analysis of cell interactions. Dev Biol 170: 365-375. doi:10.1006/dbio.1995.1222.

14. Kunwar PS, Starz-Gaiano M, Bainton RJ, Heberlein U, Lehmann R (2003) Tre1, a G proteincoupled receptor, directs transepithelial migration of Drosophila germ cells. PLoS Biol 1: E80. doi:10.1371/journal.pbio.0000080.

15. Zhang N, Zhang J, Cheng Y, Howard K (1996) Identification and genetic analysis of wunen, a gene guiding Drosophila melanogaster germ cell migration. Genetics 143: 1231-1241.

16. Starz-Gaiano M, Cho NK, Forbes A, Lehmann R (2001) Spatially restricted activity of a Drosophila lipid phosphatase guides migrating germ cells. Development 128: 983-991.

17. Kunwar PS, Sano H, Renault AD, Barbosa V, Fuse N, et al. (2008) Tre1 GPCR initiates germ cell transepithelial migration by regulating Drosophila melanogaster E-cadherin. J Cell Biol 183: 157-168. doi:10.1083/jcb.200807049. 
18. Campos-Ortega JA, Hartenstein V (2013) The Embryonic Development of Drosophila melanogaster. Berlin: Springer Berlin.

19. Van Doren M, Broihier HT, Moore LA, Lehmann R (1998) HMG-CoA reductase guides migrating primordial germ cells. Nature 396: 466-469. doi:10.1038/24871.

20. Hanyu-Nakamura K, Kobayashi S, Nakamura A (2004) Germ cell-autonomous Wunen2 is required for germline development in Drosophila embryos. Development 131: 4545-4553. doi:10.1242/dev.01321.

21. Casper AL, Van Doren M (2009) The establishment of sexual identity in the Drosophila germline. Development 136: 3821-3830. doi:10.1242/dev.042374.

22. Hinson S, Nagoshi RN (1999) Regulatory and functional interactions between the somatic sex regulatory gene transformer and the germline genes ovo and ovarian tumor. Development 126: $861-871$.

23. Waterbury JA, Horabin JI, Bopp D, Schedl P (2000) Sex determination in the Drosophila germline is dictated by the sexual identity of the surrounding soma. Genetics 155: 1741-1756.

24. Charlesworth B (2001) Genome analysis: More Drosophila Y chromosome genes. Curr Biol 11: R182-184.

25. Adám C, Henn L, Miskei M, Erdélyi M, Friedrich P, et al. (2010) Conservation of malespecific expression of novel phosphoprotein phosphatases in Drosophila. Dev Genes Evol 220: 123-128. doi:10.1007/s00427-010-0332-6.

26. Kawase E, Wong MD, Ding BC, Xie T (2004) Gbb/Bmp signaling is essential for maintaining germline stem cells and for repressing bam transcription in the Drosophila testis. Development 131: 1365-1375. doi:10.1242/dev.01025.

27. Bate M, Allan C. Spradling A (2009) The development of Drosophila melanogaster. Woodbury, N.Y.: Cold Spring Harbor Laboratory Press.

28. Li MA, Alls JD, Avancini RM, Koo K, Godt D (2003) The large Maf factor Traffic Jam controls gonad morphogenesis in Drosophila. Nat Cell Biol 5: 994-1000. doi:10.1038/ncb1058.

29. Deng W, Lin H (1997) Spectrosomes and fusomes anchor mitotic spindles during asymmetric germ cell divisions and facilitate the formation of a polarized microtubule array for oocyte specification in Drosophila. Dev Biol 189: 79-94. doi:10.1006/dbio.1997.8669.

30. Dan L. Lindsley, K. T. Tokuyasu (1980) The genetics and biology of drosophila 2d. 2d. London: Acad. Press.

31. Gilboa L, Lehmann R (2006) Soma-germline interactions coordinate homeostasis and growth in the Drosophila gonad. Nature 443: 97-100. doi:10.1038/nature05068.

32. Ashburner M (1980) The genetics and biology of drosophila. London: Academic Press.

33. Demerec M (1994) The biology of Drosophila. Facsim. ed. Plainview N.Y.: Cold Spring Harbor Laboratory Press.

34. Stephanou A (2009) JAK-STAT pathway in disease. Austin Tex.: Landes Bioscience.

35. Song X, Zhu C-H, Doan C, Xie T (2002) Germline stem cells anchored by adherens junctions in the Drosophila ovary niches. Science 296: 1855-1857. doi:10.1126/science.1069871.

36. Casanueva MO, Ferguson EL (2004) Germline stem cell number in the Drosophila ovary is regulated by redundant mechanisms that control Dpp signaling. Development 131: 1881-1890. doi:10.1242/dev.01076. 
37. Kirilly D, Wang S, Xie T (2011) Self-maintained escort cells form a germline stem cell differentiation niche. Development 138: 5087-5097. doi:10.1242/dev.067850.

38. Hudson AM, Petrella LN, Tanaka AJ, Cooley L (2008) Mononuclear muscle cells in Drosophila ovaries revealed by GFP protein traps. Dev Biol 314: 329-340. doi:10.1016/j.ydbio.2007.11.029.

39. Illmensee K, Mahowald AP (1974) Transplantation of posterior polar plasm in Drosophila. Induction of germ cells at the anterior pole of the egg. Proc Natl Acad Sci USA 71: 1016-1020.

40. Carpenter AT (1975) Electron microscopy of meiosis in Drosophila melanogaster females. I. Structure, arrangement, and temporal change of the synaptonemal complex in wild-type. Chromosoma 51: 157-182.

41. Lesch BJ, Page DC (2012) Genetics of germ cell development. Nature Reviews Genetics 13: 781-794. doi:10.1038/nrg3294.

42. Mahowald AP, Goralski TJ, Caulton JH (1983) In vitro activation of Drosophila eggs. Dev Biol 98: 437-445.

43. Grossniklaus U, Bellen HJ, Wilson C, Gehring WJ (1989) P-element-mediated enhancer detection applied to the study of oogenesis in Drosophila. Development 107: 189-200.

44. Orr WC, Galanopoulos VK, Romano CP, Kafatos FC (1989) A female sterile screen of the Drosophila melanogaster $\mathrm{X}$ chromosome using hybrid dysgenesis: identification and characterization of egg morphology mutants. Genetics 122: 847-858.

45. Underwood EM, Briot AS, Doll KZ, Ludwiczak RL, Otteson DC, et al. (1990) Genetics of 51D-52A, a region containing several maternal-effect genes and two maternal-specific transcripts in Drosophila. Genetics 126: 639-650.

46. Schmidt A, Palumbo G, Bozzetti MP, Tritto P, Pimpinelli S, et al. (1999) Genetic and molecular characterization of sting, a gene involved in crystal formation and meiotic drive in the male germ line of Drosophila melanogaster. Genetics 151: 749-760.

47. Mariol MC (1981) Genetic and developmental studies of a new grandchildless mutant of Drosophila melanogaster. Mol Gen Genet 181: 505-511.

48. Jankovics F, Sinka R, Erdélyi M (2001) An interaction type of genetic screen reveals a role of the Rab11 gene in oskar mRNA localization in the developing Drosophila melanogaster oocyte. Genetics 158: 1177-1188.

49. Vilmos P, Henn L, Szathmári M, Lukácsovich T, Sipos L, et al. (2007) Application of the dualtagging gene trap method combined with a novel automatic selection system to identify genes involved in germ cell development in Drosophila melanogaster. Acta Biol Hung 58 Suppl: 8194. doi:10.1556/ABiol.58.2007.Suppl.7.

50. Coffman CR, Strohm RC, Oakley FD, Yamada Y, Przychodzin D, et al. (2002) Identification of $\mathrm{X}$-linked genes required for migration and programmed cell death of Drosophila melanogaster germ cells. Genetics 162: 273-284.

51. Tomancak P, Berman BP, Beaton A, Weiszmann R, Kwan E, et al. (2007) Global analysis of patterns of gene expression during Drosophila embryogenesis. Genome Biol 8: R145. doi:10.1186/gb-2007-8-7-r145.

52. Lécuyer E, Yoshida H, Parthasarathy N, Alm C, Babak T, et al. (2007) Global analysis of mRNA localization reveals a prominent role in organizing cellular architecture and function. Cell 131: 174-187. doi:10.1016/j.cell.2007.08.003.

53. Ding D, Lipshitz HD (1993) A molecular screen for polar-localised maternal RNAs in the early embryo of Drosophila. Zygote 1: 257-271. 
54. Shigenobu S, Kitadate Y, Noda C, Kobayashi S (2006) Molecular characterization of embryonic gonads by gene expression profiling in Drosophila melanogaster. Proc Natl Acad Sci USA 103: 13728-13733. doi:10.1073/pnas.0603767103.

55. Szuperák M, Zvara A, Erdélyi M (2005) Identification of germ plasm-enriched mRNAs in Drosophila melanogaster by the cDNA microarray technique. Gene Expr Patterns 5: 717-723. doi:10.1016/j.modgep.2005.02.004.

56. Clemens JC, Worby CA, Simonson-Leff N, Muda M, Maehama T, et al. (2000) Use of doublestranded RNA interference in Drosophila cell lines to dissect signal transduction pathways. Proc Natl Acad Sci USA 97: 6499-6503. doi:10.1073/pnas.110149597.

57. Piccin A, Salameh A, Benna C, Sandrelli F, Mazzotta G, et al. (2001) Efficient and heritable functional knock-out of an adult phenotype in Drosophila using a GAL4-driven hairpin RNA incorporating a heterologous spacer. Nucleic Acids Res 29: E55-55.

58. Dietzl G, Chen D, Schnorrer F, Su K-C, Barinova Y, et al. (2007) A genome-wide transgenic RNAi library for conditional gene inactivation in Drosophila. Nature 448: 151-156. doi:10.1038/nature05954.

59. Handler D, Olivieri D, Novatchkova M, Gruber FS, Meixner K, et al. (2011) A systematic analysis of Drosophila TUDOR domain-containing proteins identifies Vreteno and the Tdrd12 family as essential primary piRNA pathway factors. EMBO J 30: 3977-3993. doi:10.1038/emboj.2011.308

60. Wang SH, Elgin SCR (2011) Drosophila Piwi functions downstream of piRNA production mediating a chromatin-based transposon silencing mechanism in female germ line. Proc Natl Acad Sci USA 108: 21164-21169. doi:10.1073/pnas.1107892109.

61. Haley B, Hendrix D, Trang V, Levine M (2008) A simplified miRNA-based gene silencing method for Drosophila melanogaster. Dev Biol 321: 482-490. doi:10.1016/j.ydbio.2008.06.015.

62. Rørth P (1998) Gal4 in the Drosophila female germline. Mech Dev 78: 113-118.

63. Ghildiyal M, Zamore PD (2009) Small silencing RNAs: an expanding universe. Nature Reviews Genetics 10: 94-108. doi:10.1038/nrg2504.

64. Misquitta L, Paterson BM (1999) Targeted disruption of gene function in Drosophila by RNA interference (RNA-i): a role for nautilus in embryonic somatic muscle formation. Proc Natl Acad Sci USA 96: 1451-1456.

65. Ivanov AI, Rovescalli AC, Pozzi P, Yoo S, Mozer B, et al. (2004) Genes required for Drosophila nervous system development identified by RNA interference. Proc Natl Acad Sci USA 101: 16216-16221. doi:10.1073/pnas.0407188101.

66. Naito Y, Yamada T, Matsumiya T, Ui-Tei K, Saigo K, et al. (2005) dsCheck: highly sensitive off-target search software for double-stranded RNA-mediated RNA interference. Nucleic Acids Res 33: W589-591. doi:10.1093/nar/gki419.

67. Rozen S, Skaletsky H (2000) Primer3 on the WWW for general users and for biologist programmers. Methods Mol Biol 132: 365-386.

68. Boutros M, Kiger AA, Armknecht S, Kerr K, Hild M, et al. (2004) Genome-wide RNAi analysis of growth and viability in Drosophila cells. Science 303: 832-835. doi:10.1126/science.1091266.

69. Saeed AI, Bhagabati NK, Braisted JC, Liang W, Sharov V, et al. (2006) TM4 microarray software suite. Meth Enzymol 411: 134-193. doi:10.1016/S0076-6879(06)11009-5. 
70. Ni J-Q, Zhou R, Czech B, Liu L-P, Holderbaum L, et al. (2011) A genome-scale shRNA resource for transgenic RNAi in Drosophila. Nat Methods 8: 405-407. doi: $10.1038 /$ nmeth. 1592 .

71. Nakamura A, Amikura R, Mukai M, Kobayashi S, Lasko PF (1996) Requirement for a noncoding RNA in Drosophila polar granules for germ cell establishment. Science 274: 20752079.

72. Jenkins AB, McCaffery JM, Van Doren M (2003) Drosophila E-cadherin is essential for proper germ cell-soma interaction during gonad morphogenesis. Development 130: 4417-4426.

73. Stein JA, Broihier HT, Moore LA, Lehmann R (2002) Slow as molasses is required for polarized membrane growth and germ cell migration in Drosophila. Development 129: 39253934.

74. Casper AL, Baxter K, Van Doren M (2011) no child left behind encodes a novel chromatin factor required for germline stem cell maintenance in males but not females. Development 138: 3357-3366. doi:10.1242/dev.067942.

75. Yang SY, Baxter EM, Van Doren M (2012) Phf7 controls male sex determination in the Drosophila germline. Dev Cell 22: 1041-1051. doi:10.1016/j.devcel.2012.04.013.

76. Ricardo S, Lehmann R (2009) An ABC transporter controls export of a Drosophila germ cell attractant. Science 323: 943-946. doi:10.1126/science.1166239.

77. Richardson BE, Lehmann R (2010) Mechanisms guiding primordial germ cell migration: strategies from different organisms. Nat Rev Mol Cell Biol 11: 37-49. doi:10.1038/nrm2815.

78. Hayashi Y, Hayashi M, Kobayashi S (2004) Nanos suppresses somatic cell fate in Drosophila germ line. Proc Natl Acad Sci USA 101: 10338-10342. doi:10.1073/pnas.0401647101.

79. Misquitta L, Wei Q, Paterson BM (2008) Injection of dsRNA into Drosophila Embryos for RNA Interference (RNAi). CSH Protoc 2008: pdb.prot4918.

80. Newsome TP, Schmidt S, Dietzl G, Keleman K, Asling B, et al. (2000) Trio combines with dock to regulate Pak activity during photoreceptor axon pathfinding in Drosophila. Cell 101: 283-294.

81. Gaul U, Mardon G, Rubin GM (1992) A putative Ras GTPase activating protein acts as a negative regulator of signaling by the Sevenless receptor tyrosine kinase. Cell 68: 1007-1019.

82. Li J, Xia F, Li WX (2003) Coactivation of STAT and Ras is required for germ cell proliferation and invasive migration in Drosophila. Dev Cell 5: 787-798.

83. Lilly MA, de Cuevas M, Spradling AC (2000) Cyclin A associates with the fusome during germline cyst formation in the Drosophila ovary. Dev Biol 218: 53-63. doi:10.1006/dbio.1999.9570.

84. Liu D, Matzuk MM, Sung WK, Guo Q, Wang P, et al. (1998) Cyclin A1 is required for meiosis in the male mouse. Nat Genet 20: 377-380. doi:10.1038/3855.

85. Wolgemuth DJ, Lele KM, Jobanputra V, Salazar G (2004) The A-type cyclins and the meiotic cell cycle in mammalian male germ cells. Int J Androl 27: 192-199. doi:10.1111/j.13652605.2004.00480.x.

86. Persson JL, Zhang Q, Wang XY, Ravnik SE, Muhlrad S, et al. (2005) Distinct roles for the mammalian A-type cyclins during oogenesis. Reproduction 130: 411-422. doi:10.1530/rep.1.00719.

87. Wang Z, Lin H (2005) The division of Drosophila germline stem cells and their precursors requires a specific cyclin. Curr Biol 15: 328-333. doi:10.1016/j.cub.2005.02.016. 
88. Van der Voet M, Lorson MA, Srinivasan DG, Bennett KL, van den Heuvel S (2009) C. elegans mitotic cyclins have distinct as well as overlapping functions in chromosome segregation. Cell Cycle 8: 4091-4102.

89. Kondo T, Yanagawa T, Yoshida N, Yamashita M (1997) Introduction of cyclin B induces activation of the maturation-promoting factor and breakdown of germinal vesicle in growing zebrafish oocytes unresponsive to the maturation-inducing hormone. Dev Biol 190: 142-152. doi:10.1006/dbio.1997.8673.

90. Polanski Z, Ledan E, Brunet S, Louvet S, Verlhac MH, et al. (1998) Cyclin synthesis controls the progression of meiotic maturation in mouse oocytes. Development 125: 4989-4997.

91. Shukla JN, Nagaraju J (2010) Doublesex: a conserved downstream gene controlled by diverse upstream regulators. J Genet 89: 341-356.

92. Kopp A (2012) Dmrt genes in the development and evolution of sexual dimorphism. Trends Genet 28: 175-184. doi:10.1016/j.tig.2012.02.002.

93. Kobayashi S, Yamada M, Asaoka M, Kitamura T (1996) Essential role of the posterior morphogen nanos for germline development in Drosophila. Nature 380: 708-711. doi:10.1038/380708a0.

94. Bhat KM (1999) The posterior determinant gene nanos is required for the maintenance of the adult germline stem cells during Drosophila oogenesis. Genetics 151: 1479-1492.

95. Forbes A, Lehmann R (1998) Nanos and Pumilio have critical roles in the development and function of Drosophila germline stem cells. Development 125: 679-690.

96. Köprunner M, Thisse C, Thisse B, Raz E (2001) A zebrafish nanos-related gene is essential for the development of primordial germ cells. Genes Dev 15: 2877-2885. doi:10.1101/gad.212401.

97. Tsuda M, Sasaoka Y, Kiso M, Abe K, Haraguchi S, et al. (2003) Conserved role of nanos proteins in germ cell development. Science 301: 1239-1241. doi:10.1126/science.1085222.

98. Julaton VTA, Reijo Pera RA (2011) NANOS3 function in human germ cell development. Hum Mol Genet 20: 2238-2250. doi:10.1093/hmg/ddr114.

99. Lai F, Singh A, King ML (2012) Xenopus Nanos1 is required to prevent endoderm gene expression and apoptosis in primordial germ cells. Development 139: 1476-1486. doi:10.1242/dev.079608.

100. Oliver B, Pauli D, Mahowald AP (1990) Genetic evidence that the ovo locus is involved in Drosophila germ line sex determination. Genetics 125: 535-550.

101. Mével-Ninio M, Terracol R, Kafatos FC (1991) The ovo gene of Drosophila encodes a zinc finger protein required for female germ line development. EMBO J 10: 2259-2266.

102. Dai X, Schonbaum C, Degenstein L, Bai W, Mahowald A, et al. (1998) The ovo gene required for cuticle formation and oogenesis in flies is involved in hair formation and spermatogenesis in mice. Genes Dev 12: 3452-3463.

103. Li B, Dai Q, Li L, Nair M, Mackay DR, et al. (2002) Ovol2, a mammalian homolog of Drosophila ovo: gene structure, chromosomal mapping, and aberrant expression in blind-sterile mice. Genomics 80: 319-325.

104. Giansanti MG, Farkas RM, Bonaccorsi S, Lindsley DL, Wakimoto BT, et al. (2004) Genetic dissection of meiotic cytokinesis in Drosophila males. Mol Biol Cell 15: 2509-2522. doi:10.1091/mbc.E03-08-0603. 
105. Elbaz J, Reizel Y, Nevo N, Galiani D, Dekel N (2010) Epithelial cell transforming protein 2 (ECT2) depletion blocks polar body extrusion and generates mouse oocytes containing two metaphase II spindles. Endocrinology 151: 755-765. doi:10.1210/en.2009-0830.

106. Abe K, Naruse C, Kato T, Nishiuchi T, Saitou M, et al. (2011) Loss of heterochromatin protein 1 gamma reduces the number of primordial germ cells via impaired cell cycle progression in mice. Biol Reprod 85: 1013-1024. doi:10.1095/biolreprod.111.091512.

107. Brown JP, Bullwinkel J, Baron-Lühr B, Billur M, Schneider P, et al. (2010) HP1gamma function is required for male germ cell survival and spermatogenesis. Epigenetics Chromatin 3: 9. doi:10.1186/1756-8935-3-9.

108. Chang JS, Tan L, Schedl P (1999) The Drosophila CPEB homolog, orb, is required for oskar protein expression in oocytes. Dev Biol 215: 91-106. doi:10.1006/dbio.1999.9444.

109. Castagnetti S, Ephrussi A (2003) Orb and a long poly(A) tail are required for efficient oskar translation at the posterior pole of the Drosophila oocyte. Development 130: 835-843.

110. Xu S, Hafer N, Agunwamba B, Schedl P (2012) The CPEB protein Orb2 has multiple functions during spermatogenesis in Drosophila melanogaster. PLoS Genet 8: e1003079. doi:10.1371/journal.pgen.1003079.

111. Hake LE, Richter JD (1994) CPEB is a specificity factor that mediates cytoplasmic polyadenylation during Xenopus oocyte maturation. Cell 79: 617-627.

112. Standart N, Minshall N (2008) Translational control in early development: CPEB, P-bodies and germinal granules. Biochem Soc Trans 36: 671-676. doi:10.1042/BST0360671.

113. Xiao J, Xu M, Li J, Chang Chan H, Lin M, et al. (2002) NYD-SP6, a novel gene potentially involved in regulating testicular development/spermatogenesis. Biochem Biophys Res Commun 291: 101-110. doi:10.1006/bbrc.2002.6396.

114. Johnstone O, Deuring R, Bock R, Linder P, Fuller MT, et al. (2005) Belle is a Drosophila DEAD-box protein required for viability and in the germ line. Dev Biol 277: 92-101. doi:10.1016/j.ydbio.2004.09.009.

115. Foresta C, Ferlin A, Moro E (2000) Deletion and expression analysis of AZFa genes on the human Y chromosome revealed a major role for DBY in male infertility. Hum Mol Genet 9: 1161-1169.

116. Ditton HJ, Zimmer J, Kamp C, Rajpert-De Meyts E, Vogt PH (2004) The AZFa gene DBY (DDX3Y) is widely transcribed but the protein is limited to the male germ cells by translation control. Hum Mol Genet 13: 2333-2341. doi:10.1093/hmg/ddh240.

117. Clark I, Giniger E, Ruohola-Baker H, Jan LY, Jan YN (1994) Transient posterior localization of a kinesin fusion protein reflects anteroposterior polarity of the Drosophila oocyte. Curr Biol 4: 289-300.

118. Pfender S, Kuznetsov V, Pleiser S, Kerkhoff E, Schuh M (2011) Spire-type actin nucleators cooperate with Formin-2 to drive asymmetric oocyte division. Curr Biol 21: 955-960. doi:10.1016/j.cub.2011.04.029.

119. Tazuke SI, Schulz C, Gilboa L, Fogarty M, Mahowald AP, et al. (2002) A germline-specific gap junction protein required for survival of differentiating early germ cells. Development 129: 2529-2539.

120. Gilboa L, Forbes A, Tazuke SI, Fuller MT, Lehmann R (2003) Germ line stem cell differentiation in Drosophila requires gap junctions and proceeds via an intermediate state. Development 130: 6625-6634. doi:10.1242/dev.00853. 
121. Whitten SJ, Miller MA (2007) The role of gap junctions in Caenorhabditis elegans oocyte maturation and fertilization. Dev Biol 301: 432-446. doi:10.1016/j.ydbio.2006.08.038.

122. Hime GR, Brill JA, Fuller MT (1996) Assembly of ring canals in the male germ line from structural components of the contractile ring. J Cell Sci 109 ( Pt 12): 2779-2788.

123. Goldbach P, Wong R, Beise N, Sarpal R, Trimble WS, et al. (2010) Stabilization of the actomyosin ring enables spermatocyte cytokinesis in Drosophila. Mol Biol Cell 21: 1482-1493. doi:10.1091/mbc.E09-08-0714.

124. Maddox AS, Habermann B, Desai A, Oegema K (2005) Distinct roles for two C. elegans anillins in the gonad and early embryo. Development 132: 2837-2848. doi:10.1242/dev.01828.

125. Deshpande G, Calhoun G, Schedl P (2004) Overlapping mechanisms function to establish transcriptional quiescence in the embryonic Drosophila germline. Development 131: 12471257. doi:10.1242/dev.01004.

126. Ward EJ, Shcherbata HR, Reynolds SH, Fischer KA, Hatfield SD, et al. (2006) Stem Cells Signal to the Niche through the Notch Pathway in the Drosophila Ovary. Current Biology 16: 2352-2358. doi:10.1016/j.cub.2006.10.022.

127. Page SL, McKim KS, Deneen B, Van Hook TL, Hawley RS (2000) Genetic studies of mei-P26 reveal a link between the processes that control germ cell proliferation in both sexes and those that control meiotic exchange in Drosophila. Genetics 155: 1757-1772.

128. Li Y, Maines JZ, Tastan OY, McKearin DM, Buszczak M (2012) Mei-P26 regulates the maintenance of ovarian germline stem cells by promoting BMP signaling. Development 139: 1547-1556. doi:10.1242/dev.077412.

129. Neumüller RA, Betschinger J, Fischer A, Bushati N, Poernbacher I, et al. (2008) Mei-P26 regulates microRNAs and cell growth in the Drosophila ovarian stem cell lineage. Nature 454: 241-245. doi:10.1038/nature07014.

130. Li Y, Zhang Q, Carreira-Rosario A, Maines JZ, McKearin DM, et al. (2013) Mei-p26 cooperates with Bam, Bgcn and Sxl to promote early germline development in the Drosophila ovary. PLoS ONE 8: e58301. doi:10.1371/journal.pone.0058301.

131. Clegg NJ, Frost DM, Larkin MK, Subrahmanyan L, Bryant Z, et al. (1997) maelstrom is required for an early step in the establishment of Drosophila oocyte polarity: posterior localization of grk mRNA. Development 124: 4661-4671.

132. Clegg NJ, Findley SD, Mahowald AP, Ruohola-Baker H (2001) Maelstrom is required to position the MTOC in stage 2-6 Drosophila oocytes. Dev Genes Evol 211: 44-48.

133. Pek JW, Lim AK, Kai T (2009) Drosophila maelstrom ensures proper germline stem cell lineage differentiation by repressing microRNA-7. Dev Cell 17: 417-424. doi:10.1016/j.devcel.2009.07.017

134. Van Doren M, Williamson AL, Lehmann R (1998) Regulation of zygotic gene expression in Drosophila primordial germ cells. Curr Biol 8: 243-246.

135. Telley IA, Gáspár I, Ephrussi A, Surrey T (2012) Aster migration determines the length scale of nuclear separation in the Drosophila syncytial embryo. J Cell Biol 197: 887-895. doi:10.1083/jcb.201204019.

136. Chen D, McKearin DM (2003) A discrete transcriptional silencer in the bam gene determines asymmetric division of the Drosophila germline stem cell. Development 130: 1159-1170.

137. Yagi R, Mayer F, Basler K (2010) Refined LexA transactivators and their use in combination with the Drosophila Gal4 system. Proc Natl Acad Sci USA 107: 16166-16171.

doi:10.1073/pnas.1005957107. 
138. Eun SH, Stoiber PM, Wright HJ, McMurdie KE, Choi CH, et al. (2013) MicroRNAs downregulate Bag of marbles to ensure proper terminal differentiation in the Drosophila male germline. Development 140: 23-30. doi:10.1242/dev.086397.

139. Iovino N, Pane A, Gaul U (2009) miR-184 has multiple roles in Drosophila female germline development. Dev Cell 17: 123-133. doi:10.1016/j.devcel.2009.06.008.

140. Shcherbata HR, Ward EJ, Fischer KA, Yu J-Y, Reynolds SH, et al. (2007) Stage-specific differences in the requirements for germline stem cell maintenance in the Drosophila ovary. Cell Stem Cell 1: 698-709. doi:10.1016/j.stem.2007.11.007.

141. Sano H, Renault AD, Lehmann R (2005) Control of lateral migration and germ cell elimination by the Drosophila melanogaster lipid phosphate phosphatases Wunen and Wunen 2. J Cell Biol 171: 675-683. doi:10.1083/jcb.200506038.

142. Verkhusha VV, Kuznetsova IM, Stepanenko OV, Zaraisky AG, Shavlovsky MM, et al. (2003) High stability of Discosoma DsRed as compared to Aequorea EGFP. Biochemistry 42: 78797884. doi:10.1021/bi034555t.

143. Insco ML, Bailey AS, Kim J, Olivares GH, Wapinski OL, et al. (2012) A self-limiting switch based on translational control regulates the transition from proliferation to differentiation in an adult stem cell lineage. Cell Stem Cell 11: 689-700. doi:10.1016/j.stem.2012.08.012.

144. Lehmann R, Nüsslein-Volhard C (1991) The maternal gene nanos has a central role in posterior pattern formation of the Drosophila embryo. Development 112: 679-691.

145. Manseau LJ, Schüpbach T (1989) cappuccino and spire: two unique maternal-effect loci required for both the anteroposterior and dorsoventral patterns of the Drosophila embryo. Genes Dev 3: 1437-1452.

146. Murray SM, Yang SY, Van Doren M (2010) Germ cell sex determination: a collaboration between soma and germline. Curr Opin Cell Biol 22: 722-729. doi:10.1016/j.ceb.2010.09.006.

147. Perrimon N, Engstrom L, Mahowald AP (1989) Zygotic lethals with specific maternal effect phenotypes in Drosophila melanogaster. I. Loci on the X chromosome. Genetics 121: 333-352.

148. Vernì F, Somma MP, Gunsalus KC, Bonaccorsi S, Belloni G, et al. (2004) Feo, the Drosophila homolog of PRC1, is required for central-spindle formation and cytokinesis. Curr Biol 14: 1569-1575. doi:10.1016/j.cub.2004.08.054.

149. Hime G, Saint R (1992) Zygotic expression of the pebble locus is required for cytokinesis during the postblastoderm mitoses of Drosophila. Development 114: 165-171.

150. Lehner CF (1992) The pebble gene is required for cytokinesis in Drosophila. J Cell Sci 103 ( Pt 4): 1021-1030.

151. Smallhorn M, Murray MJ, Saint R (2004) The epithelial-mesenchymal transition of the Drosophila mesoderm requires the Rho GTP exchange factor Pebble. Development 131: 26412651. doi:10.1242/dev.01150.

152. Schumacher S, Gryzik T, Tannebaum S, Müller H-AJ (2004) The RhoGEF Pebble is required for cell shape changes during cell migration triggered by the Drosophila FGF receptor Heartless. Development 131: 2631-2640. doi:10.1242/dev.01149.

153. Gregory SL, Lorensuhewa N, Saint R (2010) Signalling through the RhoGEF Pebble in Drosophila. IUBMB Life 62: 290-295. doi:10.1002/iub.310.

154. Prokopenko SN, Brumby A, O’Keefe L, Prior L, He Y, et al. (1999) A putative exchange factor for Rho1 GTPase is required for initiation of cytokinesis in Drosophila. Genes Dev 13: 23012314. 
155. Asaoka-Taguchi M, Yamada M, Nakamura A, Hanyu K, Kobayashi S (1999) Maternal Pumilio acts together with Nanos in germline development in Drosophila embryos. Nat Cell Biol 1: 431-437. doi:10.1038/15666.

156. Parrish JZ, Kim MD, Jan LY, Jan YN (2006) Genome-wide analyses identify transcription factors required for proper morphogenesis of Drosophila sensory neuron dendrites. Genes Dev 20: 820-835. doi:10.1101/gad.1391006.

157. Kanakousaki K, Gibson MC (2012) A differential requirement for SUMOylation in proliferating and non-proliferating cells during Drosophila development. Development 139: 2751-2762. doi:10.1242/dev.082974.

158. Talamillo A, Sánchez J, Barrio R (2008) Functional analysis of the SUMOylation pathway in Drosophila. Biochem Soc Trans 36: 868-873. doi:10.1042/BST0360868.

159. Hashiyama K, Shigenobu S, Kobayashi S (2009) Expression of genes involved in sumoylation in the Drosophila germline. Gene Expr Patterns 9: 50-53. doi:10.1016/j.gep.2008.08.001.

160. Siddiqui NU, Li X, Luo H, Karaiskakis A, Hou H, et al. (2012) Genome-wide analysis of the maternal-to-zygotic transition in Drosophila primordial germ cells. Genome Biol 13: R11. doi:10.1186/gb-2012-13-2-r11.

161. Simonelig M (2012) Maternal-to-zygotic transition: soma versus germline. Genome Biol 13: 145. doi:10.1186/gb-2012-13-2-145.

162. Lasko PF, Ashburner M (1990) Posterior localization of vasa protein correlates with, but is not sufficient for, pole cell development. Genes Dev 4: 905-921.

163. Lehmann R, Ephrussi A (1994) Germ plasm formation and germ cell determination in Drosophila. Ciba Found Symp 182: 282-296; discussion 296-300.

164. Barker DD, Wang C, Moore J, Dickinson LK, Lehmann R (1992) Pumilio is essential for function but not for distribution of the Drosophila abdominal determinant Nanos. Genes Dev 6 : 2312-2326.

165. Megosh HB, Cox DN, Campbell C, Lin H (2006) The role of PIWI and the miRNA machinery in Drosophila germline determination. Curr Biol 16: 1884-1894. doi:10.1016/j.cub.2006.08.051.

166. Conant GC, Wagner A (2004) Duplicate genes and robustness to transient gene knock-downs in Caenorhabditis elegans. Proc Biol Sci 271: 89-96. doi:10.1098/rspb.2003.2560.

167. $\mathrm{Gu} X(2003)$ Evolution of duplicate genes versus genetic robustness against null mutations. Trends Genet 19: 354-356. doi:10.1016/S0168-9525(03)00139-2.

168. Pasek S, Risler J-L, Brézellec P (2006) The role of domain redundancy in genetic robustness against null mutations. J Mol Biol 362: 184-191. doi:10.1016/j.jmb.2006.07.033.

169. Iyer SC, Wang D, Iyer EPR, Trunnell SA, Meduri R, et al. (2012) The RhoGEF trio functions in sculpting class specific dendrite morphogenesis in Drosophila sensory neurons. PLoS ONE 7: e33634. doi:10.1371/journal.pone.0033634.

170. Dickson B, Sprenger F, Morrison D, Hafen E (1992) Raf functions downstream of Ras1 in the Sevenless signal transduction pathway. Nature 360: 600-603. doi:10.1038/360600a0.

171. Boube M, Benassayag C, Seroude L, Cribbs DL (1997) Ras1-mediated modulation of Drosophila homeotic function in cell and segment identity. Genetics 146: 619-628.

172. Schöck F, Perrimon N (2002) Cellular processes associated with germ band retraction in Drosophila. Dev Biol 248: 29-39. 
173. Lu X, Chou TB, Williams NG, Roberts T, Perrimon N (1993) Control of cell fate determination by $\mathrm{p} 21 \mathrm{ras} / \mathrm{Ras} 1$, an essential component of torso signaling in Drosophila. Genes Dev 7: 621632.

174. Harden N, Ricos M, Ong YM, Chia W, Lim L (1999) Participation of small GTPases in dorsal closure of the Drosophila embryo: distinct roles for Rho subfamily proteins in epithelial morphogenesis. J Cell Sci 112 ( Pt 3): 273-284.

175. Bloor JW, Kiehart DP (2002) Drosophila RhoA regulates the cytoskeleton and cell-cell adhesion in the developing epidermis. Development 129: 3173-3183.

176. Kitano H (2004) Biological robustness. Nature Reviews Genetics 5: 826-837. doi:10.1038/nrg1471.

177. Hornstein E, Shomron N (2006) Canalization of development by microRNAs. Nature Genetics 38: S20-S24. doi:10.1038/ng1803.

178. Staton AA, Knaut H, Giraldez AJ (2011) miRNA regulation of Sdf1 chemokine signaling provides genetic robustness to germ cell migration. Nat Genet 43: 204-211. doi:10.1038/ng.758.

179. Kugler J-M, Chen Y-W, Weng R, Cohen SM (2013) Maternal loss of miRNAs leads to increased variance in primordial germ cell numbers in Drosophila melanogaster. G3 (Bethesda) 3: 1573-1576. doi:10.1534/g3.113.007591.

180. Ghosh A, Kling T, Snaidero N, Sampaio JL, Shevchenko A, et al. (2013) A global in vivo Drosophila RNAi screen identifies a key role of ceramide phosphoethanolamine for glial ensheathment of axons. PLoS Genet 9: e1003980. doi:10.1371/journal.pgen.1003980.

181. Ephrussi A, Lehmann R (1992) Induction of germ cell formation by oskar. Nature 358: $387-$ 392. doi:10.1038/358387a0.

182. Ephrussi A, Dickinson LK, Lehmann R (1991) Oskar organizes the germ plasm and directs localization of the posterior determinant nanos. Cell 66: 37-50.

183. Sato K, Hayashi Y, Ninomiya Y, Shigenobu S, Arita K, et al. (2007) Maternal Nanos represses hid/skl-dependent apoptosis to maintain the germ line in Drosophila embryos. Proc Natl Acad Sci USA 104: 7455-7460. doi:10.1073/pnas.0610052104.

184. Van Impel A, Schumacher S, Draga M, Herz H-M, Grosshans J, et al. (2009) Regulation of the Rac GTPase pathway by the multifunctional Rho GEF Pebble is essential for mesoderm migration in the Drosophila gastrula. Development 136: 813-822. doi:10.1242/dev.026203.

185. Duellberg C, Fourniol FJ, Maurer SP, Roostalu J, Surrey T (2013) End-binding proteins and Ase1/PRC1 define local functionality of structurally distinct parts of the microtubule cytoskeleton. Trends Cell Biol 23: 54-63. doi:10.1016/j.tcb.2012.10.003.

186. Muraro NI, Weston AJ, Gerber AP, Luschnig S, Moffat KG, et al. (2008) Pumilio binds para mRNA and requires Nanos and Brat to regulate sodium current in Drosophila motoneurons. J Neurosci 28: 2099-2109. doi:10.1523/JNEUROSCI.5092-07.2008.

187. Olesnicky EC, Bhogal B, Gavis ER (2012) Combinatorial use of translational co-factors for cell type-specific regulation during neuronal morphogenesis in Drosophila. Dev Biol 365: 208-218. doi:10.1016/j.ydbio.2012.02.028.

188. Sonoda J, Wharton RP (2001) Drosophila Brain Tumor is a translational repressor. Genes Dev 15: 762-773. doi:10.1101/gad.870801.

189. Kadyrova LY, Habara Y, Lee TH, Wharton RP (2007) Translational control of maternal Cyclin B mRNA by Nanos in the Drosophila germline. Development 134: 1519-1527.

doi:10.1242/dev.002212. 
190. Wilson VG, Rangasamy D (2001) Intracellular targeting of proteins by sumoylation. Exp Cell Res 271: 57-65. doi:10.1006/excr.2001.5366.

191. Kearse MG, Ireland JA, Prem SM, Chen AS, Ware VC (2013) RpL22e, but not RpL22e-likePA, is SUMOylated and localizes to the nucleoplasm of Drosophila meiotic spermatocytes. Nucleus 4: 241-258. doi:10.4161/nucl.25261.

192. Reuter G, Wolff I (1981) Isolation of dominant suppressor mutations for position-effect variegation in Drosophila melanogaster. Mol Gen Genet 182: 516-519.

193. Hari KL, Cook KR, Karpen GH (2001) The Drosophila Su(var)2-10 locus regulates chromosome structure and function and encodes a member of the PIAS protein family. Genes Dev 15: 1334-1348. doi:10.1101/gad.877901.

194. Betz A, Lampen N, Martinek S, Young MW, Darnell JE Jr (2001) A Drosophila PIAS homologue negatively regulates stat92E. Proc Natl Acad Sci USA 98: 9563-9568. doi:10.1073/pnas.171302098.

195. Ungureanu D, Vanhatupa S, Kotaja N, Yang J, Aittomaki S, et al. (2003) PIAS proteins promote SUMO-1 conjugation to STAT1. Blood 102: 3311-3313. doi:10.1182/blood-2002-123816.

196. Grönholm J, Ungureanu D, Vanhatupa S, Rämet M, Silvennoinen O (2010) Sumoylation of Drosophila transcription factor STAT92E. J Innate Immun 2: 618-624. doi:10.1159/000318676.

197. Tulina N, Matunis E (2001) Control of stem cell self-renewal in Drosophila spermatogenesis by JAK-STAT signaling. Science 294: 2546-2549. doi:10.1126/science.1066700.

198. Kiger AA, Jones DL, Schulz C, Rogers MB, Fuller MT (2001) Stem cell self-renewal specified by JAK-STAT activation in response to a support cell cue. Science 294: 2542-2545. doi:10.1126/science.1066707.

199. Brawley C, Matunis E (2004) Regeneration of male germline stem cells by spermatogonial dedifferentiation in vivo. Science 304: 1331-1334. doi:10.1126/science.1097676.

200. Decotto E, Spradling AC (2005) The Drosophila ovarian and testis stem cell niches: similar somatic stem cells and signals. Dev Cell 9: 501-510. doi:10.1016/j.devcel.2005.08.012. 


\section{Összefoglalás}

Az ecetmuslica (Drosophila melanogaster) az ivarvonal-fejlődés vizsgálatának elfogadott modellje. Az ivarvonalsejtek kialakulását, mely az egyedfejlődés nagyon korai szakaszában megy végbe, anyai hatású faktorok: mRNSek, fehérjék határozzák meg. A testi sejtektől eltérően, az embrió poszterior pólusán lefüződő ivarsejtekben a zigotikus transzkripció sokáig represszált, csak az embrionális gasztruláció idejétől aktiválódik fokozatosan. Az embrionális ivarvonalsejteknek a bélkezdemény falán történő átjutásához, a testüregben történő vándorlásához, az embrionális ivarszervek összerendeződéséhez anyai eredetű és zigotikus kifejeződési géntermékek egyaránt szükségesek.

Munkánk elsődleges célja az volt, hogy az embrionális ivarvonalsejtek kialakulásáért és fejlődéséért felelős géneket azonosítsuk, függetlenül attól, hogy azok géntermékei anyai vagy zigotikus eredetüek. Az eljárás első lépéseként génexpressziós adatbázisokból összegyüjtöttük azokat a géneket, melyek az embrionális ivarvonalsejtekben mRNS szinten kifejeződnek. Ezen 502 génnel géncsendesítő kísérletsorozatot hajtottunk végre, oly módon, hogy a génekre specifikus dsRNS-oldatot korai olyan Drosophila embriókba injektáltuk, melyek ivarsejtjei fluoreszcens fehérjét fejeztek ki. A fluoreszcens fehérjét kifejező ivarsejteket in vivo video-mikroszkópia segítségével követtük nyomon az embrionális fejlődés végéig. A videofelvételeket részletesen kielemeztük, a géncsendesítések által okozott ivarvonal-fejlődési rendellenességeket fenotípus kategóriákba soroltuk, és megállapítottuk, hogy az egyes gének csendesítései milyen gyakorisággal idéznek elő különböző fenotípusokat. Az embrionális fenotípus analízisen átesett állatokat felneveltük, majd a kifejlett állatok ivarszerveinek állapotát megvizsgálva meghatároztuk a csökevényes ivarszervek penetranciáját. Kísérleteink során 48 olyan 
gént azonosítottunk, amelyek csendesítése embrionális ivarsejt-fejlődési rendellenességeket okoz, vagy a kifejlett állatokban csökevényes ivarszervek megjelenését idézi elő. Ezen géncsendesítések hatása reprodukálható volt.

Géncsendesítő kísérletsorozatunk eredményeinek megerősítéseként a jelölt gének mutáns alléljait érzékenyített genetikai háttéren vizsgáltuk. Ebben a kísérletben a tesztelö Drosophila törzs három, az ivarsejt-kialakulásban szerepet játszó gén funkcióvesztéses allélját hordozza heterozigóta formában, amelyek anyai hatású, módon enyhe penetranciájú ivarsejthiányos ivarszerv fenotípust idéztek elő kifejlett állatokban. Kimutattuk, hogy a vizsgált gének több mint 70\%-ának alléljai jelentős mértékben megemelik az ivarsejthiányos fenotípus előfordulásának gyakoriságát az érzékenyített genetikai háttéren.

A géncsendesítő kísérletsorozat jelölt génjeinek evolúciós viszonyait vizsgálva azt találtuk, hogy a gének jelentős része erősen konzervált, 72\%-uknak kimutathatók ortológjaik gerinces állatokban. Közülük többről bizonyították már, hogy a Drosophila vagy más modellszervezet ivarvonal-fejlődésben szerepet játszanak. Kísérletsorozatunk egyik legjelentősebb eredményének azt tartjuk, hogy 29 olyan, többségében evolúciósan konzervált gént azonosítottunk, melyeknek e folyamatban korábban nem írták le funkcióját.

Kísérleteinkben az embrionális ivarsejtekben kifejeződő gének mintegy tizedének csendesítése okozott ismételhető mutáns fenotípust az ivarsejt-fejlődés során. A fenotípussal rendelkező gének alacsony arányára magyarázatot adhat a vizsgált gének közötti funkcionális redundancia. Más modellszervezetekben kimutatták, hogy a paralóg és hasonló doménszerkezetű fehérjék képesek funkcionálisan helyettesíteni egymást, így biztosítva a fejlődés robosztusságát. Annak eldöntésére, hogy a Drosophila embrionális ivarvonalban milyen mértékü a hasonló fehérjék funkcionális redundanciája, kettős géncsendesítési kísérletsorozatot 
hajtottunk végre, melynek során a hasonló fehérje szekvenciájú, az azonos doméneket hordozó fehérjéket kódoló és a paralóg géneket páronként, szimultán csendesítettük. Mindössze egyetlen génpár (trio és Gapl) esetében tudtunk kimutatni genetikai kölcsönhatást. Eredményeink alapján úgy véljük, hogy az ivarsejt transzkriptóma funkcionális redundanciája alacsony szintü.

A géncsendesítő kísérletsorozatunk során a célgénekre specifikus dsRNS-eket korai Drosophila embriókba injektáltuk. Mivel az injektált dsRNS-ek az ivarsejtekben és a testi sejtekben is hatékonyan müködnek, nem tudtuk kizárni, hogy a megfigyelt ivarsejt-fenotípusok a testi sejtek hibáinak következményei. Az ivarsejt-függő hatás bizonyítását miRNS útvonalon ható transzgenikus géncsendesítő short hairpin-RNSek ivarvonal-specifikus kifejeztetésével kívántuk elvégezni. Ugyan kimutattuk, hogy a módszer nem müködik hatékonyan az embrionális fejlődés alatt, azonban azt tapasztaltuk, hogy a csendesített gének nagy része ivarsejt-függő módon, de legalábbis ivarsejt-függő módon is hozzájárul az ivarvonal-fejlődéséhez. A transzgenikus géncsendesítő mesterséges miRNS-ek ivarsejt-specifikus kifejeztetésének hatása elsősorban lárvák és kifejlett állatok ivarszerveiben vizsgálható, ezért az eljárás jól kiegészítette az embriókon végzett géncsendesítési kísérletsorozatot, mely főként az embrionális ivarsejtek fejlődésének hibáinak kimutatására volt alkalmas.

A pleiotróp hatású gének szerepe az ivarvonal-fejlődésben nehezen vizsgálható. A géncsendesítési eljárás azonban lehetővé teszi olyan erősségű fenotípus-kondíciók előállítását, melyekben az ivarsejt hibái megfigyelhetők, azonban a testi sejtek elváltozásai kisebb mértékűek, mint a gén teljes funkcióvesztése esetén. Munkánk során több esszenciális, pleiotróp hatású gén ivarsejt-fejlődésben betöltött szerepét vizsgáltuk részletesebben. A RhoGEF fehérjét kódoló pebble ( $p b l$ ) gén csendesítése az embrionális ivarsejtek számának csökkenését, az ivarsejtek 
eltévedését, az embrionális gonádok összeszerelődésének hibáit, és ezen okok következményeként a gonádok hiányát okozta. Megfigyeltük, hogy a $p b l$ mutáns embriókban nemcsak az ivarvonal sejtjei, hanem az embrionális ivarszervek szomatikus komponensei is abnormális elhelyezkedésủek, jelezvén, hogy az embrionális fenotípus legalább részben a testi sejtek hibájának következménye. Ivarvonal-specifikus géncséndesítéssel azonban kimutattuk, hogy a $p b l$ ivarsejt-függő módon is hozzájárul az ivarsejtek fenntartásához. A mikrotubulus kötő fehérjét kódoló fascetto $(f e o)$ gén csendesítése esetén nem figyeltünk meg rendellenességeket az embrionális ivarsejtek fejlődése során. Lárvális ivarszervekben ellenben kevés számú, de rendellenesen nagyméretü ivarsejteket tudtunk kimutatni. Ezt a fenotípust mutáns allélok és ivarvonal-specifikus géncsendesítéssel is reprodukáltuk, utóbbi bizonyítja a feo ivarsejt-függő hatását. Vizsgálataink szerint a Feo fehérje az osztódó ivarsejtek telofázisa alatt az osztódási orsó középvonalában lokalizálódik. Eredményeink alapján elmondható, hogy a feo a lárvális ivarsejtek osztódásához szükséges.

A mei-P26 gén TRIM-NHL típusú cink-kötő fehérjét kódol. A génről korábban bizonyították, hogy összetett szerepe van a kifejlett nőstények ivarvonalában, azonban a korábbi egyedfejlődési stádiumokban ivarvonal-specifikus szerepét még nem írták le. Munkánk során kimutattuk, hogy a mei-P26 az embrionális és lárvális ivarsejt-fejlődés szabályozásában is szerepet játszik. A gén csendesítése az embrionális ivarsejtszám csökkenését eredményezi, mely feltehetőleg annak köszönhető, hogy a Mei-P26 hiányában az embrionális ivarsejtek szomatikus irányba differenciálódnak. Kimutattuk továbbá azt is, hogy a mei-P26 a lárvális ivarszervekben az őssejt jellegű ivarvonalsejtek fennmaradásához is szükséges.

A szumoiláció konzervált posztranszlációs fehérjemódosító mechanizmus, mely a célfehérjék aktivitását, intracelluláris lokalizációját, stabilitását szabályozza. Géncsendesítő kísérletsorozatunkban a szumoilációs emzimrendszer két tagját, a 
SUMO-aktivátor alegységet kódoló Aos1 és a SUMO-ligázt kódoló Supressor of variegation 2-10 (Su(var)2-10) gént azonosítottuk. Mindkét gén csendesítése csökevényes felnőttkori ivarszervek kialakulását eredményezte. Ivarvonal-specifikus géncsendesítéssel az említett géneken kívül megvizsgáltuk a SUMO aktivátor enzimkomplex másik tagját az Uba2, illetve a SUMO fehérjét kódoló smt3 gén hiányának hatását. Eredményeink szerint a szumoiláció a hím ivarvonalban a csíravonal őssejtek fenntartásához, míg nőstények esetében a csíravonal őssejtek fenntartásán túl, azok differenciálódásához is szükséges.

Eredményeinket összefoglásaként elmondható, hogy géncsendesítésen alapuló reverz genetikai kísérletsorozatot végrehajtva 48 ivarvonal-fejlődésben szerepet játszó gént azonosítottunk. Feltártuk e gének evolúciós viszonyait, és kimutattuk, hogy e gének csendesítése milyen rendellenességek okoz az egyedfejlődés különböző stádiumaiban. Bemutattuk, hogy az embrionális ivarsejt transzkriptóma redundanciája alacsony szintü. Részletesebb genetikai vizsgálatok segítségével leírtuk a $p b l$, a feo és a mei-P26 gének, továbbá a szumoiláció ivarvonal-fejlődésben betöltött szerepét. 


\section{Summary}

The fruit fly (Drosophila melanogaster) is an extensively used model organism for the research of germ cell development. The establishment of the germline takes place in a very early stage of embryogenesis and is governed by maternal factors such as mRNAs and proteins. The newly formed primordial germ cells (PGCs) at the posterior pole of the embryo are zygotically quiescent until gastrulation when zygotic transcription is progressively activated. PGCs require both maternally provided and zygotic factors for their transepithelial passage through the midgut wall, migration in the body cavity and coalescence with somatic cells to form the embryonic gonads.

The primary aim of our work was to identify factors required for germline formation and development regardless of their maternal or zygotic origin. To achieve this, we first screened publicly available databases for transcripts localized in the germline. Using this approach, 502 genes were selected, and their germline-dependent functions were analyzed by microinjecting gene-specific dsRNAs into syncytial embryos expressing a fluorescent protein in their germline. Fluorescently marked germ cells were monitored until the end of embryonic development using fluorescent time-lapse microscopy. Recorded movies were analyzed by visual inspection; the RNAi phenotypes were categorized and their penetrances were determined. As a secondary screen, the examined embryos were raised to adulthood, and their adult gonads were assayed for phenotypic defects. In this way, 48 genes displaying reproducible abnormal germ cell phenotypes at various stages of development were identified. 
To confirm the involvement of the newly identified genes in germ cell development, their loss-of-function alleles were tested for dominant genetic interactions with a sensitized genetic background. The sensitized line used in these genetic tests carries loss-of-function alleles of three genes known to be involved in germline establishment leading to a germ cell-deficient phenotype with low penetrance. We demonstrated that more than $70 \%$ of the genes we analyzed significantly enhanced the penetrance of the germ cell-less phenotype of the sensitized genetic background.

Analyzing the evolutionary conservation of our candidates, we found that $72 \%$ of the genes have orthologs in vertebrates, and several of them have been previously annotated with a function in gamete generation. One of the most important results of our work is the identification of 29 - mostly evolutionarily conserved - genes that have not been implicated in germ cell development yet.

In our experiments, when silenced, one tenth of the genes examined caused abnormal phenotypes in germline development in a reproducible way. This low rate of genes displaying RNAi phenotypes could be explained by a functional redundancy between similar proteins. In other organisms, paralogous proteins and proteins with similar domain structures have been demonstrated to substitute for each other thus ensuring the robustness of development. To determine the functional redundancy between similar proteins in the embryonic germline of Drosophila, we performed a large-scale combinatorial gene silencing experiment. We co-silenced the gene-pairs that are paralogs or encode proteins with similar amino acid sequences or domains. Only two genes (trio and Gapl) have been identified as showing genetic interaction with each other. Based on our results, we suggest that the redundancy of the germline transcriptome is low. 
In our RNAi experimental setup, we cannot discriminate between the PGCspecific and the somatic effects of the silenced genes. To examine whether our candidate genes act in a germline- or a soma-specific manner, we silenced them by expressing gene-specific shRNAs in the germline. Although we demonstrated that our approach is not efficient during embryonic development, we found that the majority of the genes silenced contributes to the development of the germ-line in a germlinespecific manner. The effect of germ-line specific expression of transgenic gene silencing artificial miRNAs can be studied primarily in larval and adult gonads, therefore, this technique supplements well the gene silencing experiments performed in the embryo.

The analysis of the role of pleiotropic genes in germline development is rather difficult, but the RNAi technique provides an ideal tool since it enables the generation of a series of phenotypes of different strength. Using this approach, we were able to detect genes essential for germline development. One of our identified essential genes is the RhoGEF protein encoding pebble $(p b l)$. Silencing of $p b l$ results in the decrease of PGC number, the loss of PGCs during migration, the abnormal compaction of the embryonic gonads and, as a result of these, the absence of gonads. These phenotypes were verified using loss-of-function $p b l$ alleles as well. We also demonstrate that it is not only the PGCs but also the somatic gonadal precursor cells (SGPs) that are in abnormal position in the $p b l$-silenced embryo. These results suggest that the $p b l$ phenotypes are caused, at least partially, by defects in somatic cells. Germlinespecific silencing of $p b l$ revealed its germline-dependent function in germ cell maintenance. The silencing of another essential gene, fascetto ( $f e o$ ), did not lead to abnormal phenotypes in embryonic stages, but in the larval gonads, the PGCs were abnormally large and low in number. This dsRNA-induced phenotype was verified with a loss-of-function allele and germline-specific silencing as well. When we 
examined Feo protein expression in larval germ cells, we found that the protein localizes to the midzone of the mitotic spindles. Based on these results, we suggest that Feo regulates the mitotic division of larval germ cells.

The mei-P26 gene encodes a zinc ion binding, TRIM-NHL domain-containing protein. Mei-P26 has been shown to be an essential regulator of germline development in adult Drosophila: it has a critical function in germline cyst differentiation, and it is also required for germline stem cell (GSC) self-renewal during oogenesis. We found that mei-P26 plays a role in germ cell development in earlier developmental stages as well. In Mei-P26-deficient embryos, the PGC number progressively decreases, and migrating PGCs express the $\mathrm{CycB}$ protein which is a marker of dividing somatic cells in this developmental stage. This result suggests that mei-P26 plays a role in the suppression of somatic cell fate in PGCs. We also demonstrated the requirement of mei-P26 in the larval germline, where it participates in PGC maintenance.

Sumoylation is a conserved posttranslational modification mechanism to alter the activity, localization, or stability of target proteins. In our RNAi screen, we identified the SUMO-activator subunit, Aos1, and the SUMO-ligase, Suppressor of variegation 2-10 (Su(var)2-10). Silencing of both genes induced the formation of vestigial adult gonads. To reveal the role of sumoylation in germline development, we performed germline-specific silencing of these genes and also that of Uba2, which encodes the other subunit of the SUMO-activator complex, and smt3, which encodes the SUMO protein. We found that sumoylation is essential for GSC maintenance in both sexes and for the differentiation of the germline in female gonads.

In summary, our screening strategy enabled the identification of 48 genes that play a role in germ cell development. We found pebble and fascetto to be essential for germ cell migration and germ cell division, respectively. Our data reveal a previously 
unanticipated role of mei-P26 in the maintenance of embryonic germ cell fate. We also demonstrated the requirement of sumoylation in GSC maintenance and differentiation. We performed systematic co-RNAi experiments in which we found a low rate of functional redundancy among homologous gene pairs. As our data indicate a high degree of evolutionary conservation in the genetic regulation of germ cell development, they are likely to provide valuable insights into the biology of the germline in general. 


\section{Függelék}

\begin{tabular}{|c|c|c|c|}
\hline Célgén & RNSi azonosító & Fw (5'-3') & $\operatorname{Rev}\left(5^{\prime}-3^{\prime}\right)$ \\
\hline ade2 & BKN22223 & GCCAAGGACTTTCCGATT & GTTGGCAGTGCAAAGAGC \\
\hline Aosl & BKN21990 & CCACACATCGGTGGCTAT & GCTGCTGGATGACAAGGA \\
\hline bel & BKN28143 & CACCAGACCCAACGGATA & CCCGAACATCACATCGTT \\
\hline$B s g 25 D$ & BKN31895 & TGTCTTGTGCGATGGTGA & CGGCAGCTGTTTGAGAAG \\
\hline casp & BKN28088 & ATGGACTCGCGTCTAGCA & GTTATGTGTGCCGCAGGT \\
\hline CG13298 & BKN22482 & GGTTGCGCTTGTTCATGT & TTGAGGCCAGACAGAGGA \\
\hline CG14438 & BKN23871 & AAATTGGCACGTCATTCG & TGAATCCAGCAGGTCCAC \\
\hline CG14545 & BKN31109 & CCATACATCATGCTGGTCAA & CGGAGCTTGGGCTATGTA \\
\hline CG14838 & BKN22699 & CGGACACCTCGTGTTTGT & ACGCCTCGAGAATTCCAT \\
\hline CG17658 & BKN24354 & GAAACGGAGTGGCAATCA & GAAACGGAGTGGCAATCA \\
\hline CG4281 & BKN26149 & GGTGCCATCTGCATTTGT & TCCAAACGTTTCCACAGC \\
\hline$C G 7271$ & BKN40421 & CAGAGTGCAGCATCACCA & GCGGAAGTGCTTCAGGTA \\
\hline$C G 8116$ & BKN32030 & GAAGCCGAAACACCTGCT & TAGATGAGGCTGGCGTTC \\
\hline$C G 9576$ & BKN22642 & CGCGCATAGGAGACATTC & CGTGGCGAAAAGAAATTG \\
\hline$c r q$ & BKN23364 & GCAAGACGAACGTCGATT & TGGCCATTAATTTGTCCAG \\
\hline CycA & BKN21599 & GAGGAAATCTATCCCCCAGA & CTTCAGCTTCTCAGGCATGT \\
\hline$C y c B$ & BKN22459 & CGATCTTCTGGAACTTGCTG & ACTTGCTCAATGGAAACCAC \\
\hline$d n c$ & BKN28541 & CTGCTCATGGAGGAGTTCTT & GCGGTATCATGCTCTGGTAG \\
\hline$d s x$ & BKN31266 & GTTTGCAGAGCCATCACC & CTGGAATAGCGACACGATG \\
\hline eIF5 & BKN22365 & TTCACCGCCAGAGTTGTT & TGTGAATGGATCGCATGA \\
\hline feo & BKN28553 & CGGCTTTCGTACAGATCG & GCGAAAAGATCCATGTGC \\
\hline hang & BKN26334 & AGGAGCAACAGCATGGAA & GTCCACTCCGTGCACATT \\
\hline Klp10A & BKN27588 & GGAATCGACTGGCTTTCC & GGGCAAGTGCATCACAGT \\
\hline Klp61F & BKN20600 & GCGTAGTGGCTGTTTTGC & GCATGATGGAGGTGGAGT \\
\hline knrl & BKN30585 & CAGCCGTTTCTCGAACTG & CACCCGCTCAACAAGAAG \\
\hline mael & BKN26194 & CAACCCGGAAAGCACATA & CGAATTAAACGCGAGTGC \\
\hline$m b c$ & BKN28072 & GGTTGGTGGGCAAATTCT & GAATTTGGTGTCGCCGTA \\
\hline mei-P26 & BKN26754 & ACGACAAGCTGATCATCCAT & TCGTGCTGTGACTGGAGTT \\
\hline Men & BKN27809 & AGGCACAGGTTGGCAATA & CGCTTTGGTCAAAACTGC \\
\hline$n c l b$ & BKN26312 & CAGTCTGGCCAACATCGT & TCATCCACTCGATGCACA \\
\hline neur & BKN27306 & GACGGGCAGTGAACACAT & CCCTGAATTCCCATCACC \\
\hline nos & BKN20023 & GTTGGCTCAGTCTGGAAAGA & GAGCAGCAAGTGGTAGTGGT \\
\hline orb & BKN22664 & GCACACCGCATATGGAAC & TTTTGTGCGATCCAGCTC \\
\hline ovo & BKN26285 & AGCTTCACCGCATATCCA & GCTTCGGCACGTGATAAT \\
\hline$p b l$ & BKN22310 & TGCCCACGTAGTTGGACT & ACAGATCGTCGGGATTCA \\
\hline$p g c$ & BKN30013 & ATGTGCGACTACCAGATGGA & CGGACTCAGGCTCAAGTTT \\
\hline Pglym 78 & BKN27771 & AAGACTTGGCGCCTGAA & AGTGTGCGTTCGATGGTC \\
\hline porin & BKN27645 & GTTCTTGCCATCGACCAG & AACGATGGCCAGGAGTTC \\
\hline Reph & BKN29935 & CACTGGCCTGGATATGGA & TGACGTTAGCGGCATTTC \\
\hline scra & BKN27556 & ATCAGCAATGCCAGCAAA & GGCTTGTCCGTGGTTATG \\
\hline $\operatorname{slg} A$ & BKN29194 & AAGGAGCAGCATCGGAGT & TGTGCTCGACCAGCTTCT \\
\hline spir & BKN29380 & AAGGACGCGAAGGAAGAC & GGCGAACTGGTGGATCA \\
\hline
\end{tabular}




\begin{tabular}{|l|l|l|l|}
\hline Célgén & RNSi azonosító & Fw (5'-3') & Rev (5'-3') \\
\hline Su(var)205 & BKN30828 & GGCATCGCATTGTACTTCA & TGGGCAAGAAAATCGACA \\
\hline Su(var)2-10 & BKN28790 & AACCGACCAAATGTGGAG & GGTTTTACGCCCTTCGTC \\
\hline SuUR & BKN26804 & AGATCGCTCGTGTTTGGA & TTTTGGTCGGTCCTGATG \\
\hline Thiolase & BKN29341 & ATACGTTGAAGGCGGATG & AGCCACCAACACCTACGA \\
\hline Tre1 & BKN22373 & CAGACATGCAGATGGATGAA & GGAGATGCTTAGCGAAATGA \\
\hline$z p g$ & BKN25026 & GCGGAAGTGGGTCTCTTT & CCCCGGAAAATCGTAACT \\
\hline
\end{tabular}

Függelék 1. táblázat: A Géncsendesítő kísérletsorozatban felhasznált dsRNS-ek azonosítói (Heidelberg2 RNAi gyüjtemény), illetve az új dsRNS-ek szintéziséhez felhasznált primerek génspecifikus szekvenciái. Csak a géncsendesítő kíséreletsorozat 48 jelölt génjére vonatkozó adatok vannak feltüntetve. 
UAS-shRNS-ek

\begin{tabular}{|c|c|c|c|}
\hline & Törzs & Genotípus & Célgén \\
\hline $\mathrm{B}$ & 36074 & $y^{l} s c^{*} v^{l} ; P\{T R i P . G L 00493\} a t t P 2$ & Aosl \\
\hline $\mathrm{B}$ & 35302 & $y^{l} s c^{*} v^{l} ; P\{$ TRiP.GL00205\}attP2 & bel \\
\hline $\mathrm{B}$ & 35185 & $y^{l} s c^{*} v^{l} ;$ P\{TRiP.GL00057\}attP2/TM3, Sb ${ }^{l}$ & bel \\
\hline $\mathrm{B}$ & 35625 & $y^{l} s c^{*} v^{l} ; P\{$ TRiP.GL00470\}attP2 & CG14545 \\
\hline $\mathrm{B}$ & 35661 & $y^{l} s c^{*} v^{l} ; P\{T R i P . G L V 21026\} a t t P 2$ & CG17658 \\
\hline $\mathrm{B}$ & 35685 & $y^{l} s c^{*} v^{l} ; P\{T R i P . G L V 21050\} a t t P 2$ & CG4281 \\
\hline $\mathrm{B}$ & 35807 & $y^{l} s c^{*} v^{l} ; P\{T R i P . G L 00455\} a t t P 2$ & $C G 9576$ \\
\hline $\mathrm{B}$ & 35694 & $y^{l} s c^{*} v^{l} ; P\{T R i P . G L V 21059\} a t t P 2$ & CycA \\
\hline $\mathrm{B}$ & 34544 & $y^{l} s c^{*} v^{l} ; P\{$ TRiP.HMSO1015\}attP2 & $C y c B$ \\
\hline $\mathrm{B}$ & 35645 & $y^{l} s c^{*} v^{l} ; P\{T R i P . G L V 21010\} a t t P 2$ & $d s x$ \\
\hline $\mathrm{B}$ & 34841 & $y^{l} s c^{*} v^{l} ; P\{$ TRiP.HMS00159\}attP2 & eIF5 \\
\hline $\mathrm{B}$ & 35467 & $y^{l} s c^{*} v^{l} ; P\{$ TRiP.GL00393\}attP2 & feo \\
\hline $\mathrm{B}$ & 35674 & $y^{l} s c^{*} v^{l} ; P\{T R i P . G L V 21039\} a t t P 2$ & hang \\
\hline B & 33963 & $y^{l} s c^{*} v^{l} ;$ P\{TRiP.HMS00920\}attP2 & Klp10A \\
\hline $\mathrm{B}$ & 33685 & $y^{l}$ sc $^{*} v^{l} ;$ P\{TRiP.HMSO0552\}attP2/TM3, Sb ${ }^{l}$ & Klp61F \\
\hline $\mathrm{B}$ & 35804 & $y^{l} s c^{*} v^{I} ; P\{$ TRiP.GL00441\}attP40 & Klp61F \\
\hline $\mathrm{B}$ & 34793 & $y^{l} s c^{*} v^{l} ; P\{$ TRiP.HMSO0102\}attP2 & mael \\
\hline $\mathrm{B}$ & 33722 & $y^{l} s c^{*} v^{l} ; P\{$ TRiP.HMS00604\}attP2 & $m b c$ \\
\hline $\mathrm{B}$ & 32355 & $y^{l} s c^{*} v^{l} ; P\{T R i P . H M S 00346\} a t t P 2$ & $m b c$ \\
\hline $\mathrm{B}$ & 35412 & $y^{l} s c^{*} v^{l} ; P\{$ TRiP.GLO0334\}attP2 & neur \\
\hline $\mathrm{B}$ & 32985 & $y^{l}$ sc $^{*} v^{l} ;$ P\{TRiP.HMS00785\}attP2 & nos \\
\hline $\mathrm{B}$ & 33973 & $y^{l} s c^{*} v^{l} ;$ P\{TRiP.HMS00930\}attP2 & nos \\
\hline B & 35413 & $y^{l} s c^{*} v^{l} ; P\{T R i P . G L 00335\} a t t P 2 / T M 3, S b^{l}$ & ovo \\
\hline $\mathrm{B}$ & 33720 & $y^{l} s c^{*} v^{l} ; P\{$ TRiP.HMSO0601\}attP2 & $p g c$ \\
\hline $\mathrm{B}$ & 32386 & $y^{l} s c^{*} v^{l} ; P\{$ TRiP.HMS00378\}attP2 & $p g c$ \\
\hline $\mathrm{B}$ & 33400 & $y^{l} s c^{*} v^{l} ; P\{$ TRiP.HMSO0278\}attP2 & Su(var)205 \\
\hline $\mathrm{B}$ & 32915 & $y^{l} s^{*} v^{l} ;$; P\{RiP.HMS00705\}attP2/TM3, Sb ${ }^{l}$ & Su(var)2-10 \\
\hline B & 32956 & $y^{l}$ sc $^{*} v^{I} ;$ P $\{$ TRiP.HMSO0750\}attP2 & $\mathrm{Su}($ var $) 2-10$ \\
\hline $\mathrm{B}$ & 35681 & $y^{l} s c^{*} v^{l} ; P\{$ TRiP.GLV21046\}attP2 & term \\
\hline $\mathrm{B}$ & 34546 & $y^{l}$ sc $^{*} v^{l} ;$ P\{TRiP.HMSO1017\}attP2 & Thiolase \\
\hline B & 33718 & $y^{l}$ sc $^{*} v^{I} ;$ P $\left\{\right.$ TRiP.HMSO0599\}attP2/TM3, Sb ${ }^{l}$ & Tre1 \\
\hline $\mathrm{B}$ & 34956 & $y^{l}$ Sc $^{*} v^{l} ;$ P\{TRiP.HMSO0433\}attP2 & Tre1 \\
\hline $\mathrm{B}$ & 35607 & $y^{l} s c^{*} v^{l} ; P\{$ TRiP.GL00447\}attP2 & $z p g$ \\
\hline $\mathrm{B}$ & 36686 & $y^{l} s c^{*} v^{l} ; P\{$ TRiP.HMSO1574\}attP2 & ade2 \\
\hline $\mathrm{B}$ & 36828 & $y^{l} s c^{*} v^{l} ; P\{$ TRiP.GL01064\}attP2 & $B s g 25 D$ \\
\hline $\mathrm{B}$ & 36813 & $y^{l} s c^{*} v^{l} ; P\{$ TRiP.GL01031\}attP2 & CG6543 \\
\hline $\mathrm{B}$ & 36837 & $y^{l} s c^{*} v^{l} ; P\{$ TRiP.GL01078\}attP2 & CG8116 \\
\hline $\mathrm{B}$ & 36619 & $y^{l} s c^{*} v^{l} ; P\{$ TRiP.GL00579\}attP2 & CG13298 \\
\hline $\mathrm{B}$ & 38957 & $y^{l} v^{l} ;$ P $\{$ TRiP.HMSO1871\}attP2 & $C y c B$ \\
\hline $\mathrm{B}$ & 38979 & $y^{l} s c^{*} v^{l} ; P\{$ TRiP.HMSO1895\}attP2 & $C y c B$ \\
\hline B & 38981 & $y^{l} s c^{*} v^{l} ;$ P\{TRiP.HMS01897\}attP2 & $C y c B$ \\
\hline
\end{tabular}




\begin{tabular}{|c|c|c|c|}
\hline & Törzs & Genotípus & Célgén \\
\hline $\mathrm{B}$ & 39024 & $y^{l} s c^{*} v^{l} ;$ P\{TRiP.HMSO1943\}attP2 & $C y c B$ \\
\hline $\mathrm{B}$ & 36664 & $y^{l} s c^{*} v^{l} ;$ P\{TRiP.HMSO1552\}attP2 & knrl \\
\hline $\mathrm{B}$ & 35202 & $y^{l} s c^{*} v^{l} ; P\{T R i P . G L 00077\} a t t P 2$ & mael \\
\hline $\mathrm{B}$ & 38256 & $y^{l} s c^{*} v^{l} ;$ P\{TRiP.HMSO1700\}attP40 & Men \\
\hline $\mathrm{B}$ & 36792 & $y^{l} s c^{*} v^{l} ;$ P\{TRiP.GLO0531\}attP40 & Su(var)205 \\
\hline $\mathrm{B}$ & 36893 & $y^{l} s c^{*} v^{l} ;$ P\{TRiP.GL01080\}attP2 & SuUR \\
\hline $\mathrm{B}$ & 36855 & $y^{l} s c^{*} v^{l} ;$ P\{TRiP.GL01124\}attP40 & $m e i-P 26$ \\
\hline $\mathrm{B}$ & 36841 & $y^{l} s c^{*} v^{l} ;$ P\{TRiP.GL01092\}attP2 & $p b l$ \\
\hline $\mathrm{B}$ & 28343 & $y^{l} v^{l} ; P\{$ TRiP.JF02979\}attP2 & $p b l$ \\
\hline $\mathrm{B}$ & 38925 & $y^{I} s^{*} v^{l} ; P\{$ TRiP.GL01014\}attP40/CyO & Trel \\
\hline $\mathrm{B}$ & 41652 & $y^{l} v^{l} ; P\{$ TRiP.GL01234\}attP2 & Men \\
\hline B & 41826 & $y^{l} v^{I} ; P\{$ TRiP.GL01254\}attP2 & $n c l b$ \\
\hline $\mathrm{B}$ & 40831 & $y^{l} v^{l} ;$ P\{TRiP.HMSO1997\}attP40 & $c r q$ \\
\hline $\mathrm{B}$ & 41644 & $y^{l} v^{l} ;$ P\{TRiP.GL01226\}attP2/TM3, Sb ${ }^{l}$ & $d n c$ \\
\hline $\mathrm{B}$ & 41845 & $y^{l} v^{l} ; P\{$ TRiP.GL01273\}attP2 & $F s(2) K e t$ \\
\hline B & 41841 & $y^{l} v^{l} ;$ P\{TRiP.GL01269\}attP2/TM3, Sb ${ }^{l}$ & scra \\
\hline $\mathrm{B}$ & 41890 & $y^{l}$ sc $^{*} v^{l} ;$ P $\{$ TRiP.GL01302\}attP40 & CG4281 \\
\hline $\mathrm{B}$ & 42627 & $y^{l} v^{l} ;$ P\{TRiP.HMSO2462\}attP40 & ovo \\
\hline $\mathrm{B}$ & 41822 & $y^{l} v^{l} ; P\{$ TRiP.GL01250\}attP2 & CG7271 \\
\hline $\mathrm{B}$ & 41870 & $y^{l} s^{*} v^{l} ;$; P\{TRiP.GL01300\}attP40 & hang \\
\hline $\mathrm{B}$ & 41864 & $y^{I}$ sc $^{*} v^{l} ;$ P $\{$ TRiP.GL01294\}attP40 & $d s x$ \\
\hline $\mathrm{B}$ & 41603 & $y^{1} v^{l} ; P\{$ TRiP.GL01143\}attP2 & Pglym 78 \\
\hline $\mathrm{B}$ & 41658 & $y^{l} v^{l} ; P\{$ TRiP.GL01240\}attP2 & Reph \\
\hline $\mathrm{B}$ & 42921 & $y^{l} s c^{*} v^{l} ;$ P\{TRiP.HMSO2614\}attP40 & term \\
\hline B & 40831 & $y^{l} v^{l} ;$ P\{TRiP.HMSO1997\}attP40 & $c r q$ \\
\hline $\mathrm{B}$ & 44424 & $y^{l} v^{l} ;$ P\{TRiP.GLC01361\}attP40 & $m b c$ \\
\hline $\mathrm{B}$ & 43161 & $y^{l} v^{l} ; P\{$ TRiP.GL01503\}attP2 & spir \\
\hline $\mathrm{B}$ & 43143 & $y^{l} v^{l} ; P\{$ TRiP.GL01484\}attP2 & orb \\
\hline $\mathrm{B}$ & 42873 & $y^{l} s c^{*} v^{l} ; P\{$ TRiP.HMSO2566\}attP40 & CG13298 \\
\hline $\mathrm{B}$ & 41845 & $y^{l} v^{l} ; P\{$ TRiP.GL01273\}attP2 & $F s(2) K e t$ \\
\hline $\mathrm{B}$ & 35782 & $y^{l} s c^{*} v^{l} ; P\{$ VALIUM20-EGFP\}attP2 & $e G F P$ \\
\hline- & - & $y^{l} s c^{*} v^{l} ; P\{$ VALIUM22-EGFP\}attP2 & $e G F P$ \\
\hline
\end{tabular}

Meghajtó elemek

\begin{tabular}{|l|r|l|}
\hline & \multicolumn{1}{|l|}{ Törzs } & Genotípus \\
\hline B & 4937 & $w^{1118} ;$ P\{GAL4::VP16-nos.UTR $\} C G 6325^{M V D 1}$ \\
\hline B & 44242 & $w^{1118} ;$ P\{osk-GAL4::VP16\}F/TM3, Sb \\
\hline B & 4442 & $y^{1} w^{1} ;$ P $\{$ GAL4-nos.NGT $\} 40$ \\
\hline- & - & $w^{1118} ;$ P $\{$ bam-GAL4:VP16\} \\
\hline
\end{tabular}


Mutáns allélek

\begin{tabular}{|c|c|c|c|}
\hline & Törzs & Genotípus & Érintett gén \\
\hline $\mathrm{B}$ & 8722 & $w^{*} ;$ spir $^{I 83} / \mathrm{CyO} ; \mathrm{Sb}^{l} / \mathrm{TM} 3, \mathrm{Ser}^{l}$ & spir \\
\hline $\mathrm{B}$ & 11331 & $P\{P Z\}_{s c r a}{ }^{03427}, \mathrm{cn}^{1} / \mathrm{CyO} ; \mathrm{ry}{ }^{506}$ & scra \\
\hline $\mathrm{Sz}$ & $\begin{array}{l}\text { CB-0909- } \\
3\end{array}$ & $w^{1118} ; P\{R S 3\} o r b^{C B-0909-3}$ & orb \\
\hline B & 3285 & $s t^{l} \operatorname{nos}^{L 7} e^{l} / T M 3, \mathrm{Sb}^{l} \mathrm{Ser}^{l}$ & nos \\
\hline $\mathrm{B}$ & 10063 & $w^{1118} ; f_{s}(3) *^{*} m w h^{l} P\{h s n e o\} b e l^{\text {neo30 }}$ red $^{l} e^{l} / T M 3, S^{l}$ Ser $^{l}$ & bel \\
\hline \multirow[t]{2}{*}{$\mathrm{B}$} & 15354 & $y^{l} w^{67 c 23} ; P\{E P g y 2\} m b c^{E Y 01437} / T M 3, S^{l} \mathrm{Ser}^{l}$ & $m b c$ \\
\hline & Törzs & Genotípus & Érintett gén \\
\hline B & 11373 & $w^{1118} ; P B a c\{P B\} \operatorname{casp}^{c 04227}$ & casp \\
\hline $\mathrm{B}$ & 6630 & $w^{*} ; C y c B^{2} / C y O, P\{f t z / l a c B\} E 3$ & $C y c B$ \\
\hline $\mathrm{B}$ & 10326 & $r y^{506} P\{P Z\} o r b^{d e c} / T M 3, r y^{R K} S^{l}{ }^{l} \operatorname{Ser}^{l}$ & orb \\
\hline B & 26473 & $w^{1118} ; M i\{E T 1\} C G 14545^{M B 09376}$ & CG14545 \\
\hline $\mathrm{Sz}$ & CB-5717-3 & $w^{1118} ; P\{R S 3\} R e p h^{C B-5717-3}$ & Reph \\
\hline B & 12940 & $y^{I} w^{67 c 23} ;$ P $\left\{\right.$ SUPor-P\}CG8116 ${ }^{K G 00606} r y^{506}$ & CG8116 \\
\hline K & 101689 & $\mathrm{Men}^{n N C 1} / \mathrm{TM6}$ & Men \\
\hline $\mathrm{B}$ & 2452 & $u^{l} \mathrm{pbl}^{5} h^{l} \mathrm{th}^{l} s t^{l} c u^{l} s r^{l} e^{s} c a^{l} / T M 3, S b^{l}$ & $p b l$ \\
\hline B & 20939 & $y^{1} w^{67 c 23} ; P\{E P g y 2\} c r q^{E Y 14489}$ & $c r q$ \\
\hline $\mathrm{H}$ & c01769 & $P B a c\{P B\} s c r a^{c 01769}$ & scra \\
\hline $\mathrm{B}$ & 16006 & $y^{I} w^{67 c 23} ; P\{E P g y 2\} m a e l^{E Y 08554}$ & mael \\
\hline $\mathrm{B}$ & 24320 & $\left.w^{1118} ; \mathrm{Mi}_{\{} \mathrm{ETl}\right\} \mathrm{knrl} \mathrm{MB05076}^{\mathrm{M}}$ & knrl \\
\hline B & 9358 & $w^{*} ; p b l^{3} / T M 3, S b^{l}$ & $p b l$ \\
\hline $\mathrm{H}$ & e00009 & $P B a c\{R B\}$ casp $^{e 00009}$ & casp \\
\hline $\mathrm{B}$ & 24682 & $w^{1118} ; M i\{E T 1\} C G 14838^{M B 04232} / T M 6 C, c u^{l} S b^{1}$ & CG14838 \\
\hline B & 9096 & $y^{l} w^{*} ; P\{l a c W\} 64 A C y c A^{H 170} t h^{l} s t^{l} c u^{l} s r^{l} e^{s} c a^{l} T M 6 B, P\{i a b-2(1.7) l a c Z\} 6 B, T b^{+}$ & CycA \\
\hline $\mathrm{B}$ & 4688 & $f e o^{E A 86} / F M 7 a$ & feo \\
\hline $\mathrm{H}$ & d09625 & $P\{X P\} d s x^{d 09625}$ & $d s x$ \\
\hline $\mathrm{B}$ & 17744 & $w^{1118} ; P B a c\{P B\} A o s I^{c 06048} / T M 6 B, T b^{l}$ & Aosl \\
\hline $\mathrm{B}$ & 5113 & $\operatorname{spir}^{l} \mathrm{cn}^{l} \mathrm{bw}^{l} / \mathrm{CyO}, \mathrm{l}(2) \mathrm{DTS} 513^{l}$ & spir \\
\hline $\mathrm{B}$ & 16319 & $y^{I} w^{1118} ; P B a c\left\{3 H P y^{+}\right\} C 255$ & CG7271 \\
\hline K & 104307 & $w^{*} ; P\{G a w B\} a d e 2^{N P 2741} / C y O$ & ade2 \\
\hline B & 9919 & $b w^{l} ; z p g^{z-5352} / T M 6 B, T b^{l}$ & zpg \\
\hline $\mathrm{B}$ & 11710 & $P\{P Z\} K l p 61 F^{07012} r y^{506} / T M 6 B, T b^{l}$ & Klp61F \\
\hline $\mathrm{H}$ & $\mathrm{d} 04507$ & $P\{X P\} C G 14438^{d 04507}$ & $C G 14438$ \\
\hline $\mathrm{B}$ & 20026 & $y^{I} w^{67 c 23} ; P\{E P g y 2\} C G 6543^{E Y 08499}$ & CG6543 \\
\hline $\mathrm{B}$ & 13025 & $y^{I} w^{67 c 23} ; P\{$ SUPor-P $\} n c l b^{K G 03665}$ & CG6751 \\
\hline $\mathrm{B}$ & 17559 & $y^{I} w^{67 c 23} ; P\{E P g y 2\} T 3 d h^{E Y 09338} p c^{E Y 09338}$ & $p g c$ \\
\hline $\mathrm{B}$ & 4952 & $s t^{l} e^{l} \mathrm{mbc}^{\mathrm{DIl.2}} / \mathrm{TM} 3, \mathrm{Ser}^{l}$ & $m b c$ \\
\hline $\mathrm{B}$ & 11554 & $P\{P Z\} l(3) 02094^{02094} r y^{506} / T M 3, r y^{R K} \mathrm{Sb}^{l} \mathrm{Ser}^{l}$ & CG13298 \\
\hline B & 8516 & $w^{*} ; m a e^{r 20} / T M 3, S b^{l}$ & mael \\
\hline B & 6234 & $\operatorname{In}(1) w^{m 4 h} ; \operatorname{Su}(\operatorname{var}) 205^{5} / \operatorname{In}(2 L) C y, \operatorname{In}(2 R) C y, C y^{l}$ & Su(var)205 \\
\hline $\mathrm{H}$ & $\mathrm{c} 04167$ & $P B a c\{P B\} m b c^{c 04167}$ & $m b c$ \\
\hline
\end{tabular}




\begin{tabular}{|c|c|c|c|}
\hline & Törzs & Genotípus & Érintett gén \\
\hline $\mathrm{H}$ & $\mathrm{c} 01936$ & $P B a c\{P B\} c r q^{c 01936}$ & crq \\
\hline B & 7347 & $y^{l} w^{67 c 23} ; P\left\{\right.$ Mae-UAS.6.11\}nos ${ }^{\text {UY4741 }}$ & nos \\
\hline B & 9918 & $\mathrm{zpg}^{z-2533} \mathrm{st}^{l} / T M 3, \mathrm{Sb}^{1}$ & zpg \\
\hline B & 4369 & $P\{l \text { ArB }\}_{\text {neur }}{ }^{A 01} r y^{506} / T M 3, r y^{R K} \mathrm{Sb}^{l} \mathrm{Ser}^{l}$ & neur \\
\hline B & 4286 & $s c r a^{8} c n^{l} b w^{l} s p^{l} / C y O$ & scra \\
\hline $\mathrm{H}$ & $\mathrm{c} 02473$ & $P B a c\{P B\} F s(2) K_{e t} t^{c 02473}$ & $F s(2) K e t$ \\
\hline $\mathrm{Sz}$ & SH0838 & $P\{l a c W\} l(2) S H 0838^{\text {SH0838 }}$ & Reph \\
\hline $\mathrm{B}$ & 3809 & $f e o^{l} / C(1) D X, y^{l} f^{l} / D p(1 ; Y) v^{+} y^{+} ; D p(? ; 2) b w^{D}, b w^{D}$ & feo \\
\hline B & 4222 & $r u^{l} h^{l} t^{l} s t^{l}$ neur ${ }^{l} c u^{l} s r^{l} e^{s} c a^{l} / T M 3, S b^{l}$ & neur \\
\hline $\mathrm{B}$ & 382 & $a d e 2^{I 0} / \operatorname{In}(2 L) C y, \operatorname{In}(2 R) C y, C y^{I}$ & ade2 \\
\hline B & 1671 & $\mathrm{red}^{l} \mathrm{e}^{l} \mathrm{mbc}^{C l} / T M 3$, PIftz-lacZ.ry $\left.{ }^{+}\right\} T M 3, \mathrm{Sb}^{l} r y^{*}$ & $m b c$ \\
\hline K & 101733 & $\operatorname{red}^{l} e^{l} m b c^{C 2} / T M 3, S b^{l} r y^{l} e^{l}$ & $m b c$ \\
\hline $\mathrm{B}$ & 24589 & $M i\{E T 1\} C G 4281^{M B 04586} w^{1118}$ & CG4281 \\
\hline $\mathrm{B}$ & 21722 & $P\{w H y\} C G 13298^{D G 20203}$ & CG13298 \\
\hline $\mathrm{B}$ & 4620 & $y^{l}$ ovo $o^{M 2} / F M 7 c$ & ovo \\
\hline $\mathrm{B}$ & 22200 & $y^{l} w^{*} ;$ P\{Mae-UAS.6.11\}LA00956a P\{Mae-UAS.6.11\}LA00956b & knrl \\
\hline $\mathrm{B}$ & 20206 & $y^{l} w^{67 c 23} ; P\{E P g y 2\} n c l b{ }^{E Y 10712}$ & CG6751 \\
\hline $\mathrm{Sz}$ & 136 & $P\{l a c W\} p b l^{S 008320}$ & $p b l$ \\
\hline $\mathrm{Sz}$ & 934 & $p b l^{S 054203 a}$ & $p b l$ \\
\hline $\mathrm{B}$ & 1679 & $D p(1 ; Y) B^{S} ; d s x^{l} p^{p} / T M 3, S b^{l}$ & $d s x$ \\
\hline $\mathrm{B}$ & 6020 & $d n c^{l}$ & $d n c$ \\
\hline $\mathrm{H}$ & $\mathrm{d} 02631$ & $P\{X P\}_{\text {spir }}{ }^{d 02631}$ & spir \\
\hline $\mathrm{K}$ & 200135 & $y^{l} w^{67 c 23} P\{G S V 1\}$ hang ${ }^{G S 1135} / C(1) D X, y^{l} f^{l}$ & hang \\
\hline $\mathrm{B}$ & 15145 & $y^{I} ; P\{S U P o r-P\} C y c B^{K G 08886} / C y O ; r y^{506}$ & $C y c B$ \\
\hline $\mathrm{B}$ & 7396 & $y^{l} w^{1118} d n c^{221 b} P\{n e o F R T\} 19 A / F M 6$ & $d n c$ \\
\hline $\mathrm{B}$ & 4994 & $F s(2) \mathrm{Ket}^{\text {lto2-l }} \mathrm{cn}^{l} \mathrm{bw}^{l} / \mathrm{CyO}, \mathrm{l}(2) \mathrm{DTS} 513^{l}$ & Fs(2)Ket \\
\hline $\mathrm{B}$ & 18676 & $w^{1118} ;$ PBac $\left\{\right.$ WH\}porin ${ }^{f 03616}$ & porin \\
\hline $\mathrm{B}$ & 16459 & $y^{l} ;$ P\{SUPor-P\}Reph ${ }^{K G 01552}$ & Reph \\
\hline $\mathrm{H}$ & f02870 & PBac $\{$ WH $\} K l p 61 F^{502870}$ & Klp61F \\
\hline $\mathrm{B}$ & 22571 & $y^{l} w^{67 c 23} P\{E P$ gy2 $\}$ hang ${ }^{\text {EY22604 }}$ & hang \\
\hline $\mathrm{H}$ & $\mathrm{c} 06825$ & $P B a c\{P B\} S u(v a r) 205^{c 06825}$ & $\mathrm{Su}($ var $) 205$ \\
\hline $\mathrm{B}$ & 15967 & $y^{l} w^{67 c 23} ; P\{E P g y 2\} F s(2) K e t^{E Y 06666} / C y O$ & $F s(2) K e t$ \\
\hline $\mathrm{B}$ & 4619 & $y^{l} o v o^{M l} c v^{l} v^{l} f^{l} / F M 7 c$ & ovo \\
\hline $\mathrm{B}$ & 5314 & $F s(2) K e t^{R X 3} l t^{l} b w^{l} / I n(2 L R) G l a, w g^{G l a-I}$ & Fs $(2)$ Ket \\
\hline B & 6627 & $w^{*} ; C y c A^{C 8 L R 1} / T M 3, S b^{l} P\{35 U Z\} 2$ & CycA \\
\hline B & 19457 & $\begin{array}{l}w^{*} ; P B a c\{G A L A D, E Y F P\} C G 32069^{P L 00327} \text { PBac }\{G A L A D, E Y F P\} S u U R^{P L 00327} \\
P\left\{F R T\left(w^{h s}\right)\right\} 2 A \text { P }\{\text { neoFRT }\} 82 B\end{array}$ & SuUR \\
\hline $\mathrm{B}$ & 17557 & $y^{I} P\{E P g y 2\} E Y 09320 w^{67 c 23}$ & Klp10A \\
\hline B & 25716 & $y^{l} w^{*} P\{l a c W\} m e i-P 26^{l} / C(1) D X, y^{l} f^{l} / D p(1 ; Y) y^{+} ; s v^{\text {spa-pol }}$ & mei-P26 \\
\hline $\mathrm{B}$ & 4445 & $\operatorname{In}(1) s c^{V 2}, s c^{V 2} ; S u U R^{E S}$ & SuUR \\
\hline $\mathrm{B}$ & 6236 & $\operatorname{In}(1) w^{m 4 h} ; \operatorname{Su}(v a r) 2-10^{l} / \operatorname{In}(2 L) C y^{L} t^{R}, \operatorname{In}(2 R) C y, C y^{l}$ amos $^{R o i-l} \mathrm{pr}^{l} \mathrm{cn}^{l}$ & Su(var)2-10 \\
\hline B & 10420 & $y^{l} w^{67 c 23} ; P\left\{\right.$ lacW\}Thiolase $e^{k 09828} / C y O$ & Thiolase \\
\hline
\end{tabular}




\begin{tabular}{|c|c|c|c|}
\hline & Törzs & Genotípus & Érintett gén \\
\hline $\mathrm{B}$ & 10563 & $y^{l} w^{67 c 23} ; P\left\{\right.$ lacW\}porin ${ }^{k 05123} / C y O$ & porin \\
\hline B & 938 & $D f(1) N-69 h 9, d n c^{69 h 9} r b^{l} / C(1) D X, y^{l} w^{l} f^{l} ; D p(1 ; 2) 51 b /+$ & $d n c$ \\
\hline K & 105135 & $y^{*} w^{*} P\{$ GawB $\} \operatorname{Tr} I^{N P 6119} / F M 7 c$ & Tre1 \\
\hline $\mathrm{B}$ & 20628 & $y^{l} w^{67 c 23} P\{E P g y 2\} C G 14438^{E Y 10575}$ & CG14438 \\
\hline K & 104019 & $y^{*} w^{*} P\{$ GawB $\} C G 14438^{N P 1526} / F M 7 c$ & $C G 14438$ \\
\hline $\mathrm{B}$ & 25717 & $y^{l} w^{l} m e i-P 26^{m f s} / F M 7 w ; s v^{\text {spa-pol }}$ & $m e i-P 26$ \\
\hline $\mathrm{B}$ & 22132 & $w^{I 118} P\{E P g\}$ eIF5 $5^{H P 10800}$ & eIF5 \\
\hline $\mathrm{H}$ & f02370 & $P B a c\{W H\} P h f^{f 02370}$ & $C G 9576$ \\
\hline B & 3605 & $w^{1118}$ & $w$ \\
\hline- & - & stau $^{43}$, osk $^{54}, \mathrm{TmII}^{\text {el4 }}$ & stau, osk, Tml \\
\hline
\end{tabular}

Függelék 2. táblázat: A kísérletek során felhasznált Drosophila törzsek. Az első oszlop a törzsek beszerzési forrását jelölik. B: Bloomingtoni törzsközpont (http://flystocks.bio.indiana.edu/). K: Kyotoi törzsközpont (http://kyotofly.kit.jp), H: Harvard Medical School törzsközpontja (https://drosophila.med.harvard.edu/), Sz: Szegedi törzsközpont (megszünt). 


\begin{tabular}{|c|c|c|c|c|c|c|c|c|c|c|c|c|c|c|}
\hline \multirow[t]{2}{*}{$\begin{array}{l}\text { Csende- } \\
\text { tített gén }\end{array}$} & \multirow[t]{2}{*}{$\begin{array}{c}\text { Kísér- } \\
\text { let }\end{array}$} & \multirow[t]{2}{*}{$\begin{array}{c}\text { Injektált } \\
\text { embrió }\end{array}$} & \multicolumn{2}{|c|}{$\begin{array}{c}\text { Csökkent } \\
\text { ivarsejt-szám }\end{array}$} & \multicolumn{2}{|c|}{$\begin{array}{l}\text { Ivarszerv- } \\
\text { kialakulás } \\
\text { hibája }\end{array}$} & \multicolumn{2}{|c|}{$\begin{array}{l}\text { Eltévedt } \\
\text { ivarsejtek }\end{array}$} & \multicolumn{2}{|c|}{$\begin{array}{c}\text { Embrionális } \\
\text { ivarszervek } \\
\text { hiánya }\end{array}$} & \multicolumn{2}{|c|}{$\begin{array}{l}\text { Középbélben } \\
\text { maradó } \\
\text { ivarsejtek }\end{array}$} & \multicolumn{2}{|c|}{$\begin{array}{c}\text { Csökevényes } \\
\text { ivarszervek } \\
\text { kifejlett } \\
\text { állatokban }\end{array}$} \\
\hline & & & $\%$ & átlag & $\%$ & átlag & $\%$ & átlag & $\%$ & átlag & $\%$ & átlag & $\%$ & átlag \\
\hline \multirow{7}{*}{$\begin{array}{l}\text { Pufferrel } \\
\text { injektált }\end{array}$} & 1.1 & 122 & 0.8 & \multirow{7}{*}{1.2} & 0.0 & \multirow{7}{*}{0.4} & 8.2 & \multirow{7}{*}{8.1} & 2.5 & \multirow{7}{*}{2.0} & 11.5 & \multirow{7}{*}{4.2} & 3.6 & \multirow{7}{*}{1.2} \\
\hline & 1.2 & 95 & 3.2 & & 0.0 & & 4.2 & & 4.2 & & 5.3 & & 0.0 & \\
\hline & 1.3 & 84 & 2.4 & & 0.0 & & 6.0 & & 0.0 & & 2.4 & & 0.0 & \\
\hline & 2.1 & 36 & 0.0 & & 2.8 & & 13.9 & & 2.8 & & 5.6 & & & \\
\hline & 2.2 & 43 & 0.0 & & 0.0 & & 9.3 & & 4.7 & & 2.3 & & & \\
\hline & 2.3 & 47 & 0.0 & & 0.0 & & 8.5 & & 0.0 & & 0.0 & & & \\
\hline & 2.4 & 47 & 2.1 & & 0.0 & & 6.4 & & 0.0 & & 2.1 & & & \\
\hline \multirow{4}{*}{ ade2 } & 1.1 & 40 & 0.0 & \multirow{4}{*}{0.0} & 0.0 & \multirow{4}{*}{0.0} & 32.5 & & 15.0 & & 15.0 & & 0.0 & \\
\hline & 1.2 & 40 & 0.0 & & 0.0 & & 17.5 & 241 & 2.5 & & 15.0 & & 0.0 & \\
\hline & 2.1 & 62 & 0.0 & & 0.0 & & 22.6 & 24.4 & 1.6 & 3.4 & 17.7 & 18.2 & 0.0 & 0.0 \\
\hline & 2.2 & 40 & 0.0 & & 0.0 & & 25.0 & & 2.5 & & 25.0 & & 0.0 & \\
\hline & 1.1 & 40 & 0.0 & & 0.0 & & 55.0 & & 5.0 & & 17.5 & & 50.0 & \\
\hline & 1.2 & 49 & 0.0 & & 0.0 & & 14.3 & & 0.0 & & 8.2 & & 6.3 & \\
\hline Aos1 & 2.1 & 20 & 0.0 & 0.0 & 0.0 & 0.0 & 30.0 & 28.7 & 0.0 & 1.3 & 5.0 & 11.6 & 0.0 & 17.9 \\
\hline & 2.2 & 45 & 0.0 & & 0.0 & & 15.6 & & 0.0 & & 15.6 & & 15.4 & \\
\hline & 1.1 & 24 & 0.0 & & 0.0 & & 12.5 & & 41.7 & & 54.2 & & 0.0 & \\
\hline hel & 1.2 & 21 & 14.3 & 36 & 0.0 & م0 & 28.6 & 303 & 14.3 & 165 & 23.8 & 307 & 0.0 & ת م0 \\
\hline bel & 2.1 & 40 & 0.0 & 3.6 & 0.0 & 0.0 & 32.5 & 20.3 & 5.0 & 16.5 & 22.5 & 30.1 & 0.0 & 0.0 \\
\hline & 2.2 & 40 & 0.0 & & 0.0 & & 7.5 & & 5.0 & & 22.5 & & 0.0 & \\
\hline & 1.1 & 77 & 19.5 & & 0.0 & & 2.6 & & 3.9 & & 3.9 & & 9.4 & \\
\hline D & 1.2 & 43 & 9.3 & 116 & 14.0 & 10 & 11.6 & 16 & 0.0 & 10 & 4.7 & 7 & 8.3 & 11 \\
\hline BSgZSD & 2.1 & 46 & 6.5 & 14.6 & 2.2 & 4.0 & 4.3 & 4.6 & 0.0 & 1.0 & 2.2 & 2.1 & 0.0 & 4.4 \\
\hline & 2.2 & 39 & 23.1 & & 0.0 & & 0.0 & & 0.0 & & 0.0 & & 0.0 & \\
\hline & 1.1 & 32 & 0.0 & & 0.0 & & 21.9 & & 6.3 & & 25.0 & & 13.6 & \\
\hline & 1.2 & 42 & 0.0 & & 0.0 & & 23.8 & & 7.1 & 72 & 19.0 & & 7.1 & \\
\hline casp & 2.1 & 36 & 0.0 & 0.0 & 0.0 & 0.0 & 44.4 & $2 / .5$ & 11.1 & 1.2 & 27.8 & 22.4 & 0.0 & 6.6 \\
\hline & 2.2 & 45 & 0.0 & & 0.0 & & 20.0 & & 4.4 & & 17.8 & & 5.6 & \\
\hline & 1.1 & 32 & 18.8 & & 0.0 & & 25.0 & & 21.9 & & 3.1 & & 15.0 & \\
\hline CG4281 & 1.2 & 51 & 2.0 & 52 & 0.0 & 0 & 49.0 & 308 & 7.8 & 74 & 17.6 & 152 & 0.0 & 38 \\
\hline$C 04281$ & 2.1 & 45 & 0.0 & & 0.0 & 0.0 & 31.1 & & 0.0 & 1.4 & 22.2 & 13.2 & 0.0 & 3.8 \\
\hline & 2.2 & 39 & 0.0 & & 0.0 & & 17.9 & & 0.0 & & 17.9 & & 0.0 & \\
\hline & 1.1 & 30 & 0.0 & & 0.0 & & 33.3 & & 0.0 & & 33.3 & & 0.0 & \\
\hline CG6751 & 1.2 & 40 & 0.0 & & 0.0 & & 27.5 & & 0.0 & & 30.0 & & 6.5 & 22 \\
\hline CGb/S1 & 2.1 & 25 & 0.0 & 0.0 & 0.0 & 0.0 & 32.0 & 21.4 & 0.0 & 0.0 & 64.0 & 38.1 & 0.0 & 2.2 \\
\hline & 2.2 & 36 & 0.0 & & 0.0 & & 16.7 & & 0.0 & & 25.0 & & 0.0 & \\
\hline & 1.1 & 47 & 0.0 & & 0.0 & & 29.8 & & 0.0 & & 40.4 & & 0.0 & \\
\hline Cco11 & 1.2 & 35 & 0.0 & ק0 & 0.0 & م0 & 25.7 & 256 & 0.0 & 10 & 51.4 & 272 & 0.0 & 20 \\
\hline $\cos 110$ & 2.1 & 56 & 0.0 & 0.0 & 0.0 & 0.0 & 42.9 & 33.6 & 7.1 & 1.8 & 33.9 & 31.3 & 0.0 & 3.8 \\
\hline & 2.2 & 34 & 0.0 & & 0.0 & & 44.1 & & 0.0 & & 23.5 & & 15.0 & \\
\hline & 1.1 & 53 & 0.0 & & 0.0 & & 28.3 & & 3.8 & & 22.6 & & 10.4 & \\
\hline & 1.2 & 48 & 2.1 & & 0.0 & م0 & 25.0 & 271 & 4.2 & 61 & 31.3 & 265 & 3.6 & 35 \\
\hline CG95/6 & 2.1 & 35 & 0.0 & 0.5 & 0.0 & 0.0 & 31.4 & 27.1 & 8.6 & 6.1 & 28.6 & 26.5 & 0.0 & 3.5 \\
\hline & 2.2 & 38 & 0.0 & & 0.0 & & 23.7 & & 7.9 & & 23.7 & & 0.0 & \\
\hline
\end{tabular}




\begin{tabular}{|c|c|c|c|c|c|c|c|c|c|c|c|c|c|c|}
\hline \multirow[t]{2}{*}{$\begin{array}{l}\text { Csendesí- } \\
\text { tett gén }\end{array}$} & \multirow[t]{2}{*}{$\begin{array}{l}\text { Kísér- } \\
\text { let }\end{array}$} & \multirow[t]{2}{*}{$\begin{array}{c}\text { Injektált } \\
\text { embrió }\end{array}$} & \multicolumn{2}{|c|}{$\begin{array}{l}\text { Csökkent } \\
\text { ivarsejt-szám }\end{array}$} & \multicolumn{2}{|c|}{$\begin{array}{l}\text { Ivarszerv- } \\
\text { kialakulás } \\
\text { hibája }\end{array}$} & \multicolumn{2}{|c|}{$\begin{array}{l}\text { Eltévedt } \\
\text { ivarsejtek }\end{array}$} & \multicolumn{2}{|c|}{$\begin{array}{c}\text { Embrionális } \\
\text { ivarszervek } \\
\text { hiánya }\end{array}$} & \multicolumn{2}{|c|}{$\begin{array}{c}\text { Középbélben } \\
\text { maradó } \\
\text { ivarsejtek }\end{array}$} & \multicolumn{2}{|c|}{$\begin{array}{c}\text { Csökevényes } \\
\text { ivarszervek } \\
\text { kifejlett } \\
\text { állatokban }\end{array}$} \\
\hline & & & $\%$ & átlag & $\%$ & átlag & $\%$ & átlag & $\%$ & átlag & $\%$ & átlag & átlag & $\%$ \\
\hline \multirow{4}{*}{ CG13298 } & 1.1 & 40 & 0.0 & \multirow{4}{*}{2.7} & 0.0 & \multirow{4}{*}{0.0} & 10.0 & \multirow{4}{*}{22.8} & 2.5 & \multirow{4}{*}{4.8} & 12.5 & \multirow{4}{*}{15.0} & 18.2 & \multirow{4}{*}{9.9} \\
\hline & 1.2 & 25 & 4.0 & & 0.0 & & 8.0 & & 0.0 & & 12.0 & & 21.4 & \\
\hline & 2.1 & 24 & 4.2 & & 0.0 & & 62.5 & & 16.7 & & 25.0 & & 0.0 & \\
\hline & 2.2 & 38 & 2.6 & & 0.0 & & 10.5 & & 0.0 & & 10.5 & & 0.0 & \\
\hline \multirow{4}{*}{ CG14438 } & 1.1 & 43 & 0.0 & \multirow{4}{*}{0.7} & 0.0 & \multirow{4}{*}{0.0} & 7.0 & & 2.3 & & 14.0 & & 22.6 & \\
\hline & 1.2 & 42 & 0.0 & & 0.0 & & 7.1 & 117 & 7.1 & & 14.3 & & 75.0 & \\
\hline & 2.1 & 23 & 0.0 & & 0.0 & & 21.7 & 11.1 & 17.4 & 7.4 & 30.4 & 17.4 & 0.0 & 26.5 \\
\hline & 2.2 & 37 & 2.7 & & 0.0 & & 10.8 & & 2.7 & & 10.8 & & 8.3 & \\
\hline & 1.1 & 35 & 2.9 & & 0.0 & & 17.1 & & 0.0 & & 22.9 & & 13.0 & \\
\hline & 1.2 & 38 & 5.3 & & 0.0 & & 28.9 & & 10.5 & & 31.6 & & 37.5 & \\
\hline CG14545 & 2.1 & 43 & 2.3 & 2.6 & 0.0 & 0.0 & 34.9 & 22.2 & 4.7 & 4.3 & 23.3 & 19.9 & 25.0 & 35.6 \\
\hline & 2.2 & 51 & 0.0 & & 0.0 & & 7.8 & & 2.0 & & 2.0 & & 66.7 & \\
\hline & 1.1 & 35 & 0.0 & & 0.0 & & 37.1 & & 0.0 & & 22.9 & & 0.0 & \\
\hline & 1.2 & 48 & 2.1 & & 0.0 & & 16.7 & & 0.0 & & 8.3 & 230 & 4.6 & \\
\hline CG14838 & 2.1 & 38 & 0.0 & 0.5 & 0.0 & 0.0 & 23.7 & 27.9 & 0.0 & 0.0 & 39.5 & 23.9 & 0.0 & 2.5 \\
\hline & 2.2 & 44 & 0.0 & & 0.0 & & 34.1 & & 0.0 & & 25.0 & & 2.9 & \\
\hline & 1.1 & 49 & 0.0 & & 0.0 & & 36.7 & & 4.1 & & 28.6 & & 8.3 & \\
\hline & 1.2 & 44 & 4.5 & & 0.0 & & 40.9 & & 4.5 & & 13.6 & & 4.2 & \\
\hline CG17658 & 2.1 & 21 & 0.0 & 2.2 & 0.0 & 0.0 & 52.4 & 39.0 & 0.0 & 2.2 & 23.8 & 23.0 & 0.0 & 4.2 \\
\hline & 2.2 & 46 & 4.3 & & 0.0 & & 26.1 & & 0.0 & & 26.1 & & 0.0 & \\
\hline & 1.1 & 52 & 0.0 & & 0.0 & & 25.0 & & 0.0 & & 15.4 & & 11.8 & \\
\hline & 1.2 & 40 & 0.0 & & 0.0 & & 32.5 & & 0.0 & & 7.5 & 10 & 3.1 & \\
\hline crq & 2.1 & 23 & 0.0 & 0.0 & 0.0 & 0.0 & 34.8 & 27.6 & 0.0 & 0.0 & 34.8 & 18.4 & 0.0 & 5.5 \\
\hline & 2.2 & 44 & 0.0 & & 0.0 & & 18.2 & & 0.0 & & 15.9 & & 7.1 & \\
\hline & 1.1 & 34 & 0.0 & & 0.0 & & 38.2 & & 8.8 & & 23.5 & & 12.5 & \\
\hline & 1.2 & 9 & 0.0 & & 0.0 & & 55.6 & & 11.1 & & 11.1 & & 0.0 & \\
\hline СусA & 2.1 & 38 & 0.0 & 0.6 & 0.0 & 0.0 & 39.5 & 36.9 & 5.3 & 7.5 & 36.8 & 20.3 & 0.0 & 3.1 \\
\hline & 2.2 & 42 & 2.4 & & 0.0 & & 14.3 & & 4.8 & & 9.5 & & 0.0 & \\
\hline & 1.1 & 20 & 0.0 & & 0.0 & & 15.0 & & 10.0 & & 10.0 & & 8.3 & \\
\hline & 1.2 & 11 & 9.1 & & 0.0 & & 18.2 & & 9.1 & & 0.0 & & 50.0 & \\
\hline СусВ & 2.1 & 32 & 0.0 & 2.3 & 0.0 & 0.0 & 43.8 & 25.1 & 9.4 & 7.1 & 15.6 & 12.3 & 0.0 & 14.6 \\
\hline & 2.2 & 17 & 0.0 & & 0.0 & & 23.5 & & 0.0 & & 23.5 & & 0.0 & \\
\hline & 1.1 & 54 & 3.7 & & 0.0 & & 25.9 & & 1.9 & & 13.0 & & 17.6 & \\
\hline & 1.2 & 44 & 0.0 & & 0.0 & & 20.5 & & 0.0 & & 11.4 & & 0.0 & \\
\hline dnc & 2.1 & 39 & 0.0 & 0.9 & 0.0 & 0.0 & 7.7 & 17.7 & 0.0 & 0.5 & 10.3 & 15.6 & 6.3 & 6.0 \\
\hline & 2.2 & 36 & 0.0 & & 0.0 & & 16.7 & & 0.0 & & 27.8 & & 0.0 & \\
\hline & 1.1 & 63 & 0.0 & & 0.0 & & 14.3 & & 3.2 & & 17.5 & & 32.4 & \\
\hline & 1.2 & 39 & 0.0 & & 0.0 & & 17.9 & & 0.0 & & 15.4 & & 4.2 & \\
\hline dsx & 2.1 & 49 & 0.0 & 0.0 & 0.0 & 0.0 & 2.0 & 10.7 & 0.0 & 0.8 & 16.3 & 17.7 & 20.0 & 16.9 \\
\hline & 2.2 & 46 & 0.0 & & 0.0 & & 8.7 & & 0.0 & & 21.7 & & 11.1 & \\
\hline & 1.1 & 40 & 0.0 & & 0.0 & & 12.5 & & 0.0 & & 15.0 & & 11.1 & \\
\hline & 1.2 & 42 & 0.0 & & 0.0 & & 7.1 & & 0.0 & & 23.8 & & 6.3 & \\
\hline elF5 & 2.1 & 28 & 0.0 & 0.8 & 0.0 & 0.0 & 0.0 & 10.2 & 0.0 & 0.0 & 10.7 & 16.2 & 0.0 & 5.8 \\
\hline & 2.2 & 33 & 3.0 & & 0.0 & & 21.2 & & 0.0 & & 15.2 & & 0.0 & \\
\hline
\end{tabular}




\begin{tabular}{|c|c|c|c|c|c|c|c|c|c|c|c|c|c|c|}
\hline \multirow[t]{2}{*}{$\begin{array}{l}\text { Csende- } \\
\text { sített gén }\end{array}$} & \multirow[t]{2}{*}{$\begin{array}{l}\text { Kísér- } \\
\text { let }\end{array}$} & \multirow[t]{2}{*}{$\begin{array}{c}\text { Injektált } \\
\text { embrió }\end{array}$} & \multicolumn{2}{|c|}{$\begin{array}{l}\text { Csökkent } \\
\text { ivarsejt-szám }\end{array}$} & \multicolumn{2}{|c|}{$\begin{array}{l}\text { Ivarszerv- } \\
\text { kialakulás } \\
\text { hibája }\end{array}$} & \multicolumn{2}{|c|}{$\begin{array}{c}\text { Eltévedt } \\
\text { ivarsejtek }\end{array}$} & \multicolumn{2}{|c|}{$\begin{array}{c}\text { Embrionális } \\
\text { ivarszervek } \\
\text { hiánya }\end{array}$} & \multicolumn{2}{|c|}{$\begin{array}{c}\text { Középbélben } \\
\text { maradó } \\
\text { ivarsejtek }\end{array}$} & \multicolumn{2}{|c|}{$\begin{array}{c}\text { Csökevényes } \\
\text { ivarszervek } \\
\text { kifejlett } \\
\text { állatokban }\end{array}$} \\
\hline & & & $\%$ & átlag & $\%$ & átlag & $\%$ & átlag & $\%$ & átlag & & $\%$ & átlag & $\%$ \\
\hline \multirow{4}{*}{ feo } & 1.1 & 34 & 2.9 & \multirow{4}{*}{3.7} & 0.0 & \multirow{4}{*}{0.0} & 2.9 & \multirow{4}{*}{3.0} & 2.9 & \multirow{4}{*}{3.0} & 0.0 & \multirow{4}{*}{4.8} & 60.0 & \multirow{4}{*}{57.} \\
\hline & 1.2 & 51 & 11.8 & & 0.0 & & 2.0 & & 2.0 & & 2.0 & & 36.7 & \\
\hline & 2.1 & 18 & 0.0 & & 0.0 & & 0.0 & & 0.0 & & 5.6 & & 0.0 & \\
\hline & 2.2 & 43 & 0.0 & & 0.0 & & 7.0 & & 7.0 & & 11.6 & & 75.0 & \\
\hline \multirow{4}{*}{ hang } & 1.1 & 35 & 2.9 & \multirow{4}{*}{1.3} & 0.0 & \multirow{4}{*}{0.0} & 40.0 & & 5.7 & & 14.3 & & 33.3 & \\
\hline & 1.2 & 40 & 2.5 & & 0.0 & & 12.5 & 203 & 0.0 & 27 & 15.0 & 138 & 10.0 & 150 \\
\hline & 2.1 & 36 & 0.0 & & 0.0 & & 16.7 & 20.3 & 0.0 & 2.2 & 13.9 & 13.8 & 16.7 & 15.0 \\
\hline & 2.2 & 33 & 0.0 & & 0.0 & & 12.1 & & 3.0 & & 12.1 & & 0.0 & \\
\hline & 1.1 & 53 & 1.9 & & 0.0 & & 22.6 & & 5.7 & & 13.2 & & 23.5 & \\
\hline $\mathrm{Fc}_{\mathrm{c}}(2) \mathrm{Kot}$ & 1.2 & 46 & 0.0 & 05 & 0.0 & תم & 19.6 & 185 & 0.0 & 14 & 13.0 & 161 & 25.0 & 121 \\
\hline rs(z)Ket & 2.1 & 25 & 0.0 & 0.5 & 0.0 & 0.0 & 24.0 & 18.5 & 0.0 & 1.4 & 24.0 & 16.4 & 0.0 & 12.1 \\
\hline & 2.2 & 26 & 0.0 & & 0.0 & & 7.7 & & 0.0 & & 15.4 & & 0.0 & \\
\hline & 1.1 & 19 & 0.0 & & 0.0 & & 63.2 & & 0.0 & & 36.8 & & 0.0 & \\
\hline Kln10A & 1.2 & 41 & 0.0 & م0 & 0.0 & תم & $\begin{array}{ll}17.1 \\
\end{array}$ & 367 & 0.0 & 18 & \begin{tabular}{|l|l}
17.1 \\
\end{tabular} & 200 & 3.6 & 0 \\
\hline KIр10A & 2.1 & 22 & 0.0 & 0.0 & 0.0 & 0.0 & 45.5 & 36.1 & 4.5 & 1.8 & 18.2 & 20.0 & 0.0 & 0.9 \\
\hline & 2.2 & 38 & 0.0 & & 0.0 & & 21.1 & & 2.6 & & 7.9 & & 0.0 & \\
\hline & 1.1 & 37 & 2.7 & & 0.0 & & 40.5 & & 2.7 & & 10.8 & & 0.0 & \\
\hline & 1.2 & 50 & 0.0 & 07 & 0.0 & & 30.0 & & 4.0 & 21 & 12.0 & 166 & 0.0 & \\
\hline KIp61F & 2.1 & 33 & 0.0 & 0.1 & 0.0 & 0.0 & 39.4 & 30.5 & 3.0 & 2.4 & 24.2 & 16.6 & 0.0 & 0.0 \\
\hline & 2.2 & 41 & 0.0 & & 0.0 & & 12.2 & & 0.0 & & 19.5 & & 0.0 & \\
\hline & 1.1 & 42 & 2.4 & & 2.4 & & 33.3 & & 11.9 & & 2.4 & & 15.9 & \\
\hline & 1.2 & 42 & 2.4 & 12 & 4.8 & & 16.7 & 221 & 4.8 & 12 & 2.4 & 155 & 20.0 & 132 \\
\hline knrl & 2.1 & 26 & 0.0 & 1.2 & 0.0 & 1.8 & 19.2 & 22.4 & 0.0 & 4.2 & 30.8 & 15.5 & 7.1 & 13.3 \\
\hline & 2.2 & 49 & 0.0 & & 0.0 & & 20.4 & & 0.0 & & 26.5 & & 10.0 & \\
\hline & 1.1 & 63 & 15.9 & & 0.0 & & 28.6 & & 9.5 & & 7.9 & & 0.0 & \\
\hline & 1.2 & 48 & 0.0 & & 2.1 & & 31.3 & & 4.2 & & 8.3 & & 3.6 & \\
\hline Reph & 2.1 & 20 & 5.0 & 5.2 & 0.0 & 0.5 & 15.0 & 19.4 & 0.0 & 4.1 & 10.0 & 15.1 & 0.0 & 1.6 \\
\hline & 2.2 & 35 & 0.0 & & 0.0 & & 2.9 & & 2.9 & & 34.3 & & 2.6 & \\
\hline & 1.1 & 60 & 1.7 & & 0.0 & & 26.7 & & 8.3 & & 6.7 & & 22.2 & \\
\hline & 1.2 & 23 & 0.0 & & 4.3 & & 21.7 & & 0.0 & & 0.0 & & 0.0 & \\
\hline mael & 2.1 & 46 & 2.2 & 1.0 & 0.0 & 1.1 & 10.9 & 20.0 & 0.0 & 2.1 & 17.4 & 8.6 & 0.0 & 5.6 \\
\hline & 2.2 & 48 & 0.0 & & 0.0 & & 20.8 & & 0.0 & & 10.4 & & 0.0 & \\
\hline & 1.1 & 65 & 3.1 & & 0.0 & & 53.8 & & 18.5 & & 18.5 & & 0.0 & \\
\hline $\mathrm{mbc}$ & 2.1 & 25 & 0.0 & 1.0 & 0.0 & 0.8 & 68.0 & 57.3 & 4.0 & 10.5 & 32.0 & 26.7 & 0.0 & 4.2 \\
\hline & 2.2 & 44 & 0.0 & & 2.3 & & 50.0 & & 9.1 & & 29.5 & & 12.5 & \\
\hline & 1.1 & 46 & 4.3 & & 0.0 & & 8.7 & & 10.9 & & 15.2 & & 8.7 & \\
\hline & 1.2 & 48 & 6.3 & & 0.0 & & 14.6 & & 2.1 & & 12.5 & & 15.0 & \\
\hline Men & 2.1 & 29 & 3.4 & 3.5 & 0.0 & 0.0 & 17.2 & 10.7 & 3.4 & 4.1 & 20.7 & 15.1 & 0.0 & 7.5 \\
\hline & 2.2 & 42 & 0.0 & & 0.0 & & 2.4 & & 0.0 & & 11.9 & & 6.3 & \\
\hline & 1.1 & 53 & 1.9 & & 5.7 & & 18.9 & & 7.5 & & 7.5 & & 23.3 & \\
\hline & 1.2 & 48 & 0.0 & & 10.4 & & 56.3 & & 16.7 & & 16.7 & & 0.0 & \\
\hline neur & 2.1 & 37 & 2.7 & 1.1 & 5.4 & 10.2 & 35.1 & 28.8 & 5.4 & 7.4 & 24.3 & 13.4 & 0.0 & 7.8 \\
\hline & 2.2 & 41 & 0.0 & & 19.5 & & 4.9 & & 0.0 & & 4.9 & & 0.0 & \\
\hline
\end{tabular}




\begin{tabular}{|c|c|c|c|c|c|c|c|c|c|c|c|c|c|c|}
\hline \multirow[t]{2}{*}{$\begin{array}{l}\text { Csende- } \\
\text { sített gén }\end{array}$} & \multirow[t]{2}{*}{$\begin{array}{c}\text { Kísér- } \\
\text { let }\end{array}$} & \multirow[t]{2}{*}{$\begin{array}{l}\text { Injektált } \\
\text { embrió }\end{array}$} & \multicolumn{2}{|c|}{$\begin{array}{l}\text { Csökkent } \\
\text { ivarsejt-szám }\end{array}$} & \multicolumn{2}{|c|}{$\begin{array}{l}\text { Ivarszerv- } \\
\text { kialakulás } \\
\text { hibája }\end{array}$} & \multicolumn{2}{|c|}{$\begin{array}{l}\text { Eltévedt } \\
\text { ivarsejtek }\end{array}$} & \multicolumn{2}{|c|}{$\begin{array}{l}\text { Embrionális } \\
\text { ivarszervek } \\
\text { hiánya }\end{array}$} & \multicolumn{2}{|c|}{$\begin{array}{l}\text { Középbélben } \\
\text { maradó } \\
\text { ivarsejtek }\end{array}$} & \multicolumn{2}{|c|}{$\begin{array}{c}\text { Csökevényes } \\
\text { ivarszervek } \\
\text { kifejlett } \\
\text { állatokban } \\
\end{array}$} \\
\hline & & & $\%$ & átlag & $\%$ & átlag & $\%$ & átlag & $\%$ & átlag & $\%$ & átlag & átlag & $\%$ \\
\hline \multirow{4}{*}{ orb } & 1.1 & 40 & 20.0 & \multirow{4}{*}{9.8} & 0.0 & \multirow{4}{*}{0.7} & 10.0 & \multirow{4}{*}{15.3} & 10.0 & \multirow{4}{*}{2.5} & 0.0 & \multirow{4}{*}{6.0} & 8.3 & \multirow{4}{*}{2.1} \\
\hline & 1.2 & 44 & 6.8 & & 0.0 & & 18.2 & & 0.0 & & 6.8 & & 0.0 & \\
\hline & 2.1 & 14 & 7.1 & & 0.0 & & 14.3 & & 0.0 & & 14.3 & & 0.0 & \\
\hline & 2.2 & 37 & 5.4 & & 2.7 & & 18.9 & & 0.0 & & 2.7 & & 0.0 & \\
\hline \multirow{4}{*}{ ovo } & 1.1 & 71 & 23.9 & \multirow{4}{*}{10.6} & 7.0 & \multirow{4}{*}{5.3} & 21.1 & & 19.7 & & 5.6 & & 87.5 & \\
\hline & 1.2 & 35 & 2.9 & & 2.9 & & 22.9 & 218 & 0.0 & 63 & 0.0 & 99 & 22.2 & 162 \\
\hline & 2.1 & 30 & 10.0 & & 0.0 & & 10.0 & 21.8 & 0.0 & 6.3 & 20.0 & 9.9 & 25.0 & 46.2 \\
\hline & 2.2 & 36 & 5.6 & & 11.1 & & 33.3 & & 5.6 & & 13.9 & & 50.0 & \\
\hline & 1.1 & 61 & 19.7 & & 4.9 & & 16.4 & & 9.8 & & 1.6 & & 0.0 & \\
\hline & 1.2 & 28 & 3.6 & & 14.3 & & 39.3 & 131 & 32.1 & & 7.1 & & 0.0 & م0 \\
\hline pbl & 2.1 & 29 & 6.9 & 8.5 & 6.9 & 6.5 & 44.8 & 43.4 & 41.4 & 26.6 & 10.3 & 5.1 & 0.0 & 0.0 \\
\hline & 2.2 & 26 & 3.8 & & 0.0 & & 73.1 & & 23.1 & & 3.8 & & 0.0 & \\
\hline & 1.1 & 48 & 0.0 & & 2.1 & & 25.0 & & 2.1 & & 8.3 & & 14.3 & \\
\hline & 1.2 & 37 & 2.7 & & 0.0 & & 21.6 & & 0.0 & 11 & 2.7 & & 7.7 & 01 \\
\hline Pglym/8 & 2.1 & 19 & 0.0 & 1.2 & 0.0 & 0.5 & 15.8 & 21.5 & 0.0 & 1.1 & 5.3 & 4.6 & 14.3 & 9.1 \\
\hline & 2.2 & 44 & 2.3 & & 0.0 & & 47.7 & & 2.3 & & 2.3 & & 0.0 & \\
\hline & 1.1 & 73 & 6.8 & & 0.0 & & 28.8 & & 5.5 & & 6.8 & & 8.3 & \\
\hline & 1.2 & 39 & 0.0 & & 0.0 & & 38.5 & & 2.6 & & 2.6 & & 8.3 & \\
\hline porin & 2.1 & 25 & 4.0 & 2.1 & 0.0 & 0.0 & 20.0 & 33.9 & 4.0 & 4.6 & 16.0 & 8.0 & 16.7 & 8.3 \\
\hline & 2.2 & 31 & 0.0 & & 0.0 & & 48.4 & & 6.5 & & 6.5 & & 0.0 & \\
\hline & 1.1 & 48 & 27.1 & & 0.0 & & 8.3 & & 4.2 & & 4.2 & & 0.0 & \\
\hline & 1.2 & 50 & 12.0 & 121 & 0.0 & & 10.0 & & 2.0 & & 2.0 & & 0.0 & \\
\hline scra & 2.1 & 25 & 8.0 & 13.4 & 0.0 & 3.2 & 8.0 & 9.8 & 0.0 & 1.5 & 8.0 & 3.5 & 0.0 & 3.3 \\
\hline & 2.2 & 31 & 6.5 & & 12.9 & & 12.9 & & 0.0 & & 0.0 & & 10.0 & \\
\hline & 1.1 & 38 & 15.8 & & 0.0 & & 13.2 & & 2.6 & & 5.3 & & 14.3 & \\
\hline & 1.2 & 42 & 0.0 & & 0.0 & & 4.8 & & 0.0 & & 0.0 & & 3.9 & \\
\hline spir & 2.1 & 43 & 2.3 & 4.5 & 0.0 & 0.5 & 4.7 & 10.7 & 0.0 & 0.7 & 11.6 & 4.7 & 0.0 & 8.2 \\
\hline & 2.2 & 49 & 0.0 & & 2.0 & & 20.4 & & 0.0 & & 2.0 & & 14.7 & \\
\hline & 1.1 & 30 & 3.3 & & 0.0 & & 3.3 & & 0.0 & & 0.0 & & 40.0 & \\
\hline Su(var) & 1.2 & 41 & 2.4 & & 14.6 & & 4.9 & & 0.0 & & 0.0 & & 40.0 & \\
\hline $2-10$ & 2.1 & 38 & 2.6 & 2.1 & 0.0 & 3.7 & 0.0 & 4.8 & 0.0 & 2.2 & 21.1 & 10.7 & 18.2 & 38.1 \\
\hline & 2.2 & 46 & 0.0 & & 0.0 & & 10.9 & & 8.7 & & 21.7 & & 54.2 & \\
\hline & 1.1 & 61 & 41.0 & & 0.0 & & 1.6 & & 1.6 & & 1.6 & & 40.5 & \\
\hline Su(var) & 1.2 & 40 & 7.5 & & 0.0 & & 5.0 & & 0.0 & & 2.5 & & 7.7 & \\
\hline 205 & 2.1 & 39 & 0.0 & 12.1 & 0.0 & 0.0 & 5.1 & 11.6 & 0.0 & 0.4 & 10.3 & 5.5 & 33.3 & 24.5 \\
\hline & 2.2 & 26 & 0.0 & & 0.0 & & 34.6 & & 0.0 & & 7.7 & & 16.7 & \\
\hline & 1.1 & 54 & 48.1 & & 0.0 & & 7.4 & & 22.2 & & 1.9 & & 6.7 & \\
\hline & 1.2 & 44 & 20.5 & & 0.0 & & 15.9 & & 0.0 & & 0.0 & & 9.1 & \\
\hline SuUR & 2.1 & 29 & 10.3 & 21.3 & 0.0 & 0.5 & 6.9 & 9.1 & 3.4 & 6.9 & 13.8 & 7.0 & 0.0 & 3.9 \\
\hline & 2.2 & 49 & 6.1 & & 2.0 & & 6.1 & & 2.0 & & 12.2 & & 0.0 & \\
\hline & 1.1 & 60 & 13.3 & & 10.0 & & 18.3 & & 3.3 & & 6.7 & & 10.0 & \\
\hline & 1.2 & 47 & 6.4 & & 8.5 & & 8.5 & & 0.0 & & 2.1 & & 4.2 & \\
\hline Thiolase & 2.1 & 52 & 1.9 & 5.4 & 3.8 & 10.4 & 9.6 & 15.7 & 0.0 & 0.8 & 23.1 & 8.6 & 5.6 & 4.9 \\
\hline & 2.2 & 42 & 0.0 & & 19.0 & & 26.2 & & 0.0 & & 2.4 & & 0.0 & \\
\hline
\end{tabular}




\begin{tabular}{|c|c|c|c|c|c|c|c|c|c|c|c|c|c|c|}
\hline \multirow[t]{2}{*}{$\begin{array}{l}\text { Csende- } \\
\text { sített gén }\end{array}$} & \multirow[t]{2}{*}{$\begin{array}{l}\text { Kísér- } \\
\text { let }\end{array}$} & \multirow[t]{2}{*}{$\begin{array}{l}\text { Injektált } \\
\text { embrió }\end{array}$} & \multicolumn{2}{|c|}{$\begin{array}{c}\text { Csökkent } \\
\text { ivarsejt-szám }\end{array}$} & \multicolumn{2}{|c|}{$\begin{array}{l}\text { Ivarszerv- } \\
\text { kialakulás } \\
\text { hibája }\end{array}$} & \multicolumn{2}{|c|}{$\begin{array}{c}\text { Eltévedt } \\
\text { ivarsejtek }\end{array}$} & \multicolumn{2}{|c|}{$\begin{array}{c}\text { Embrionális } \\
\text { ivarszervek } \\
\text { hiánya }\end{array}$} & \multicolumn{2}{|c|}{$\begin{array}{c}\text { Középbélben } \\
\text { maradó } \\
\text { ivarsejtek }\end{array}$} & \multicolumn{2}{|c|}{$\begin{array}{c}\text { Csökevényes } \\
\text { ivarszervek } \\
\text { kifejlett } \\
\text { állatokban }\end{array}$} \\
\hline & & & $\%$ & átlag & $\%$ & átlag & $\%$ & átlag & $\%$ & átlag & & $\%$ & átlag & $\%$ \\
\hline \multirow{4}{*}{ zpg } & 1.1 & 39 & 41.0 & \multirow{4}{*}{21.4} & 0.0 & \multirow{4}{*}{5.1} & 28.2 & \multirow{4}{*}{19.4} & 12.8 & \multirow{4}{*}{3.8} & 15.4 & \multirow{4}{*}{9.5} & 13.6 & \multirow{4}{*}{19.3} \\
\hline & 1.2 & 43 & 9.3 & & 11.6 & & 7.0 & & 0.0 & & 4.7 & & 9.3 & \\
\hline & 2.1 & 39 & 20.5 & & 0.0 & & 12.8 & & 2.6 & & 17.9 & & 16.7 & \\
\hline & 2.2 & 34 & 14.7 & & 8.8 & & 29.4 & & 0.0 & & 0.0 & & 37.5 & \\
\hline \multirow{3}{*}{ pgc } & 1.1 & 34 & 44.1 & \multirow{3}{*}{30.3} & 0.0 & \multirow{3}{*}{4.8} & 0.0 & \multirow{3}{*}{1.5} & 55.9 & \multirow{3}{*}{36.8} & 0.0 & \multirow{3}{*}{1.2} & 64.7 & \multirow{3}{*}{50.4} \\
\hline & 1.2 & 37 & 27.0 & & 10.8 & & 2.7 & & 18.9 & & 0.0 & & 42.3 & \\
\hline & 2.1 & 56 & 19.6 & & 3.6 & & 1.8 & & 35.7 & & 3.6 & & 44.1 & \\
\hline \multirow{3}{*}{ nos } & 1.1 & 43 & 32.6 & \multirow{3}{*}{25.0} & 7.0 & \multirow{3}{*}{9.4} & 2.3 & \multirow{3}{*}{3.4} & 32.6 & \multirow{3}{*}{35.1} & 4.7 & \multirow{3}{*}{3.9} & 21.1 & \multirow{3}{*}{30.9} \\
\hline & 1.2 & 23 & 17.4 & & 8.7 & & 4.3 & & 56.5 & & 0.0 & & 0.0 & \\
\hline & 2.1 & 56 & 25.0 & & 12.5 & & 3.6 & & 16.1 & & 7.1 & & 71.7 & \\
\hline \multirow{3}{*}{ mei-P26 } & 1.1 & 47 & 40.4 & & 0.0 & & 2.1 & & 2.1 & & 2.1 & & 34.3 & \\
\hline & 1.2 & 49 & 10.2 & 21.3 & 0.0 & 1.1 & 4.1 & 5.4 & 0.0 & 0.7 & 0.0 & 0.7 & 47.6 & 40.9 \\
\hline & 2.1 & 60 & 13.3 & & 3.3 & & 10.0 & & 0.0 & & 0.0 & & 40.9 & \\
\hline & 1.1 & 34 & 2.9 & & 2.9 & & 5.9 & & 58.8 & & 58.8 & & 50.0 & \\
\hline Tre1 & 1.2 & 48 & 10.4 & 5.5 & 6.3 & 3.1 & 8.3 & 5.3 & 45.8 & 56.4 & 45.8 & 57.5 & 4.2 & 38.7 \\
\hline & 2.1 & 62 & 3.2 & & 0.0 & & 1.6 & & 64.5 & & 67.7 & & 62.0 & \\
\hline & 1.1 & 32 & 3.1 & & 6.3 & & 12.5 & & 3.1 & & 9.4 & & 10.0 & \\
\hline CG7271 & 1.2 & 45 & 11.1 & 6.2 & 4.4 & 8.0 & 2.2 & 12.3 & 2.2 & 4.0 & 6.7 & 6.8 & 3.6 & 6.8 \\
\hline & 2.1 & 45 & 4.4 & & 13.3 & & 22.2 & & 6.7 & & 4.4 & & 0.0 & \\
\hline
\end{tabular}

Függelék 3. Táblázat: A géncsendesítési kísérletsorozat eredménye. A táblázatban a független kísérletek során a különböző embrionális ivarsejt fenotípusok és a kifejlett állatokban azonosított csökevényes ivarszerv fenotípusok előfordulási gyakoriságai (penetrancia értékei) vannak feltüntetve génenként százalékban kifejezve (\%). A táblázatban csak a reprodukálható fenotípust adó gének vannak megjelenítve (a géncsendesítési kísérletsorozat 48 jelölt génje). A gének csendesítésével előállított, ismételhető fenotípusok sárga háttérrel vannak jelölve. Az 1.1 és 1.2 kísérleteket a Heidelberg2 RNAi gyüjtemény dsRNS-eivel, míg a 2.1 és 2.2 kísérletek az általunk tervezett és szintetizált dsRNS-ek injektálásával végeztük. 


\begin{tabular}{|c|c|c|c|c|c|c|c|c|c|c|c|c|c|}
\hline \multirow{2}{*}{$\begin{array}{c}\text { Forrás } \\
\text { e. stádium }\end{array}$} & \multicolumn{6}{|c|}{ FlyFISH } & \multicolumn{6}{|c|}{ BDGP } & \multirow{2}{*}{\begin{tabular}{|l} 
CDNS \\
$13-17$
\end{tabular}} \\
\hline & $1-3$ & $1-3$ & 4-5 & $4-5$ & $6-7$ & 8-9 & $1-3$ & $4-6$ & $7-8$ & $9-10$ & $11-12$ & $13-16$ & \\
\hline Gén & 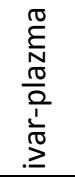 & 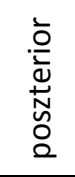 & 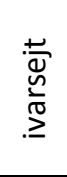 & 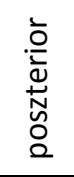 & 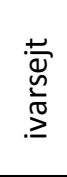 & 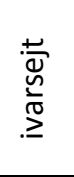 & 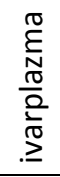 & 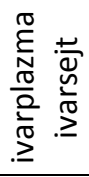 & 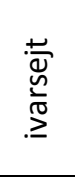 & 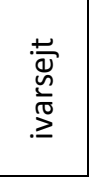 & 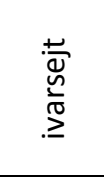 & 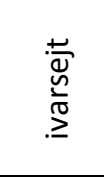 & 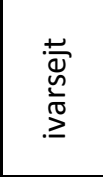 \\
\hline ade2 & - & - & - & - & - & - & - & - & - & + & + & - & - \\
\hline Aos1 & - & - & - & - & - & - & - & - & - & - & - & + & + \\
\hline bel & - & - & - & - & - & - & - & + & + & - & - & - & - \\
\hline Bsg25D & + & + & + & + & + & + & + & - & + & + & + & + & - \\
\hline casp & - & - & + & + & - & - & - & - & - & - & - & - & - \\
\hline CG13298 & - & - & - & - & - & - & - & - & - & - & - & + & - \\
\hline CG14438 & - & - & - & + & - & - & - & - & - & - & - & - & - \\
\hline CG14545 & - & - & - & - & - & - & - & - & - & + & + & + & - \\
\hline CG14838 & - & - & + & - & - & - & - & - & - & - & - & + & - \\
\hline CG17658 & - & - & - & - & - & - & - & + & + & + & + & - & - \\
\hline CG4281 & - & - & - & - & - & - & - & - & - & - & - & + & - \\
\hline CG7271/term & - & - & + & + & + & - & - & + & + & + & + & - & - \\
\hline CG8116 & - & - & + & + & + & + & - & - & - & - & - & - & - \\
\hline $\mathrm{crq}$ & - & - & - & - & - & - & - & + & + & + & - & - & - \\
\hline СусA & - & - & - & + & - & - & - & - & - & - & - & - & - \\
\hline CycB & + & + & + & + & + & - & - & - & - & - & - & - & - \\
\hline dnc & + & + & + & + & + & + & - & - & - & - & - & - & - \\
\hline$d s x$ & - & - & - & - & - & - & - & - & - & - & - & + & - \\
\hline elF5 & + & + & + & + & + & + & - & - & + & + & + & - & - \\
\hline feo & - & - & - & - & - & - & - & + & - & - & - & - & - \\
\hline $\mathrm{Fs}(2) \mathrm{Ket}$ & - & - & - & - & - & - & - & - & - & - & - & - & + \\
\hline hang & + & + & + & + & + & - & + & + & - & - & - & - & - \\
\hline Klp10A & - & - & - & + & - & - & - & - & - & - & - & - & - \\
\hline Klp61F & - & - & - & - & - & - & - & - & - & - & - & + & - \\
\hline $\mathrm{knrl}$ & - & - & - & - & - & - & - & - & - & - & - & + & - \\
\hline mael & - & - & + & + & + & - & - & - & + & + & + & + & - \\
\hline $\mathrm{mbc}$ & - & - & - & - & - & - & + & + & + & - & - & - & - \\
\hline mei-P26 & - & - & - & - & - & - & + & + & - & - & - & - & - \\
\hline Men & - & - & + & + & + & + & - & + & - & - & - & - & - \\
\hline $\mathrm{nclb}$ & - & - & - & - & - & - & - & - & - & - & - & + & - \\
\hline neur & - & - & - & - & - & - & - & - & - & - & + & + & - \\
\hline nos & + & + & + & + & + & + & - & - & - & - & - & - & - \\
\hline orb & + & + & + & + & + & - & - & - & - & - & - & - & - \\
\hline ovo & - & - & - & - & - & - & - & - & - & - & - & + & + \\
\hline $\mathrm{pbl}$ & + & + & + & + & + & + & - & - & - & - & - & - & - \\
\hline pgc & - & - & - & - & - & - & - & + & - & + & + & + & - \\
\hline Pglym78 & - & - & - & - & - & - & + & + & + & + & + & + & - \\
\hline Phf7 & - & - & - & - & - & - & - & - & - & - & - & + & - \\
\hline porin & - & - & - & + & - & - & - & - & - & - & - & - & - \\
\hline Reph & - & - & + & + & - & + & + & + & + & - & - & - & - \\
\hline
\end{tabular}




\begin{tabular}{|c|c|c|c|c|c|c|c|c|c|c|c|c|c|}
\hline Forrás & \multicolumn{6}{|c|}{ FlyFISH } & \multicolumn{6}{|c|}{ BDGP } & cDNS \\
\hline e. stádium & $1-3$ & $1-3$ & $4-5$ & $4-5$ & $6-7$ & $8-9$ & $1-3$ & $4-6$ & $7-8$ & $9-10$ & $11-12$ & $13-16$ & $13-16$ \\
\hline Gén & 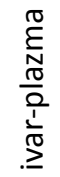 & 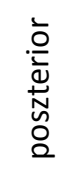 & 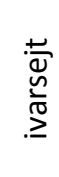 & 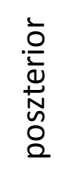 & 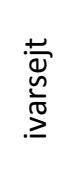 & 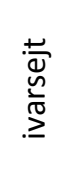 & 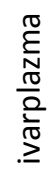 & 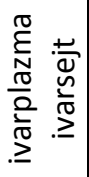 & 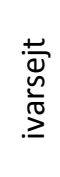 & 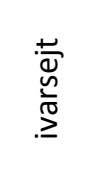 & 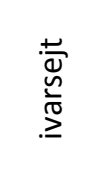 & 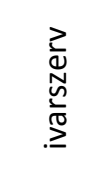 & 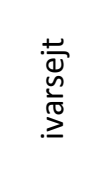 \\
\hline scra & - & - & - & + & - & - & - & - & - & - & - & - & + \\
\hline spir & + & + & + & + & - & - & + & + & - & - & - & - & - \\
\hline Su(var)205 & - & - & - & - & - & - & - & - & - & - & - & + & - \\
\hline Su(var)2-10 & - & - & + & + & - & - & - & - & - & - & - & - & - \\
\hline SuUR & + & + & + & + & + & - & + & - & - & - & - & - & - \\
\hline Thiolase & - & - & - & - & - & - & - & + & + & + & - & - & - \\
\hline Tre1 & - & - & + & + & + & - & + & + & + & + & + & + & - \\
\hline zpg & - & - & - & - & - & - & + & + & - & + & + & + & + \\
\hline
\end{tabular}

Függelék 4. táblázat: A géncsendesítő kísérletsorozat jelölt génjeinek expressziós mintázata az embrionális ivarvonalban. A táblázat a FlyFISH adatbázis (http://flyfish.ccbr.utoronto.ca) BDGP Drosophila embriók génexpressziós mintázatok adabázisából (http://fruitfly.org/cgi-bin/ex/insitu.pl), és Shigenobu és mtsai. munkája [54] alapján készült. A + jel azt jelzi, hogy az adott gén az embrionális fejlődés melyik stádiumában (e. stádium) fejeződik ki az ivarplazmában, az embrionális ivarsejtekben vagy ivarszervben. 


\begin{tabular}{|c|c|c|c|c|c|c|c|c|c|}
\hline \multirow{3}{*}{ Célgén } & \multirow{3}{*}{$\begin{array}{c}\text { Törzs- } \\
\text { azonosító }\end{array}$} & \multicolumn{4}{|c|}{$\mathrm{F}_{1}$} & \multicolumn{4}{|c|}{$F_{2}$} \\
\hline & & \multicolumn{2}{|c|}{ q } & \multicolumn{2}{|c|}{ o } & \multicolumn{2}{|c|}{ q } & \multicolumn{2}{|c|}{0} \\
\hline & & $\mathrm{n}$ & $\%$ & $\mathrm{n}$ & $\%$ & $\mathrm{n}$ & $\%$ & $\mathrm{n}$ & $\%$ \\
\hline ade2 & 36686 & 30 & 3.3 & 30 & 0.0 & 22 & 20.0 & 25 & 0.0 \\
\hline Aos1 & 36074 & 39 & 100.0 & 28 & 100.0 & $\mathrm{~S}$ & $S$ & $\mathrm{~S}$ & $S$ \\
\hline bel & 35185 & 30 & 100.0 & 27 & 100.0 & $\mathrm{~S}$ & $\mathrm{~S}$ & $\mathrm{~S}$ & $\mathrm{~S}$ \\
\hline bel & 35302 & 50 & 2.0 & 42 & 0.0 & 30 & 0.0 & 31 & 0.0 \\
\hline Bsg25D & 36828 & 30 & 0.0 & 29 & 3.4 & 30 & 0.0 & 23 & 0.0 \\
\hline CG13298 & 36619 & 30 & 100.0 & 30 & 100.0 & $\mathrm{~S}$ & $\mathrm{~S}$ & $\mathrm{~S}$ & $S$ \\
\hline CG13298 & 42873 & 30 & 100.0 & 30 & 100.0 & $\mathrm{~S}$ & $\mathrm{~S}$ & $\mathrm{~S}$ & $\mathrm{~S}$ \\
\hline CG14545 & 35625 & 31 & 0.0 & 26 & 0.0 & 30 & 0.0 & 30 & 0.0 \\
\hline CG17658 & 35661 & 35 & 0.0 & 30 & 0.0 & 30 & 0.0 & 30 & 0.0 \\
\hline CG17658 & 36772 & 24 & 4.2 & 11 & 0.0 & n.a. & n.a. & n.a. & n.a. \\
\hline CG4281 & 35685 & 35 & 100.0 & 26 & 100.0 & $\mathrm{~S}$ & $\mathrm{~S}$ & $\mathrm{~S}$ & $\mathrm{~S}$ \\
\hline CG4281 & 41890 & 30 & 0.0 & 30 & 0.0 & 30 & 0.0 & 30 & 0.0 \\
\hline CG6543 & 36813 & 30 & 3.3 & 31 & 6.5 & 30 & 0.0 & 11 & 0.0 \\
\hline CG6751 & 41826 & 30 & 100.0 & 26 & 100.0 & $\mathrm{~S}$ & $\mathrm{~S}$ & $\mathrm{~S}$ & $\mathrm{~S}$ \\
\hline CG7271 & 41822 & 34 & 4.4 & 30 & 0.0 & 30 & 0.0 & 21 & 0.0 \\
\hline CG8116 & 36837 & 30 & 100.0 & 23 & 8.7 & $\mathrm{~S}$ & $\mathrm{~S}$ & $\mathrm{~S}$ & $\mathrm{~S}$ \\
\hline crq & 40831 & 30 & 0.0 & 30 & 0.0 & 18 & 0.0 & 20 & 0.0 \\
\hline СусA & 35694 & 48 & 97.9 & 29 & 96.6 & $\mathrm{~s}$ & $\mathrm{~S}$ & $\mathrm{~S}$ & $\mathrm{~S}$ \\
\hline CyсB & 34544 & 39 & 56.4 & 19 & 0.0 & $\mathrm{~S}$ & $\mathrm{~S}$ & $\mathrm{~S}$ & $\mathrm{~S}$ \\
\hline CyсB & 38979 & 18 & 27.8 & 22 & 31.8 & n.a. & n.a. & n.a. & n.a. \\
\hline CycB & 38980 & 35 & 77.1 & 15 & 23.3 & 8 & 0.0 & 9 & 0.0 \\
\hline CycB & 38981 & 31 & 0.0 & 30 & 0.0 & 30 & 0.0 & 14 & 0.0 \\
\hline CycB & 39023 & 30 & 0.0 & 19 & 0.0 & 31 & 0.0 & 8 & 0.0 \\
\hline CycB & 39024 & 31 & 3.2 & 34 & 0.0 & 30 & 0.0 & 18 & 0.0 \\
\hline dnc & 41644 & 19 & 0.0 & 18 & 0.0 & 27 & 7.4 & 9 & 22.2 \\
\hline$d s x$ & 35645 & 32 & 0.0 & 28 & 0.0 & 32 & 47.9 & 28 & 0.0 \\
\hline dsx 2 & 41864 & 13 & 0.0 & 11 & 0.0 & 25 & 0.0 & 24 & 0.0 \\
\hline elF5 & 34841 & 31 & 100.0 & 28 & 100.0 & $\mathrm{~S}$ & $S$ & $\mathrm{~S}$ & $S$ \\
\hline feo & 35467 & 41 & 100.0 & 27 & 0.0 & $\mathrm{~S}$ & $\mathrm{~S}$ & $\mathrm{~S}$ & $\mathrm{~S}$ \\
\hline $\mathrm{Fs}(2) \mathrm{Ket}$ & 41845 & 22 & 0.0 & 32 & 100.0 & $\mathrm{~S}$ & $\mathrm{~S}$ & $\mathrm{~S}$ & $\mathrm{~S}$ \\
\hline hang & 35674 & 35 & 1.4 & 27 & 1.9 & 24 & 2.1 & 17 & 0.0 \\
\hline hang & 41870 & 30 & 100.0 & 28 & 0.0 & $\mathrm{~S}$ & $S$ & $\mathrm{~S}$ & $S$ \\
\hline Klp10A & 33963 & 31 & 0.0 & 30 & 0.0 & n.a. & n.a. & n.a. & n.a. \\
\hline Klp61F & 33685 & 69 & 100.0 & 81 & 100.0 & $\mathrm{~S}$ & $\mathrm{~S}$ & $\mathrm{~S}$ & $S$ \\
\hline Klp61F & 35804 & 30 & 100.0 & 18 & 100.0 & $\mathrm{~S}$ & $\mathrm{~S}$ & $\mathrm{~S}$ & $\mathrm{~S}$ \\
\hline knrl & 36664 & 30 & 0.0 & 30 & 3.3 & 30 & 0.0 & 17 & 0.0 \\
\hline mael & 34793 & 33 & 100.0 & 21 & 0.0 & $S$ & $S$ & $\mathrm{~S}$ & $S$ \\
\hline mael & 35202 & 30 & 0.0 & 21 & 2.4 & 23 & 0.0 & 15 & 0.0 \\
\hline$m b c$ & 33722 & 33 & 0.0 & 12 & 0.0 & 30 & 0.0 & 3 & 0.0 \\
\hline $\mathrm{mbc}$ & 32355 & 35 & 0.0 & 27 & 0.0 & 31 & 0.0 & 17 & 0.0 \\
\hline $\mathrm{mbc}$ & 44424 & 30 & 3.3 & 19 & 5.3 & 36 & 0.0 & 19 & 0.0 \\
\hline mei-P26 & 36855 & 38 & 43.4 & 18 & 0.0 & $\mathrm{~S}$ & $S$ & $\mathrm{~S}$ & $S$ \\
\hline Men & 38256 & 26 & 0.0 & 30 & 0.0 & 28 & 0.0 & 8 & 6.2 \\
\hline Men & 41652 & 30 & 0.0 & 17 & 0.0 & n.a. & n.a. & n.a. & n.a. \\
\hline neur & 35412 & 30 & 0.0 & 14 & 0.0 & 30 & 0.0 & 27 & 0.0 \\
\hline
\end{tabular}




\begin{tabular}{|c|c|c|c|c|c|c|c|c|c|}
\hline \multirow{3}{*}{ Célgén } & \multirow{3}{*}{$\begin{array}{c}\text { Törzs- } \\
\text { azonosító }\end{array}$} & \multicolumn{4}{|c|}{$\mathrm{F}_{1}$} & \multicolumn{4}{|c|}{$\mathrm{F}_{2}$} \\
\hline & & \multicolumn{2}{|c|}{ q } & \multicolumn{2}{|c|}{ 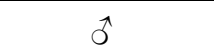 } & \multicolumn{2}{|c|}{ q } & \multicolumn{2}{|c|}{$\hat{0}$} \\
\hline & & $\mathbf{n}$ & $\%$ & $\mathbf{n}$ & $\%$ & $\mathbf{n}$ & $\%$ & $\mathbf{n}$ & $\%$ \\
\hline nos & 32985 & 31 & 3.2 & 22 & 0.0 & 30 & 0.0 & 13 & 0.0 \\
\hline nos & 33973 & 54 & 1.9 & 47 & 1.1 & 45 & 33.3 & 12 & 0.0 \\
\hline orb & 43143 & 30 & 100.0 & 30 & 0.0 & $\mathrm{~S}$ & $\mathrm{~S}$ & $S$ & $S$ \\
\hline ovo & 35413 & 31 & 1.6 & 23 & 0.0 & 30 & 0.0 & 30 & 0.0 \\
\hline ovo & 42627 & 30 & 0.0 & 29 & 0.0 & 30 & 0.0 & 30 & 0.0 \\
\hline $\mathrm{pbl}$ & 36841 & 30 & 100.0 & 30 & 100.0 & $\mathrm{~S}$ & $\mathrm{~S}$ & $\mathrm{~S}$ & $\mathrm{~S}$ \\
\hline $\mathrm{pbl}$ & 28343 & 30 & 70.0 & 30 & 3.3 & $S$ & $S$ & $S$ & $S$ \\
\hline pgc & 33720 & 28 & 0.0 & 24 & 0.0 & 30 & 0.0 & 17 & 0.0 \\
\hline pgc & 32386 & 39 & 1.3 & 16 & 0.0 & 34 & 4.1 & 11 & 0.0 \\
\hline Pglym78 & 41603 & 21 & 0.0 & 8 & 0.0 & 24 & 0.0 & 14 & 0.0 \\
\hline Phf7 & 35807 & 41 & 0.0 & 30 & 0.0 & 30 & 0.0 & 30 & 0.0 \\
\hline Reph & 41658 & 25 & 2.0 & 8 & 0.0 & 27 & 0.0 & 11 & 0.0 \\
\hline scra & 41841 & 35 & 100.0 & 12 & 0.0 & $S$ & $\mathrm{~S}$ & $S$ & $S$ \\
\hline spir & 43161 & 30 & 0.0 & 30 & 0.0 & 32 & 100.0 & 29 & 100.0 \\
\hline Su(var)205 & 33400 & 31 & 96.8 & 30 & 0.0 & $S$ & $\mathrm{~S}$ & $S$ & $\mathrm{~S}$ \\
\hline Su(var)205 & 36792 & 27 & 5.6 & 20 & 0.0 & n.a. & n.a. & n.a. & n.a. \\
\hline Su(var)2-10 & 32915 & 22 & 100.0 & 11 & 100.0 & $S$ & $S$ & $\mathrm{~S}$ & $S$ \\
\hline Su(var)2-10 & 32956 & 30 & 100.0 & 25 & 100.0 & $\mathrm{~S}$ & $\mathrm{~S}$ & $S$ & $S$ \\
\hline SuUR & 36893 & 30 & 0.0 & 30 & 0.0 & 21 & 0.0 & 8 & 0.0 \\
\hline CG7271/term & 35681 & 34 & 0.0 & 26 & 100.0 & 30 & 0.0 & 23 & 0.0 \\
\hline CG7271/term & 42921 & 30 & 0.0 & 30 & 0.0 & 33 & 0.0 & 25 & 0.0 \\
\hline Thiolase & 34546 & 38 & 0.0 & 28 & 1.8 & 30 & 0.0 & 29 & 0.0 \\
\hline Tre1 & 33718 & 30 & 0.0 & 30 & 0.0 & 34 & 48.5 & 26 & 63.5 \\
\hline Tre1 & 34956 & 30 & 0.0 & 23 & 0.0 & 30 & 0.0 & 29 & 0.0 \\
\hline Tre1 & 38925 & 21 & 2.4 & 11 & 0.0 & 30 & 91.6 & 29 & 89.7 \\
\hline zpg & 35607 & 35 & 94.3 & 26 & 100.0 & $\mathrm{~S}$ & $\mathrm{~S}$ & $\mathrm{~S}$ & $\mathrm{~S}$ \\
\hline eGFP (kontrol) & 35782 & 30 & 0.0 & 30 & 0.0 & 30 & 0.0 & 30 & 0.0 \\
\hline
\end{tabular}

Függelék 5. táblázat: A géncsendesítési kísérletsorozat jelölt génjeinek ivarvonalspecifikus csendesítésének eredménye. A kísérletben nos-GAL4-VP16 GAL4-forrást hordozó szüz nőstényeket kereszteztünk a célgénre specifikus UAS-shRNS-t hordozó hímekkel. A GAL4-forrást és az UAS- shRNS transzgént hordózó, kifejlett egyedeket felboncoltuk ( $F_{1}$ nemzedék), megállapítottuk, hogy a nőstényekben és hímekben milyen arányban fordulnak elő a csökevényes ivarszervek. Amennyiben a nőstények ne mutattak csökevényes ivarszerv fenotípust, vad típusú hímekkel kereszteztük őket, teszteltük fertilításukat, és amennyiben fertilisek voltak, utódaikban (F2 nemzedék) és ismét megállapítottuk a csökevényes ivarszervek penetranciáját. Rövidítések: n: felboncolt állatok száma; n.a.: nincs adat; S: F1 nöstény steril, nem rak petéket, vagy a peték elpusztulnak. 


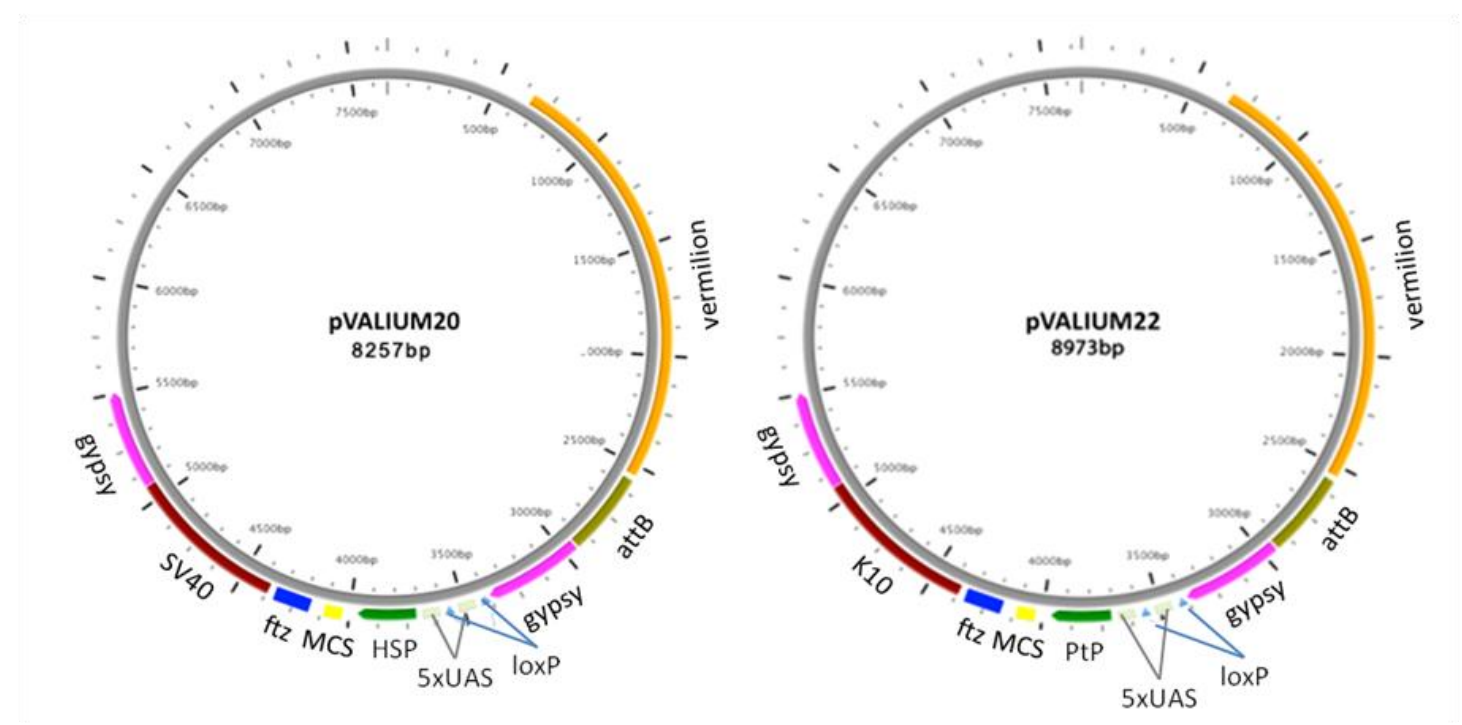

Függelék 1. ábra: Ivarvonal-specifikus shRNS transzgén kifejezésre alkalmas vektorok:

VALIUM20 és VALIUM22. A miR-1 mikroRNS alapú shRNS-ek transzgenikus expresszíóát a Drosophila ivarvonalban a második generációs VALIUM (V20, V22) vektorok segítségével oldható meg. Mindhárom plazmid tartalmaz szemszín markergént (vermilion), mely a transzformánsok azonosítását teszi lehetővé. Az attB hely lehetővé teszi, hogy a vektor $\Phi 31 \mathrm{C}$ rekombináz segítségével a recipiens Drosophila genom attB landolóhelyére épüljön be. Szintén mindhárom plazmid sajátsága a kétszer öt GAL4 kötő UAS enhanszer, melyek egyik csoportját loxP helyek veszik körül. Cre rekombináz segítségével, az enzim célszekvenciái (loxP helyek) közötti 5xUAS szekvencia kivágható, így a transzgén kifejeződés csökkenthető. Az MCS rövidítés a poliklónozó helyet jelöli, ahová a miRNS ligálható. A V20 plazmid Hsp70 (HSP) promótert és SV40 poliadenilációs jelet tartalmaz, míg a V22 esetében P-transzpozon promóterek (PtP) és K10 poliadenilációs helyek segítik a transzgén kifejeződést az ivarvonalban. Az ftz jelölés a fushi-tarazu gén 3'UTR intronját jelöli, mely segíti az RNS magi exportját. A gypsy határoló elemeknek a transzgén kifejezödésének genomi környezettől való elszigetelésében van jelentősége. A VALIUM20 vektort eredetileg testi sejtekben történő, míg a VALIUM22 vektort kimondottan ivarvonal-specifikus transzgén kifejeztetésre tervezték. 